


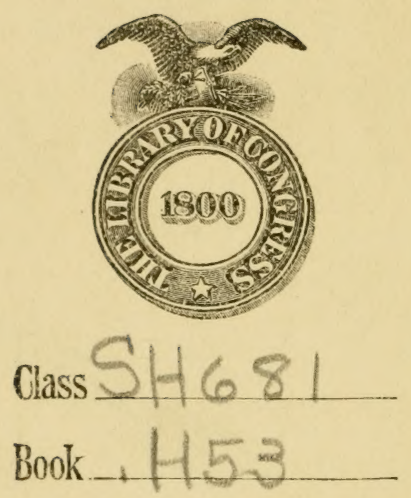

Copyight No.

COPXRIGHT DEPOSK. 





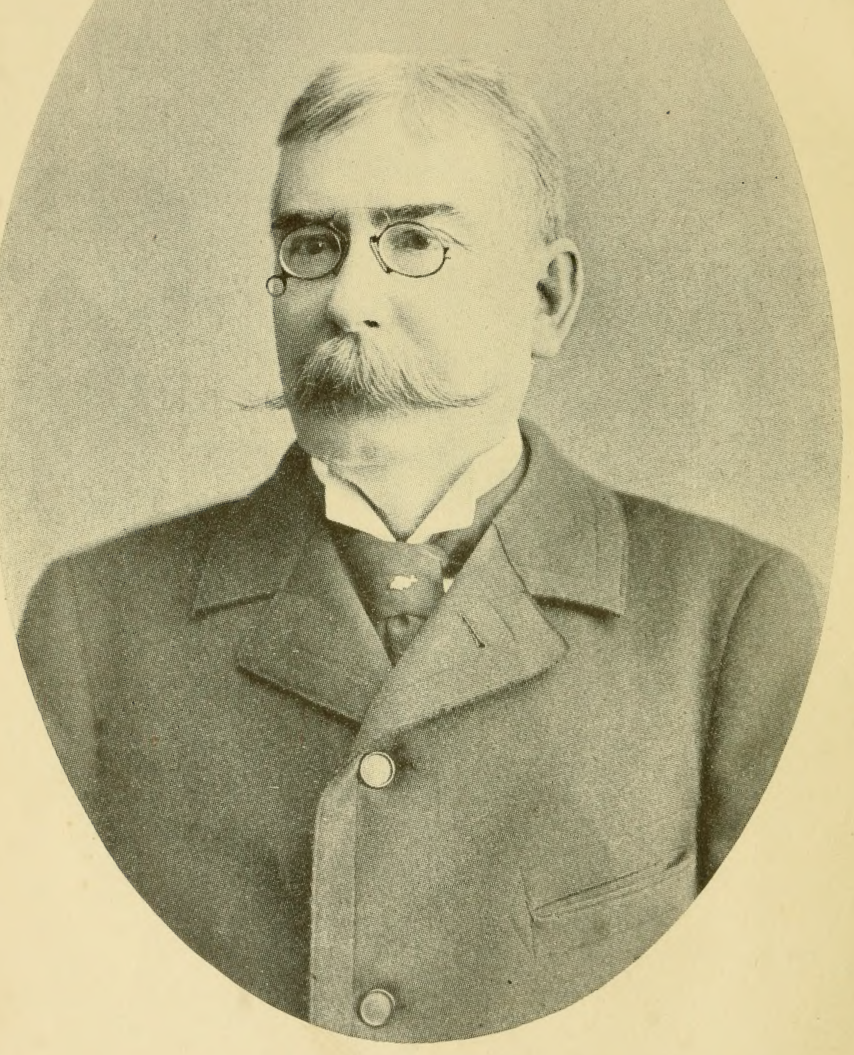

Youns truly,

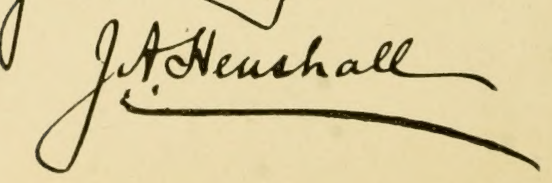




\section{BOOK of the BLACK BASS}

By James A. Henshall, M. D.

AUTHOR OF! "CAMPING AND CRUISING IN FLORIDA," "YE GODS AND LITTLE FISHES," "BASS, PIKE, PERCH AND OTHERS," ETC.

\section{FULLY ILLUSTRATED}

\section{NEW EDITION \\ REVISED AND EXTENDED}

CINCINNATI

THE ROBERT CLARKE COMPANY 1904 
$5 H^{6^{8}} H^{5^{3}}$

Copyright $A 89095$

Copyright, I88I,

By J. A. HENSHALL

COPYRIGHT, I9O4,

By THE ROBERT CLARKE COMPANY 


\section{PREFACE.}

This edition of the Book of the Black Bass includes also the Supplement, More About the Black Bass, and is complete in one volume. A new edition of these books has been necessitated owing to the destruction by fire of the stereotype plates of the former editions. Advantage was taken of this circumstance for a thorough revision, whereby much of the text of the old editions has been eliminated, new matter substituted, and other features added more in accordance with the present knowledge of the subject.

The first edition of this book owed its origin to a long-cherished desire on the part of the author to give to the black bass species their proper place among gamefishes, and to create among anglers, and the public generally, an interest in two fishes that had never been so fully appreciated as their merits deserved, because of the want of suitable tackle for their capture, on the one hand, and a lack of information regarding their habits and economic value on the other. At the present day, however, the author's prediction that they would eventually become the favorite game-fish of America has been fully verified.

The "Book of the Black Bass" is of an entirely practical nature regarding its subject-matter and its illustrations. It has been written more with a view to instruct than to amuse or entertain. The reader will, therefore, look in vain between its covers for those 
rhetorical flights, poetic descriptions, entertaining accounts and pleasing illustrations of the pleasures and vicissitudes of angling, which are usually found in works of like character.

In addition to the scientific and life history of both species of black bass, it gives a practical treatise on angling and fly-fishing, and a full description of all tools and tackle employed for their capture.

I am under obligation to the Century Company for the illustrations of "Landing a Double" and the "Still Fisher." I was desirous to use the former inasmuch as it was originally drawn to illustrate one of my articles on black bass fishing, and my friend, the late Prof. Alfred M. Mayer posed for the drawing. I also extend my thanks to G. F. Corner for the sketch of the "Old Kentucky Angler."

It is as well to say that the last addition to the subject that I intended to make was the supplement "More About the Black Bass;" the credit is due, therefore, to The Robert Clarke Company for this new edition of my book, which has risen, phønix-like, from the ashes of the former one.

Bozeman, Montana, Aprit, 1904. 


\section{CONTENTS.}

PART FIRST.

CHAPTER.

SCIENTIFIC AND LIFE HISTORY.

I. Scientific History of the Black Bass........... 3

II. Nomenclature ANd Morphology............. 26

III. General and Spectal Features of the Black Bass. 45

IV. Coloration of the Black Bass ............. 53

V. Geographical Distribution of the Black Bass.. 64

VI. Habits of the Blick B.ss. Spawning, Hatehing, ete. $7 t$

VII. Ixtelligexce axd Specill Sexses. Sight, Hearing. 92

Vill. Stocking Waters with Black Bass.......... 111

\section{PART SECOND.}

\section{TOOLS, TACKLE AND IMPLENENTS.}

IX. Fishing Rods. Fly-rods, Bait-rods, ete........ 127

X. Frshixg Reers. ('lick Reels, Multiplying Reels, ete. 1it

XI. Fishing Lines. Fly Lines, Bait Lines, etc....... 205

XII. Silk-IVorir Gut. Leaders, Snells, etc...........216

XIII. Fisir Hoors. Sproat, O'Shaughnessy, Limerick, etc. 230

XIV. Artificial Flies. Winged Flies, Hackles, etc.... 243

XV. Artifictal Barts. Trolling-Spoons, Casting-Spoons. 2is

XVI. Natural Baits. Minnows, Frogs, Crawfish, etc.... 268 XVII. Mincelhaneors Implements. Fly-Books, Creels, etc. 276

\section{PART THIRD.}

\section{ANGLING AND FLY FISHING.}

XVIII. The Philosophi of Angling................ 307

XiX. Conditions Governing tire Biting of Fism....... 316

XX. The Black Bass as a Game Fish ............. 338

XXI. Fly Fisming. Tackle, Casting, Instructions, etc ... 357

XXII. Bait Fisming. Tackle, Casting, Instructions, etc... 385

XXIII. Strlu Fishing. Tackle, Baits, Instructions, etc.... 411

XIV. Trolling. Tackle, General Instructions, etc...... 420

XXV. Skittering Ann BobBing. Tackle. Instructions, etc. 428 XXVI. Concluding Remairs. Care of Tackle, Advice, etc. 433 [v] 



\section{PART I.}

SCIENTIFIC AND LIFE HISTORY. 



\title{
BOOK OF THE BLACK BASS.
}

\author{
CHAPTER I. \\ SCIENTIFIC HISTORY OF THE BLACK BASS.*
}

(Micropterus.)

"For my name and memory, I leave it to men's charitable speeches, to foreign nations, and to the next ages."-BAcox.

THE scientific history of the black bass is a most unsatisfactory one. This is owing to a train of accidental circumstances, and to the neglect of thorough investigation of its earliest history, as recorded by Lacépède, the renowned French naturalist, in the original edition of his great work, "Histoire Naturelle des Poissons."

This representative American fish was first brought to the light of science in a foreign land, and under the most unfavorable auspices. Its scientific birth was, like Macduff's, untimely; it was, unhappily, born a monstrosity;

* In the first edition of this book an exhaustive review of the nomenclature and morphology of the black bass species was given, introducing a number of lengthy papers and references bearing on the subject. In the present edition the author deems it unnecessary to reproduce much of the evidence then used to prove and corroborate his arguments, inasmuch as his views have been fully concurred in, and his restoration of Lacépède's names for the two species has been indorsed and adopted. It is, therefore, deemed sufficient to present in a concise form, and in chronological order, the perplexing account of the nomenclature of the species from their first description by Lacépède to the final restoration of his generic and specific names. 
its baptismal names were, consequently, incongruous, and its sponsors were, most unfortunately, foreign naturalists.

Previous to the first edition of this book, in 1881, it had been considered by American naturalists that the first scientific description of a black bass was that published by Lacépède, about the year 1800, in the work just referred to. This description was founded upon a drawing of a black bass, and accompanying manuscript notes, sent to him by M. Bose, from the vicinity of Charleston, South (arolina, with the local name of "trout," or "troutperch."* This figure, and its accompanying description, were said to be so uncertain and inaccurate, that it had been considered very doubtful which species of black bass was intended to be represented. However, Lacépède namerl it Labrus salmoides (Labre salmoide) - the "trout-like" labrus, in accordance with its general appearance and vernacular name. The European genus Labrus embraces a great many species, and some American fishes were referred to it by European, as well as by our early American, naturalists.

It had also been held by American ichthyologists that it was after this, in 1801, that Lacépède received his first example of a black bass. This was a fine adult specimen

* Some forty years before M. Bose sent the drawing of the Carolina "trout" to Lacépède, two specimens of the same fish had been sent to Linnieus by Dr. Garden, of Charleston, S. C. These speeimens were pressed skins of one-half of the fish, retaining the vertical fins, and mounted in the same manner as botanical specimens. Linneus failed to deseribe or name them, but they are still preserved in the rooms of the Linnean Society in the Burlington ITouse, London, England, in connection with the Linnsan herharium and library. One of the examples is labeled thus by Dr. Garden: "No. 40. Labrus. Nostralib. Fresh-water Trout." 
of the small-mouth species, but, unfortunately, it was an abnormal specimen, with a deformed dorsal fin, several of the last rays having been apparently bitten off and tom loose from the others when the fish was young, presenting the appearance of a separate small fin. In conformity with this accidental peculiarity, Lacépède named it Mícropterus dolomieu - Dolomieu's "small-fin" — supposing that the little fin was a permanent and distinctive feature, and of generic value; he accordingly created the new genus Micropterus, and named the type in honor of his friend Dolomieu, a well-known French mineralogist, for whom the mineral dolomite was also named.*

In 181\%, C. S. Rafinesque, another French naturalist, then living in America, procured specimens, apparently of the small-mouth bass, in the region of Lake Champlain, which he named Bodianus achigan, from the Canadian rulgar name of l'achigan. He either failed to recognize, or repudiated, Lacépède's former descriptions of Labrus salmoides and Micropterus dolomieu. During the next few years, from 1818 to 1820 , while collecting in the Ohio River and its tributaries, in Kentucky, Rafinesque took and described specimens of the small-mouth black bass, at different stages of its growth, as Calliurus punctulatus, Lepomis trifasciata, Lepomis flexuolaris, Lepomis salmonea, Lepomis notata, and Etheostoma calliura, and specimens of the large-mouth bass he described as Lepomis pallida.

In 182., Charles A. Le Sueur, also a French naturalist, while in this country described and named specimens, of

* In 1887 I personally examined this specimen in the Museum of Natural History in the Jardin des Plantes at Paris. It is a fine example, about a foot in length, and is in a remarkably good state of preservation. It is undoubtedly a small-mouth black bass. 
various ages, of the small-mouth black bass, as Cichin variabilis, (this name was never published by Le Sueur, but specimens sent by him and thus labeled, are still prescrved in the Musem D'Histoire Naturelle at Paris,) ('ichla fasciale. C'ichla ohiensis and Cichla minima, and the large-mouth bass from Florida as Cichla floridana, thus dissenting from, or entirely ignoring, Rafinesque.

In 18:s. the great Cuvier and his coadjutor, Talenciennes. received from Lake IIuron a specimen of the largemouth black bass, and which, as in the case of the first -mall-mouth bass sent to France, was, curiously enough, an abnormal or mutilated specimen, having likewise a delormed dorsal fin. In this instance, the last two rays of the spinous dorsal fin were torn off, thus leaving, apparently, two seprate and distinct dorsal fins, the first composed of six spines, and the second of two spines and twelve or thirteen solt rays. This specimen was sent to them under the local name of "black bass," or "black perch;" and not suspecting the mutilation of the specimen. they named it Huro nigricans - the "black huron."

In the following year, 1829, Cuvier and Valenciennes olstained two specimens, through M. Milbert, of the largemouth bass, from New York, under the name of "growler," and four specimens of the small-mouth bass, through te Sueur, from the Wabash River, in Indiana, all of which they irlentified with Lacépède's Labrus salmoides, and Le Sueur's C'ichla reriabilis, and which they named Crystes sulmoides. Subsequently Cuvier and Talenciennes announcer that Isacéperde's Micropterus dolomieu was also identical with their Grystes salmoides.*

* These specimens I have also personally examined. The two examples sent to the museum at Paris by Milbert, and from one of 


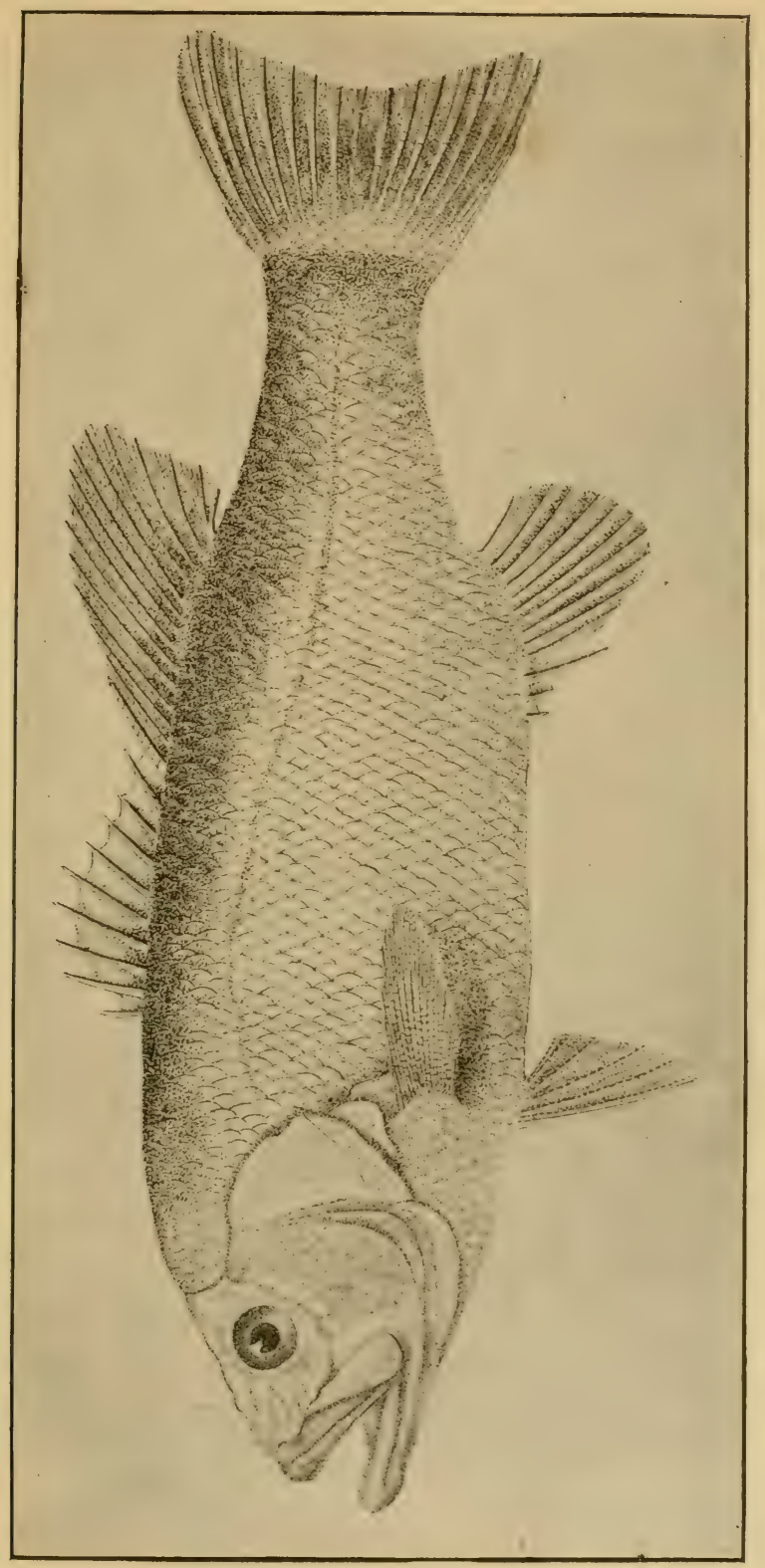

$\stackrel{203}{3}$

ن

$\Xi \vdots$

$\Rightarrow$

는

$>0$

$\Rightarrow$ ह 3

$>-\equiv$

5 की

की $\approx$

를

이

7 c c

₹

क छ

क इ

E

(2) $\Xi 10$

त)

다 छ

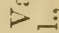

छ

它

$\Xi 0$

4 क क

पै

$\stackrel{0}{=} \cdot \frac{1}{0}$

छ

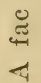


The complex species, Grystes salmoides, thus created by Curier, was the origin and beginning of most of the subsequent confusion that attended the nomenclature of the black bass species in America, inasmuch as he embraced both the large-mouth and small-mouth basses in this name.

In 1842, Dr. James E. DeKay, in his "Fishes of New York," after reproducing Cuvier and Talenciemnes' figures and descriptions of Huro nigricans and Grystes salmoides. described specimens of the small-mouth black bass under two additional names: Centrarchus fasciatus and Centrarchus obscurus, claiming the latter as a new species.

In the same year, Dr. Jared P. Kirtland adopted Centrarchus fasciatus as synonymous with Le Sueur's and Rafinesque's numerous descriptions of the small-mouth species.

In 1849, Dr. John E. Holbrook recorded the large-mouth bass as Grystes salmoides (name only) in a catalogue of fauna and flora in the "Statistics of Georgia." It will be noticed that Dr. Holbrook thus considered Grystes salmoides to be the proper name of the large-mouth black bass, or "trout," of Georgia.

In 1850, Prof. Louis Agassiz recognized the generic identity of the former descriptions of the black bass by Le Sueur, Cuvier and Valenciennes, and DeKay, and retained the name Grystes for the same.

In 1854, Prof. Agassiz obtained specimens of the largemouth bass from the Tennessee River, near Huntsville,

which the figure in Cuvier and Valenciennes" "Histoire Naturelle des Poissons" was taken, are both large-mouth black bass, one being fully eight, and the other about six inches in length. The four specimens from the Wabash River sent to the museum by Le Sueur are all small-mouth bass, the largest being at least fifteen inches in length, and the others about one-third as long. 
Ala., which he named, provisionally, Grystes nobilis. In the same year, Messrs. Baird and Girard deseribed specimens of the same species from T'exas, as Grystes nuecensis.

In 1855, in his "Ichthyology of South Carolina," Dr. Iollorook gave an excellent figure and the first full and claborate description of the Carolina "trout," under the name of Grystes salmoides Lacépède.

In 185\%, 1)r. Theodatus Garlick, one of the fathers of fish culture in America, described the small-mouth black bass as Grystes nigricans, and the large-mouth species as Grystes megastoma.

In 1858, Dr. Charles Girard described the large-mouth hass as Dioptites nuecensis.

In 1860, Dr. Theo. Gill restored Rafinesque's earliest name for the small-mouth form of the black bass, calling it Lepomis achigan, which, however, he changed in 1865 to Micropterus achigan, and still later, in $18 \% 3$, he adopted Lacépède's name, Micropterus salmoides, for the same species.

In 1865, Dr. Edw. D. Cope named the large-mouth hass, Micropterus nigricans, which name was also adopted by Prof. Gill in 1866.

In $18 \% 1$, when, apparently, the oldest generic and specific names, Hicropterus salmoides for the small-mouth bass, and Mirropterus nigricans for the large-mouth bass, had been restored, as in Prof. Gill's masterly review* of the species in the previous rear (when the tangled wel) had heen, secmingly, straightened), when dry land was thought to have been reacherl at last; - then came the French natu-

* On the species of the genus Micropterus (Lac.) or Grystes (Auct.). By Theodore Gill, of Washington, D. C. Proceedings of the American Asiociation for the Advaneement of Science, xxir, 1873 , pp. B. 55-72. 
ralists, again. MII. Taillant and Bocourt, of Paris, instead of profiting by the experience of their predecessors in this matter, tried to show that we had four species of black hass, where but two really existed, and this in spite of the fact that the Gallic misnomer of the type species still existed as a terrible warning to them, of the folly of indulging their national love of novelty where so grave a matter as science was concerned. They proposed the title Dioplites variabilis for the small-mouth form, and Dioplites treculii, Dioplites nuecensis and Dioplites salmoides, for the large-mouth form, under sereral unimportant varietal, or individual, differences.

In 1s:6, Dr. G. Brown Goode restored Le Sueur's name, and called the large-mouth black bass Micropterus floridanus.

In 18\%\%, Dr. David S. Jordan restorer the still older name of Rafinesque for this species, and with the full concurrence of Dr. Theo. Gill, designated it Micropterus pallidus.

In 18\%8, Dr. Jordan divided the small-mouth species into two geographical varicties, distinguishing the Northern form as M. salmoides var. achigan, and the Southern form as $M$. salmoides var. salmoides.

Finally, MM. Taillant and Bocourt (Miss. Sci. au Mexique: ined.) adopted the generic title Micropterus, but recognized four provisional species: $M$. dolomieu and $M$. variabilis for the small-mouth form and 1 . salmoides and M. nuecensis for the large-mouth form. under certain, evidently, unimportant variations.

Thus, it will be seen that, from the first. the nomenclature of the black bass species had been involved in great doubt, uncertaintr, and confusion; and while much of the complexity had been, apparently, dissipated, there still 
existed among ichthyologists some difference of opinion as to the proper differentiation of the species. Even the generally accepted nomenclature, prior to 1881, unfortunately and unavoidably established, as it was, on an insecure basis, was liable at any time to fall to the ground while the said differences among the authorities existed.

Now, if we could have felt perfectly confident and reasonably sure that the premises adopted by our American naturalists were correct, to wit: that Labrus salmoides Lacépède was the first scientific description of the smallmouth bass, we could then have left the subject here, with the firm conviction that the matter was settled for all time. and could thus have felt assured of the ultimate and universal adoption and perpetuity of the American nomenclature of the black bass, viz: Micropterus salmoides (Lacépède) Gill, for the small-mouth species, and Micropterus pallidus (Rafinesque) Gill \& Jordan, for the large-mouth species. In that event, I say, we could have rested content; for, although the generic appellation, and the specific title of the small-mouth black bass, as proposed, were misnomers, they were the only names that could rightly be bestowed, under the circumstances, and we could well afford to submit gracefully to what could not be bettered, or helped.

It will he observed, however, that Dr. Vaillant proposed the title Micropterus sulmoides for the large-mouth bass; and as we called the small-mouth bass by the same name, it would have produced endless confusion were that state of things to continue. If the black bass of Europe were always to be confined to a few preserved specimens and plaster casts in the museums, it would not have mattered $\therefore$ much: hut as this desirable same-fish had been already introluced into European waters, it would seem to be a 
matter of some interest to obtain a correct, uniform, and universal nomenclature of the species. Even as late as 1880 Dr. Günther, the great English authority, in his "Introduction to the Study of Fishes," nailed Grystes and Huro to the mast-head as valid genera.

It will be noticed that Dr. Vaillant adopted the northern and southern varieties of the small-mouth bass as provisional species, and likewise separated the large-mouth bass into two species, one being distinguished by teeth on the tongue, the other by their absence. I have often noticed this peculiarity of the presence or absence of lingual teeth in the large-mouth species in fish from various waters, and am not sure but I have observed it in the smallmouth species occasionally, but I have always considered it as dereloped, possibly, by the character of the food in certain localities, or merely a phase of individual variation.

In 1878, Dr. Jordan, while in Europe, gave great attention to the investigation of the black bass from the Paris standpoint. He examined, with the greatest care, Lacépède's original type specimen, and the specimens of Curier: and Valenciennes. He was determined to get to the bottom of the matter, if possible, and to this end consulted freely, and compared notes, with the French ichthyologists, who aided him in every possible way. He afterward pulblishert the result of his researches, which forms one of the most interesting papers pertaining to the literature of the black bass.*

Dr. Jordan sulbmitted the eridence resulting from his investigation to Dr. Gill, who, owing to his faith in Cuvier,

* Notes on Certain Typical Specimens of American Fishes in the British Museum and in the Museum D'Histoire Naturelle at Paris. By David S. Jordan, M.D. < Proceedings of United States National Nuseum, II, 1879, pp. 218-226. 
and to a misleading reprint of Lacépède's Natural History of Fishes, concluded that we could still retain our nomenclature of the black bass species, viz: Micropterus salmoides for the small-mouth, and Micropterus pallidus for the largemouth, for reasons that it is not necessary to repeat here. This view was acquiesced in by Dr. Jordan, though he admitted in the paper referred to that "the specific name dolomieu was the first ever distinctly applied to our smallmouth black bass," and that in the figure of Bosc's Labrus sulmoides "the mouth is drawn large, and if we must choose, the large-mouth is best represented;" also that in the museum at Paris the name salmoides was fully adopted for that species.

I was convinced that the estimate of the black bass species as entertained by Dr. Vaillant was correct, and that dotomieu for the small-mouth, and sulmoides for the largemouth black bass, were more in accordance with the evidence set forth in Dr. Jordan's paper, than our accepted nomenclature, based as it was upon the conflicting testimony of Curier and Valenciennes, who embraced every thing known of the black bass, in their day, in their Grystes salmoides, except II uro nigricans, and had it not been for the gap in its dorsal fin. the inference is, they would have included that also. I do not make this statement unguardedly, or disrespectfully, for while I venerate the name of C'uvier, I am convinced that he failed to discriminate between the two species of black bass.

But let us begin at the beginning.

Now, if we discard both the description and figure of Cuvier and Talenciennes' Cirystes salmoides, we have left (ignoring for the time hoth Rafinesque and Le Sueur) only Lacépède's Labrus salmoides and Micropterus dolomieu. 
Let us take Lacépède's figure and description of Labrus salmoides, just as they are, on their own merits, without any reference to Cuvier's valuation of them; and to render the matter plain, I have reproduced, at the close of this chapter, fac-simile representations of Lacépède's plates of both Labrus salmoides and ILicropterus dolomieu, with his descriptions, from the original edition of his "Histoire Naturelle des Poissons."

In the first place, as Dr. Jordan truly says of the figure of Labrus salmoides: " if we must choose, the large-mouth is best represented." This is certainly correct, for no one could mistake this figure for a small-mouth black bass. Then, Lacépède's description says the opening of the mouth is very large ("l'ouverture de la bouche fort large"). The radial formula of the dorsal fin is given as nine spinous rays and thirteen soft rays ("neuf rayons aiguillonés et treize rayons articulés à la nageoire du dos"). This number of dorsal spines will hold good in seventy-five per cent. of cases, in the large-mouth bass of the south; sometimes there will be found but eight. The rest of the description will apply to either species. Then, again, Lacépède, on the authority of MI. Bose, says the species is very abundant in the rivers of Carolina, where they are called "trout" and are caught with the hook baited with a minnow ("On trouve un très-grande nombre d'indirdus de cette espèce dans toutes les rivières de la Caroline; on leur donne le nom de traut ou truite. On les prend à l'hameşon; on les attire par le moyen de morceaux de cyprin").

Now, if we had not been trying to reconcile Labrus salmoides with the small-mouth bass, contrary to the evidence of our own senses, so as to accord with Cuvier's creation of the complex Grystes salmoides - becoming blind to the points of difference and enlarging upon the 
vagueness and inaccuracy of the drawing and its description - we might have discovered that this figure had, as Lacépède says, a " very large mouth;" and that while the large-mouth black bass, or "trout" is "very abundant" in Carolina waters. the small-mouth black bass is apparently unknown, at least in the vicinity of Charleston, where Bosc collected.

As an angler, I have fished for the black bass in all the South Atlantic States, from Maryland to Florida; and while I have found the large-mouth bass "very abundant" in all parts of North Carolina, South Carolina, and Georgia. I never took a single small-mouth bass in either of these latter states within a hundred miles of the coast. I have taken it in the hill-country of each of these states, about the head-waters of the rivers flowing into the Atlantic, but I doubt very much if it is found anywhere in the lowland region of that section of country.

Dr. Edward D. Cope, who fished the streams of North Carolina, in the autumn of 1869 , from the Cumberland Mountains to the sea, found the large-mouth bass, "abundant in all the rivers of the state," but failed to find the small-mouth bass, except in the Alleghany region of the extreme western part of the state; and says that it is "aplarently not found east of the great water-shed."**

If the small-mouth black bass inhabits the Atlantic slopes of North Carolina, South Carolina, or Georgia. Dr. Holbrook would have known it; for there has been no ichthyologist. hefore or since his time, who understood the structure and habits of the "Carolina trout" so well. The best description, and the best figure of the large-mouth bass

* A Partial Srnopsis of the Fresh Water Fishes of North Carolina. By E. D. Cope, A.M. < Pro. Am. Phil. Soc., p. 450, 1870. 
("trout") ever published, until recent years, is found in his work, "Ichthyology of South Carolina."

In order to show that he clearly understood the relations of the black bass species, I will quote as follows:

"The trout has, however, its representatives both in the North and West, with which it is closely allied: as Grystes nigricans (Huro nigricuns) of Cuvier and Valenciennes, and Grystes fusciatus (Cychla fasciata) of Le Sueur, both of which have been referred by Agassiz to the genus Grystes." *

Dr. Holbrook knew that the southern trout (large-mouth black bass) was neither Huro nigricans (with its two distinct dorsal fins), nor Cichla fasciala (the small-mouth bass). He called the "trout" Grystes salmoides LacéPÈDE, (not G. salmoides Cur. \& Tal.), for he knew that Lacépède's Labrus sulmoides, or Bosc's Perca trutta could be nothing e else but the " Carolina trout" (large-mouth black bass) ; and, moreover, he distinctly repudiated Cuvier and Valenciennes' complex Grystes salmoides.

Professor Agassiz clearly recognized the complex character of Cuvier's Grystes salmoides, saying he "probably mistook slecimens of our Grystes fasciatus for the southern species." $\nmid$ Professor Agassiz regarded Grystes salmoides as the proper name for the southern large-mouth black bass (trout), and in comparing with it Grystes fasciatus, says:

"The mouth is less opened and the shorter labials do not reach a rertical line drawn across the hinder margin of the orbits, whilst they exceed such a line in G. salmoides." $\dagger$

* Ichthyyology of South Carolina. By John Edwards Holbrook, M.D. 25, 1855 .

†. Agassiz, Lake Superior, p. 295, 1850. 
And yet we deceived ourselves, with all this evidence staring us in the face, with the flimsy delusion that Bose's drawing of the "Carolina trout" was a small-mouth bass, simply because Cuvier pronounced it synonymous with Cichla variabilis Le Sueur and Micropterus dolomieu Lacépède.

Now, if we conclude from this that Labrus salmoides is the large-mouth black lass, then the small-mouth black bass claims its birthright of Micropterus dolomieu, which unquestionably belongs to it.

This, in slort, seemed to be the view of Dr. Vaillant, and it scemed to me to lie the correct one, though he took the figure of Grystes salmoides as additional evidence, the said figure being made from a large-mouth black bass, as is very evident from a glance at the reproduction of the original, which is given in this connection.

Boing thoroughly convinced that Labrus salmoides was a large-mouth black bass, from my own knowledge of the Carolina "trout," and from the views of Agassiz, Holbrook and Vaillant, I had fully determined to restore Lacépède's names, viz: Micropterus salmoides for the large-mouth bass and Mirropterus dolomieu for the small-mouth bass, in the first edition of this book.

There was but one contingency that could have proved the right of the small-mouth bass to the name Micropterus dolomieu in a stronger, or absolute manner, and it would be stronger, because incontrovertiible, namely: the priority of Inacéprede's rescription of Micropterus dolomicu to his description of Labrus salmoides, and it was my belief that such a contingeney really existed, for the following reasons:

In collating the bibliography of the black bass for the first edition of this book. I discovered an apparent diserepancy. which. if it really existed, had an important and 
significant bearing on the proper nomenclature of the species. I noticed that most American authors, in referring to Lacépède's description of Labrus salmoides, gave the reference as

"Lacépède, Hist. Nat. des Poiss. Vol. III, p. 716, 1800?", and that of Micropterus dolomieu as

"Lacépède, Hist. Nat. des Poiss. Vol. Iv, p. 325, 1800 ?"; thus, of course, giving the priority of description to Labru.s salmoides, as we then understood and accepted it.

On the other hand, I noticed that Cuvier and Talenciennes* gave the reference to Micropterus dolomieu in Lacépède's work as

"Vol. Iv, p. 325."

and that of Labrus salmoides in the same work, as

"Vol. Iv, pp. 716, 717 ."

I noticed further that all references to the figure of Lacépède's Micropterus dolomieu were given as

"Vol. 1v, pl. 3, fig. 3,"

and that of Labrus salmoides as

"Vol. Iv, pl. 5, fig. 2."

I was at once struck with this discrepaney, for if Cuvier and Valenciennes' reference of Labrus salmoides Lacépède (Vol. Ir, p. $716,71 \%$ ) was correct, it would give the priority of description to Micropterus dolomieu Lacépède (Tol. rv, p. 325). The numerical sequence of the plates also gave it priority.

While revising this chapter of the first edition of this book for the press, I learned from Dr. Jordan that he had just receired from France, a copy of Lacépède's original edition of his great work. I at once wrote to him to ascer-

${ }^{*}$ Cuv. \& Val. Hist. Nat. des Poiss. Vol. III, p. 55, 1829, ani Vol. v, p. v, 1830. 
tain which reference to Labrus sulmoides was the correct one. His characteristie reply was:

"In answering your questions I have struck a mare's nest; M. dolomicu, Vol. IV, 325, 1802; L. salmoides, Vol. Iv, 716, 1802; the latter being in a supplement, which, in some of the reprints, is restored to its proper place in the genus Labrus in Vol. III. From this you will see that dolomicu has priority over salmoides. I still believe that salmoides was intended for the large-mouth bass, but don't know that I can prove it."

Thus, after the lapse of four-fifths of a century, the small-mouth black bass recovered the name to which it was clearly entitled, Hicropterus dolomieu; truth and justice prevailed; Lacépède and his illustrious friend Dolomieu were vindicated.

American ichthyologists, it will be seen, had been misled by using a reprint, instead of the original edition, of Lacépède's work, which fact, together with an ill-placed faith in Cuvier, led to the confusion of the nomenclature of the black bass species as related in the preceding pages.

Perhaps it will now be well to refer to some objections beretofore raised to the generic title Micropterus, and the specific applellations sulmoides and dolomieu, on the score of irrelevaney. I might say, however, that priority, like charity, covers a multitade of sins.*

* To those anglers who are better posted in the technical terms of the great Ameriean "game" introduced to the nobility of England lyy General Schenck, than in the technical terms introduced here in reference to the nomenclature of the great American "game-fish," I need only say that Micropterus, and the specific names dolomieu and sammoides, "hold the age" over all other synonyms that have taken a hand, from time to time. in the "little game." This emparison may be more striking than analogieal, lut as .Tack Bunsby would say, its force "lies in the application of it." 
Micropterus (little-fin) is really less oljectional)le than any of the names proposed for the genus. for it has, comparatively: smaller fins than any of the related genera, though not in the sense intended by Lacépède.

Calliurus (beautiful tail) is not at all characteristic of the genus, though the young of the small-mouth species. in certain localities, has the tail marked as described by Rafinesque: "base yellow, middle blackish. tip white."

Grystes (growler) is certainly not applicalle in this sense. I never met an angler who had heard a black bass "growl," yet it was on the supposition that it did so, that Cuvier gare it this name. We had better stop here. for if we go farther we shall fare worse. We will now refer to the ohjectionable features of the specific names dolomieu and salmoides.

Salmoides (trout-like; literally, salmon-like). Lacépèrle conferred this name simply (and appropriately, so far as he was concerned) because the figure was sent to him as the "trout," or "trout-perch" of Carolina. If we take its game qualities into consideration, there is no fish that is so "salmon-like" as the black hass; none that exhilits so nearly the characteristic leap. the pluck. and the endurance of the "king of the waters." The name is, therefore, not altogether inappropriate.

Dolomicu being a French proper noun. without a Latin or genitive form, might be considered ohjectionable. Lacépède used the name, however. in this form. adrisedly; not through ignorance, nor by accident. but for the sake of euphony, and to perpetuate the name of his friend in its integrity. In order to recognize and respect Lacépède's motive, it is best to let the name stand just as he wrote it, dolomieu. As Dr. Vaillant adopts this form, and doubtless for the same reason, it is important for the sake of 
uniformity to allow it to stand. There is no lack of precedents for this form of specific title. I will merely mention as an example: Icterus baltimore - the former name of the Baltimore oriole. The title baltimore, as here used, is a proper noun, and was bestowed in honor of Lord Baltimore, whose livery was black and orange, the colors of the oriole or hanging-bird. Let the name of the small-mouth bass, then, stand as dolmieu - the name of a brave man for a brave fish.

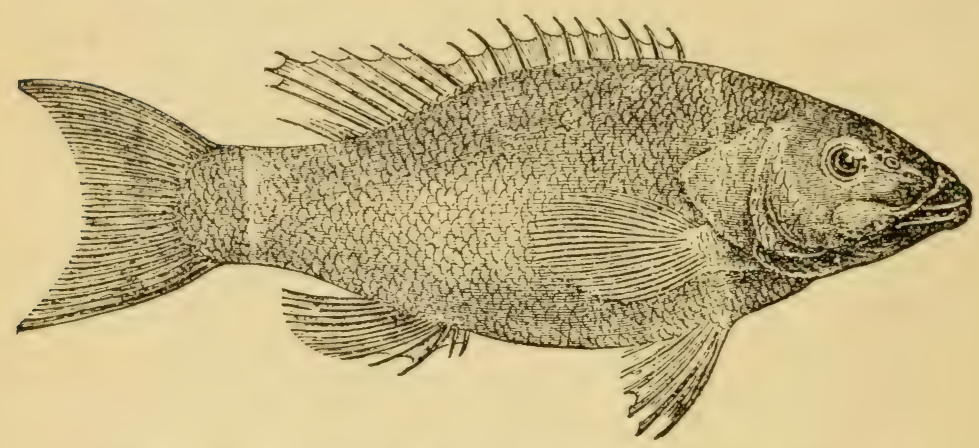

(This engraving is a fac-simile of that in Lacépède's Hist. Nat. des Poissons, Vol. IV, pl. 3, fig. 3.)

\section{Le Microptìre Dolomine.*}

Je desire que le nom de ce poisson, qu'aucun naturaliste n'a encore décrit, rappelle ma tendre amitié et ma profonde: estime pour lïillustre Dolomieu, dont la victoire vient de hriser les fers. En écrivant mon Discours sur la durée des espèces. j’ai exprimé la vive douleur que m’inspiroit son affremse captivité. et l'admiration pour sa constanee

\footnotetext{
* Micropterus dolomieu.
} 
hérö̈que, que l'Europe mêloit à ses væux pour lui. Qưiil m'est doux de ne pas terminer l'immense tableau que je tâche d'esquisser, sans aroir sente le bonheur de le serrer de nouveau dans mes bras!

Les microptères ressemblent beaucoup aux sciènes : mais la petitesse très-remarquable de leur seconde nageoire dorsale les en sépare; et c'est cette petitesse que désigne le nom générique que je leur ai donné.*

La collection du IIuséum national d'histoire naturelle renferme un bel individu de l'espèce que nous décrivons dans cette article. Cette espèce, qui est encore la seule inscrite dans le nouveau genre des microptères, que nons avons cru devoir établir, a les denx mâchoires, le palais et la langue, garnis d'un, très-grand nombre de rangées de dents petite, crochues et serrées; la langue est d'ailleurs très-libre dans ses mouvemens; et la mâchoire inférieure plus avancée que celle d'en-haut. La membrane hranchiale disparoit entièrement sous l'opercule, qui présente deux pièces, dont la première est arrondie dans son contour, et la seconde anguleuse. Cet opercule est courert de plusieurs écailles; celles de dos sont assez grandes et arrondies. La hauteur du corps proprement dit excède de beaucoup celle de l'origine de la queue. La ligne latérale se plie d'abord vers le bas, et se relève ensuite pour suivre la courlure du dos. Les nageoires pectorales et celle de l'anus sont trèsarrondies; la première du dos ne commence qu'à une assez. grande distance de la queue. Elle cesse d'être attachée au dos de l'animal, à l'endroit où elle parvient au-dessus de l'anale; mais elle ce prolonge en bande pointue et flottante jusqu'au-dessus de la seconde nageoire dorsale, qui est trèsbasse et très-petite, ainsi que nous renons dele dire, et que

- Míxoos, en grec, signifie petit. 
l'on croiroit au premier coup d'wil entierement adipeuse.* -(Lacreride. Il ist. Nal. des l'uiss. Vol. 1v, 325, 1802.)

\section{Le Labre salaioÏde. $\dagger$}

On devra au citnyen Bose la commossanese du labre salmoüde et du labre iris, yui tous les deux habitent dans les caux de la Caroline.

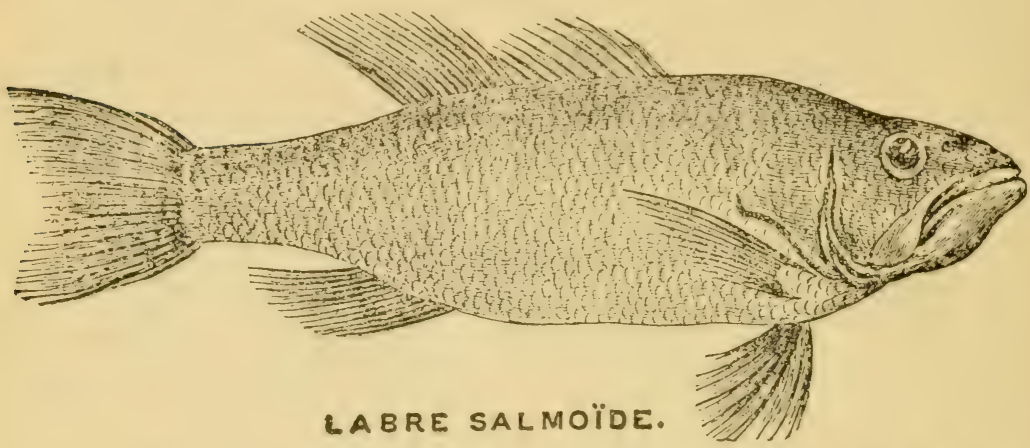

(This engraving is a fac-simile from Lacépède's Hist. Nat. des Poissons, Vol. Iv, pl. 5, fig. 2.)

Le salmö̈de a une petite élévation sur le nez; l'ouverture de la bouche fort large; la mâchoire inférieure un peu plus longue que la supérieure: l'une et l'autre garnies d’ume grande quantité de dents tris-menues; la langue charnue;

* 5 rayons à la membrane branchiale. 16 rayons à chaque pectorale.

1 rayon aiguillonné et 5 rayons articulés à chaque thoracine.

17 rayons it la nageoire de la queue.

- [D. X, 7-4; A. II, 11.]

† Labrus salmoïdes.

Perca trutta. Manuscrits communiqués par le citoyen Bosc. 
le palais hérissé de petites dents que l'on voit disposées sur deux rangées et sur une plaque triangulaire; le gosier situé au-dessus et au-dessous de deux autres plaque également hérissées; l'œil grand; les côtés de la tête, revêtus de petite écailles; la ligne latérale parallèle au dos; une fossette propre a recevoir la partie antérieure de la dorsale; les deux thoracines réunies par une membrane; l'iris jaune, et le ventre blanc.

On trouve un très-grand nombre d'individus de cette espèce dans toutes les rivières de la Caroline; on leur donne le nom de traut ou truite. On les presd à l'hameçon; on les attire par le moyen de morceaux de cyprin. Ils parviennent à la longueur de six ou sept décimètres; leur chair est ferme, et d'un goût très-agréable.- [Br. 6 ; D. IX, 13 ; A. 13 ; P. $13 ;$ V. 6 ; C. 18.] - (LACÉPÈDE, Hist. Nat. des Poiss. Vol. IV, 716, 1802.) 


\section{CHAPTER II.}

NOMENCLATURE AND MORPHOLOGY.

\section{Class PISCES. Subclass TELEOSTEI. \\ ORDER ACANTHOPTERI. \\ Suborder RHEGNOPTERI. \\ Family CENTRARCHIDA.}

SubfaMILY MICROPTERINA.

Genus Micropterus Lacépède.

SYNONYMY AND REFERENCES.

Microptems Lacépêde, Hist. Nat. des Poiss. IV, 325, 1802. (Type II. dolomieu Lac.)

Labrus species, LAcÉpède, Hist. Nat. des Poiss. Iv, 716, 1802. (L. salmoides Lac.) (Not of Linnæus, the type Labrus mixlus L. belonging to the family of Labrida, the common wrasse-fish of the coasts of Europe.)

Bodianus species, Rafinesque, Am. Mo. Mag. and Crit. Rev. II, 120, 1817. (B. achigan Raf.) (Not of Bloch, the type of Bodianus, being a marine fish of the family of Serranida.)

Calliurus Rafinesque, Jour. de Phys. v, 88, 420, June, 1819, and Ich. Ohi. 26, 1820. (Not of Agassiz, Girard, et al.) (Type C. punctulatus Raf.)

Lepom is RAFIEsqre, Ich. Ohi. 30, 1820. (Not Lepomis Raf. Jour. de Phys. II, 50, 1819, the original type Labrus auritus $\mathrm{L}$. being a fresh water sunfish.) 
Aplites Rafriesque, Ich. Ohi. 30, 1820. (As subgenus of Lepomis. Type $L$. pallidus Raf.)

Nemocampsis Rafixesque, Ich. Ohi. 31, 1820. (As subgenus of Lepomis. Type $L$. flexuolaris Raf.)

Dioplites Rafixesqce, Ich. Ohi. 32, 1820. (As subgenus of LCpomis. Type $L$. salmonea Raf.)

A plesion Rafinesqce, Ich. Ohi. 36, 1820. (As subgenus of Etheostoma. Type $E$. calliura Raf.)

Cichla species, Le Steur, Jour. Ac. Nat. Sci. Phil. Ir, 216, 1822. (C. fasciata Le S.) (Not of Cuvier, the type Cichla ocellaris Bloch, being a South American fresh water fish of the family of Cichlidw.)

Huro Cuvier \& Valexciexxes, Hist. Nat. des Poiss. II, 124, 1828.

(Type $H$. nigricans C. \& V.)

Grystes Cuvier \& Valenciexres, Hist. Nat. des Poiss. ilr, 54, 1829. (Type Labrus salmoides Lac.)

Huro Swansox, Nat. Hist. and Class. Fishes, ete., II, 200, 1839. Grystes Swanxsox, Nat. Hist. and Class. Fishes, ete., Ir, 202, 1839. Centrarchus species, Kintuaxd, Bost. Jour. Nat. Hist. r, 28, 1842. (C. fasciatus K.) (Not of Cuvier, the type Labrus ivideus Lac., being a fresh water sunfish.)

Centrarchus species, DeKAY, Fishes N. Y. 28, 1842. (C. fasciatus DeK.)

Grystes Agassiz, Am. Jour. Sei. and Arts. (2), xviI, 297, 1854. Dioplites Girard, U. S. Pac. R. R. Surv. x, Fishes, 4, 1858.

Grystes GüNTHER, Cat. Fishes Brit. Mus., I, 252, 1859.

Huro Günther, Cat. Fishes Brit. Mus., I, 255, 1859.

II icropterus Cope, Pro. Ac. Nat. Sci. Phil. 83, 1865. (Name only.)

Micropterus Gill, Ann. Rep. Dept. Agric. 407, 1866.

Micropterus Gill, Pro. Am. Asso. Adv. Sci. xxir, B. 55, 1873.

Dioplites Valllant \& Bococrt Miss. Sci. au Mexique, 1874.

Huro Bleeker, Syst. Perc. Revis. < Ext. des Arc. Neer. XI, 15, 1875.

Micropterus Blekrer, Syst. Perc. Revis. < Ext. des Are. Neer. $\mathrm{xI}, 15,1875$.

Micropterus Jondax, Man. Vert. E..U. S. 229, 1876.

Micropterus JoRdan, Am. N. Y. Lyc. Nat. Hist. XI, 313, 1877.

Micropterus Jordan, Pro. U. S. Nat. Mus. II, 218, 1880. 
Grystes GüNther, Intro. Study of Fishes, 392, 1880.

Huro Günther, Intro. Study of Fishes, 393, 1880.

Micropterus Cope, Bull. U. S. Nat. Mus., xvII, 32, 1880.

Micropterus Henshalt, Book of the Black Bass, 65, 1881.

II icropterus Cope, Rep. Pa. Fish Com., 130, 1881.

Mieropterus Jordax \& Gilbert, Syn. Fishes N. A., 484, 1882.

II icropterus Jordan, Geol. Surv. Ohio, iv, 942, 1882.

Mioropterus Vaillaxt \& Bocourt, Miss. Sei. au Mexique, 1883.

Micropterus GiLL, Standard Nat. Hist., III, 230, 1885.

IIicropterus JoRdAN, Manuel Vertebrates, 120, 1888.

Micropterus Jobdan \& Evermaxi, Fishes of N. A., 1010, 1896.

Micropterus Jordan \& Evermaxy, Amer. Food and Game Fishes, $355,1902$.

Micropterus Hexshald, Bass, Pike, Perch, and Others, 1, 1903.

ETYMology: Hexpós (miliros), small : arspór (pteron), fin TYPE: Hicropterus dolomieu Lacépède.

\section{GENERIC CHARACTERIZATIONS.}

Head well developed, its length varying from 3 to $3 \frac{1}{3}$ times in length of body; compressed; rather full between the eyes; snout rounded; profile straight; lower jaw prominent and projecting. Scales on cheek, operele, subopercle, and interoperele, but none, or few, on the preopercle. Ere moderately large. nearly median, but rather nearer the snout than the preoperele. Nostrils round and normal.

Mouth large, with the cleft oblique; the posterior extremity of the upper jaw extends nearly to, or beyond. the posterior border of the eye. Lips but slightly developed. Preopercle smooth and rounding at its angle. Opercle nearly triangular, emarginate behind, ending in two flat points. Subopercle extends beyond the opercle, ending in a membranous point. Interopercle rounded below. Gill openings large. Branchiostegals six on each side.

Both jaws are armed with villiform teeth, curving backward. Patches of villiform teeth on vomer, palatine and pharyngeal bones. Gill-rakers long and slender, and armed with teeth. 
Tongue moderate and free; thick behind, narrow in front; its surface usually smooth.

Body elongate, ovate-fusiform, somewhat compressed; deepest just behind the ventrals. Scales moderate; smaller on breast and nape. Lateral line following curve of the back.

Dorsal fin with nine or ten spines; a deep notch between the spinous and soft portions. Anal fin with three spines. Caudal fin emarginate.

Pyloric cœea fourteen or more. Air-bladder simple, slightly notehed behind.

\section{CONTRASTED DIFFERENTIAL CHARACTERISTICS.*}

Sirall-Mouth.

LARGE-MOUTH.

Scales of trunk

Small (e. g. lat. line, 72-75; Moderate (e. g. lat. line, 65between lateral line, and back, $\tau 0$; between lateral line and 11 rows). back, $71 / 2$ or 8 rows).

\section{Scales on nape and breast}

Much smaller than those of Searcely (on nape), or not sides. much (on breast) smaller than those of sides.

\section{Scales of cheeks}

Minute (e. g., between orbit Moderately small (e. g., beand preoperculum, about 17 tween orbit and preoperculum, rows in an oblique line and about 10 rows in an oblique line about 9 in a horizontal one). and about $5-6$ in a horizontal one).

\section{Scales of interoperculum uniserial}

Covering only about half the width of the bone.
Covering the entire width of the bone.

* On the species of the genus Micropterus (Lac.) or Grystes (Auct.). By Theodore Gill. Pro. Amer. Assn. Adv. Science; xxII, 1873. 
Small-Mouth.

LARGE-MOUTH.

Scales of preopercular limb

None.

Developed in an imperfect row (e. g., $3-\tilde{5}$ in number).

Scales on dorsal

Developed as a deep sheath Developed as a low (obsolete) (involving last spine) of small shallow sheath, and with series scales differentiated from those ascending comparatively little on the back, and with series ad- on membrane behind the rays vancing high up the membrane (none behind the last five or behind each ray (except last two six). or three).

\section{Scales on anal}

Ascending high behind each None (or very few). ray.

Mouth

Moderate.

Large.

\section{Supramaxillary}

Ending considerably in front Extending considerably beof hinder margin of orbit (about hind the posterior margin of under hinder border of pupil). orbit.

\section{Rays}

Dorsal articulated, 13.

Anal III, 10-11.

Pectoral, $1 \cdot 16-1 \cdot 17$.
Dorsal, articulated, 12 (I. 11).

Anal III, 10.

Pectoral, $1 \cdot 14 \cdot(1 \cdot 13)$.

\section{Dorsal fin in front of soft portion}

Little depressed, the ninth Much depressed, the ninth spine being only about a half spine being only about a fourth shorter than the longest $(3,4,5)$ as long as the longest and half and a fourth shorter than the as long as the tenth. tenth. 


\section{SYNOPSIS OF SPECIES OF MIICROPTERUS.}

Common characters.-Body elongated, orate-fusiform; slightly compressed; arched and thick along the back, thinner and straight along the belly; lower jaw longest; both jaws armed with broad bands of villiform teeth of uniform size; villiform teeth also on vomer, palatine and pharyngeal bones; teeth on gill-rakers; spinous and soft portions of dorsal fin partly divided by a notch; anal fin with three spines; caudal fin emarginate; opercule emarginate behind, ending in two flat points; supplemental maxillary bone well developed.

* Mouth large; angle of mouth anterior to the posterior border of the eye.

$\dagger$ Third dorsal spine only one-half higher than the first.

a. Notch between spinous and soft rays of dorsal comparatively shallow.

b. Scales small on body, much smaller on breast and hack of neck. and quite small on cheeks, in 17 rows; 11 rows of scales between lateral line and dorsal fin; 70 to 80 scales along the lateral line (exclusive of small pre-caudal scales).

c. No seales on preopercular limb.

d. Anal fin almost without scales. (?)

$e$. Head moderate in size; slightly convex between the orbits.

$f$. Color, slaty or dusky green on back and sides, shading to white on belly and lower jaw; young brighter green, and more or less spotted and marked with vertical bars; tail in young (in some localities), yellow at base, middle black, tip white; opercle with three oblique olivaceous streaks; D. X, 13 ; A. III, $11 \ldots \ldots \ldots \ldots \ldots \ldots$. DOLONIEU.

** Mouth very large; angle of mouth extends beyond the posterior border or the eye.

$\uparrow$ Third dorsal spine twice (at least) as high as the first.

aa. Dorsal notch deep, almost dividing the fin into two.

bb. Scales moderate; not much smaller on cheeks, nape or breast: scales on cheeks in 10 rows; 8 rows of scales between lateral line and dorsal fin; 65 to 70 scales along lateral line (exclusive of small pre-caudal scales).

cc. A single row of scales on preopercular limb,

dd. Anal fin somewhat scaly.

$e e$. Head large; flat between the orbits. 
ff. Color, olive green, darker on back and shading to white on belly and under side of lower jaw; more or less spotted when young; not barred, though usually an irregular dark lateral band; three oblique streaks on cheeks; these markings grow obscure with age; D. X, 12; A. III,

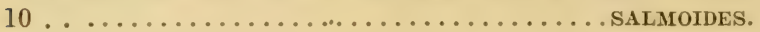

\section{CHRONOLOGICAL CATALOGUE}

\section{of the Tominal Species of Micropterus as noticed by various Authors, with Identifications.}

\begin{tabular}{|c|c|c|}
\hline NOMINAL SPECIES. & Date. & Identifications. \\
\hline opterus & 1802 & Micropterus dolomieu. \\
\hline Labrus salmoides Lacépède & 1802 & Micropterus salmoides. \\
\hline Bodianus achigan Rafinesque & 1817 & Micropterus dolomieu. \\
\hline Calliurus punctulatus Rafines & 1819 & Micropterus dolomieu. \\
\hline Lepomis pallida Rafinesque & & Micropterus salmoides. \\
\hline Lepomis trifasciata Rafines & 1820 & Micropterus dolomieu. \\
\hline Lepomis flexuolaris Rafinesque & 1820 & Mieropterus dolomieu. \\
\hline Lepomis salmonea Rafinesque. & 1820 & Micropterus dolomieu. \\
\hline Lepomis notata Rafinesque & 1820 & Micropterus dolomieu. \\
\hline Etheostoma calliura Rafinesque. & 1820 & Micropterus dolomieu. \\
\hline Cichla variabilis Le Sueur, MSS. . & 1822 & Micropterus dolomieu. \\
\hline Cichla fasciata Le Sueur .. & 1822 & Micropterus dolomieu. \\
\hline Cichla ohiensis Le Sue & 1822 & Micropterus dolomieu. \\
\hline Cichla minima Le Sueur & 1822 & Micropterus dolomieu. \\
\hline Cichla floridana Le St & 1822 & Micropterus salmoides. \\
\hline Huro nigricans Cuvier \& Valen & $18: 28$ & Micropterus salmoides. \\
\hline Grystes salmoides Curier \& Val & $18: 29$ & Micropterus dolomieu? \\
\hline Centrarchus obseu & 1842 & Micropterus dolomieu. \\
\hline Centrarehus fasciatus Kirtland & 1842 & Micropterus dolomieu. \\
\hline Grystes nigricans Aga & 1850 & Micropterus salmoides. \\
\hline Grystes fasciatus Ag & 1850 & Micropterus dolomieu. \\
\hline Grystes nobilis Agassiz & 1854 & Micropterus salmoides. \\
\hline Grystes nuecensis Bair & 1854 & Micropterus salmoides. \\
\hline Grystes salmoides Holbrook & 1855 & Micropterus salmoides. \\
\hline Grystes megastoma Gs & 1857 & Micropterus salmoides. \\
\hline Grystes nigi & 1857 & Mieropterus dolomieu. \\
\hline Dioplites nuecen & 1858 & Micropterus salmoides. \\
\hline Grystes salmonc & 1859 & Micropterus dolomieu. \\
\hline Grystes nigriea & 1859 & Micropterus salmoides. \\
\hline Lepomis achig & 1800 & Micropterus dolomieu. \\
\hline Mieropterus nigricans $\mathrm{Co}$ & 1865 & Micropterus salmoides. \\
\hline Micropterus fasciatus Cope & 1865 & Micropterus dolomieu. \\
\hline Micropterus ac & 1866 & Micropterus dolomieu. \\
\hline Micropterus sa & $18 \pi 3$ & Micropterus dolomieu. \\
\hline Dioplites treculii Vaillant \& Boc & 1874 & Micropterus salmọides. \\
\hline Dioplites nuecensis Vaillant \& B & 1874 & Micropterus salmoides. \\
\hline Dioplites variabilis Vaillan & 1874 & M. dolo var achigan. \\
\hline Dioplites salmoides Vaillant \& Bo & $18 \pi 4$ & Micropterus salmoides. \\
\hline Mieropterus floridanus Goode & $18 \pi 6$ & Micropterus salmoide \\
\hline Micropterus pallidu & 1877 & Micropterus salmoides. \\
\hline Micropterus salmoides $v a r$. salm & 1878 & MI. dolomieu var. dolo. \\
\hline icropterus salmoides var. achig & 1878 & II. dolo. var. achigan. \\
\hline Micropterus salmoides Vaillant \& & $\begin{array}{l}1883 \\
1840\end{array}$ & Micropterus salmoides. \\
\hline Micropterus nuecensis Vaillant \& & 1843 & Micropterus salmoide \\
\hline Micropterus variabilis Vaillant & 1883 & M. dolo. var, achigan \\
\hline Micropterus dolomieu Vaillant \& Bocourt & 1883 & M. dolomieu var. dolo. \\
\hline
\end{tabular}




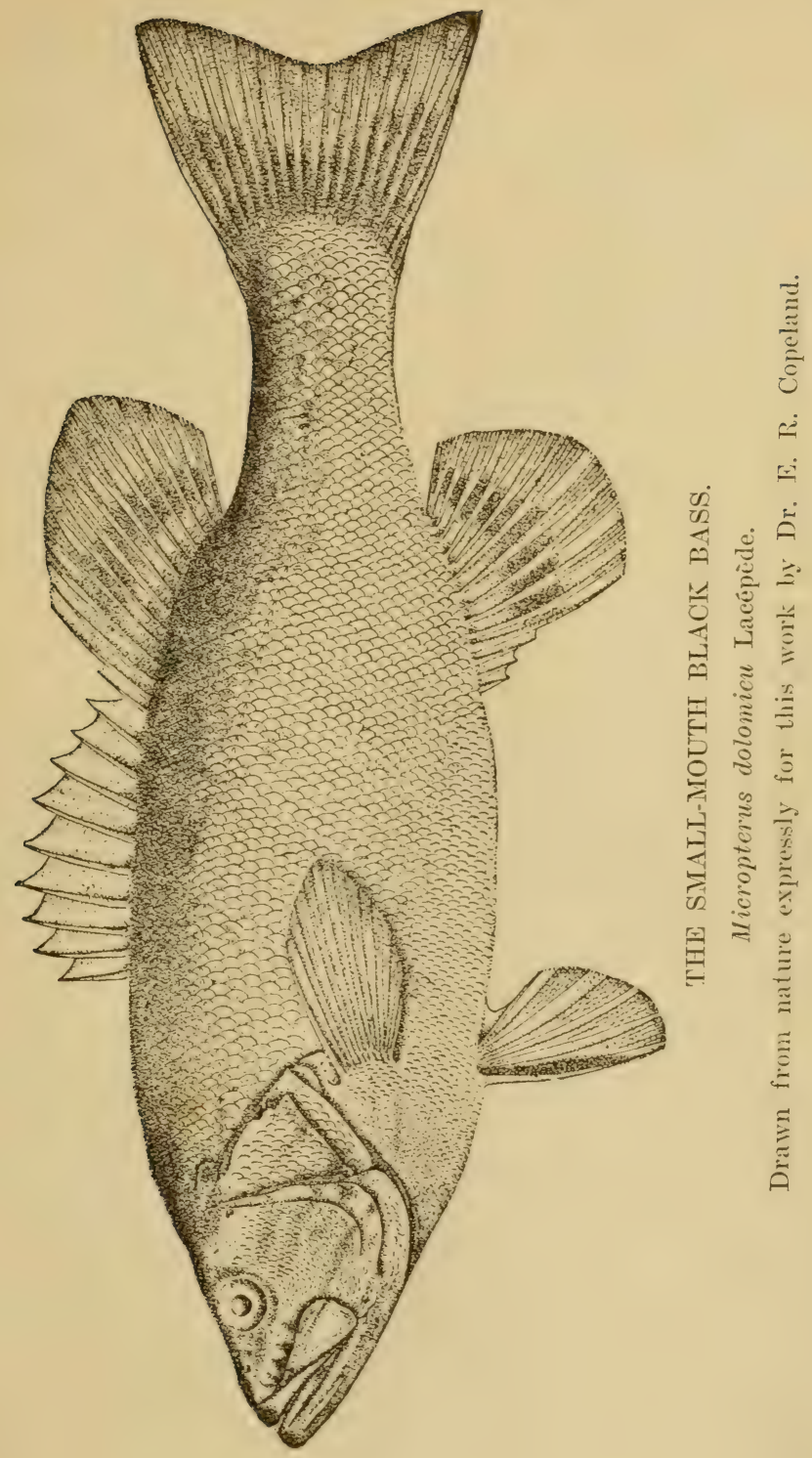





\section{MICROPTERUS DOLOMIEU LACÉPÈDE.}

\section{THE SMALL-MOUTH BLACK BASS.}

SYNONYMY AND REFERENCES.

1802.

IIicropterus dolomicu LACÉPÈde, Hist. Nat. des Poiss., iv, 325, 1802.

Jicropterus dolomieu Hexshald, Book of the Black Bass, 84, 1881. Micropterus dolomieu MICKaY, Pro. U. S. Nat. MLus., w, 93, 1881. .Micropterus dolomieu Jordan \& Gilbert, Syn. Fishes N. A., $485,1882$.

.Micropterus dolomieu Jordax, Geol. Surv. Ohio, iv, 948, 188?.

.Micropterus dolomieu Vaillayt \& Bocotrt, Miss. Sci. au Mex., Zool., 1883.

.I icropterus dolomiei Beax, Bull. U. S. Nat. MIus., Xxrir, 464, $502,1883$.

Miciopterus dolomiei Jordax \& Swarx, Pro. L. S. Nat. Mus., VI, 249, 1883.

Micropterus dolomiei Beax, Pro. U. S. Nat. Mus., vi, 365, 1883. IV icropterus dolomiei Goode, Fish. Industries L. S., sec. I, 401, 1884.

Micropterus dolomiei Forbes, Rept. Ills. Fish Com., 6ī, 1884. Micropterus dolomieu GiLl, Standard Nat. Hist., III, 231, 1885. Micropterus dolomiei Jordan, Cat. Fishes N. A., 17, 1885.

II icropterus dolomiei Yox DEM Bonxe, Die Fischzucht, 148, 185.5. Micropterus dolomiei Jorday \& Meer, Pro. U. S. Nat. Mus., vIII, 7, 1885.

Micropterus dolomiei Eigexmaxy \& Fordice, Pro. Ac. Nat. Sci. Phil., 411, 1885.

Micropterus dolomiei Jordan \& Gilbert, Pro. U. S. Nat. Mus., $\mathrm{Ix}, 5,12,1886$.

Micropterus dolomieu MAther, Colvin Adirond. Surv., Fishes, 5, 1886.

Micropterus dolomiei Evermaxx, Bull. Brook. Soc. Nat. Hist. II, $7,1886$.

Micropterus dolomici Erermaxy \& Bollmax, Ann. N. Y. Lye. Nat. Hist., 339, 1886.

Micropterus dolomieu Jordan \& Evermaxx, Ind. Agric. Rept., $13,1886$. 
Micropterus dolomieu ToN DEM Borxe, Schwarzbarsch, ete., :3, 1886.

Micropterus dolomiei Goode, American Fishes, 54, 1888.

Micropterus dolomieu JoRDAx, Manual Vertebrates, 120, $18 s 8$.

II icropterus dolomieu JoRDAN \& Evermanx, Fishes of N. A., $1011,1896$.

Hicropterus dolomieu Jordax \& Evermaxx, Am. Food and Game Fishes, 355, 1902.

Micropterus dolomicu Hexsmald, Bass, Pike, Perch and Others, 3, 1903.

\section{7.}

Bodiamus achigan RAfixesqte, Am. Mo. Mag. and Crit. Rer. II, $120,1817$.

Lepomis achigan GILL, Pro. Ac. Nat. Sci. Phil. 20, 1860.

Micropterus achigan GILL, Rept. Com. Agri. 407, 1866.

Micropterus achigan Goode \& BEAx, Bull. Essex Inst. xi, 19, $1879 .^{*}$

1820.

calliums punctulatus Rafixesqre, Ich. Ohiensis, 26, 1820.

Lepomis trifasciata Rafinesque, Ich. Ohiensis, 31, 1820.

Lepomis flexuolaris Rafrnesque, Ich. Ohiensis, 31, 1820.

Lepomis salmonea RAfrnesque, Ich. Ohiensis, 32, 1820.

Lepomis notata Rafinesque, Ich. Ohiensis, 32, 1820.

Etheostoma calliura Rafinesque, Ich. Ohiensis, 36, 1820.

1822.

Cichla variabilis Le SEetr, MSS., in Musemm d'Ilist. Nat. Paris, 1822.

Dioplites variabilis VanLlant \& Bocourt, MSS. Miss. Sci. au Mexique, 1874.

Micropterus raviabilis Vanllaxt \& Bocourt, Miss. Sci. au Mexique: ined.

* Used on the wrong supposition that the name "Labre salmoüle" as used by Lacépède was vernacular (French), unaccompanied by a classical form, and therefore not available. 
1822.

Cichla fasciata Le Sueur, Jour. Ac. Nat. Sci. Phil. II, 216, 1822. Cichla fasciala Kintland, Zoology Ohio (2d An. Rep. Geol. Surv. Ohio), 191, 1838.

Centrarchus fasciatus Kirtlayd, Bost. Jour. Nat. Hist. v, 28, 1842. Centrarchus fasciatus DeKaY, Fishes N. Y. 28, 1842.

Centrarchus fasciatus Storer, Syn. Fishes N. A. 38, 1846.

Grystes fasciatus AgAssiz, Lake Superior, 295, 1850.

Centrarchus fasciatus Thompson, Hist. Vt. 131, 1853.

Grystes fasciatus EoFf, Smithsonian Report, 289, 1854.

Grystes fasciatus GiLl, Smithsonian Report, 257, 1856.

Centrarchus fasciatus GüNther, Cat. Fishes Brit. Mus. I, 258, 1859.

Grystes fasciatus Güxthen, Cat. Fishes Brit. Mus. I, 252, 1859.

(Name only.)

Centrarchus fasciatus Roosevelt, Game Fish of North, 217, 1862. Micropterus fasciatus Cope, Pro. Ac. Nat. Sci. Phil. 83, 1865. (Name only.)

Grystes fasciatus PutraM, Storer's Fish Mass. 278, 1867.

Micropterus fasciatus Cope, Jour. Ac. Nat. Sci. Phil. vi. 216, 1868. Micropterus fasciatus Cope, Pro. Am. Phil. Soc. 450, 1870.

\section{2.}

Cichla ohiensis Le Sueur, Jour. Ac. Nat. Sei. Phil. II, 218, 1822. Cichla ohiensis Kirtland, Rept. Zool. Ohio: 2d Geol. Rept. Ohio, $191,1838$.

1822.

Cichla minima Le Sueur, Jour. Ac. Nat. Sci. Phil. II, 220, 1822. Cichla minima Kirtland, Rept. Zool. Ohio: 2d Geol. Rept. Ohio, $191,1838$.

1829.

? Grystes salmoides Cevier \& Valenciennes, Hist. Nat. des Poiss. III, 54, 1829.

Grystes salmoides Jardive, Nat. Lib. I, Perches, 158, 1835.

Grystes salmoides DEKAY, Fishes N. Y. 26, 1842.

Grystes salmoides Storer, Synopsis Fishes N. A. 36, 1846.

Gristes salmoeides Herbert, Fish and Fishing, 197, 1859.

Grystes salmonoides Güntrier, Cat. Fishes Brit. Mus. I, 252, 1859.

Micropterus salmoides Gill, Pro. Am. Asso. Adv. Sci. B 55, 1873. 
Micropterus salmoides Jordan, Ind. Geol. Surv. 214, 1874. Micropterus salmoides Jondan, Man. Vert. E. U. S. 230, 1876.

Hicropterus salmoides UHLer \& LugGer, Fishes of Md. III, 1876. Jicropterus salmoides NeLsox, Bull. Ills. State Lab. Hist., I, 37, 1876.

MI icropterus salmoides Jordan, Ann. N. Y. Lye. Nat. Hist. XI, $314,1877$.

Micropterus salmoides Jordax, Bull. U. S. Nat. Mus. Ix, and $\mathbf{x}$, 1877.

Micropterus salmoides HaLlock, Sportsman's Gazetteer, 373, 1877. (In part.)

Micropterus salmoides Jordai, Man. Vert. E. U. S. $2 d$ ed., 236, 1878.

Micropterus salmoides Jondan, Bull. U. S. Nat. Mus. xir, 30, 1878.

Micropterus salmoides Hexsmald, Rept. Ohio Fish Com. 31, 1879. Micropterus salmoides Goode, Bull. U. S. Nat. Mus., 49, 1879.

Micropterus salmoides Jordax, Pro. U. S. Nat. Mus. II, 218, 1880. Micropterus salmoides Goone, Bull. U. S. Nat. Mus., X, 28, 1880. Micropterus salmoides BeAN, Pro. U. S. Nat. Mus., III, 1880. Micropterus salmoides Cope, Rept. Pa. Fish Com., 1881.

1842.

Cicntrarchus obscurus DeKay, Fishes New York, 30, 1842. Centrarchus obscurus Storer, Syn. Fishes N. A. 40, 1846. Contrarchus obscurus Güxtmer, Cat. Fishes Brit. Mus. I, 258, 1859.

\section{7.}

Grystes nigricans Ganlick, Treat. Art. Prop. Fish, 105, 1857.

Grystes nigricans Norris, Am. Anglers' Book, 103, 1864.

Etrmology: Dolomicu, proper name (in honor of M. Dolomieu). Habitat: Canada to Alabama; along the Appalachian Chain and westward; introduced eastward. 


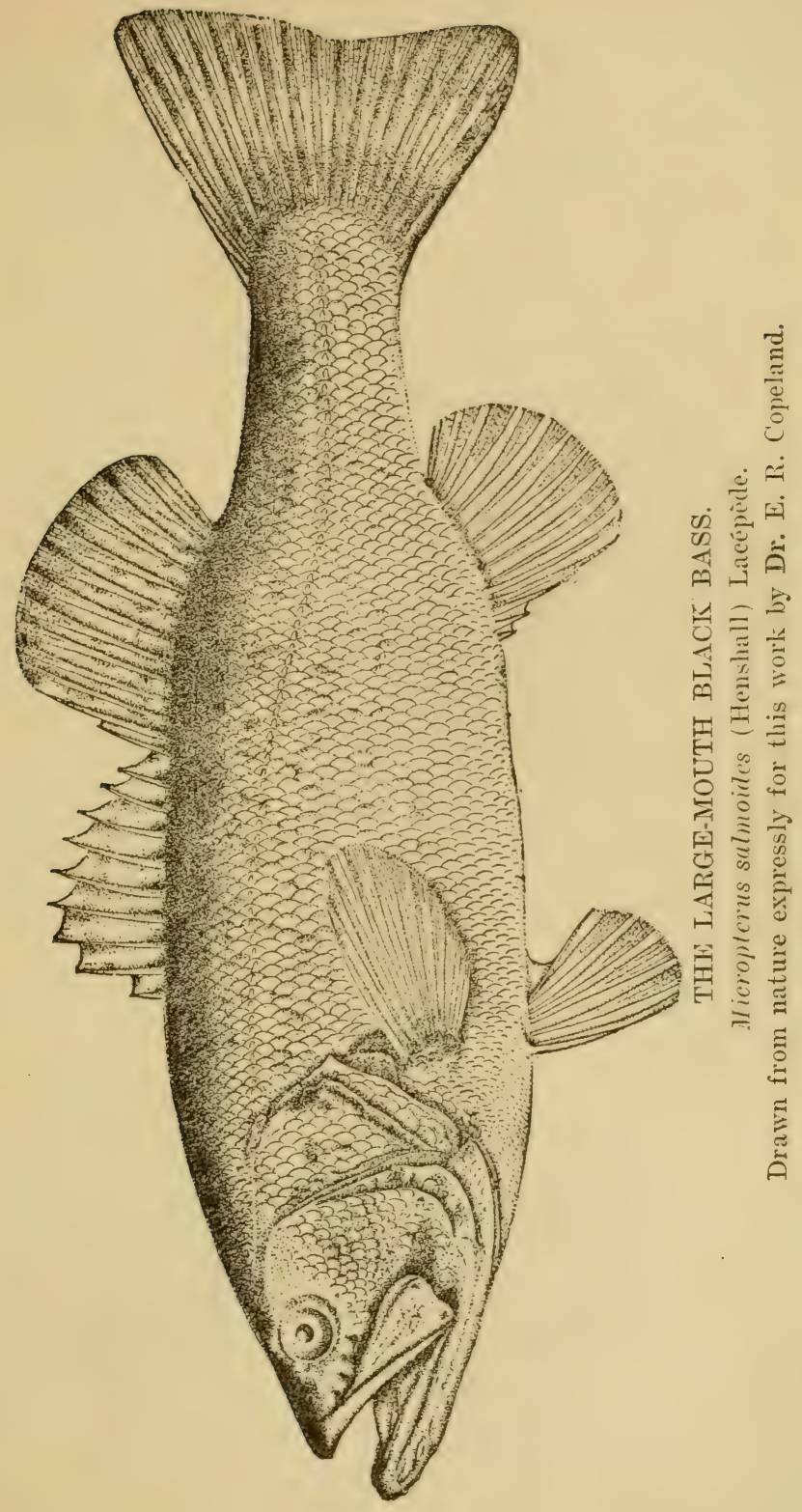





\title{
MICROPTERUS SALMIOIDES (Lic.) Hexshall.
}

\section{THE LARGE-MIOUTH BLACK BASS.}

\author{
SYNONYMY AND REEERENCES.
}

1802.

Labrus salmoides LAcépède, Hist. Nat. des Poiss. IV, T16, 1802.

Grystes salmoides Holbrook, Cat. Fauna and Flora. Statisties of Ga., 16, 1849.

Grystes salmoides AGAssiz, Lake Superior, 295, 1850.

Girysies salmoides Holbrook, Ich. So. Car. 25. 1855, and $2 \mathrm{~d}$ ed. 2S, 1860.

Grystes salmoirles Norris, Am. Anglers' Book, 99, 1864. II part.)

lioplites salmoides V'Alllaxt \& Bocourt, Miss. Sici. au Mexique, 1874.

Microplerus salmoides Hensiall, Book of the Black Bass, 110 , 1881.

Mieropterus salmoides, McKay, Pro. U. S. Nat. Mus., Ir, 93, 1881.

Micropterus salmoides Goode \& Bear, Pro. U. S. Nat. Mus., v, 238, 1882.

Micropterus salmoides Jordax \& GILbert, Syn. Fishes N. A., 484, 1882.

Micropterus sa!moides Jordan, Geol. Surv. Ohio, Ir, 952, 1882.

Micropterus sulmoides Hay, Bull. U. S. Fish Com., II, 64, 1882. Micropterus salmoides BeAN, Bull. U. S. Nat. Mus., Xxvir, 446 , $502,1883$.

Micropterus salmoides VAILlant \& Bocourt, Miss. Sci. au Mexique, 1883.

Micropterus sulmoirles Goode, Fish. Industries U. S. sec. I, 401, 1884.

Micropterus salmoides Gilbert, Pro. U. S. Nat. Mus. vir, 204, $209,1884$.

Micropterus salmoides Jordax, Pro. L. S. Nat. Mus., rir, 320, 1884. II icropterus salmoides Fonbes, Rept. Ills. Fish Com., 67, 1884.

Micropterus salmoides Gill, Standard Nat. Hist.. I1I, 231, 1855. Micropterus salmoides Jondan, Cat. Fishes N. A., 17, 1885.

Micropterus salmoides Jordax \& MeEK, Pro. U. S. Nat. Mus., VIII, 14, 16, 17, 1885.

Jicroptcrus salmoides Goode \& BEAN, Pro. U. S. Nat. Mus., VIII, 208, 1885. 
Micropterus sulmonoides Vox DEM BonxE, Fischzucht, 14S, 1885. Micropterus salmoides Jordan \& Gilbert, Pro. C. S. Nat. Mus., $\mathrm{Ix}, 21,1886$.

Micropterus salmoides Bollmax, Pro. U. S. Nat. Mus., Ix, 464, 1886.

Micropterus salmoidcs Evermaxx, Bull. Brook. Soc. Nat. Hist., II, 7, 1886.

Micropterus salmoides Jondax \& Evenmaxx, Ind. Agric. Rept., $13,1886$.

Micropterus salmoides Jexiscs, Hoosier Naturalist, 95, 1886.

Microptcrus sulmoides Vox DEM Borive, Schwarzbarsch, etc., 3, 1886.

Micropterus salmoides Goode, American Fishes, 54, 1888.

Micropterus sulmoides Jondax, Manual Vertebrates, 120, 1888.

Micropterus sulmoides Jordan \& Evermanx, Fishes of N. A., $1012,1896$.

Micropterus salmoides Jordax \& Evermaxy, Am. Food and Game Fishes, 357, 1902.

II icropterus satmoides HexsindL, Bass, Pike, Perch and Others, $30,1903$.

\section{0.}

Liepomis pallida Rafinesque, Ich. Ohiensis, 30, 1820.

I ieropterus pullidus Jordax, Ann. N. Y. Lyc. Nat. Hist. XI, 314, 1877.

Micropterus pallidus Jordax, Bull L. S. Nat. Mus. Ix, 21, and $\mathrm{x}, 43,1877$.

Micropteris pallidus Jondax, Bull. L. S. Nat. Mus. Xir, 15, 1878. Micropterus pallidus Jondax, Hayd. Geol. Surv. Ter. Bull. Iv, No. 2, 435, 1878.

Micropterus pallidus Jordax, Man. Vert. E. U. S. 2d ed., 236, 1878.

Micropterus pallidus Goone, Pro. C. S. Nat. Mus. II, 115, 1879.

Micropterus pallidus Goode \& BeAx, Bull. Essex. Inst. XI, 19, 1879.

Micropterus pallidus Goode \& BeAx, Pro. U. S. Nat. Mus. II, 138, 1879.

Mficropterus pallidus Hensmall, Rept. Fish Com. Ohio, 31, 1879. Micropterus pallidus Goode, Bull. U. S. Nat. Mus., xıv, 49, 1879. 
.Micropterus pallidus Jordax, Pro. U. S. Nat. Mus. III, 19, 1880. Microptcrus pallidus Goode, Bull. U. S. Nat. Mfus., XrmI, 28, 1880. Micropterus pallidus BEAx, Pro. U. S. Nat. Mus., III, 96, 1880. Micropterus pallidus Hay, Pro. U. S. Nat. MIus. III, 497, 1880. Micropterus pallidus Cope, Rept. Pa. Fish Com., 131, 1881.

\section{2.}

Cichla floridana Le Suevr, Jour. Act. Nat. Sci. Phil. II, 219, 1822. Micropterus floridanus Goode, Bull. U. S. Nat. Mus.s. VI, 63, 1876. (Name only.)

Micropterus floridanus CopE, Bull. U. S. Nat. MIus., xvir, 31, 1880.

1828.

Huro nigricans Cevier \& Valexciexdes, Hist. Nat. des Poiss. II, $124,1828$.

Huro nigricans Jardine, Nat. Lib. I, Perches, 108, 1835.

Huro nigricans RICHaRdson, Fau. Bor. Am. III, 4, 1836.

Huro nigricans DeKaY, Fishes N. Y. 15, 1842.

Huro nigricans Storer, Syn. Fishes N. A. 25, 1846.

Grystes nigricans AGassiz, Lake Superior, 297, 1850.

Grystes nigricans Hereert, Fish and Fishing, 195, 1859.

Huro nigricans GüxtheR, Cat. Fishes Brit. MLus. I, 255 , 1859.

Huro nigricans Rooserelt, Game Fish of the North, 219, 1862.

Mficropterus nigricans Cope, Pro. Ac. Nat. Sci. Phil. 83, 1865.

(Name only.)

Micropterus nigricans Gill, Rept. Com. Agric. 407, 1866.

Micropterus nigricans Cope, Pro. Am. Phil. Soc. 451, 1870.

Micropterus nigricans Gill, Pro. Am. Asso. Adv. Sci. B. 70, 1873.

Micropterus nigricans JoRdax, Ind. Geol. Surv. 214, 1874.

Micropterus nigricans JoRdax, Man. Vert. E. U. S. 229, 1876.

Micropterus nigricans NeLsox, Bull. Ills. State Lab. Nat. Hist., I, $36,1876$.

Micropterus nigricans HALLock, Sportsman's Gazetteer, 273, 1877. (In part.)

1854.

Grystes nobilis Agassiz, Am. Jour. Sci. Art, xrir, 298, 1854. Grystes nobilis Putxas, Bull. Mus. Comp. Zool. I, 6, 1863. (Name only.) 
1854.

Grystes muccensis BaIro \& Girard, Pro. Ac. Nat. Sci. Phil. vir, $25,1854$.

Dioplites nuccensis Girard, C. S. Pac. R. R. Surv. x, Fishes, 4, 1858.

Grystes nuccensis Gïxtren, Cat. Fishes Brit. Mus. I, 252, 1859. (Name only.)

Dioplites muecensis Girard, U. S. Mex. Bound. Surv. ir, 3, 1859. Dioplites mecensis VaIllaxt \& Bocourt, Miss. Sci. au Mexique, 1874.

Micropterus mecensis Valllaxt \& Bocolnt, Miss. Sci. au Mexique, 1883.

1857.

Grystes megastoma Gindick, Treat. Art. Prop. Fish, 108, 1857.

1874.

Dioplites treculii VaIllant \& Bocourt, Miss. Sci. au Mexique, 1874. (Zoölogie, pt. IV, plate IV, f. 2. No description; the species since identified by its authors with 1I. nuecensis.)

Eтrmologr: Salmoides, trout-like; salmon-like.

Habitat: Red River of the North to Florida: Virginia to Mexico: introduced eastward. 


\section{CHAPTER III.}

GENERAL AND SPECIFIC FEATURES.

"Like - but oh! how different!"- WordsworTH.

As has been shown in the preceding chapter, the genus Micropterus includes but two species, viz: Micropterus dolomieu Lacépède, the small-mouth black bass, and Micropterus salmoides (Lacépède) Henshall, the large-mouth black bass, or, as it is sometimes erroneously called, the Oswego bass. The small-mouth bass exhibits some minor points of difference between its northern and southern forms, which, however, are not of much moment, as they shade into each other, and are to be regarded as merely geographical variations.

Dr. Edward D. Cope took several large-mouth bass, in T'exas,* which, while agreeing in all other features with the same species of the northern states and of Florida, differed somewhat in the smaller size of the scales of the cheeks, and in the scaling of the gill-covers. They also differed slightly in coloration and markings by showing several dusky, longitudinal streaks, especially noticeable below the lateral line. I observed these several variations, though not quite so pronounced, in several large-mouth bass taken in the St. Francis River, Arkansas, in the autumn of 1885.

Possibly no genus of fishes has been the occasion of so much confusion, scientifically and popularly, as the black

* On the Zoological Position of Texas. By E. D. Cope. > Bull. U. S. Nat. Mus., xvir, 1880, 31. 
bass. This is owing, no doubt, to its extensive habitat and wide-spread distribution, the original habitat of one or other of the species being the great basin of the St. Lawrence, the whole Mississippi Talley - or nearly the entire range of country lying between the Appalachian Chain and the Rocky Mountains - and the South Atlantic States from Tirginia to Florida, including also the widely-separated sections of the Red River of the North and East Mexico.

It would naturally be expected, in view of this extraordinary and expansive habitat, to find differences in color, halits and conformation; indeed, it is surprising that the variations are not more marked, and the number of species, consequently, greater, when one considers the great natural differences and conditions of the numerous waters, and the varieties of climate to which this genus is native. To the careless observer, however, there is but little to determine the differences between the two species of black bass. I have lnown anglers who never suspected that there was any difference except in color, until I pointed out to them the specific characteristics. Even those of more attentive observation, but who have never seen the two species together, find it difficult to readily comprehend the difference. To the trained observer, howerer, it is an easy task to distinguish the rariations; and when specimens of equal weight, of both species, are placed side by side, the difference is at once apparent.

As widely distributed as the black bass is, we find that the most striking variation, in either species, is in color, which will run from almost black through all the shades of slate, green, bronze, olive and yellow to almost white; and indeed these variations in color can be found in almost any one state. and to a great extent in any one stream, or 
lake, at different seasons of the year. In most sections of the country the small-mouth species is more or less spotted or barred, while the other species may exhibit well-defined lateral bands of dark spots, though these peculiarities are more pronounced in young or adolescent specimens.

The fins will also be found to vary somewhat in coloring, while the scales and fin-rays may differ slightly in number, as a rariation of one-sixth, more or less, from established formulas is not unusual. Slight dissimilarities of contour, and some diversities of habits, also, exist. But all of these differences obtain, not only with regard to the black bass, but to most other species of fresh-water fishes, and depend on well-known natural causes.

I resided for ten years in Wisconsin, where there were twenty lakes, abounding in black bass, within a radius of eight miles of my residence; and from close and constant olservation of the characteristics of the bass inhabiting them, I could almost invariably tell, upon being shown a string of black bass, in what particular lake they had been caught.

Where both species co-exist in the same waters, the smallmouth bass is generally of a darker or more somber huc than the large-mouth bass, whose color is more inclined to shades of green. The coloration of the small-mouth bass, howerer, in some localities, approaches shades of olive or yellow, and there will often be more or less red in the iris of the eye, in some instances shading down to orange or yellow; this latter distinction, though, like the double curve at the base of the caudal fin, and the more forked tail which have been regarded by some anglers as distinguishing characteristics of this species - can not be depended on, as one or all of these distinctions may be lacking.

The most distinctive feature, as between the two species, 
is the gape of the mouth, which in the large-mouth bass seems simply enormous to those who have previously seen but the small-mouth species. The contrast in build, and external conformation, of the two species, is at once striking and characteristic. The large-mouth bass is thicker, especially through the shoulders, deeper in the body, and seems a heavier fish for its length than the other species, conveying the impression that it is the stronger and more powerful fish, as, indeed, it is; while the small-mouth bass, owing to its trim, slender and more graceful shape, truly convinces one that it is the more active and agile.

The relative size of the scales is all important in the differentiation of the two species. In the large-mouth bass these are much larger, there being but from sixty-five to seventy scales along the lateral line, running from the heat to the tail; while in the small-mouth species there are from seventy to eighty. Between the lateral line and the base of the dorsal fin there are but eight horizontal rows of scales in the large-mouth bass. while there are eleven similar rows in the small-mouth bass. The scales on the nape and breast in the large-mouth species are not much smaller than those of the sides; but in the other species they are much smaller; and while the scales on the cheeks and gill-covers of the large-mouth bass are small, those of corresponding situations in the small-mouth bass are quite minute, with a small portion of the gill-covers (preopercular limb) entirely bare.

The size and shape of the fins also differ somewhat, especially the dorsal, which in the small-mouth bass has the rays of the spinous portion higher and more uniform in size, rendering this fin higher, not so arching, and with a shallower notch than in the large-mouth form.

The differences, then, in the form, gape of mouth, and 
size of scales and fins of the two species of black bass, without reference to color, are sufficiently pronounced to enable the angler to readily distinguish, by comparison, the smallmouth from the large-mouth; for these differences are constant wherever the black bass exists, from Maine to Mexico, or from Canada to Florida. To the specialist there are other points of differentiation as detailed in the preceding chapter.

The late Fred Mather has humorously expressed these differences in the following characteristic lines:

"The little-mouth has little scales, There's red in his handsome eye; The scales extend on his vertical fins, And his forehead is round and high.

His forehead is full and high, my boys,

And he sleeps the winter through;

He likes the rocks in summer time,

Micropterus dolomieu.

The big-mouth has the biggest scales,

And a pit scooped in his head;

His mouth is cut beyond his eye,

In which is nary a red.

In his eye is nary a red, my boys,

But keen and well he sees;

He has a dark stripe on his side,

Micropterus salmoides."

Both species are remarkably actire, muscular and roracious, with large, hard and tough mouths; are very bold in biting, and when hooked exhibit gameness and endurance second to no other fish. Both species give off the characteristic musky odor when caught. 
Both species often inhabit the same waters in the northern states, and there is some diversity in their habits where they exist together. Naturally, the small-mouth bass prefers rocky streams or the gravelly shoals and bottom springs of lakes and ponds. while its large-mouth congener lurks about the submerged roots of trees or sunken logs in rivers, and delights in the beds of rushes and aquatic plants of lacustrine waters; but they readily adapt themselves to waters of various conditions, when transplanted, easily accommodating themselves to their surroundings, and have a happy faculty of making themselves at home wherever placed, so that in some localities their habits are as anomalous as their colors.

There is a prevalent notion that the small-mouth bass is the "game" species par excellence. In common with most anglers I at one time shared this belief, but from a long series of ohservations I am of the opinion that the large-mouth bass, all things being equal, displays as much pluck, and exhibits as untiring fighting qualities as its small-mouth cousin.

Ichthyologists have at various times given to the genus Micropterus numerous appellatives, and to the species more than fifty specific names, while laymen in different sections of the country have contributed their quota of vernacular names, among which may he mentioned: bass, black bass, green hass. yellow hass, river hass, bayou bass, slough bass, lake bass, moss bass, grass bass, marsh bass. Oswego bass, swago bass, perch, hlack perch, yellow perch, trout perch, jumping perch, Welshman. salmon, trout, black trout, white trout, chub, southern (huh, Roanoke chub, achigan, etc.

In addition to this formidable and perplexing array of names, there are other erils which add rery much to the confusion attending the nomenclature of the black bass. 
Among them is the careless habit of many correspondents of our sportsmen's journals, who write of bass, bass tackle, bass fishing, etc., meaning black bass in each instance, but leave it to the imagination of the readers of those journals as to what particular kind of "bass" is meant.

Now this is all wrong, and is owing to carelessness, or perhaps in some instances to a want of proper information, and is a habit that ought to be reformed. We should learn to call things by their right names. A rose by any other name may smell as sweet, but as there are many varieties of roses they must be distinguished by correct and specific names, and not by their odors. It is just as easy to write the distinctive name "black bass" as the general name "bass."

Bass is a very vague term at best, meaning one thing in one part of the country, and a totally different thing in another. Along the eastern coast it means a striped bass (Roccus lineatus), or a sea bass (Centropristes striatus); in Florida it means a channel bass (Scianops ocellatus); in the west it may be either a black bass (Micropterus), a rock bass (Ambloplites rupestris), a white bass (Roccus chrysops), or a calico bass (Pomoxys sparoides); while in Otsego County, New York, it means an Otsego bass (Coregonus clupeiformis var. otsego), which is not a bass at all but a whitefish.

Then, again, some of these correspondents write of the real black bass, meaning usually the small-mouth species, seeming to imply that the other species is not real, or at least is not the black bass, but something else - a kind of pseudo variety. Others in writing of the large-mouth species, owing to its former name, M. nigricans, have called it the real black bass, under the impression that as it was named nigricans - i. e., black - the other species must be 
some other color, and could not be the simon-pure article. Now, one species is not more real than the other; the smallmouth bass is regarded as the type species because it was the first to be described by a naturalist, and given a specific and generic name.

The term "black bass," then, is distinctive, and should always be used when alluding to the genus generally. The different species should be mentioned as the small-mouth black bass or the large-mouth black bass, as the case may be, no matter whether the color be black, green or yellow. One will then know exactly what is meant, and the confusion and uncertaintv alluded to will be cleared away:

"Not chaos-like, together crush'd and bruis'd, But, as the world, harmoniously confus'd, Where order in variety we see, And where, though all things differ, all agree."- Pope. 


\section{CHAPTER IV.}

\section{COLORATION OF THE BLACK BASS.}

"And it is so with many kinds of fish, and of trouts especially; which differ in their bigness and shape, and spots and color."IZAAK WALTON.

TIIE external appearance of the black bass, as exhibited in the colors and markings, differs so greatly and constantly in different sections of our country, that it would be useless to describe them minutely in a specimen from any given locality; for as the vernacular names of fishes are usually bestowed with reference to the outward peculiarities of coloring, this has already given rise to much confusion in naming the species. Thus they are called black, green, or yellow bass, respectively, in different sections of the United States, and not without reason, for black, green or yellow are the predominating colors of the two species, though these colors are always toned down to intermediate shades, with plumbeous, olivaceous or ochreous tints.

The color, however, is always darkest on the back, with a gradual shading or paling toward the belly or abdomen, which is always white or whitish. Where the two species of black bass are common to the same stream or lake, the small-mouth bass is generally the darkest in color, though this is by no means an invariable rule; for in other waters the small-mouth bass may be of a lighter or paler hue than the other species - usually yellowish-olive or tawny-gray, but often pale green - while the large-mouth bass will be of a dark green or bronze green coloration, and sometimes quite dusky. 
Then, again, in some waters, no distinct coloring is apparent, the fish presenting merely a pale or faded appearance; especially is this likely to be the case in large streams much subject to overflow, and whose waters are often muddy or discolored. Hence, as may be surmised, color is not an important factor in the differentiation of the black bass species.

While some have no distinct markings, others are marked by dark, maculated, transverse or vertical bars ; some, again, by longitudinal or lateral bands; and still others by mottled lines, dusky sjots, or finger marks. Usually, when bass are so marked, the mottled bands run lengthwise in the large-mouth species, while the small-mouth bass is marked by transverse bars or finger marks; but these distinctions are not infallible. The small-mouth hass of the extreme southwest exhibits, sometimes, several mottled lines running lengthwise along the series of scales.

After being taken out of the water, the colors and markings of the fish change materially; usually, the brighter colors fade rapidly, while the dusky spots, bars, or bands become more distinct; this change of color is more frequently olserved in the small-mouth species. Sometimes, however, the markings will disappear, and the sides of the fish will assume a uniform coloration.

Then, again, the colors of the black bass frequently change with each season of the year; and there is, moreover, always a marked difference in the colors and markings of the fish at different stages of its growth. In the young, the colors are brighter and the markings more distinct than in the adult fish, for it is not unusual for the latter to become almost obsolete with age.

The fins are likewise subject to variation in coloring and markings; they may be either dusky or greenish, reddish 
or yellowish, and are, usually, nore or less punctulated or spotted. The tail is often lighter in color at the base and outer edge, and dark or dusky between; thus one of the names proposed by Rafinesque for the small-mouth species - C'ulliurus punclulatus, i. e., "dotted painted-tail" was founded upon the peculiar coloration of the tail of a young bass, his description of the caudal fin being: "base yellow, middle blackish, tip white." Sometimes, however, especially in mature specimens, the tail has a dark border, - while the middle is of a lighter tinge; and often the entire caudal fin will have a uniform coloration.

There are, commonly, several - usually three - dusky or olivacenus streaks along the cheek and gill-covers.

Inconstancy of coloration is not exceptional with the black lass, for all other genera of fresh water and anadromous fishes exhibit this peculiarity in a greater or less degree. Among the causes assigned for the changes in coloration, and which have been either proven true or made tenable by actual experiment and careful observation, are: (1) character of food; (2) condition, depth and temperature of water; (3) color and character of beds of streams. lakes or ponds; ( 4 ) atmospheric conditions; (5) age; (6) season of the year; and ( 7 ) the changes incident to the breeding season; while some assume that (8) the power of changing color is voluntary with some, if not all, fishes.

Richard Owen, in "Anatomy of the Vertebrates," says:

"The varied, and often brilliant colors of fishes, are due to pigment cells at different depths of the skin, but chiefly in the active or differentiating area. Those of silvery or golden luster are mostly on the surface of the scales. The silvery pigment called 'argentine' is an article of commerce used for the coloring of fictitious pearls, and offers a crystalline character under 
the microscope. The blue, red, green, or other bright-colored pigment is usually associated with fine oil, and occupies areolæ favoring accumulation at, or retreat from, the superficies, and thus effecting changes in the color of the fish, harmonizing their exterior with the hue of the bottom of their haunts."

From the nature of the pigment cells, as portrayed in this description, it is easy to imagine how susceptible they are to the influences of such causes as those above enumerated.

The Salmonida have been more studied, perhaps, than any other family of fishes, and yet in none has there been more confusion in classification, owing in a great measure to the differences of external appearance, as caused by these various influences.

The German naturalist, Scibold, says: "In none of our native [German] fish is there such variety of color, according to the different influences of food, water, light and temperature, as in the toothed salmons."

Another German scientist, Carl Peyrer, says of the common brook trout of (iermany (Trutta fario): "The color, and partly also the size which it reaches, vary according to its location, the influences of light, the season, water, and food, and therefore several varieties are distinguished, such as the forest or stone trout, the alpine or mountain trout, the gold or pond trout, the lake trout, and, according to the lighter or darker coloring, the white trout, the black trout, ete." Truly almost as polyonomous as our black bass.

That difference in food produces difference in coloration is pretty generally admitted. Those of the salmon family which feed upon crustacea and larvæ exhibit the most brilliant colors, while those which live upon insects, minnows, worms, etc., are much duller in hue. 
Sir Humphrey Dary, in his familiar work, "Salmonia," says :

"I think it possible when trout feed much on hard substances, such as larvæ and their cases, and the ova of other fish, they have more red spots and redder fins. This is the case with the gillaroo and the char, who feed on analogous substances; and the trout that have similar habits might be expected to resemble them. When trout feed on small fish, as minnows, and on flies, they have more tendency to become spotted with small black spots, and are generally more silvery."

Charles Lanman, an angling artist and author, says :

"Various causes have been assigned for the great variety in the color of the brook trout. One great cause is the difference of food; such as live upon fresh-water shrimps and other crustacea, are the brightest; those which feed upon May-flies and other aquatic insects are the next; and those which feed upon worms are the dullest and darkest of all."

Dr. A. T. Thompson, the author of "Treasury of Natural History," observes:

"That each species of trout has its peculiarities of color, but the common trout is the most beautiful of its class; the variations of its tints and spots, from golden-yellow to crimson and greenishblack, are almost infinite, and depend in a great measure on the nature of its food, for the colors are always the most brilliant in those fish that feed on the water shrimp."

Near Waterville, Waukesha County, Wisconsin, thirty years ago, was an extensive trout hatching establishment, where a number of fine springs formed a considerable stream after leaving the ponds and flumes, and into which a number of brook trout had escaped at various times, so that finally it became well stocked with trout, which propa- 
gated naturally in the stream. The trout which were reared artificially were kept in covered plank flumes, and in open ponds, and were fed principally on chopped liver; those in the ponds got some addition to this fare, however, in aquatic flies, insects, etc. The stream contained a great many crawfish, which did much damage to the dams and ditches of adjacent cranherry marshes. Frequently visiting this establishment, I was struck with the remarkable difference in the colors of the trout in the flumes, in the ponds, and in the stream. Those in the flumes were quite dull in appearance; those in the ponds were brighter; while those in the stream were very highly colored, caused, perhaps, by their feeding upon the crawfish with which the stream abounded. The dull color of the trout in the flumes was partly owing to their shaded condition.

Not only does the character of the food seem to influence the extermal coloring of the salmon family, but the tint of the flesh, if I may so call it, may also be affecterl by the same cause; thus, Louis Agassiz states that the most heautiful salmon-trout are found in waters which abound in crustacea, direct experiments having shown to his satisfaction that the intensity of the red color of their flesh depends upon the quantity of Gammarida (shrimp) which they have devoured.

The red-throat trout (Salmo clarkii lewisi) of Henrys Iake, at the head of Snake River, in Idaho, and likewise those of Soda Butte Lake in the Yellowstone National Park, are noted for the deep red tint of their flesh - as red as that of the Chinook salmon - and on this account are erroneously called "salmon-trout." The probable cause of their red flesh may be found in the extraordinary abundance of fresh-water shrimp that inhabit both lakes, which are of similar character, being shallow, with muddy 
bottom and a luxurious growth of water weeds, conditions exceedingly favorable for the growth and increase of the shrimp.

A striking instance of the difference in coloring of the flesh from the influence of age or scason, is related by the European ichthyologist, Dr. Fric, in regard to the salmon of Bohemia. He says that there are three different ascents of the salmon during the year: The first ascent begins in February or March under the ice, and lasts till May. These salmon weigh from twenty-five to fifty pounds, and aro famous under the name of "violet-salmon." The second ascent begins in June and lasts till August. These fish have a reddish flesh, and weigh from twelve to twenty-two pounds, and are known as "rose-salmon." The third ascent is from September until December. These fish are mostly weak, weighing from three to fifteen pounds. Their flesh is pale, and they are usually called "silversalmon."

The trout of the mountain lakes of the Alps, according to the season and the nature of the water they inhabit, have their flesh whitish or reddish.

The color and condition of the water has likewise a very marked effect upon the external appearance of the Salmonidc. Agassiz found that the color of book trout of neighboring streams was influenced by the color and quantity of the water, and that eren trout of the same stream differed in color as they frequented the shady or sunny side. He also found that fish in clear, sunny waters, with gravelly bottoms, were highly and brightly colored; while those in shady streams, or where the bottom was dark or muddy, and the water not so clear, were correspondingly dusky in hue; and that bright fish taken from waters of the former character and placed in those of the latter, 
would begin to fade in a few hours, and in a few days or weeks would become entirely changed in hue.

The great lake trout (Cristivomer namaycush) exists in three different states of color, according to situations in which it is found, and were thought by the French habitans of the great lakes to be three distinct fishes, known as truite de gréce, or trout of the muddy bottom; truite des battures, or trout of the rocky shores; and truite du large, or trout of the deep, open waters; the first being inll-colored, the second bright and handsomely mottled, and the last bluish and silvery.

Charles Lamman truly observes, that the fish of streams rushing rapidly over pebbly beds, are superior both in appearance and quality to those of ponds or semi-stagnant hrooks. But this may arise. not so much from any particular components of the waters themselves, as from the fact that rapidly running and falling water is more highly aerated, the atmosphere being more freely intermingled with it, and therefore more conducive to the health and condition of all that inhabit it.

The influence of light in producing color in fishes is very evident when we reflect that fishes are always colored upon the back, which is exposed to the direct rays of light, and pale underneath, usually being quite white on the abdomen. This fact is especially pronounced in the flat fishes, which swim upon the side; thus the flounder, the sole, the turbot, the halibut, etc., are dark and variously colored upon the side presented to the light, while they are quite pale or white on the under side. Fishes which inhabit dark caves, owing to the absence of light, are entirely colorless.

That the age of fish has much to do with their color is well known; a familiar example being the common gold- 
fish, which in early youth is black or dark colored, and only assumes its beautiful golden hue at maturity.

During the breeding seasoin of fishes their colors become much heightened, but they lose their brightness and brilliancy in many cases when the season is over. A salmon fresh-run from the sea is justly considered the most beautiful of fishes, but after the spawning season there is none more sorry and ill-looking. Darwin mentions some very interesting particulars, among which, that the pike, especially the male, during the breeding season, exhibits colors exceedingly intense, brilliant and iridescent.

Another striking instance out of many is afforded by the male stickleback, which is described by Mr. Warrington (England) as being then beautiful beyond description:

"The back and eyes of the female, on the other hand, are the most splended green, having a metallic luster like the green feather of humming-birds. The throat and belly are of a bright crimson, the back of an ashy green, and the whole fish appears as thcugh it was somewhat translucent, and glowed with an internal incandescence. After the breeding season, these colors all change; the throat and belly become of a paler red, the back more green, and the glowing tints subside."

The well-known and beautiful spring, or breeding dresses, of many of our darters and minnows, are common illustrations of the influence of the breeding season upon the change of color in fishes.

The coloration of the young of the small-mouth bass is light green, with golden reflections, and with numerous small dots or punctulations, which aggregate in small clusters, approaching somewhat the appearance of vertical hars. The iris is golden. The base of the caudal fin is yellowish, the tip whitish, and dark olivaceous or blackish in the middle. 
In the young of the large-mouth bass the color is also greenish but darker, with a blackish band along the lateral line, and clusters of dark spots above and below. The iris is golden. The base and tip of the caudal fin is somewhat paler than in the middle.

Those who keep their fish alive in fish-cars or live-boxes, or by the more reprehensible practice of stringing the fish, will olserve that however different in coloration fishes of the same species may appear when first caught, that after being subjected to the same conditions for a few hours they will all exhibit the same coloration.

A familiar instance of the change of coloration due to environment, or change in the condition, character, depth or temperature of the water, or in the food, is seen in the Canadian sea-trout. This is merely the brook-trout that has become anadromous and runs to the sea. When it returns, in the spring or early summer, to the mouths of the streams, it is, like most marine fishes, of a bright, silvery appearance; but after being in fresh water a short time it again takes on the characteristic colors and spots of the brook-trout. I have taken them in both their salt-water and fresh-water colors, and in a transition stage, in the Restigouche River, between Matapedia and Campbellton, New Brunswick.

The external coloration of fishes depends on the presence of variously-colored pigment-cells in one or both layers of the skin. These pigment-cells are said to be under the influence or control of the nerrous system, and are thus able to cause changes of color which may be rapid or temporary, or more or less permanent.

In some fishes, as the black bass, the change in coloration is involuntary, and is, without much doubt, occasioned by an increase or decrease in the number of the different 
pigment-cells, owing to the influences of light, depth of water, temperature, surroundings, etc.

In some other fishes the change of coloration is much more rapid, and seems to depend on a contraction or expansion of the pigment-cells already developed, and which are rery sensitive to surrounding conditions, especially to light. Owing to this rapid change in the colors of certain fishes, when exposed to the light, they are thought by some to be endowed with the power of changing their colors at will, or voluntarily. This, however, is not very likely. 


\section{CHAPTER V.}

\section{GEOGRAPHICAL DISTRIBUTION.}

"You may remember that I told you, Gesner says there are no pikes in Spain; and doubtless, there was a time, about a hundred or a few more years ago. when there were no carps in England." IZAAK WALTON.

THE black bass is wholly unknown in the Old World, except where recently introduced, and exists, naturally, only in North America. The original habitat of the genus is remarkable for its extent, for, with the exception of the New England states and the Atlantic seaboard of the middle states, it comprised the whole of the United States east of the Rocky Mountains, Ontario (C'anada), and East Mexico.

Of late years the range of the black bass has been extended through the efforts of public-spirited individuals, and by the Fish Commissioners of various states, so that at the present time this noble fish may be said to have a "local habitation and a name" in every state of the Union. It has also been successfully introduced into England, Scotland and the Continent of Europe.

Of the two species, the large-mouth bass had the widest distribution, occurring all through the vast scope of territory as mentioned. The small-mouth bass had a somewhat limited range in comparison, not extending east or soutl beyond the Alleghany mountains, though occurring nearly everywhere else, except in the Gulf states, with the largemouth species.

The fact that the original habitat of the black bass did not embrace New England and the Pacific slope is not re- 
markable, for the characteristically American forms of fishes are, generally speaking, rare or absent in the waters of those sections. This fact was noticed by Louis Agassiz, who called New England "a zoological island," on account of its faunal peculiarities as compared with the rest of the United States. Thus, of more than a hundred genera of fresh-water fishes now known to occur in the waters east of the Mississippi River, only about one-fourth oceur in New England, and of these, all except a half-dozen genera are represented by but a single species each; and not more than thirty-five genera occur in the waters of the Pacific slope. Almost any stream of any extent of the Ohio or Mississippi basins will furnish double the number of genera and species as the entire waters of either of the abovenamed sections. Thus, as Dr. Jordan states, "In the little White River, at Indianapolis, seventy species, representing forty-eight genera, are known to occur - twice as many as inhabit all the rivers of New England."

The distribution of the black bass does not seem to be much affected by geological formations, climatic influences, or the character of waters; for although one or both species may have been absent originally in certain localities, they readily adapt themselves to the waters of these sections when transplanted, and rapidly increase.

Originally, both species were at home among the primordial rocks of the eozoic period of Lake Champlain, northcrn Wisconsin, and along the Appalachian chain in the Carolinas and northern Georgia. They flourished amid the paleozoic rocks of the Great Lake region and the Mississippi Talley, and in the coal measures of the Ohio, Illinois, and Missouri River basins; while in the marine tertiary formations of the cenozoic period, along the At- 
lantic and Gulf slopes of the southern states, the largemouth bass alone occurs. Thus, while the small-mouth bass seems to be restricted naturally to the older formations. the large-mouth bass roams at his own sweet will through the regions of metamorphic and stratified rocks and glacial drift, down to the recently formed coral rocks of the peninsula of Florida.

Climatic influences do not seem to affect the distribution of the large-mouth hass in any degree, in the United States, and of the small-mouth bass only to a small extent. The original halistat of the species extended through twenty-five degrees of latitude and thirty degrees of longitude, the small-mouth bass alone not occurring in the extreme ten degrees of southern latitude, and the ten degrees of extreme western longitude of this range. Thus. while the small-mouth hass is naturally restricted to cold and temperate waters, the large-mouth hase bids defiance alike to the ice-bound streams of Camada. the tropical lagoons of east Mexien, and the sumny streams of southern Florida. He flashes his bright armor unter the firs and birches of the St. Lawrener hasin. and rerets his spiny crest in the grateful shade of the pralns and live oalis of the southern peinsula. To him it is given

"To bathe in fiery floods, or to reside

In thrilling regions of thick-ribbed ice."

The character of waters has but little influence upon the distribution of the species. less upon the large-mouth bass than upon his small-mouth congener. If the water is reasonably pure. both species will thrive in it; but, as has just been intimated, the small-month bass naturally seeks cooler and clearer waters. Thus. while he is found in the headwaters of certain rivers flowing into the Atlantic (notably 
those of the Alleghany region of the Carolinas, Georgia, and Alabama), the large-mouth bass only occurs in the lower portions of the streams. There are several rivers in Hernando County, on the Gulf coast of Florida, that burst out from the base of a sandy ridge running parallel with the coast, and some twelve miles from it, whose sources are large springs. fifty or sixty feet deep, and of half an acre in extent. Their waters are remarkably clear and cool, with a strong current until tide-water is reached; and I have no doubt but the small-mouth bass would thrive wonderfully well in the upper portions of the streams if introduced into them, as the conditions all seem favorable, and the large-mouth bass is abundant in them.

As we approach tide-water, the small-mouth bass disappears. The large-mouth bass, however, true to his cosmopolitan nature, descends the streams to their mouths, where he seems to be as much at home in the brackish waters of the estuaries as in the pure and crystal rapids of the highlands.

The black bass being in a manner omnivorous, is probably not restricted in its range to any great extent by the supply of any one article of his food, though it would be affected, of course, by an abundance or scarcity of its food, as a whole. Crawfish and minnows are the principal food of adult black bass, and these are more or less plentiful throughout the waters of the United States. In addition to these, they feed upon insects, larvæ, frogs, etc. The greater prevalence of crawfish in clear, rocky streams, may throw some light upon the preference of small-mouth bass for such waters.

The following account, by the late James IT. Milner, of the U. S. Fish Commission, of the introduction of the black bass into new waters, will be found very interesting 
and instructive, and is taken from the Report of the U. S. Fish Commissioner for the years 1872-73:

"Among numerous records of their introduction, in very few instances discriminating properly between the two species, we give the following: In 1850, twenty-seven live bass were brought by Mr. Samuel Tisdale, of East Wareham, Mass., from Saratoga Lake and put into Flax Lake, near his home. In the years 1851 and 1852, others were brought to the number of two hundred and reared in ponds in the vicinity. The matter was kept quiet and fishing discouraged for five years, when the fish were found to have increased very rapidly. Some twenty-five ponds were stocked in the same county after Mr. Tisdale had initiated the experiment. Afterward, black bass from Mr. Tisdale's ponds were supplied to a lake in New Hampshire in 1867, and to waters in Commecticut. and Massachusetts. In 18 (ifi the Cuttyhunk Club, of Massachusetts, introduced black bass into a pond in their grounds. In the year 1869 the Commissioners of the State, together with private parties, stocked several ponds and the Concord liver with black bass, and in the following year other waters were stocked.

"In Connecticut, in the winter of 1852-53. the black bass was introduced into Waramang Lake, in Litchfield county. They were brought from a small lake in Dutchess County, New York. A few years later they were said to have increased greatly. Another lake in the same county was stocked not long afterward.

"Salstonstall Lake, near New Haven; East Hampton Pond, in Chatham; Winsted Pond, in Winchester, and many ponds and lakes of the state, particularly in the northwest portion, were stocked with the black bass previous to the year 1867 .

"In the years 1869, 1870, 1871, and 1872, thirty-seven lakes and ponds in different parts of the state were supplied with black bass.

"As early as 1864 or 1865 black bass had been put into Rust's Pond, near Wolfborough. New IIampshire; in 1868 a few were brought to Charlestown and Lakes Massabesic. Sunapee, Pemacook, and Echo, and Enfield, Wilson's and Cocheco Ponds were well stocked; in 1870 and 1871 the New Hampshire Commissioners introduced the black bass from Lake Champlain into the waters of the state at Meredith, Canaan, Webster, Canterbury, 
Harrisville, Munsonville, Hillsborough, Warner, Sutton, New London, Andover, Loudon, Concord, and in Croydon. In Massabesic and Sunapee Lakes, where they had been introduced, in 1868 and 1869, they were found to have increased, and, on the authority of Dr. W. W. Fletcher, they have become exceedingly numerous in Sunapee Lake.

"The Commissioners of the state of Rhode Island, since 1870 , have stocked thirty ponds or small lakes in different parts of the state with the black bass.

"In Maine, in the fall of 1869, the State Commissioners and the Oquossoc Angling Association introduced from Newburgh, New York, a quantity of black bass. The waters of Duck Pond, at Falmouth; Fitz Pond, in Dedham; Newport and Philips Ponds, Cochnewagan Pond, in Monmouth; Cobbosseecontee Lake, in Winthrop and adjoining towns, were stocked, and a few years afterward were reported to have increased largely in numbers.

"Since the year 1871, black bass [small-mouth] and Oswego bass [large-mouth] have been put into seventy lakes, ponds, or streams of the state of New York by the Commissioners. They had made their way of their own accord through the canals connecting Lake Erie with the Hudson, into that stream.

"Private citizens of Pennsylvania introduced the black bass [small-mouth] into the Susquehanna about 1869, at Harrisburg. In 1873 the tributaries of the Susquehanna, the Potomac, and Delaware Rivers were supplied with black bass by the Commissioners at thirty-five different points.

"In the year 1854, Mrr. William Shriver, of Wheeling, Virginia, planted in the canal basin at Cumberland, Maryland, his former home, a number of the black bass [small-mouth]; from the basin they escaped into the Potomac River, where they have increased immensely at the present day. They were moved from the waters of the Ohio River to their new locality in the tank of a locomotive. Numerous eases have also occurred of transfer from one locality in the southern states to another.

"There have been very many transfers of these valuable species that have not been recorded, as they are easily kept alive while being moved from one place to another, and propagate surely and rapidly in ponds, lakes, and rivers.

"These details are given because they show the facility with 
which comparatively barren waters may be stocked to a considerable extent with good food-fishes, and they exhibit the general interest and attention that have been given to this mode of propagation."

In the account above given, reference is made to the stocking of the Potomac River with black bass by Gen(ral $\mathrm{W}$. W. Shriver, of Wheeling, West Virginia. As this matter is often alluded to on account of the marvelous increase of the fish from so small a beginning - less than thirty bass having been originally transplanted - and as other parties have been accredited with the praiseworthy act who had nothing whatever to do with it, and whom I will not even mention here, it may not scem out of place to give the subject a little more space in this connection.

The earliest referenee to the matter, of which I have any knowledge, is contained in a letter describing the habits of the black bass, written by Mr. John Eoff, of Whecling, West Tirginia, and published in the Report of the Smithsonian Institution for 185t, and is as follows:

"Mr. William Shriver, a gentleman of this place, and son of the late David Shriver, Esq., of Cumberland, Maryland, thinking the Potomac River admirably suited to the cultivation of the bass, has commenced the laudable undertaking of stocking that river with them; he has already taken, this last season, some twenty or more in a live-box, in the water-tank on the locomotive, and placed them in the canal basin at Cumberland, where we are in hopes they will expand and do well, and be a nucleus from which the stock will soon spread."

General Shriver, himself, in a letter to Philip T. Tyson. of Baltimore, Agricultural Chemist of Maryland, in September, 1860, says:

“* * The enterprise or experiment was contemplated by me long before the completion of the Baltimore and Ohio Railroad to the Ohio River at Wheeling, but no satisfactory mode of trans- 
portation presented itself to my mind until after the completion of the great work (in, I believe, the year 1853), and in the following year I made my first trip (although I made several afterwards in the same year), carrying with me my first lot of fish in a large tin bucket, perforated, and which I made to fit the opening in the water-tank attached to the locomotive. which was supplied with fresh water at the regular water stations along the line of the road, and thereby succeeded well in keeping the fish (whicin were young and small, having been selected for the purpose) alive, fresh, and sound.

"This lot of fish, as well as every subsequent one, on my arrival at Cumberland, were put into the basin of the Chesapeake \& Ohio Canal, from which they had free egress and ingress to the Potomac River and its tributaries, both above and below the dam.

General Shriver also states in a subsequent letter to Dr. Asa Wall, of Winchester, Tirginia, dated September $1 \%$, $186 \%$ :

"The number of these black bass taken to the Potomae River by me, as well as I can now recollect, was about thirty. ***"

Mr. Edward Stabler, a well-known and reliable gentlcman of Maryland, in a letter to G. T. Hopkins, of the Board of Water Commissioners of Baltimore City, dated, "Baltimore, 10th Mo.. 28. '65," and published in the "Baltimore Sun" during the same month, says:

"After much delay and frequent disappointments and loss, from the lack of suitable transportation, I have succeded in taking in the upper Potomac, and safely transporting to Baltimore, a fine lot of 'black bass' [small-mouth], with which to stock 'Swan Lake,' and also those in Druid Hill Park.

"As a brief history of the introduction of this superior fish into the tributaries of the Chesapeake, and east of the Alleghanies for they are, in my opinion. before the trout. both for sport and the table - may not be without interest to some. it may be stated that some thirteen years since, my son, A. G. Stabler, then a con- 
ductor on the Baltimore \& Ohio Railroad, in connection with two public-spirited gentlemen of Wheeling (Forsythe and Shriver), brought from Wheeling Creek, West Virginia, a small lot of bass in the water-tank of his tender. They were placed in the Potomac, near Cumberland, and from this stock, the Potomac, for more than two hundred miles, and all its large tributaries - the Seneca, Shenandoah, Cherry Creek, Sleepy Creek, Great and Little Cacapon, Patterson's Creek, South and North Branch, etc.- afford fine fishing.

"They are, I know, from the Great Falls to a considerable distance west of Cumberland, for I have recently so taken them, and often weighing from five to seven pounds - from four to five pounds is not unusual. * * * "

The "Baltimore American" in June, 18\%t, in an article on Fish Culture, remarked incidentally:

"It was twenty years ago, that Alban G. Stabler and J. P. Dukehart, together with Forsythe and Shriver, brought a small lot of black bass in the tender of a locomotive from Wheeling Creek, West Virginia, and put them in the Potomac. From this small beginning, sprang the noble race of fish which now swarm in the river."

It is certain from the above evidence, that General Shriver was the leading spirit in the enterprise, assisted, no doubt, by Mr. Forsythe, of Wheeling, and Mr. A. G. Stabler, of Baltimore. The latter gentleman, being the conductor of the train which carried the bass - and there is no evidence showing that more than one lot was taken certainly had some share in the transaction; and if he was a "chip off the old block" - for his father, above-mentioned, was an enthusiastic angler — it would naturally be expected that he would have taken a lively interest in the affair.

The circumstance is one in which I have always felt the greatest interest, for it occurred at the time when I first 
left my native city of Baltimore for a home in the west; and $I$ have a distinct impression of the matter, made at the time of its occurrence, either from having heard it frequently spoken of, or from reading accounts of it in the public prints of the day; and my early impressions have always connected the name of Mr. Stabler, then a conductor of the Baltimore \& Ohio Railroad Company, with the praiseworthy act.

At all events, it excited my curiosity as to the black bass, which I had then never seen, and prompted me tn seek the aequaintance of that grand game-fish, which I very soon afterward proceeded to do, in the Miami River, near Cincinnati. It is scarcely necessary to say that I have ever since been on terms of the closest intimacy with him, he having almost supplanted, in my affections, the love I once bore my former piscatorial friends, the striped bass, the blue-fish, and the white perch of the Chesapeake and the Patapsco; but I must confess to an occasional retrospective weakness, and a kindly yearning for the old-time friends of my boyish days, not excepting the diminutive, but delicious "gudgeon" of the upper Patapsco and Herring Run. 


\section{CHAPTER VI.}

HABITS OF THE BLACK BASS.

“*** they mutually labor, both the spawner and the melter, - to cover their spawn with sand,- or, watch it,- or hide it in some secret place, unfrequented by vermin or by any fish but themselves."- IzaAK WALTON.

\section{SPAWNING AND HATCHING.}

BLACK B.Ass are very prolific, the females yielding fully one-fourth of their weight in spawn, or from two thousand to twenty thousand eggs, according to age and weight. The eggs are of the athesive or glutinous class, and can not be manipulated in the same way as those of the salmon, trout, or shad (which latter are non-adhesive and separate) by the fish culturist. 'The eggs are inclosed or enveloped in a glutinous matter of an adhesive character, which sinks at once to the bottom of the nest and become glued to the pebbles, rocks, sticks, etc.

The period of spawing extends from early spring to midsummer, according to the section of country, and temperature of the water, and without regard to species; in the southern states occurring as early as March, and in the northern states and Canada, from the middle of May until the middle of July, always earlier in very shallow waters, and somewhat later in those of greater depth.

In Waukesha County, Wisconsin, I observed a difference of from one to four weeks in the time of spawning, in the numerous lakes of that locality, owing to the difference in temperature of said lakes, caused by their varying depths.

The bass leave their winter quarters in deep water about 
a month or six weeks previous to the spawning season, at which times they can be scen running up streams and in the shallow portions of lakes, in great numbers. Soon afterward, the males and females pair off and prepare for breeding. Owing, seemingly, to a semi-migratory habit, and where the conditions are not favorable for them to ascend the inlets of lakes, they will descend outlet streams if the lake does not furnish suitable spawning grounds.

They select farorable spots for their nests, usually upon a gravelly or sandy bottom, or on rocky ledges, in water from eighteen inches to three feet deep in rivers. and from two to six feet deep in lakes and ponds, and, if possible, adjacent to deep water, or patches of aquatic plants, to which the parent fish retire if disturbed.

The nests are circular, saucer-like depressions, varying from one to three feet (usually about twice the length of the fish) in diameter, which are formed by the male fish, usually, by fanning and scouring from the pebbles all sanrl, silt, and regetable debris, by means of their tails and fins, and by removing larger obstacles with their mouths. This gives to the beds a bright, clean, and white appearance, which in clear water can be seen at a distance of several score yards. I have seen hundreds of such nests, in groups, almost touching each other, in the clear-water lakes of Wisconsin, Michigan, and Minnesota.

Sometimes the nests are formed upon a muddy bottom, with a parement or foundation of small sticks and leares, from which the mud and slime have been washed and scoured; and especially is this the case with the largemouth bass, which will also make its nest upon the roots of water plants.

The females deposit their eggs on the bottom of the nests, usually in rows, which are fecundated by the male 
and become glued to the pebbles or sticks contained therein. The eggs are hatched in from one to two weeks depending on the temperature of the water, but usually in from eight to ten days.

When hatched, the young bass are almost perfectly formed, from one-fourth to one-half of an inch in length, and cover the entire bed, where they can be easily detected by their constant motion. After hatching, the young fry remain over the bed from two to seven days, usually three or four, when they retire into deep water, or take refuge in the weeds, or under stones, logs, and other hidingplaces.

During the period of incubation the nests are carefully guarded by the parent fish, usually by the males, who remain over them, and by a constant motion of the fins, (reate a current which aerates the eggs and keeps them free from all sediment and debris. After the eggs are hateher, anc? while the young remain on the nests, the vigilance of the parent fish hecomes increased and unceasing, and all suspicious and predatory intruders are driven away.

Their anxiety and solicitude for their erges and young, and their apparent disregard of their own safety at this time, is well-known to poachers and pot-fishers, who take adrantage of this trait and spear or gig them on their nests. They also take them with the minnow or crawfish. Of course the bass do not "bite" at this season, voluntarily, but when the hait is persistently held under their noses, they at first endeavor to drive it away or remore it from the nests, and finally, I think, swallow it in sheer desperation.

Major Isaac Arnold, Jr., while in command of the Arsenal, at Indianapolis, Indiana, prepared a small pond in 
the grounds and stocked it with small-mouth bass from White River and Fall Creek. For sereral year's he had the opportunity of closely observing the fish during the breeding season, and records the following interesting data:*

"I placed the bass in the pond for the sole purpose of noticing them during the breeding season, but the water in the pond was so crowded with a growth of algæ that my observations have not been satisfactory. I think the female prepares the spawning ground or bed, after which the male joins her. Whilst the female is preparing the bed the males fight with each other for possession. * * * The male presses the roe from the female by a series of bites or pressures along her belly with his mouth, the female lying upon her side during the operation. The male ejects the milt upon or over the roe from time to time, and the spawning process lasts for two or three days. When the spawning is over, the male disappears from the scene, and the female remains upon the nest extremely pugnacious, allowing nothing to approach until the eggs have hatched and the young fry are a week or ten days old. The young fish commence at once to prey upon each other and continue until they are two or three weeks old, when cannibalism ceases and there is no more danger from that source."

This accords, in the main, with my own observations, though I have never observed the male biting or pressing the abdomen of the female with his mouth; this feature, however, has been confirmed by Mr. Geo. C. Rixford, of Rixford, Florida, who observed the occurrence in that state. It would seem, then, that this proceeding is not uncommon to both species, as Major Arnold's observations were confined to the small-mouth, and those of Mr. Rixford to the large-mouth bass.

I have often seen the female alone, and sometimes the male, and sometimes both together, spinning rapidly

* Successful Propagation of Black Bass. By Major Isaac Arnold, Jr., U. S. A. < Bulletin U. S. Fish Commission, Ir, 1882. 
around the nest, upon their sides, ejecting the eggs or milt, which sank at once to the bottom. When the fish were in pairs, the edges of their bellies would be toward each other, sometimes in contact, as they circled around quite close to the bottom, with jerky, tremulous motions; but I never saw the male pressing the spawn from the female with his mouth.

I record the following interesting item for the benefit of future olservers. My own opinion is that such nests are constructed in lakes of considerable depth, with steep) shores, where suitable bottom in shallow water can not be found, and the bass resort to this expedient for the purpose of bringing the eggs within the proper distance of the surface in order to ohtain light and air. "Homo," of Philadelphia, thus writes to "Forest and Stream :"

"While in Grand Rapids, Mich., during my late vacation, I was informed by Dr. Parker, of the State Fish Commission, and a Mr. Hill, of that city, of a new feature in the habits of the black bass during spawning time, which had come under the notice of those gentlemen. It was that of the nest builling of these fish within two or three feet of the surface in ten and fifteen feet of water. Mr. Hill told me he had frequently observed, at the head of some lakes and ponds in Michigan, a collection of ring moss and other vegetable matter, placed with apparent design on the top of brush heaps which rested on the bottom of the lake and extended nearly to the surface of the water. Not knowing what they were, he made a critical examination and found them always guarded by the bass which had constructed the nest in the same manner in which they protect their ordinary nests made in the bed of the stream or pond. In many cases the nests would be three or four feet in diameter and larger than the top of the brush pile on which they rested. This habit of the hass I have never heard of before, and both Mr. Hill and Dr. Parker confessed they had never seen an account of it published. It may be some of your correspondents know of it and ean give further light on the subject. May it not be that some peculiar character of the bed of these 
boclies of water, where the nests are found, renders it impossible for the spawn of the fish which inhabit them to properly develop if deposited there, and the nest building is resorted to to aid in a better or more speedy hatching of the eggs? Perhaps more sunlight is wanted. I am at a loss to give a better explanation of the matter."

The U. S. Bureau of Fisheries and the Fish Commissions of several states have been experimenting for some years in the pond culture of black bass; in most instances by furnishing artificial nests of various kinds, in which the bass spawn. When the fry rise from the nest they are inclosed by screens or netting and subsequently removed to nursery ponds. This plan has not yet been attended by extraordinary success. The most practical way, so far, is to stock new waters with the parent fish and allow them to breed naturally. It is to be hoped, in view of the great demand for small black bass for stocking purposes, that the artificial plan mentioned, or some other, may be crowned with complete success.

About 1868 to $18 \% 0$, while residing in Wisconsin, I experimented with the natural propagation of the black bass, by placing a number of adult fish of both species in a pond on my home grounds, which I connected with a lake by a roomy ditch. From blinds of bushes on the banks I watched, faithfully, the nesting and spawning of the fish forr sereral seasons. A few days after the fry left the nests the parent fish were driven out of the pond and through the ditch into the lake. Suitable screens were then placed in the ditch and the young bass were kept until late in the autumn, when they too were turned into the lake. I reared many thousands each season in this way, which was but a slight modification of nature's plan. 


\section{Food And Growth.}

After the young bass leave the spawning beds their food at first consists of minute crustaceans; and later of insect larve; as they grow older and larger they devour worms, tadpoles, small fish, etc.; and, in later life, they vary their diet with crawfish, frogs, mussels, and minnows, until, attaining a weight of two pounds, they will bolt any thing from an angle-worm to a young musk-rat.

Dr. S. A. Forbes, of the Illinois State Laboratory of Natural History. was engaged, for a number of years, in the study of the food of fishes and birds. His examinations have been of the most careful and painstaking character. The following results have been attained in reference to the food of the black bass species.*

Of the large-mouth black bass he examined the food of fourteen adults and serenteen young of different ages. The first group, consisting of five specimens under one inch in length, taken in June, July, and August of different years, showed that the entire food consisted of minute crustacea, all Entomostraca, except in the case of a single fish, which showed seven per cent. of a rery young amphipod.

Six specimens, from one and a fourth inches to one and a half inches long had eaten minute fishes (twenty-nine per cent.) and insects (forty-six per cent.), the crustacea dropping to twenty-five per cent. The fishes eaten were not large enough to determine the species. Two specimens between two and three inches long had eaten only insects. Four specimens varying from three to three and one-half inches in length had eaten nothing but insects and their larræ. In the fourteen adults the food consisted of seven.

* The Food of Fishes. By S. A. Forbes. < Bulletin III, Ills. State Lab. Nat. Hist., 18, 1880. 
per cent. of crawfishes, a few insects, and eighty-six per cent. of small fishes.

In regard to the small-mouth bass, Dr. Forbes says:

"I have made full notes of the food of twenty-seven specimens - three adult and the others young. I had none of these species under an inch in length, but, judging from the general resemblance of the food of this and the preceding bass at later ages, I do not doubt that this will also be found to feed at first on Entomostraca, although insect food is possibly more important to it from the beginning."

Seven small-mouth bass, from one to two inches in length, had eaten only five per cent. of Entomostraca, the remainder of the food consisting of insects and their larvæ. 'Ten specimens, between two and three inches long, showed, in addition to the insect food, five per cent. of fishes, and in those ranging from three to four inches in length the amount of fish food increased to fourteen per cent., the insect food dropped to seren per cent., with serenty-nine per cent. of crustacea. The three adults had eaten thirty-eight per cent. of fishes and sixty-two per cent. of crawfishes.

Some allowance should be made for the character of the different waters in which the specimens were collected, as Entomostraca and other minute crustacea are more abundant in still water, while the larræ of certain insects are more plentiful under the stones of rapid streams.

Where food is plentiful the young grow rapidly, reaching a length of two inches in a few months after hatching, and at a year old, will measure, at least, four inches. At two years of age, they will be found from eight to twelve inches in length, weighing about a pound, and will grow nearly or quite a pound a year thereafter, until they attain their maximum weight.

They arrive at maturity in from two to three years, ac- 
cording as to whether the conditions for their growth were favorable or otherwise. The maximum weight of the smallmouth form of the north and west may be said to be four or five pounds, and of the large-mouth form, from six to eight pounds, though there are rare exceptions to this rule.

In the warm waters of the southern states, which preserve a more equable temperature than those of the northern states, the large-mouth black bass grow to an immense size, their maximum weight, in Florida, being from twelve to fifteen pounds.

In northern waters they do not grow nearly so large, six to eight pounds being the limit. Under conditions and circumstances farorable to their growth they will increase in weight, as before stated, about a pound a year; but under adverse circumstances or unfavorable conditions their growth is much slower; therefore, no rule of general application ean he estallished from any single instance, or as the result of any exclusively local test or experiment.

The growth of black bass is affected not only by the supply of food and temperature of water, but also by the extent of range. Bass in small ponds do not thrive so well, nor grow so fast; the smaller the extent of their range, the slower will he their growth, and, indeed, this is true of any other fish; for it is well known that fish confined in aquaria, in springs or wells. grow so very slowly, that their increase in size is hardly appreciable from year to year, even though their supply of food be abundant.

An equally well-attested fact is that the largest bass are found in the largest bodies of water, or where the range is extensive; extreme depth of water seeming to be more favorable to their growth than mere extent of surface. For example, I know of several shallow lakes in Wisconsin, where the hass seldom grow to exceed two 
pounds, while in deeper lakes in the same vicinity they attain the usual maximum weight of four or five pounds; and in Green Lake, a large and deep lake near Ripon, in the same state, I once caught a string of thirty black bass, mostly of the large-mouth species, weighing from four to eight pounds each, and fully averaging six pounds.

An instance, showing the rapid growth of black bass, is related by Mr. Charles J. Pearson, at that time Fish Warden for Morris County, New Jersey: He states that in the fall of $18 \% 6$, fifty black bass, measuring from two and a half to four inches in length, were placed in D. L. Miller's pond at Madison, Morris County, New Jersey. On October 1\%th, $18 \% \%$, about one year from the time of putting them in, Mr. Miller had occasion to draw the water down, for some repairs. He had the flume so arranged as to take any fish that might run out. Eleven bass were caught. They measured from ten to thirteen inches in length, and were undoubtedly the same fish which were put in the year before, as none of this species of fish were ever known in the pond before.

There is not an absolute uniformity of growth in fishes, any more than in other creatures; thus, some fish will outgrow others of the same hatching until double their size, a fact made very apparent in the artificial culture of brook trout, salmon, etc.; but black bass will grow with wonderful rapidity where an equable temperature of water and an abundance of food obtain. As an instance of the influence of an abundant supply of food upon the growth of black bass, A. N. Cheney, of Glens Falls, New York, related to me the following circumstance, and presented me with a fine photograph of the two fish alluded to:

"I send you a photograph of two large-mouth bass caught by myself. They are, or, rather, one of them is, the largest bass 
ever caught in any waters about here, weighing seven pounds and fourteen ounces, and the other six and a quarter pounds. The most remarkable fact is, perhaps, the effect of food upon the growth of fish. The two fish in question were caught in Long Pond, near here, August 1, 1877. Long Pond was stocked with six small bass from Lake George, New York, in 1866, they having been put into a stream emptying into the pond by some gentlemen, who, on their way from camping a week at Lake George, had to cross this stream to reach home; and the putting the fish into the stream was suggested by their catching a number of small bass during the last day in camp.

"The fact of their deposit was almost forgotten, when, in 1874-75, quantities of bass were discovered in the pond, which had hitherto been inhabited by pickerel, pereh, and quantities of bait fish, minnows, silver and gold shiners, ete. While Lake George has never been known to yield a bass over six and a half pounds, Long Pond has turned out at least a dozen over that weight."

Upon a careful examination of the photograph, the fish mentioned were found to be, not large-mouth, but smallmouth bass without any doubt, and were extraordinary examples of that species, the usual maximum weight of which is about five pounds. Afterward Mr. Cheney recorded the capture of several more of these small-mouth giants from the same watrers (Long Pond, or Glen Lake).

One of them, taken by a Mr. Reed, was seen and weighed by Mr. Cheney, who gave its proportions as follows: weight, eight and one-quarter pounds; length, from end of snout, to fork of tail-fin, twenty-two and one-half inches; girth, eighteen and one-half inches. Mr. Fred Mather saw this fish and pronounced it a small-mouth bass.

The other and larger fish was captured in the same waters by a Mr. Boynton. Mr. Cheney weighed and measured it and gave its weight as eight pounds and ten ounces, its extreme length as twenty-five inches, and its girth eighteen and three-fourth inches. 
Following this several more immense small-mouth bass were taken from the same waters and recorded by Mr. Cheney, who tabulated them as follows:

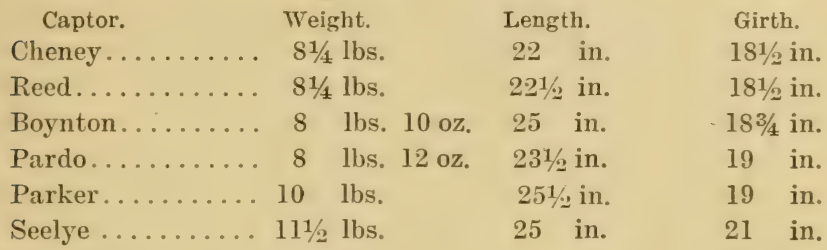

Mr. Cheney commenting on the above said:

"I weighed and measured Reed's, Boynton's, Parker's and my own fish; the other figures were given to me by the people who caught the fish and confirmed by witnesses."

In preparing tables of exact measurements of the two species, as also tables showing the relative weight as to length, I found so much discrepancy in these respects in the same species from different localities, and even in fish from the same section, owing to slight variations of shape and conformation, that I concluded they would not subserve the purposes of a general guide, and so omitted them. This reason is very apparent as exemplified in the following list of fish from contiguous waters.

The "Toronto Star" offered a prize of a fifteen-dollar rod to the angler taking the largest small-mouth bass in the province of Ontario, Canada, during the summer of 1903, the competition to close on September 15th. The fish entered for the prize, and which were all from lakes, except the last, a stream fish, were as follows:

$\begin{array}{lll}\text { Length. } & \text { Girth. } & \text { Weight. } \\ 23 \text { in. } & 17 \text { in. } & 7 \text { lbs. } \\ 21 \text { in. } & 17 \text { in. } & 6 \mathrm{lbs} .4 \mathrm{oz} . \\ 223 / 4 \text { in. } & 15 \frac{\mathrm{l}}{4} \mathrm{in} . & 6 \mathrm{lbs} .1 / 2 \text { oz. }\end{array}$




\begin{tabular}{|c|c|c|}
\hline Length. & Girth. & Weight. \\
\hline 20 in. & 14 in. & $6 \mathrm{lbs}$. \\
\hline 22 in. & 17 in. & 5 lbs. 14 oz. \\
\hline $191 / 2$ in. & 16 in. & 5 lbs. $9 \mathrm{oz}$. \\
\hline $221 / 2$ in. & $141 / 2$ in. & 5 lbs. 8 oz. \\
\hline 21 in. & $141 / 2$ in. & 5 lbs. $8 \mathrm{oz}$. \\
\hline 20 in. & 17 in. & 5 lbs. $8 \mathrm{oz}$ \\
\hline 21 in. & 18 in. & 5 lbs. $71 / 2 \mathrm{oz}$. \\
\hline $215 / 8$ in. & $151 / 2$ in. & 5 lbs. 7 oz. \\
\hline 22 in. & $161 / 2$ in. & Ј los. $6 \mathrm{oz}$. \\
\hline $207 / 8$ in. & & 5 lbs. $3 \mathrm{oz}$. \\
\hline $195 / 8$ in. & $141 / 2$ in. & 5 lbs. $3 \mathrm{oz}$ \\
\hline 20 in. & 15 in. & 5 lbs. \\
\hline $201 / 2$ in. & $13 \frac{1}{2}$ in. & 4 lbs. 14 oz. \\
\hline $193 / 4$ in. & 14 in. & 4 lbs. $13 \mathrm{oz}$ \\
\hline 21 in. & $141 / 2$ in. & 4 lbs. $12 \mathrm{oz}$ \\
\hline $181 / 2$ in. & $121 / 2$ in. & 4 lbs. 12 oz. \\
\hline $211 / 2$ in. & $143 / 4$ in. & 4 lbs. $9 \mathrm{oz}$. \\
\hline $211 / 2$ in. & 16 in. & 4 lbs. 8 oz. \\
\hline 20 in. & in. & 4 lbs. 4 oz. \\
\hline $201 / 2$ in. & $14 \frac{1}{2}$ in. & 4 lbs. 2 oz. \\
\hline $181 / 2$ in. & & 3 lbs. 9 oz. \\
\hline
\end{tabular}

Mr. H. IV. Ross, when in Florida, caught, in a "clear, deep, lily-bound lake," near Altoona, in that state, a largemouth black bass which, he stated, weighed twenty-three and one-eighth pounds, and measured, from tip of nose to tip of tail, thirty-seven and one-half inches, and in girth, twenty-nine and one-half inches. The head of this fish was sent to the office of "Forest and Stream," in New York, and its dimensions were given by the editor as follows :

"Its maxillary bone measures four and three-fourths inches; the head is seven and one-half inches from the tip of the upper jaw to the end of the opercle, and the lower jaw projects one inch. The greatest girth of the head is sixteen and one-half inches." 
I have taken the large-mouth bass in Florida up to fourteen pounds on the artificial fly, and as heary as twenty pounds with bait. It is obvious that where the largemouth black bass does not hibernate, as in Florida, and is active all the year and constantly feeding. its size and weight will be much greater than in northern waters.

\section{Hibernation.}

Black bass undoubtedly hibernate, except in the extreme southern and south-western states; but in the colder climate of the north and west it has been proven in numerous instances that they bury themselves in the mud, in the crevices of rocks under masses of weeds or sunken $\operatorname{logs}$, in the deepest water, and remain dormant until spring.

This halit has been doulted by some. inasmuch as an occasional bass has been caught through the ice. though such instances are rare indeed, and all those of which I have any knowledge occurred late in the winter. or early in the spring. As one swallow thes not make a summer, these unusual cases must be considered as merely exceptions to the general rule.

During a residence of ten years in Irisconsin, where fishing through the ice was constantly practiced during the winter, and where tons of pickerel, pike-perch and yellow-perch were so taken in a single season. I never knew of a single black lass being taken in that manner except very late in the winter, or in early spring, say in March, just before the breaking up of the ice; and even those instances were of rare occurrence, and happened only during unusually mild weather: and these same waters, be it remembered, afforder the finest black bass fishing during the summer and fall. 
Dr. D. C. Estes, of Lake City, Minnesota, an accomplished angler and naturalist, records a similar experience in regard to Lake Pepin; he says:

"The pike and pickerel are the only fish taken here in the winter. It is strange to many what becomes of the countless numbers of other game fish that throng these waters in the summer season. Bass, which are so numerous then, are never seen in winter. I an quite sure that not a single bass was ever caught here through the ice. I have for years tried all depths of water to raise one, or to discover one, but have thus far failed. I must believe, then, that they hibernate."

Genio C. Scott, in "Fishing in American Waters," quotes an intelligent and reteran black bass angler of central New York, in regard to this habit, and who furnishes the following conclusive evidence:

"I have never known them [black bass] to be taken in winter, and $I$ think they seek a particular location and remain torpid during winter. My attention was directed to this fact about thirty years since. At that time I was in the haibt of spearing fish in a mill-dam on the outlet of Seneca Lake, at Waterloo, Seneca County, New York. From April to November I found numbers of bass: from December to Narch I found all other varieties, but no bass.

"In the winter of 1837 , the water was shut off at the lake for the purpose of deepening the channel to improve the navigation. This was considered a favorable time to quarry the limestone in the bed of the river; and upon moving the loose rock in the abovenamed mill-dam, where the ledges cropped out, there were found hundreds of bass imbedded in their slime, and positively packed together in the crevices and fissures of the rocks. My subsequent experience has done much to convince me that my theory is correct."

On this point, A. N. Cheney related to me the following incidents :

"A few years ago a man, Seth Whipple, living on the Hudson River, near Glens Falls, in drawing some sunken logs from the 
river, during the winter, for firewood, found in the hollow of one of the logs, six black bass (small-mouth), weighing from a half to two pounds; they were nearly dormant.

"The father of Pension Commissioner Bentley. who lives at Glens Falls, and has some trout ponds on his place, to gratify a boy bought of him a black bass, and placed the fish in a spring. When autumn came the fish was missing, and was supposed to be stolen. During the succeeding winter the spring partly dried up, and to restore the water supply the spring was dug deeper. During the operation it was found necessary to remove an old stump in the side of the spring, when to his surprise the bass was found underneath the stump, in a hole, evidently prepared for winter burrow."

Mr. John Eoff, of Wheeling, West Virginia, a remarkably close observer, says, in the "Report of the Smithsonian Institution," for 1854:

"In the winter season they retire to deep and still water, and apparently hide under rocks, logs, etc., and remain there until the first of April."

I could multiply evidence on this point, if necessary, but these several opinions, founded upon observations made in the widely separated states of Wisconsin and Minnesota in the west, New York in the north, and West Virginia in the middle section of our country must suffice.

That black bass do not hibernate in the extreme south, is well known; and to this circumstance, may be attributed, in a measure, their larger growth. Still, it is not unreasonable to suppose, that the black bass of that section have a period of repose and seclusion, analogous to hibernation, at some other season of the year, possibly during the fervid heat of the summer solstice; for it is usual for the bass of the north and west to cease biting and retire to the deepest water during an unusually heated term in summer. The fact that the best season for black bass fishing varies 
in different sections - in the north being from July till October; in the west and most northerly of the southern states in the spring and fall; and in the extreme south during the winter season - would naturally lead one to suppose that the period of dormancy in the black bass occurs at different seasons in different localities, and is influenced by climatic conditions, or the supply of food.

But, notwithstanding the evidence heretofore adduced in support of this fact, the occasional catching of a black bass during the winter season, in the north and west, is sometimes heralded as a proof that former observers have been mistaken, and that these fishes, or at least the largemouth bass, do not hibernate.

Perhaps the term hibernation is not well understood, which may aceount for this hasty and erroneous conclusion. Hibernation does not necessarily imply, as supposed by some, a state of complete torpidity or profound sleep during the entire winter. 'To hibernate, according to Webster, is "to pass the season of winter in close quarters. or in seclusion;" and that is just what the black bass of both species do, in northern and western waters, as every one who has given the subject any intelligent investigation is prepared to admit.

When the temperature falls as low as $50^{\circ}$, the bass of running streams retire to the deepest holes, in the neighborhood of shelving rocks, if possible, under which they seclude themeclres and remain in a listless condition. So also, in lakes or ponds, they leave their accustomed haunts, and retire to the deepest places, near bottom springs, masses of weeds, moss, etc. After a few days of warm or mild weather, especially if the temperature goes above $50^{\circ}$, they will venture out into water of somewhat less depth, when they may be induced to take a bait in a half-hearted 
manner, while the mild weather lasts; but, on the approach of a cold snap they again retire to the deepest water. When the temperature rises above $50^{\circ}$ - say to $55^{\circ}$ - and does not fall below again, they leave their winter quarters for that season.

From personal observation I am pretty familiar with the habits of both species of black bass, at all seasons of the year, in all sections, except in the New England states, and I am convinced that, with the exception of those in the Gulf states, both species of black bass hibernate in a greater or less degree, according to the temperature of the waters.

The small-mouth bass of western Lake Erie hibernate under the ledges and cavernous reefs about the Bass Islands. In the spring, after the first fine weather in April or May, when emerging from their winter quarters, they linger on the reefs and bite ravenously for a week or two, or may be two or three weeks, until the weather becomes still warmer, when they cease biting suddenly and depart toward their spawning grounds, wherever that may be, for they certainly do not spawn in the deep water on the reefs.

After the cold northeast storms in September they again congregate on the reefs, preparatory to going into winter quarters, and bite until cold weather sets in, when they disappear under the ledges and reefs. A few stragglers, however, remain during the summer and spawn in the coves about the islands, but the main army seck other grounds more suitable for procreation, and where the food for the voung bass is more plentiful. 


\section{CHAPTER VII.}

\section{INTELLIGENCE AND SPECIAL SENSES.}

Venator. But, master! do not trouts see us, in the night?

Piscator. Yes; and hear, and smell, too, both then and in the day-time.-IzAaK WALTON.

Tre brain of fishes differs so materially in size, conformation, substance and analogy from that of other animals, that it has been the rule of specialists to attribute to this class of vertebrates a very low order of intelligence. In opposition to this theory, however, Dr. Francis Day, in a paper read before the Linnæan Society of London, England, endearored to show that fishes possessed a far higher order of intelligence than is usually accorded them.

He claimed that the experience of himself and others indicated that they possessed emotions and affections, and in smpport of that view he showed that they constructed nests, transported and defended their eggs, protected their young, manifested their affections for each other, recognized human beings, could be tamed, exhibited the cmotions of fear, anger, and revenge, uttered somnds, hid from danger, sought protection by attaching themselves to the bodies of other animals, and had peculiar modes of defense; that they left the water in scarch of fool, and that they sometimes combined for attack and defense.

Every observant angler and naturalist has, in his own experience, prover the truth of many of the above assertions, and. no doubt, some have observed traits of intelligence still more convincing.

The wonderful faculty of anadromous fishes. seeking out and ascending their native streams during the breeding 
season, even after being purposely carried hundreds of miles away, has commanded the admiration of biologists, yet they can see nothing in the small and jelly-like brain of the fish to account for the marvelous habit, but instinct; on the same principle, perhaps, that Coleridge accounts for the blindness of Love:

\section{"His eyes are in his mind."}

\section{Sense of Sight.}

As the optic nerres of fishes show an extraordinary derelopment, we must naturally conclude that they are as sharp-sighted in their element as we in ours. This, I think, no experienced fly-fisher will deny; yet it is the fashion for biologists to accord to fishes only a moderate risual capacity, as compared with land animals. But good, simple old Izaak Walton was much nearer the truth when he said: "A trout that is more sharp-sighted than any liawk you have named, and more watchful and timorous than your high-mettled merlin is bold."

"In the range of their vision and acuteness of sight," says Dr. Günther, "fishes are rery inferior to the higher classes of rertebrates; jet, at the same time, it is evident that they perceive their prey or approaching danger from a considerable distance."

We are led to believe, from the investigations of anatomists, that the organs of special sense in fishes are very imperfectly developed; I am constrained to helieve. however, from the observations of myself and many others, that fishes have the senses of sight, hearing, and smell dereloped in a much greater degree than is generally supposed.

The dirersities in form and position of the eyes of 
different fishes, prove that they are of the greatest use to them, in procuring food, and in escaping from their enemies; and are placed "where they will do the most good."

In the majority of fishes, which are constantly moving about, and frequent alike the surface and bottom of streams, the eyes are placed in the usual position of most other animals, one on each side of the head. In those which stay more constantly in the lower depth of waters, the eyes are placed on top of the head, as in the star-gazers; while in the flat fishes, which recline or swim on one side near the bottom, both cres are placed on the same side of the head, enabling them to obtain the benefit of both eyes while in that position. In the pike-perch, which is nocturnal in its halits, the eyes are unusually large, as is the case with other animals who seek their food mostly at night.

It is a popular idea that fish are necessarily near-sighted on account of the conformation of the eye, which is large, round and prominent: and the main argument adduced to support this theory, is the readiness with which they will take an artificial fly, trolling spoon or other artificial bait, which resemble in but slight degree the natural objects of food that they are intended to represent, if, indeed, they are intended to represent any thing.

It is often the case that those anglers who are most strenuous in their theory that fish are near-sighted, stultify themselves by carrying a large and most varied assortment of artificial flies, of all shapes and colors, in order to meet the "fasticlious taste" of the fish, that often refuse one pattern or color, and rise eagerly to another, which could not he the fact were they so near-sighted as they believe. The consistener of these anglers would be more apparent, if they would adopt Mr. Cholmondely Pennell's theory of 
artificial fiies, and confine themselves exclusively to his three typical flies - brown, yellow, and green hackles.

Now, I am not of those who believe that our brave game-fishes possess such extreme gullibility, as to mistake an artificial lure for the genuine article, upon the hypothesis of near-sightedness. My opinion, founded upon numerous experiments, is, that fishes see and hear as well, in and through the medium of the water, for all practical purposes, as the angler does through the medium of the atmosphere; the clearer and more rarified the medium, the clearer and greater the range of vision in both instances.

In muddy or turbid waters the sight of fishes is necessarily limited, as ours would be in hazy or foggy weather. It is neither fair nor logical to presume that fishes, in water, ought to discern objects in the atmosphere above, sny clearer or plainer than we can perceive objects in the water, while standing on the brink.

We are altogether too prone to judge evenything from our own standpoint, and to attribute to our own cleverness results that in all probability depend upon other and extraneous circumstances. Who, of us, could tell a skillfully tied artificial fly from a real one, beneath the water, when its surface was ruffled by a brisk breeze, shadowed by drifting clouds, corered with the froth and suds of an eddy, or surmounted by the foam and bubbles of a rapid?

Yet, there are those who contend, because fish fail to detect this difference through the same obstacles to clear vision, that they are of a verity near-sighted, and easily fooled by the very poorest semblance of a fly or feathery nondescript; but let one of these persons try a cast of the best flies upon a bright, still day, when the water is perfectly clear and the surface like a mirror, and if he expects 
to get a rise under such conditions, he himself must be very near-sighted indeed.

On the other hand, any one who has seen a black bass dart like an arrow and seize a minnow swimming quietly thirty feet away, or a brook trout flash like a meteor for a dragon fly hovering near the water at the same distance, must admit that their risual powers are sufficient for al! practical purposes.

It is quite amusing to hear an angler expatiate learnedly on the dimness of sight and dullness of hearing in fishes, and in the next breath caution the tyro to have his clothing conform as nearly as possible with the hues of the foliage skirting the stream; to keep out of sight, tread lightly, and make as little noise as possible; and to assure him, that, even then, the chances are that the fish will see the novice before he sees the fish.

It is a curious contradiction of theory and practice, a fishy illustration of the abstract and concrete. The explanation I conceive to be this: our Piscator would be considered a scientific angler, which, in his case, becomes a contradiction of terms; for while blindly holding to the opinions of some closet naturalist, he is practically following the dictates of his own experience and common sense.

Now, it is possible to be scientific and an angler, too, but our science, like our angling, must be practical, and must of necessity be learned by close observation and study of the habits of the fishes as they exist in nature, and not alone from the study of the physical construction of a preserved specimen.

I am well aware that many scientists consider fish myopic, or near-sighted; not, however, on account of excessive convexity of the cornea, as is popularly supposed, for it is an exploded theory in medical science that myopia 
depends necessarily upon this condition; indeed, in fishes the cornea is almost flat, while in birds of prey, which have a very extended range of rision, the cornea is quite convex.

From the lack of analogy, from the great difference in construction of the ocular and auditory apparatuses of fishes and terrestrial animals, and from the wide difference in the properties of the media of air and water, I am conrinced that the organs of the special senses of sight and hearing in fishes are not well understood at the present day; and I am confident that future investigations will prove them to be possessed of much greater acuteness of vision and hearing, than is now accorded them.

Most fresh-water fishes, during the breeding season, take on a more pronounced coloration, the males especially becoming sometimes quite gorgeous in their nuptial dress. If fishes are so defective in sight as not to distinguish color, why this well-known periodical change in their appearance?

It is a well-known fact that fishes are attracted by any gay, bright, or glittering substance, as a finger-ring, a sleeve-button, or a coin, and have deliberately swallowed them when dropped in the water. I have caught brook trout with wintergreen and partridge berries, the bright scarlet color seeming to allure them, and I have eren caught them with a naked bright fish-hook; but all this does not prove that they were the rictims of a myopic mistake, or that in their near-sightedness they mistook these rarious articles for something else; neither does it prove that a black bass will grab at a trolling spoon, a bluefish snap at a bone squid, or a spanish mackerel seize a metal or pearl tioll under the delusion that they are really choice shiners, or delicate piscatorial tidbits.

A camel, it is said, will bolt all sorts of substances, as 
metal, glass, stones, leather, etc., but when were his shortcomings attributed to short-sightedness? Our dogs will often refuse good, clean food and hunt up an old dry bone, a stone, an old shoe, or a stick, and will gnaw them with delight, and even swallow them with evident gratification. Birds will peck at and swallow bright beads, colored threads, etc., and kittens will seize, claw and bite almost any moving small object; but these ragaries are attributed to the idiosyncracies of the animals mentioned, while in fishes they are ascribed to defective sight.

But what are a fish's eyes for? According to our present knowledge they are to enable him to become " a snapper-up of unconsidered trifles" with hooks attached to them!

Now, so far as the artificial fly is concerned, when it is cant lightly upon a fretted surface, I think it is generally taken by a fish under the impression that it is a natural insect; but with regard to trolls of all kinds, as spoons, squids, spinners, propellers, ete., and very often with regard to the artificial fly, I am of the opinion that they are taken through a spirit of mere brarado, curiosity or wantonness, and not with the idea that they are living objects of prey. They are seized by the fish because they are bright, attractive and in motion; not because they are hungry, but because they are in a biting mood, for we often find, nay, most always find, that fish so taken are already gorged with food.

At a meeting of the Manchester Anglers' Association, in England, Dr. A. Hodgkinson gave an address on the "Optics of Angling." which is thus noticed by the "London Fishing Gazette:"

"In considering the subject of angling opties, we are met, as Dr. Hodgkinson pointed out, by the difficulty that we do not 
know exactly what the sight of fishes is, but we must assume it to be not much unlike our orm, and we are not without grounds for the assumption. By drawings on a blackboard, Dr. Hodgkinson showed how the eyes of both men and fishes were alike in their main parts, the greatest divergence being that, whereas the optic nerve in man occupies only a small portion of the brain, in fishes it occupies pretty nearly the whole brain; and we may presume, therefore, that the sight of fishes is more sensitive.

"Dr. Hodgkinson then dwelt with the phenomena of the passage of rays of light from the rare medium air to the dense medium water, and the change in direction that the incident ray undergoes; he pointed out the fact that under certain conditions an angler on the bank might be invisible to a fish in the stream, but the exultation of the gentlemen assembled was probably damped when they heard that, in order practically to discorer the distance they must stand from the water in order to be invisible, they must take their height and multiply it by fourteen, which, as an unfortunate angler who was present pointed out, would require him, seeing that he is six feet high, to stand eightyfour feet from the water's edge before he could take advantage of the invisible mantle Dr. Hodgkinson had promised him. The case, however, is not quite so hopeless as this, for, as the doctor pointed out, the water in which the fly-fisher angles is not generally so smooth as a mirror, and in ripple or broken water it is impossible for fish to see the object on two legs that may be on the bank.

"In fishing for trout, wading in many streams is a necessity, and by means of an ingeniously constructed tank Dr. Hodgkinson showed not only what the angler looked like to the fish when he waded. but how his aspect was affected by the color of the bottom of the river, and that of such cover as there might be on the bank. The rather startling announcement was made and demonstrated, that while the wader was duplicated so far as his legs were concerned, another pair appearing upside down on the actual legs, the man's body, if visible at all, was far away from the legs, and overhead, where, if we put ourselves in the position of the fishes, we should expect to see nothing but sky. No fish then ever saw a wader with his two halves united, and whether its feeble brain can ever connect together the two distinct objects 
- the body up in the air and the legs down in the water - is extremely doubtful.

"The tank by which Dr. Hodgkinson was enabled to demonstrate his theories was made so that from one end the observer could, by directing his vision from various depths of water, always look through a slip of glass placed at right angles to the point toward which he looked. In this way, and by use of a little figure to represent a man, the point where invisibility begins (four degrees) could be clearly seen, as well as the effect which the water has of apparently lifting the object much above the position which it occupies."

\section{Sense of Hearing.}

There is no external ear in fishes, the internal ear alone existing, and which is extremely delicate in its construction.

Dr. John Hunter olserved that it varied much in the different genera of fishes, but that in all it consisted of three curved tubes, which united one with another. The whole organ is composed of a kind of cartilaginous substance, and in some fishes is crusted over with a thin lamella to keep it from collapsing.

The canals terminate in a cavity, in which cavity there is a bone or bones. These ear-bones are familiar to most anglers, and are sometimes rery beautiful, resembling porcelain, and are often called "brain-ivory" those of the sheephisead (Aplodinolus grumnirns) of our western waters are known as "lucky stones," and are highly prized by boys as pocket pieces.

It is the rule among physiologists to say, that while fishes can hear sounds produced in the water, they are incapable of hearing those produced in the air, and even to limit their capacity for hearing accurately those produced in the water. 
Take this, for example, from Mr. Hugh Owen, in "Land and Water:"

"It is exceedingly doubtful if fish possess the faculty of hearing, in the ordinary sense of the term. Mr. Buckland has accurately described the nature of the sensation they do possess, as vibration. There cannot be a doubt that fish have no possible conception of either vicinity, direction, or distance of the vibratory disturbances they receive. A distant vibration disturbs a shoal of fishes as much as a near one; and fish feeding eagerly at the bait will be alarmed and dispersed by the beat of a steam vessel a mile off. All the stories of fish coming to be fed at the sound of a bell or of a whistle are, of course, fables. Such sounds made in the air will not communicate vibrations to the fish beneath the surbace of the water. They assemble only because they see a figure, and are accustomed to be fed upon such occasions."

No angler or fisherman of experience and observation can be made to believe such specious and questional)le statements as the above. He knows better.

As fishes live in a denser medium than terrestrial animals, and one that more readily transmits the waves of sound, we should naturally expect to find a corresponding difference in the construction of the organ of hearing. The iniernal ear of fishes differs nnly in degree, not in kind, from that of the higher animals; they, of course, have no external ear, nor is one necessary in so dense a medium as water; but for this reason it is the fashion to say that they can only hear ribrations communicated through the medium of the water or the shore, the "vibrations" meaning considerable "jars" or "shocks."

"The ear of fishes lies close under the roof of the skull, and is thus easily accessible to the waves of sound, which are conducted partly through the operculum (when present), and partly through the gill slits or spiracle. As we pass to the higher ani- 
mals, however, the auditory organ gradually sinks further and further inward from the surface. Thus a new method for conducting the sound waves is necessitated."-(Wiedersheim.)

"Many Teleostei (true fishes) have fontanelles in the roof of the skull, closed by skin or very thin bone only at the place where the auditory organ approaches the surface, by which means sonorous undulations must be conducted with greater ease to the ear."-(Günther.)

"In many Teleostei a most remarkable relation obtains between the organ of hearing and the air-bladder. In the most simple form, this connection is established in pereoids and the allied families, in which the two anterior horns of the air-bladder are attached to fontanelles of the occipital region of the skull."(Günther.)

The air-bladder, in such cases, may, in a manner, perform the functions of a tympanum.

I append a few sensible remarks from an article by $\mathrm{W}$. N. Lockington, in "Pacific Life:"

"It appears to be not unlikely that fish take no notice of sounds produced in the air, but it is not so easy, unless we can argue the matter from a fish's point of view, to prove they do not hear those sounds. Take the sense of sight as an illustration of that of hearing. I have often amused myself by making believe to strike a monkey that lived in a cage with a glass front. Accustomed to such demonstrations, the monkey simply took no notice. His bright eyes never even winked. Arguing, as was argued in the fish case, I might say monkeys cannot see.

"All fishes have an organ of hearing; not a rudimentary organ, but one complete in its kind, and differing from ours only in its degree of development; differing, in fact, much in the same way that the brain, the heart, the intestines, the skeleton, the skin, the limbs, or any other part of a fish differs from that of a quadruped or from our own.

"The microphone has gone far toward proving what philosophers had previously become convinced of by deductive reasoning, that there is no motion without sound, and therefore that sound is present in numberless instances not evident to our senses. For 
our perception of sound we are dependent upon our sense of hearing, which is adapted only to a certain range of spunds; and this range differs in human individuals, for we all know that some other persons hear sounds imperceptible to us. Still more is this true of other animals; they may hear what we can not, yet be deaf to sounds audible to us.

"Strict experiments upon the hearing of fishes have yet to be made. Most of the observations yet made are faulty, either because, first, the observer has supposed that the fish ought, if it can hear, to notice a sound he makes for the purpose; or, second, he has argued, from the standpoint of his own senses, that if a fish hears, the range of its hearing must be nearly the same as his own.

"To conclude: that fish have ears, is indisputable; that they hear some sounds produced in the water, scarcely admits of question; that they hear some sounds produced in the air, even though they may not take notice of them, is probable, but lacks (so far as I know) experimental proof; that they do not hear many sounds which we hear, or at least do not discriminate between sounds which we, with our more highly organized organs, readily distinguish, is almost certain. All of which ends in this, that fishes hear, but their senses differ in range and delicacy from ours."

A remarkable instance, demonstrating the acuteness of the sense of hearing in fishes, occurred some years ago in California. As it is an exceedingly interesting and wellauthenticated fact, and one so totally at variance with preconceived notions, I feel justified in reproducing it here. The account was published in the "San Francisco Chronicle," upon the authority of Mr. B. B. Redding, then one of the Fish Commissioners of California:

"In Siskiyou County there is a cararansary kept by George Campbell, and known as the Upper Soda Springs Hotel, which is situated on a semicircle of land formed by a bend in the Sacramento River. Wishing to have a supply of fresh trout close at hand, Mr. Campbell had a supply of water conducted through a 
board flume from the river to a natural depression in the ground, thereby creating an excellent fish pond of about half an acre in extent, which he supplied with full-grown trout caught in the river. The supply flume is, for some distance, raised about four feet above the ground. About four hundred feet from the pond, a small rivulet, which is an outlet for irrigating water, flows under the flume, crossing it at right angles and about four feet below it, and empties into the river.

"The fall of water from the end of the flume to the surface of the pond is two feet, the water in the flume flowing with a velocity of three miles an hour. The pond has an outlet, which is sereened to prevent the escape of the trout. Shortly after the pond was established, the discovery was made that numbers of fish were missing from it. Mr. Campbell instituted an investigation, which resulted in discovering that the fish, dissatisfied with their new quarters, had leaped through the waterfall two feet into the flume, and, swimming against the strong current until they reached where the stream crosses under the flume, they had leaped out of the latter to the stream four feet beneath.

" Upon discovering the method of flight adopted by his finny acrobats, Mr. Camplell prevented further escape by placing a sereen at the mouth of the flume. $\mathrm{Up}_{\mathrm{p}}$ to last accounts the rissittisfed fish had discovered no other method of getting into their favorite sacramento. The questions immediately suggest themselves: How could the fish know that a stream flowed under the flume, the sides of which were considerably above the surface of the water, and if they possessed that knowledge, how were they to know that they were immediately over it? Mr. Redding examined the ground carefully along the flume, and could not discover a single instance of a trout having jumped out at any other place."

Mr. Redding subsequently communicated to the "Forest and Stream" the following solution of the matter:

"The attention of Prof. E. D. Cope, the eminent naturalist, having been called to the above facts, he has given me an explanation which seems entirely satisfactory. He tells me that at the base of every scale of the trout, at a point where the scale is united with 
the skin, is a nerve; that all these nerves, from the base of every scale, lead to a large ganglion situated on the center of the forehead of the fish below the eyes; and that nerves from this ganglion communicate to the internal ear. These nerves, at the base of each scale, are formed to receive vibrations in water. Any vibration in water reaching the scales of the fish is thus communicated to the internal ear. If, as was the fact, one of the timbers that supported the flume rested in the running water on the ground, the vibrations of this running water on the ground would be carried by this timber to the flume and to the water in . it, four feet above, and the ear of the fish would separate and take cognizance of the difference in the vibrations, as the human ear in the air distinguishes the difference between the voices of friends."

As many fishes utter sounds, some so loud as to be heard in the air, it is reasonable to suppose that such sounds are heard by other fishes. Most fishes are capable of receiving impressions, through three sets of sense organs, viz., the ears, the skin, and the lateral line organs. Mrr. H. G. Parker, after many experiments, has determined that " the skin is affected by surface wares and by currents; the lateral line organs by slight inaudible movements of the whole mass of water; and the ears by the still more delicate vibrations of water particles, sound."

Among the most intelligent investigations in this direction in recent years have been the experiments just mentioned, of Mr. H. G. Parker, Assistant Professor of Zoology, Harvard University, under the auspices of the U. S. Bureau of Fisheries, at its laboratory at Woods Hole, Mass., during the past year or two. He made many experiments dealing with the cutaneous nerves, the lateral organs and the auditory nerres, on such fishes as were most readily procured, principally with killifishes (Fundulus heteroclitus). These experiments were not confined to fishes in 
aquaria, but to those in open water as well, and in reference to the latter condition he says:

"The sound, therefore, was as unrestricted as that which naturally reaches these fishes. On experimenting with normal fishes, fishes without ears, and those with insensitive skins, results were obtained essentially like those observed in the aquarium, and I therefore concluded that the restriction of the water in the equarium played no essential part in the results obtained from that apparatus. There is, thus, good reason to believe that F'undulus heteroclitus not only hears, but that for it hearing is a normal process."

Mr. Parker means by "fishes without ears, and those with insensitive skins," fishes in which the cutaneous and auditory nerves were severed. His summary of the results of his experiments is as follows:

"1. Normal Fundulus heteroclitus reacts to the sound waves from a tuning fork of 128 vibrations per second by movements of the pectoral fins and by an increase in the respiratory rate. It probably also responds to sound waves by caudal-fin movements and by general locomotor movements.

"2. Individuals in which the eighth (auditory) nerves have been cut do not respond to sound waves from the tuning-fork.

" 3 . The absence of responses to sound waves in individuals with severed eighth nerves is not due to the shock of the operation or to other secondary causes, but to the loss of the ear as a sense organ.

"4. Fundulus heteroclitus therefore possesses the sense of hearing.

" 5 . The ears in this species are also organs of prime importance in equilibration.

"6. Normal Fundulus hetcroclitus swims downward from the top of the water and remains near the bottom when the aquarium in which it is contained is given a slight noiseless motion.

" 7 . Individuals in which the nerves to the lateral-line organs have been cut will swim upward or remain at the top while the aquarium is being gently and noiselessly moved. 
"8. The lateral-line organs in this species are probably stimulated by a slight mass movement of the water against them. They are not stimulated by sound waves such as stimulate the ears.

"9. Individuals in which the nerves to the lateral-line organs have been cut swim downward and thus escape from regions of surface wave action. They also orient perfectly in swimming against a current. Since surface waves and current action stimulate fishes in which the nerves to the lateral-line organs and to the ears have been cut, these motions must stimulate the general cutaneous nerves (touch).

" 10 . The vibrations from a bass-viol string when transmitted to water stimulate the ears and the lateral-line organs of Fundulus. They also stimulate mackerel and menhaden, but not the smooth dogfish, which responds only when in contact with solid portions of an aquarium subjected to vibrations." *

Since Mr. Parker's experiments were made, Dr. J. Zenneck, of the Strassburg Physical Institute, has published in the Archiv fur Gesammte Physiologie, vol. 95, pages $3 \pm 6-356,1903$, an article on the reactions of fish to sounds in the water, and has shown very conclusively that several species of minnows are very sensitive to sound, though he did not determine whether this sensitiveness resided in the skin (touch), or in the ear (hearing), or in both. The sound used was a protected electric bell under the water.

It is conceded that fish can hear sounds or vibrations produced on, or in, the water, but that they can hear sounds produced in the air is doubted by many; but every observant angler can recall instances where this doubt has been refuted. I remember, as a boy, that when swimming below the surface, I could hear the shouting of my com-

* For the full account of Mr. Parker's interesting experiments the reader is referred to U. S. Fish Commission Bulletin for 1902, pages 45 to 64 . Also to the American Naturalist, Vol. xxxvir, No. 435, 1903; and Science, new series, Vol. 17, page 243, 1903. 
panions, though faintly; while the striking of two stones together below the surface was heard more distinctly.

It is well known to some, though doubted by many, that fish can be tamed and taught to come to the surface of the water to be fed, answering promptly to the sounds of the voice, a bell, or a whistle. I have observed instances of this kind, myself, and under such circumstances as rendered it impossible for the fish to see the person producing the sounds mentioned.

In a recent work on "British Fresh-Water Fishes," by Sir Herbert Maxwell, F. R. S., he mentions an incident in support of his belief that fishes can hear sounds produced in the air. One bright October day he was painting on the shore of Loch Kien, in Galloway. He noticed multitudes of small perch near the margin. Presently a shot was fired nearly a mile away. He says:

"The report eame clearly, because of the stillness of the air, but at that distance it could not be called loud; yet the shoal of fry instantly darted into the deeper water. In a little while they began to ereep back towards the shore. Then came another shot; off again went the fry; and so after every shot, repeating the performance for my edification eight or nine times."

I have olserved fish exhibit symptoms of fright or alarm at the report of fire-arms, or other loud noises, and to be scared and dart away at the sound of the human voice, or the barking of a dog, when the fish could not see the originators of the noises.

Birds will remain quietly perched on a tree and seem to take no notice of the sound of the human voice, or of loud noises. It is well known to sportsmen that a covey of ruffed grouse, or mountain grouse, will remain perched one above another in a tree, while the gunner may shoot them, one after the other, by beginning with the lowest bird. 
Horses, cattle or sheep will continue to crop the grass of a pasture, apparently oblivious to all sounds, but will look up at the approach of a man or'a dog. Even wild animals remain motionless at the report of a gun, or other noises, provided the author of the sounds is not seen. And yet, if a fish does not skurry away at similar sounds, it is taken as conclusive evidence that it does not hear them.

It would truly seem, on reflection, that beasts and birds would be more likely to show symptoms of alarm at sounds produced in the medium in which they live, move and have their being, than fishes which inhabit another and denser medium, and consequently feel safe and secure from causes operating in the air.

\section{Senses of Smell, Taste and Touch.}

The olfactory organs of fishes, while being well developed, have no relation whatever with the function of respiration, as in air-breathing animals. Günther says: "It is certain that fishes possess the faculty of perceiving odors, and that various scents attract or repel them." This fact has been patent to olservant anglers since long before the time of honest Izaak Walton.

It is evident that game-fishes, like the black bass, which resort to mid-water and near the surface, depend almost entirely on the sense of sight in pursuit of their food, while bottom-feeding fishes rely on the senses of smell, taste or touch. The latter group of fishes have special nervous filaments ending in what are known to neurologists as "terminal buds," located in the mouth and on the skin of the body; also in the barbels, or "feelers," as in the catfishes, and in the detached fin rays of other fishes. These terminal buds seem to have the property or function of taste, 
being connected with the olfactory bulbs of the brain, and are necessary to such fishes in the procuring and detection of their food.

\section{Do Fishes Sleep.}

As fishes possess no eye-lids, the eyes, consequently, always being open, the absurd question is often asked, "Do fish sleep?" I say absurd, for it certainly seems so to imagine that fishes alone of all the animal creation do not sleep. That they sleep, and sleep every day is not to be doubted. They sleep very lightly, however, and are easily awakened by the slightest jar on the bank, or, as I believe, from sounds in the air of an unusual character. From my observations of fishes in the ponds of fish hatcheries. I think they sleep mostly during the middle hours of the day and night. 


\section{CHAPTER VIII.}

\section{ON STOCKING WATERS WITH BLACK BASS.}

"And it is observed, that in some ponds carps will not breed, especially in cold ponds; but where they will breed, they breed innumerably." - IZAAK WALTON.

TuE black bass is peculiarly adapted, in every respect, for stocking inland waters. There is no fish that will give more abundant and satisfactory returns, and none in which the labor and expense attending its introduction is so slight.

As a food fish, there are very few, if any, more palatable? fresh-water fishes, its flesh being firm, white, and flaky, and when cooked, nutty, tender, and juicy; it has few bones and little offal, and as a pan-fish is unexcelled. Its game qualities are second to none, and it will thrive and multiply in waters where the trouts can not exist.

There are few fish more prolific, while there is none more hardy, healthy, and better able to take care of itself, and none that protects or cares more tenderly for its young; consequently, there is no limit to its production and increase in suitable waters, save from a lack of natural food.

In riew, then, of its many good qualities, there is no fish more worthy of cultivation; none that can be so easily transplanted, and none that is so well adapted to the various waters of our country, for there is no game-fish that has such an extensive original habitat.

Every attempt that has been made, intelligently, to stock suitable waters with the black bass, has been crowned with signal success, which, unfortunately, has not been the case 
with the introduction of other game- and food-fishes. The praiseworthy efforts that have hitherto been made to repopulate streams formerly inhabited by salmon or brook trout, have either totally failed, or the results, in a majority of instances, have not been at all satisfactory; nor does it seem, now, as though these efforts will ever prove successful, owing to causes which I have mentioned elsewhere.

Streams which are necessarily obstructed by dams, even when the most approved fishways are provided, or whose waters are polluted by the refuse of manufactories, can never be successfully stocked with the salmonids; but the black bass seems to thrive fairly well in spite of these and other disadvantages.

From what has been said in regard to their habits, it will readily be seen that there is no necessity for hatching black bass artificially, in the manner practiced with the salmon, trout, or shard. nor would the method be as successful, for reasons well known to fish culturists.

The Salmonida of the eastern United States, with the exception of the grayling, prepare their beds and deposit their spawn late in the fall, or early winter. This being accomplished, all further interest in the procreation of their species, for the time. ceases; the eggs are left to themselves, and such as escape being devoured by their numerous enemies are hatehed in from two to four months, according to species and temperature of water. The young are provider with a yolk-sac, which nourishes them for a period of from twenty-five to forty-five days, varying with the species, when they begin to look for other means of subsistence.

During all this time. from spawning until the absorption of the yolk-sac, from three to six months as the case may 
be, the eggs and young are helplessly exposed to the ravages of predatory fish, reptiles, and birds. Under these circumstances comparatively few fish arrive at maturity, and streams are soon depopulated by seining, unlawful fishing and natural vicissitudes; hence arises the necessity for their artificial cultivation and the re-stocking of such waters.

The eggs of the salmonids are of a separate and nonadhesire character, which admits of their being easily handled and managed for the purposes of artificial reproduction, while those of the black bass are glutinous and adhesive, which renders them very difficult to manipulate for similar purposes.

The black bass being hatched with but a rudimentary or very small umbilical resicle or yolk-sac, needs the fostering care and attention of the parent fish, who teaches it how and where to find its food, and protects it from its enemies in the same way that a hen cares for her brood.

All that is required, then, to stock a stream or pond with black bass, is to procure a small number of the fish, at least a year old, and place them in the waters. If the water is of a suitable character, and possesses a sufficient supply of natural food, the bass will propagate naturally, and rapidly increase in numbers.

The only considerations to be looked after are the character and conditions of the waters to be stocked - sufficient depth and extent of surface being more important than quality of water - and the supply of food contained in them. It is useless to attempt to stock very small and confined ponds of less than three acres in extent; for in such ponds, without communication with running water, the bass will not increase beyond a certain limited number, which will usually be the number of fish originally planted. The supply of natural food in such cases will soon become 
exhausted, and the old fish will prey upon the young, should any be hatched, until a certain average, proportionate to the supply of food, is established and maintained.

In the case of newly formed ponds, they should be well stocked with minnows, crustacea, frogs, etc., a t least a year before the bass are introduced. It is also necessary that there should be in all ponds, holes of not less than twelve feet in depth, to which the bass can retire in rery hot weather, and where they can also hibernate.

In some waters, one species of black bass may prosper better than the other; for instance, in large ponds or shallow lakes, with a sluggish current, muddy bottom, and abounding in fresh-water algæ, the large-mouth bass will thrive better than the small-mouth species. But in streams, and ponds with a good supply of ruming water, either, or both species may be introduced.

The black bass has been sucessfully transported to England. Mr. Silk, fish-culturist to the Marquis of Exeter, has taken over two lots of young small-mouth bass from the Delaware River, the first in $18 \% 8$, and the second in $18 \% 9$. In a letter to the late Frank Buckland, Mr. Silk says:

"In 1879 I went again, and started from America with 1,200 black bass, and on arriving home I had 812, having done better than I did on the previous oceasion. All of the black bass were for the Marquis of Exeter, he having borne all the expense of the experiment. Most of the fish were placed in a lake belonging to his lordship, called Whitewater, near Stamford. Not any of them have been caught yet, but two of them were found dead in a pipe, where they had got jammed. The pipe supplied a filterer, and they had got in and could not get out again. From what I could learn they would be ahout half a pound each in weight, so that they had done very well. The first lot that were put in will be three years old in April, when they are expected to commence breeding." 
In transporting black bass for the purpose of stocking new waters, great foresight, care, and judgment must be used. The size and number of the fish, the distance they are to be carried, and the length of time to be consumed in the journey, must all be taken into consideration. The size and number of the fish will determine the size and number of the containers; thus, while a common wash-tub would be a safe receptacle to transport twenty-five bass, six inches in length, for a long distance, it would not be suffcient for half the number of double the size, for it would require a ressel that would contain at least one and a half times the quantity of water. This is a safe rule to follow, and calculations can be made accordingly.

For small fish, six to eight inches long, the largest size wash-tubs are well adapted, but for larger fish the carrier must be much deeper. If barrels are used they need not be perfectly new, but they should not retain any restige of their former contents, as vinegar, oil, whisky, etc. The best ones would be those that had been used to hold water for a long time. Wooden tanks, constructed for the purpose, will answer, provided they have been soaked in running water a sufficient length of time to take up and remove all the soluble matter of the wood, as tannic acid, etc. Metal tanks, $=$ constructed of galvanized iron, heavy tin, etc., though more expensive, are to be preferred, but they must be rendered perfectly clean before the fish are put into them.

If the number of fish to be carried is large, it is much better to provide a sufficient number of containers than to crowd the fish. Except in railroad cars especially constructed for the purpose, there is no good plan yet devised for aerating water, while in transit, by forcing air into it, for most of it escapes at once as the numerous bubbles that 
appear on the surface testify. The better way is to expose the water to the air in finely divided particles, in the form of spray or small drops, as by forcing or pouring it through a fine rose. I have seen it successfully accomplished by dipping the water out of the container with a common sprinkling-can, or watering-pot, and pouring it back again through the rose, or sprinkler, from a considerable height; this is as simple and effectual a way as any yet devised.

It is a bad plan to change the water frequently, as is often done, for the change in the character and temperature of the water thus produced, affects the fish unfavorably. The best plan, by far, is to aerate the original water. If in warm weather, the temperature of the water should be noted, occasionally, and kept at its original temperature, or a little lower, by the addition of small pieces of ice from time to time.

These instructions are only general, and must be varied to suit particular circumstances. Sometimes, for short distances, double the number of fish may be safely carried, in the space I have designated. Moreover, it is possible to be too attentive, and kill the fish with kindness. If the number of fish to be transported is large enough to justify the experiment, the best and safest plan would be to carry one vessel, with its allotted number, first, and, according to the operator's hest judgment; then. as the experiment proved successful, or not, would depend the transportation of the balance, on the same, or some other plan of proceeding.

A lake belonging to the South Fork Fishing and Hunting Club, of Pittsburg. Pa., was successfully stocked with adult black bass in June, 1881. The transportation of six hundred and sixty bass from Sandusky, Ohio, to the 
lake, ninety miles east of Pittsburg, was carried out very successfully under the direction of Mr. W. A. McIntosh, vice-president of the club.

The fish were placed in fifteen oak casks, three feet high, and three feet in diameter, and five galvanized iron tanks, five feet high, and three feet in diameter. The water was kept at the proper temperature by adding ice occasionally, and aerated by means of a large air-pump and fifty feet of one-inch rubber hose, at one end of which was a series of perforated tin tubes. A large tin tube also ran along above the casks, with a small dependent tube ending in a sprinkler leading to the top of each cask, into which water was poured and entered the casks in a fine spray.

The bass weighed from three-fourths of a pound to two and one-half pounds, areraging one and a half pounds each. The females were heavy with spawn, as the season was backward. They were on the road, from Sandusky to the lake, some thirty hours, with a loss of only sixty fish, or ten per cent. The bass prospered well in the lake, as myriads of young bass, six or eight inches long, were perceived the following year.

They multiplied rapidly for several years, affording fine fishing for the members of the club and their friends. Eventually, however, the dam inclosing the lake gave way under the pressure of a great flood, and the appalling disaster at Johnstown was the result.

Not only in our own country have new waters been successfully stocked with both species of black bass, but they have been transplanted to England, as mentioned, also to Scotland, Germany and the Netherlands.

A later notice of those taken to England is as follows:

"Of twelve hundred black bass brought from the United States by Mr. W. T. Silk, one hundred and forty were placed in the 
river Nene. They were from four to seven inches in length. The river has a number of small backwaters, with swift currents and gravelly bottoms, and also deep, quiet holes. Fishing will be prohibited for some years, until the fish are well established. I think the Nene and the Welland are the only rivers in England where the bass have been put; but they are in several lakes."(London Fishing Gazette, December 1, 1883.)

I assisted Herr Von dem Borne with such information as subsequently enabled him to successfully cultivate the Wack bass in Germany. The following is the account of his first installment.

"Of the seven large-mouth, and forty-five small-mouth bass which Mr. Eckardt, Jr., brought from America in February, 18s3, the greater number died, probably in consequence of the long journey, so that this spring there remained only three of the former and ten of the latter, which I placed in two ponds, supplied with gravel beds for spawning."-(Max Ton dem Borne, Circular To. 4, 1884, German Fishery Association, Berlin, June, 1884.)

The ponds of Ton dem Borne, alluded to above, are located at Berneuchen, Germany. On June 15, 18st, he wrote:

"To-day I had the satisfaction of finding that the three large fish had spawned, and the pond actually swarms with fry. I have caught with a small net more than two thousand, and have put them into another pond which is free from other fish. I have no doubt that next spring the small-mouth bass will spawn, and that the experiment will be successful." - Bull. U. S. Fish. Com., Iv, 1884, 219.)

In June, 1885, he said:

"My thirteen black hass have spawned. I have eaught 11,800 of the fry, and placed them in ponds that have no other fish." 


\section{In August, 1885, he wrote:}

"I am pleased to say that the fish multiplied abundantly. I had 1,200 in the fall of 1884 , and have caught more than 22,000 fry this season."

Count Von dem Porne raised more black bass, of both species, than he could take care of, and shipped them to other parts of Europe. In 18s6, he published a small treatise: "Der Schwartzbarsch und der Forrellenbarsch" (The Black Bass and the Trout Bas, ), and a larger edition in 1888. Until he died he wals very enthusiastic in regard to the black bass as a game-fish and food-fish.

In Narch, 185:), Mr. Eugene G. Blackford, of New Iork, sent five young black bass to the Zoological Garden at Amsterdam, where they arrived in exeellent condition. In December, 1885, the "Journal of the Society for the Promotion of the Fresh-water Fisheries in the Netherlands," says :

"The Amsterdam Aquarium at present possesses four fine specimens of black bass, which grow well, and will, in all probability, reach sexual maturity."

In April, 1882, Mrr. Geo. Shepard Page took a small lot of black bass, comprising both species, on the steamer Spain, from New York to Liverpool. Six of the fish were supplied by Mr. Eugene G. Blackford, of New York, and twelve young and five adult fish were supplied by Professor Spencer F. Baird, U. S. Fish Commissioner. Two of the adult bass died before reaching Liverpool. The balance were safely transported to Golspie, Sutherland, in Scotland, and placed in a loch belonging to the Duke of Sutherland.

I wish to add a word in this connection to a paper of 
mine read before the American Fisheries Society, in reference to objections urged against the introduction of black bass into eastern waters, upon the theory that the presence of the "voracious" bass would militate against the increase of shad, trout or salmon. The objections are not valid, or founded on fact, for the black bass prefers a diet of crawfish, when he can get it, varying it with minnows, insects, larra, and frogs, and in eastern waters he would not object to young eels. Pike, pickerel, pike-perch, and gar-fish, are almost entirely piscirorous in their habits, which might be expected from the character of their teeth, which are separate, sharp and conical, and their sins have no doulbt been charged io the black bass. But, while the bass will take in a young shad or salmon if it comes his way when hungry, he will not make them special objects of pursuit, like the canine-teethed fishes above named.

The failure to restock such streams, if any such failure exists, must be attributed to other causes than the introduction of the black bass, prominent among which is the unrelenting pursuit of the young fry by the predatory fishes mentioned. They are only exceeded in their destructiveness by the genus Homo, with his miles of gill-net's at the mouths of the streams. to prevent the return of the shad or salmon during the breeding season; and should a few run the gauntlet and succeed in depositing their spawn in the upper reaches of the rivers, the eels, bullheads and suckers take good care of it.

In western waters where the black bass exists with the usual varieties of fishes, there is no perceptible decrease in the numbers of either. If any species suffers it is always the black bass on account of over-fishing, spearing, etc. I know of isolated lakes in Wisconsin where the black bass has co-existed with the eisco (one of the salmon family), 
longer than the memory of man runneth to the contrary, without a decrease of the latter fish. If then the bass can not "get away with" the cisco in confined waters, how can he "clean out" the shad or salmon in large flowing streams? Horeover, I know of a small stream in Wisconsin that abounded in black bass and crawfish, into which brook-trout were introduced to the discomfiture of the former fish, for the trout increased while the numbers of the bass grew smaller by degrees and beautifully less. I also know of lakes in Canada that have always been inhabited by both brook trout and large-mouth black bass, with no detriment to the former fish. And, furthermore, the black bass will not eat the spawn of his mate, nor that of his fellows' mates. His natural food is the crawfish and the minnow; he prefers them, and they are easily procured. On them he will wax and grow fat, increase and multiply. The man who alleges that he depopulates the streams of valuable food fishes, or asserts that he "kills for the love of it," has never looked into the mouth of the bass with his eyes open, for its teeth on both jaws are brush-like, incapable of wounding - forming merely a pair of broad, rough forceps for holding its prey securely.

If, then, there are waters in which the brook-trout or the rainbow-trout will not thrive, there need be no hesitation to aid in the further distribution of the black bass by introducing that desirable species. It is easily done, and success is already assured. It is only necessary to look to the Potomac, the Susquehanna, the Delaware and many other streams for evidence of its rapid increase in new waters. 



\section{PART II.}

\section{TOOLS, TACKLE AND IMPLEMENTS.}




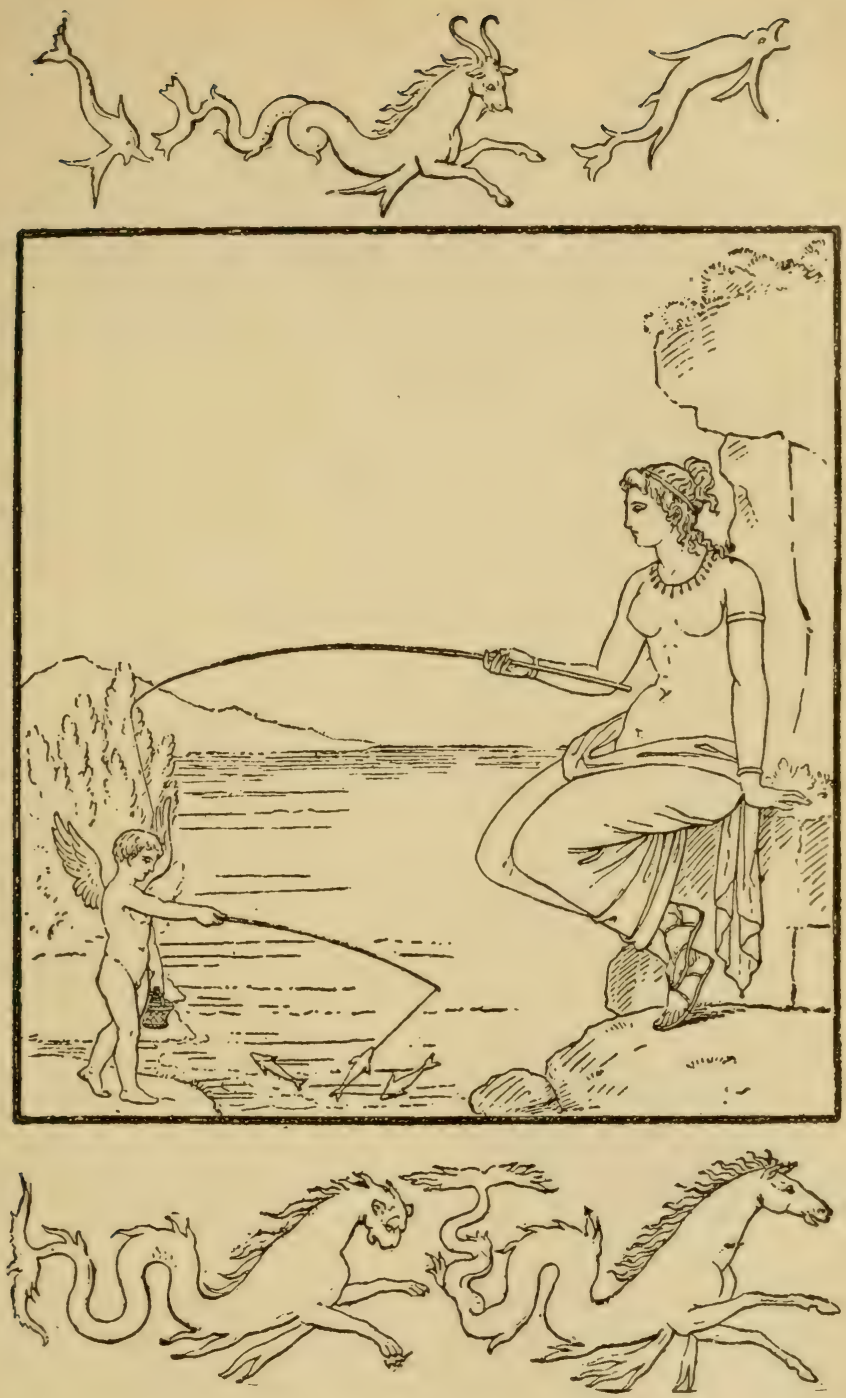

VENUS AND CUPID FISHING.

From a copy of a wall painting at Pompeii in possession of R. B. Marston, Esq., Editor of the Fishing Gazette, London, England. 



\section{CHAPTER IX.}

\section{FISHING RODS.}

"And now, scholar! I think it will be time to repair to our angle-rods."- IzAaK WALTON.

THE first and most important article in the angler's outfit is the rod; it takes precedence of every other tool or implement in his armamentarium. A thoroughly good and well-balanced rod is the angler's especial joy and pride. A true and tried rod of graceful proportions and known excellence, which has been the faithful companion on many a jaunt by mountain stream, brawling river, or quiet lake, and has taken its part, and shared the victory in many a struggle with the game beauties of the waters, at last comes to be looked upon as a tried and trusty friend, in which the angler reposes the utmost confidence and reliance, and which he regards with a love and affection that he bestows upon no other inanimate object.

I loubt if rifle, shot-gun, or fowling-piece ever becomes so clear and near to the sportsman as the rod to the angler, for the rod really becomes a part of himself, as it were, through which he feels every motion of the fish when hooked, and which, being in a measure under the control of his will, and responsive to the slightest motion of his wrist, seems to be imbued with an intelligence almost lifelike.

The essential qualities of a fishing rod, are balance, strength, clasticity, pliancy, and lightness, and in its construction such a wood, or combination of woods, must be used as will best subserve these conditions. The natural cane, or reed pole, when it is of good and true taper, is 
the primitive model for a fishing rod, but it is not adapted to all kinds of angling, being too long for one mode, too stiff for another, and not well balanced for a third.

The nearest approach to a perfect rod, in theory, and composed entirely and alone of any one variety of wood is a red cedar rod, made entirely of one piece from butt to tip. It combines all of the essential qualities of a fishing rod, and can be made suitable for any method of angling long or short, stiff or pliant, and withal, is extremely light; but in practice it is not tough or strong enough for the ordinary angler. And so each and every kind of wood has some objections when used, alone, in the construction of a rod; most kinds of wood being too heary, when other qualities are all right.

The next best thing is to use a combination of woods, and this plan has been found by experience to be the best. Another plan is to alter the natural conditions of a wood by mechanical skill. as in the split-bamboo rod, by which the original natural good qualities are not only preserved, lint improved upon by the skill of the workman.

\section{Matefial for Rods.}

In order to get proper and desired action of combined woods, and for convenience, portability, and ease of being repaired, rods are very properly made in several pieces, or joints. The fewer pieces used, however, the better will be the action of the rod, and. in fact, two, or at most, three pieces, are sufficient for all kinds of rods except salmon rods, which are of a necessity the longest rods made.

In the selection of woods for a rod, such kinds must be used as possess the principal attributes of a fishing rod, which are toughness and elasticity; and when these qualities are combined with lightness, there is nothing more to 
be desired, for proper modeling will insure perfect balance and pliancy.

Many kinds of native and foreign woods have been tried and experimented with to produce a rod perfect in action, such as cane, ash, hickory, maple, basswood, ironwood, hornbeam, cedar, barberry, bamboo, memel, lancewood, mahoe, greenheart, bethabara, noib, snakewood, dagama, service-berry, etc. For black bass rods, howerer, both for fly and bait, it has been found that split-bamboo, ash, lancewood, bethabara, and greenheart are the most suitable woods.

Ast.- For butts of rods there is no wood so suitable as good, close-grained, second-growth white ash. It is straight-grained, light, springy, and strong, and in some kinds of rods it is also available for second pieces or joints, having a springy "snap" possessed by no other wood.

LANCEWOOD.- For second pieces and tips, lancewood, when of good quality, stands pre-eminent, being closegrained, tough, and extremely elastic, with sufficient resiliency for small joints. It is used for tops, or tips, more universally than any other wood, on account of its superiority over all other varieties for this purpose. It is rather heavy for butts, though often used for this nurpose, some fly-rods being constructed entirely of this fine wood, making very durable and beautiful rods, with a good action, but still rather heavy for most anglers.

Greenheart is next to lancewood for tips, and for second joints is preferred by many; it is somewhat heary, and quite tough and springy. Many rods are made entirely of this wood, and are excellent, too, by the way, but rather heavy for the admirers of light rods. It certainly forms a handsome rod, when nicely polished, and is capable of good and hard service. In England it is a farorite wood 
for fly-rods, where, as a rule, much heavier rods are used than in our own country.

Betrabar..-This wood was, I believe, introduced several years ago by A. B. Shipley \& Son, of Philadelphia, who made a specialty of rods of this handsome material. It is rery dark in color, resembling, somewhat, blackwalnut. It is rery hard and close-grained, almost like bone in density, though it is rather heary, except for second pieces and tips. Few woods can equal it for strength, tonghness, and resiliency. It is susceptible of a beautiful polish, and I know of no other wood that makes so handsome a rod in its natural color.

Cane, or Reien.- Native and foreign cane poles are much used for fishing rods, especially in certain kinds of angling where no reel is required, and for such service answer a good purpose. The native cancs are the lightest, though not so strong and durable as the Chinese or Japanese canes.

Calcetta Banboo.-The East Indian, or, as it is gencrally termerl, the Calcutta bamboo, is the best of all material for the ronstruction of a perfect rod when carefully made by a skillful and master workman. In its natural state it possesses many of the desired qualities for certain modes of angling, but for methods that require a shorter and lighter, or more pliant rod, these additional features can be secured by altering the original conditions of the cane, by sawing the outer, or cortical siliceous, layer into triangular strips and accurately fitting and gluing them together; thus reducing the caliber, and, at the same time, preserving and enhancing all the essential and desirable qualities in a more compact form.

There are two kinds of Calcutta bamboo, known to the trade as "male" and "female" canes. The former is 
nearly solid, hard, and very tough, with large and protuberant knots or joints, where, when growing, are attached the leaves and tendril-like branches, which are so tough as to render it necessary to burn them off; this, and the application of red-hot iron to straighten them, gives to these canes the peculiar clouded and burnt appearance which adds so much to the beauty of the split-bamboo rod. The female cane is hollow through its entire length, except just at the joints or bulges, which are not so prominent as in the male cane. The male cane is the best to use in its natural state, but for split-bamboo rods the selected female cane is to be preferred as it makes the most perfect rod.

There has been very marked improvement in the manufacture of fishing rods during the past twenty years. More attention has been paid to the demands of the angler by the manufacturers, who have, consequently, exercised greater skill and intelligence in supplying tools better adapted to his needs and requirements. This has resulted in shorter, lighter, and better-balanced rods, and of much better material and workmanship than was formerly accorded to this branch of the arts.

It is a source of great pleasure and satisfaction to the angler of the present day to note the march of improvement in the manufacture of fine fishing tackle, and to observe the commendable enterprise manifested by the manufacturers in producing light, elegant, and suitable implements of the craft. Indeed, the skill, study, ingenuity and good taste employed in this industry is scarcely excelled in any other; all of which is highly gratifying, for it would seem to imply that the love and practice of angling has taken deep root, and that fine fishing and scientific angling are in a healthy state of growth and development. 
The first radical departure in the manufacture of fishing rods was the introduction of the "Henshall rod" for black bass bait-fishing, more than a quarter of a. century ago. After its superiority to old style long and heary rods was demonstrated, it became an easy matter to apply the same principles to all other rods.

Perhaps it would be too egotistic to say that this shortening and lightening of ro?'s in general was induced, altogether, by the introduction of the Henshall black bass rod, but I am assured by some of the most candid rod manufacturers, and by many anglers, that this result is in a great measure to be attributed directly to the superior excellence of this short, light, and elegant rod, and to the fact that it subserves all the purposes. and promotes the pleasures of black bass angling in a much greater degree than the old-fashioned long and heavy rods. I am very much gratified to think that this may be the case.

One of the largest manufacturers of fishing rods in the world has this to say:

"More than twenty years ago Dr. James A. Henshall, an authority on black bass, and at present an attache of the United States Department of Fisheries, declared that the black bass would eventually become the leading game fish of America; also that the invention of the necessary tackle would place such fishing in the very forefront of angling effort. At that time the statement impressed most sportsmen as a rery rash prediction; for no indications of such an outcome were visible to them. Thus, as so frequently happens, the prophecy was looked upon as the mere fancy of an enthusiast.

But time, that demonstrator of all propositions, evidently enlisted on the side of Dr. Henshall, so that to-day we marvel at the accuracy of the forecast. At that time, tackle designed especially for black bass was scarcely known, whereas to-day it forms a large portion of the entire amount made in this country. Naturally the one who foresaw the tide of events, and who was 
an authority on such fish, would be best equipped to furnish specifications for the most desirable rods."

\section{Split-Bamboo Rods.}

A first-class split-bamboo rod is the ultima thute of rod making. In its construction great care and skill are exercised. The material is carefuily selected by an expert, as the several sections for a joint must be perfect and of the same weight and bend, in order to secure homogeneity and perfect action. This requires technical skill and intelligence of a high order. But the cheap and shoddy kind sold in department stores is made of refuse cane by unskilled labor, and is sold at a small advance on the cost of production. A hard wood rod at thrice the price is infinitely better.

I consider the split-bamboo rod to be the greatest invention ever made pertaining to the art of angling, equaling the invention of the breech-loading rifle and shot-gun for field sports.

The history of the "split-bamboo," "section-bamboo," or, as it is sometimes called, the "rent and glued hamboo" rod, although of comparatively recent origin, dating back only some sixty years, is somewhat obscure. Several persons have laid claim to the invention, though with what justice it has, heretofore, never been clearly determined.

There is, perhaps, no important mechanical invention that has, in its inception and principle, sprung entirely and spontaneously from the brain of any single individual; and this will apply to the split-bamboo rod as well, for though purely an American invention, as now constructed, the idea, or principle, is really of English origin. Rods formed of several pieces of hard wood, that is, from two to three longitudinal sections mitred and glued together, were 
made in England many years ago; and Aldred, of London, made rod tips, or, as they are called in England, "tops," of split-bamboo, before the split-bamboo rod, proper, was made in this country. Aldred's tops, however, were necessarily a failure from the faulty method of their construction. He made them of many short pieces sawn from between the knots, or leaf-ridges, of the male cane, and spliced, to form continuous lengths. So much for the original idea.

It is not my province, nor desire, to detract one iota from the credit or just due of any one in this matter, but rather to render unto Ciesar those things that belong to Casar. In the following pages I will present only such rvidence as is entirely trustworthy, having been obtained from authentic sourees, and put it on record here as reliaWe lata in regard to the early history of the American split-hamboo rod; and in so doing I hope to do justice to an obscure, but worthy brother of the angle.

The following amplified account of the invention of the split-bambon rod I contributed to the "Outing" magazine for May, 1902. As a matter of recori I reproduce it here:

\section{Origin of the Split-Bamiboo Rod.}

In an artmirable and comprehensive article on "Salmon Fishing" in "Scribner's Magazine" for October, 18\%6, Dr. A. G. Wilkinson, of the Patent Office, Washington, I. C., gives, so far as I know, the first history of the splitbamboo rod and its method of construction. Incidentally he says :

"Twenty-five rears ago (1851) a London firm made splitbamboo rods, putting the enamel inside. * * * Mr. Phillippe, living at Easton, Pa., conceived the idea, in 1866, of putting the enamel upon the outside, where it would do the most good. Next, 
Mr. Green and Mr. Murphy put their heads together, and made rods of this sort of four strands, and finally the old and wellknown firm of A. Clerk \& Co., New York, introduced into the market the Leonard rod of six and twelve strands, and have since been supplying Europeans with all they get of this article."

In 1881, in my " Book of the Black Bass," I gave a brief history of the origin of the split-bamboo rod as made in the Tnited States. giving credit for the invention to Samuel

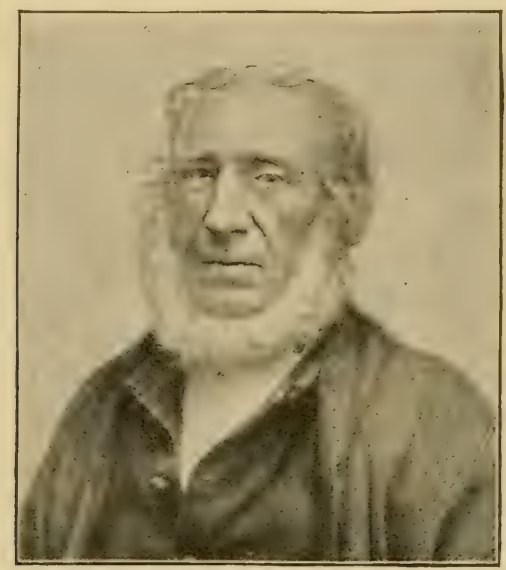

Mr. Samuel Phillippe.

Phillippe, of Easton, P'i., and the date of his first rods as early as 1848 . The proofs that I produced were complete and authentic enough to establish the claim for Phillippe as the inventor of the split-bamboo rod in America, and certainly as the first in the world to make a foursection rod. Those made in England about that time, and exhibited at the first World's Fair at the Crystal Palace in London, in 1851, were all three-section rods; that is, 
three triangular strips, or sections, either with the enamel inside or outside. These were known as "rent and gluedup " bamboo rods, and were shown by severa! makers. *

Mr. William Mitchell, of New York, an excellent and well-known rod maker, in an article on the split-bamboo rod in the "American Angler," says:

"Mr. Wilkinson gives the year 1866 as the one in which Mr. Phillippe, a gunmaker of Easton, Pa., made a glued-up splitbamboo rod in three sections, or parts of one. He was followed by Mr. Green and Mr. Murphy.

“Dr. Henshall, in his 'Book of the Black Bass,' gives the date of the first split-bamboo rod made in this country, by Samuel Phillippe, as about 1848; but all dates are from memory, and I believe the date given by Mr. Wilkinson is the nearer approach to the eorrect one. Mr. Philippe never made a complete rod of splitbamboo, only a tip and joint to a three-piece rod, the butt of ash, and the joint and tip made in three sections.

"Mr. Murphy, of Newark, N. J., in an article by Mr. B. Phillips, on the origin of the split-hamboo, published in the New York "Times," gives the date as 1848, when Mr. Phillippe used the natural bamboo, and subsequently made a joint of bamboo."

Satisfierl that there was some crror or mistake concerning the date, 1866, as given by I)r. Wilkinson, I afterward wrote to him on this point, when he replied as follows:

"You are certainly all right on the split-bamboo question. Mitchell gives the date of Murphy's rods as 1863, and Murphy concedes priority to Phillippe, and the latter's date is 1846. At the time of writing I could not fix Murphy's exact date. I am now

*[As late as 1870, in Bohn's edition of Walton's Complete Angler, edited by Jerie. Mr. Bohn says in a footnote: "The splitcane or glued-up rod is difficult to make well, and very expensive; it is made of three pieces of split cane (which some say should have the bark inside, some outside), and is said to have the advantage of not warping through wet."] 
clearly of the opinion that Phillippe's son carelessly wrote 1866 in place of 1846 , and in fact I remember perfectly well that his figures were pretty difficult to decipher."

In order to confirm and substantiate the claim I made for Phillippe, I subsequently corresponded with several of his old fishing companions and friends, citizens of Easton, Pa., with the result that I am now able to fix the date of his first rods as early as 1845 .

At the World's Columbian Exposition, at Chicago, in 1893, I exhibited in my department an oil portrait of Samnel Phillippe, together with several of his rods, one of which is now in my possession. It is one of his first rods, and is still in as good practical condition as when first made. It is a trout fly rod, 11 feet $t$ inches in length, and weighs exactly 8 ounces. It is a perfectly proportioned rod, as the following diameters show: Greatest swell of butt, 1 inch; inside diameter of first ferrule, $5-16$ ths of an inch; of second ferrule, 3-16ths of an inch; of extreme tip, 3-32ds of an inch. Length of reel seat. $3 \frac{1}{2}$ inches; diameter, 11-16ths of an inch. Length of butt handle, from reel seat to end, 10 inches, including the iron thimble at end. If the end of butt was shortened, as in modern rods, the weight would be reduced at least $1 \frac{1}{2}$ ounces. It is marle of four sections of bamboo, except. the butt, which is of stained ash, and is neatly wrapped with black silk on the bamboo joints. The ferrules and reel bands are brass.

The other rods exhibited were of four and six sections or strips throughout, including butt. One of the latter was a very finely finished and handsome rod with solid silver mountings, neatly engraved; it was accompanied by a reel of mother of pearl, the only one I have ever seen. This last was doubtless one of his later rods. 
My opinion now is that Phillippe was really the first maker, and consequently the inventor of the split-bamboo rod, and made his first rod before they were made in England. I do not beliere that the three-section rent and glued-up bamboo rod was made in London previous to 1845, though rods of three sections of hickory and other hard woods were, perhaps, made as early or earlier.

I do not think it possible that Phillippe, in a small interior town in Pennsylvania, ever heard of an English split-bamboo rod before his invention; for even Mr. Mritchell, an old and experienced rod maker of New York, says in the article referred to:

"The first split-bamboo rod I ever saw or heard of was made by Wm. Blacker, 5t Dean street. Soho. London, and to order, for James Stevens, an old and well-known angler, of IJoboken, N. J. This was in 1852, and it was given to me for repairs and alterations in that year."

The late Profeswor Alfred M. Marer, entitor of the Century Company's "Sport With Rod and ('mun," in a footnote to Dr. Wilkinson's article, says in reference to this rod:

"I have seen a split-lambon rod made aceording to the sugges. tions of that distinguished angler, the late James Sterens, of Hoboken, by Blacker, of London. This rod is of three sections, with the enamel on the outside, and was made in 1852, while AIr. Stevens was in London. This date has been accurately determined for me by his son, Mr. Frank Stevens."

Notwithstanding the great number of British books on angling published during a century, there is no mention of

* Dr. A. G. Wilkinson was the first to suggest to the editor of "Seribner's Magazine," Dr. Holland, to publish a series of articles on sports with gun and rod, of which his was the first. 
the rent and glued-up cane rod previous to $184 \%$ In this year "Ephemera" (Edward Fitzgibbon) published his " Ifand-book of Angling," in which he gives a description of the method of Mr. Little, a London rod maker, in the construction of a salmon rod composed of an ash butt, with the other joints of three-section split and glued-up bamboo cane.

During the Chicago World's Fair a daughter of Samuel Phillippe called on me and gave me a rery interesting account of her father. Among other things she stated that after her father's death Joseph Jefferson, the actor, called at their house and purchased one of her father's rods.

Mrr. Solon C. Phillippe, of Easton. Pa.. a son of Samuel Phillippe, furnished me with the following notes concerning his father:

"Samuel Phillippe was born August 9, 1801, in Reading, Pa., and died in Easton, Pa., May 2.5, 1877. He went to Easton when about sixteen years old, where he learned the trade of gunsmith with Mr. Peter Young. He was a skilled workman in wood or metal. He made violins and fishing rods in addition to his regular work as a gunsmith. He received a silver medal for one of his violins from the Franklin Institute Fair, at Philadelphia. He made the first "Kinsey" fishing hooks from patterns furnished ly Phineus Kinsey, of Easton. Pa. He was a good trout fisher, and fished at times in company with Thad. Norris, of Philadelphia, and Judge Jas. Madison Porter, Colonel T. R. Sitgreares, Wm. Green, Phineus Kinsey, John and Abraham DeHart, Sheriff Heckman, and others of Easton.

"He visited a number of places with Mr. Thad. Norris, when the latter was seeking a location for a trout hatchery, and which was finally located near Bloomsburg, N. J. Mr. Norris often saw Phillippe at work on split-bamboo rods in his shop. Charles F. Murphy, himself a noted rod maker, of Newark. N. J., also visited Phillippe to learn something of his method of making split-bamboo rods. 
"In his first experiments Phillippe made tips and second joints of two, and then three sections of split-bamboo, enamel outside, with butts of solid cane or ash. But these rods would not east the fly true. He then made the joints of four sections, and found that they would cast perfectly in any direction. He then made complete rods of four sections, including the butt, and iater of six sections or strips; the enamel was always on the outside. These rods were for his own use, but afterward he made some for his friends, one of the first being for Colonel T. R. Sitgreaves, with ash butt and joints of four-section split-bamboo.

"His books show that the first split-bamboo rod sold was in 1848. This was a four-section rod in three pieces, all split-bamboe, including the butt. His first rods were made certainly as early as 1845. Solon Phillippe learned rod making, in addition to the trade of gunsmith, from his father. In 1859 Solon made a complete rod of six sections; the handpiece, 18 inches long, was made of twelve scetions of hard wood. In 1876 he made a threepiece rod, with handpiece of red-wood, and balance of rod of eight sections or strips, four of split-bamboo, and four of snakewood, alternating."

Following are cxtracts from lotters relating to this subject from some of my correspondents, as evidence to corrobolate my opinion that Simuel l'hillippe was the first maker of the split-bamboo rod:

From Mr. Geo. W. Stout, of Easton, Pa.:

"I came to this town in 1851. I made my first split-bambon rod in 1860, and got my idea from Phillippe's rods. I was an amateur only, and never made more than a dozen in all. *** ExSheriff Thos. Ifeckman, now in his eighty-sixth year, was a lifelong acquaintance of Phillippe, and often went fishing with him. $\mathrm{He}$ is well preserved, with an excellent memory, and is good authority. IIe says he knows that Samuel Phillippe made splitbamboo rods in 1846. Edward Innes, a man of repute, aged about sixty-seven, remembers seeing him making one of these rods in 1847. You may rely implicitly on the evidence of Heckman and Innes, who both fished with Sam before, and many years after, 1846. Innes was much at Sam's shop before 1847, and fixes the 
date by its being just before he removed to Philadelphia, where he resided several years."

From Mr. Thos. Heckman, ex-Sheriff of Easton, Pa.:

"I knew Sam Phillippe a great many years, some sixty or seventy. I have fished with him many times, sometimes for a week's camping in the mountains of Monroe County. He was the first man in this part of the country to build a split-bamboo rod. He made two for me, one of which is still in good condition. To my best recollection he built his first rod about 1846; he made his own ferrules, rings, and keepers."

\section{From Abbey \& Imbrie, of New York City:}

"Your account of the origin of the split-bamboo rod is perfectly" correct. Our Mr. Abbey, the writer, was the active member of Andrew Clerk \& Co. at the time of the origination, by Mr. Phillippe, of the split-hamboo rod, and is, therefore, well acquainted with its history down to the present time."

\section{From Mr. Chas. F. Murphy, of Newark, N. J.:}

"Mr. Chas. Luke, of this city, formerly of Easton, Pa., used to fish and hunt with Mr. Phillippe, and frequented his workshop, where he saw him use split-bamboo for fly rods certainly as far hack as 1848. Luke moved from Easton to Newark in 1850. I am very certain you can give Phillippe credit for the discovery of split-bamboo for fly rods without fear of being contradicted. While making rods for Andrew Clerk \& Co., Mr. Abbey, of that firm, showed Mrr. Green and myself a rod made by Mr. Phillippe. the top and second joint made of split-bamboo. with butt joint made from white ash. I made the first split-bamboo salmon rod, also the first black bass rod of split-bamboo."

From Dr. W. W. Bowlby, of New York City:

"My earliest recollection of the split-bamboo rod dates back to about the year 1852. At that time I lived in New Jersey, near 
Easton, Pa., and fished in the same waters in New Jersey and Pennsylvania with an old gunsmith of Easton, known among us as 'Old Sam Phillippe.' It was about the year above named that I saw a split-bamboo rod in his possession, and he informed me at the time that he was the originator of the idea; and to him, I earnestly believe, belongs the credit of having first conceived the idea of constructing a rod from such material."

While certain parties were compelled to concede the priority of Phillippe in this matter, they sought to detract somewhat from his laurels by pronouncing his rods crude affairs, with the added remark that they were not "complete," having white ash butts. Now, judging from the rod in my possession. old Sam Phillippe knew just what a trout fly rod should be in its action, both in casting a $\mathrm{fly}$

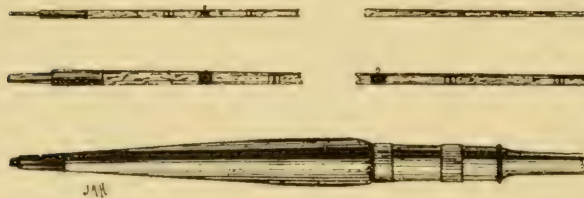

Philippe split-bamboo rod in possession of the author.

and in playing a trout: and it is on these qualities of a rod that its merits should be julged, rather than on the style of its comstruction or fine appearance. Of course, it is better. and desirable. to have heauty of form combined with excellence of action whenerer this is possible; but I have seen hundreds of split-bamboo rods that, while they were all that could be desired as to style and appearance, were sadly lacking as to the purposes and uses for which they were constructed.

The ash butt of my Phillippe rod gives just the right amount of backloone, and the bamboo joints just the requi- 
site pliancy and resiliency needed in a fly rod. Its joints are just as straight and intact as when first made. It is as honest and reliable, and, I might say, as perfect a rod, so far as its uses and action are concerned, as some of my modern rods, "complete" though they may be.

But old Sam Phillippe also made rods entirely of splitbamboo, and of six sections as well, afterward, and, as I now believe, before any other maker attempted the construction of a split-bamboo rod. And that he improved on his earlier efforts those who saw the silver-mounted sixsection rod in my exhibit at the Chicago World's Fair can bear witness.

The first split-bamboo rods for the trade were made by Mr. Charles F. Murphy, of Newark, who made the first split-luamboo salmon-rod in 1865, which Dr. Andrew Clerk took to Scotland, where it proved a success. Subsequently, Genio C. Scott took the same rod to the St. Lawrence, and, on his return, published an interesting account of his trip and the use of the rod, in Wilkes" "Spirit of the Times," in the same year. The first split-bamboo black bass rod was made by Mr. Murphy, in 1866 .

To Andrew Clerk \& Co., and their successors, Abbey \& Imbrie, belong the credit and honor of bringing this rod to its present state of perfection and prominence. They were the first patrons of Phillippe, Murphy, and Leonard, and gave them every assistance and encouragement.

The best form of the split-bamboo rod, in my opinion, as proved by actual service, is the round, six-section rod. Many experiments have been made to improve upon this method. The hexagonal rod is claimed to be preferable to the round rod, inasmuch as there is no cutting away of 
the surface enamel or outside siliceous coating, at the angles, as in the formation of the round rod, and is therefore a stronger rod.

While this looks plausible enough it has no foundation in fact. The hexagonal rod is not a true six-sided figure, but rather a round figure with six angles; for the face of each section is of course slightly rounded, or convex, as it originally existed in the cane, and the extremely small amount of outside surface that is taken off at the angles to make the rod round does not amount to much, or weaken the rod a particle. In my opinion a round rod will cast truer in every direction.

Another plan has been adrocated, to reverse the process in sawing the strips, and place the enamel or outside coating at the interior of the rod. And still another, and somewhat hetter plan, by the way, has been proposed, more especially for tips, as follows:

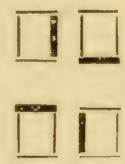

The shaded sides of the sections represent the outer coating. The sections are to be pressed together, and glued in the position in which they are drawn in the figure, which brings the enamel of each strip partly inside and partly outside; the piece is then worked down to a round form, having the center of enamel, and the circumference of alternate strips of inside and a small portion of the siliceous or outside layer.

Then these rods have been made of eight and nine strips; but there is no real merit in any of these last-mentioned 
plans, and the six-section, outside enamel, hexagonal or round, is the only common-sense, practical plan.

A first-class split-bamboo rod is strong enough for all the emergencies of bait- or fly-fishing if properly handled, but in England a steel wire center is added by one maker, and spiral wire ribbing by another, though the latter is for whole cane rods. In this country, natural bamboo rods have been closely wound with linen thread to add stiffness and strength. The best plan to meet these requirements is that patented by Mrr. J. MI. Kenyon, of Toledo, Ohio, and consists in closely winding with rery fine silk from butt to tip, and using several coats of transparent varnish. The rod when finished is a beautiful object, requiring the aid of a magnifying glass to see the silk wrapping. It is callect the "silkien" rod, and is also made by the T. H. Chubb Rod Co., Post Mills, Tt. The first rod made on this principle that I ever saw was alluded to in the first edition of this book. It was spirally wrapped with fine strips of rattan. In appearance it was a beauty, but in practice a complete failure.

\section{Black Bass Batt Rods.}

The black bass and its mode of capture, prior to 1870 , was altogether too much neglected, if not entirely ignored, by most writers of that period upon the gentle art, either from a lack of interest, or a want of proper information upon the subject. Some works that were held in the highest esteem contained the least information upon black bass angling, and even that little was unreliable and unsatisfactory. As a rule, our old angling authors damned the black bass with faint praise, and gave but the most primitive methods for its capture. 
IIost writers of that time deroted their attention exciusively to the salmon and brook trout among the freshwater game-fishes, or to the striped bass, bluefish and weakfish, among the salt-water species. While acknowledging the game qualities and fine sport afforded the angler by these different species, and which acknowledgment is founded upon ample personal experience with them all, I regard the black bass as one of our gamest fishes; and an experience of more than forty years has convinced me that the sport afforded lyy it is not surpassed by the pursuit of any other member of the finny tribe.

Thirty years ago a preson entering a tackle shop in a western town and inquiring for black bass tackle, would be presenterl with a rod from twelve to sixteen feet long, weighing from one to two pounds, a large brass reel, with a handle like a coffee-mill crank, a line more suitable for a chalk line, and a large ungainly hook with a side bendand all this formidable array of clumsy apparatus to do hattle with such a thoroughlired and noble foe as the black hass! Combination rods, general rods, perch rods, cheap striperl-bass tackle, et hoc genus omne, had been, as a rule, manufactured for the western market, and sold for black bass fishing.

This wat the more surprising as the black bass inhabited so many of the waters of the Union. from New England to Florida, and from Maryland to Missouri. He was, moreover, the acknowledged peer of the brook trout for gameness by those who knew him best, and it was "a consummation deroutly to be wished" that as much skill should be displayed in his capture, and as elegant and as suitable tackle employed for the purpose as in the case of his speckled rival.

Those enthusiastic and observant anglers who learnerl 
from experience that there was a want not supplied in black bass rods, as offered by the trade, and who possessed sufficient mechanical skill, constructed their own rods and fished in their own way; and as these worthy souls were generally regarded as authority in their respective localities on the subject of black bass fishing, and not without reason, their particular style of rod was adopted in their particular locality as the "perfect bass rod." This will account for the marked difference of opinion upon this subject in different sections of the country, for each such rod was made in accordance with the style of fishing, and the character of the waters to be fished.

Many years ago, while residing in Wisconsin, I conceived the idea of writing a book on the black bass, in order to do justice to a fish that seemed to be but little understood, and likewise to divest the sport of black bass angling, as it then existed, of some of its primitive and disagreeable features, and give it a higher place in the catalogue of noble sports.

I was convinced that it was only necessary to present the claims of the black bass in a proper light, and to give a description of the most suitable tackle for its capture, to induce the angling fraternity to accord full justice to a noble fish, which I felt satisfied was, for several reasons, destined to become the leading game-fish of America.

Accordingly, I began making notes of my observations of the habits of the black bass, and was collecting ciata for the intended treatise, when, fortunately and opportunely, Mr. Charles Hallock founded and established that excellent journal, "Forest and Stream," which came just when it was most needed. Here then was my opportunity to reach the anglers of the country, and I was not slow to 
embrace it, and at once began to champion the cause of the black bass.

I prepared a series of articles on the black bass and black bass angling, and described at some length the proper rod, reel, line, hook, etc., and mode of using them, to render it not only feasible, but practicable, to convince the angler of the high order of game qualities inherent to the black bass, and that by the use of suitable tackle it would not suffer by a comparison with other game-fishes. The seed of these articles was sown in good ground, and yielded abundantly. I received letters from hundreds of black hass anglers, in all parts of the country, thanking and complimenting me for the ideas suggested, and for espousing the cause of their farorite fish, the black bass. The result proved far beyond my most hopeful anticipations, and $I$ have the satisfaction of lnowing that to-day there is no game-fish more eagerly sought for, and none that is being more rapidly introduced into new waters by its adrocates and admirers.

In Feluruary, 18\%5. I contributed an article, entitled "The Coming Black Bass Rod," to "Forest and Stream," which gave a tescription of my idea of a proper rod for black bass angling, founded on many years experience, and the use of many different rods for this purpose. Mr. C. F. Orvis, of Manchester, Termont, at once began the manufacture of a black bass rod from those suggestions, and he was soon followed by other manufacturers, who, seeing the necessity for a new departure from the old beaten path, soon began to make short and light black bass rods more in accordance with the spirit of the age and the demands of their customers, and thus replaced the former long, heary and clumsy affairs by the elegant, short, light and pliant rod of the present day. And not only has the length 
and weight of bait rods been reduced, but fly rods of all patterns have been much reduced in length, during the past fifteen years, to their great advantage.

\section{The Henshall Black Bass Minnow Rod.}

While a rod may vary somewhat, according to the mode of angling, there is no good reason for such a wide diversity of opinion as obtains on the question of black bass rods. For instance: Fishing from the bank of a swift and narrow stream, wading the bars of a wide river, or fishing from a boat on a quiet lake, seem in themselves apparently rery different processes; but in reality they are only slightly different means of securing the same end - the capture of the black bass with a minnow for bait, for my remarks apply only to bait fishing, and a properly constructed rod would answer in either place and fulfill either condition, when accompanied by a light, freely-rendering reel, together with a fine line. An artistic angler, fishing for trout or black bass with the fly, would use his fly rod in either place - from a boat, fïom the bank, or while wading the stream; he would use the same rod under any and every circumstance, wherever he had room to make a cast. The black bass bait fisher will in time become as consistent as the fly fisher, but it will only be when he adopts the proper rod, which rod I will now endeavor to describe.

I start out with the proposition that a first-class American, single-handed trout fly rod is, per se, the rery perfection of rods and the chef'docurre of the rod-maker's art. Such a rod for general work is about ten feet long, and is made of split-bamboo, or a combination of ash and lancewood, weighing from six to eight ounces. With such a rod, properly handled, either line, leader or hook may part, 
but the rod will remain intact. It combines all the essential qualities of a good rod, viz: balance, lightness, strength, elasticity, and pliancy. A salmon rod is only a trout fly' rod enlarged, proportionately, in every particular, and made to be used with two hands instead of one.

Now, if all fish were caught with the fly, there would be no need for other rods than trout and salmon fly rods; but as such, unfortunately, is not the case, we are compelled to adopt other rods in accordance with the mode of fishing, the character of the fish to be caught, and the kind of bait to be used. But whatever may be the nature of the rod that is to be made, let this general rule or principle be followed in its construction: Let the rod conform as nearly as possible to the typical rod, i. e., the trout fly rod, as is consistent with the manner of service required of it. If we follow this rule we can not go very far astray.

Acting upon this principle, then, I have found in my experience that the essential qualities or attributes of a good black bass rod for bait-fishing, are much the same as the typical rod for balance, weight, strength, and elasticity. but stiffer, or not so supple. The slight stiffening of the rod makes it correspondingly heavier, and in order to maintain the same relative weight, we must cut down the length of the rod to eight or eight and a half feet, which is found by experience to be far superior to longer rods for black bass fishing.

As a comparatively long, pliant rod is best for casting a fly, so is a short, stiffish rod best for casting a minnow. With a rod of this character, and a free-running, multiplying reel, it is an easy matter to cast from thirty to forty yards. The situation of the reel upon the butt must be a compromise between the single and double-handed fly rods; for though the rod is used almost entirely with one hand, 
yet there are emergencies when both hands must be used, for occasionally a six-pound bass or a fifteen-pound pickerel, pike-perch, or catfish will be hooked, or an unusually bold or fierce fighting bass may get the adrantage of one and take to the weeds or rocks. It is also essential to have enough room for the hand below the reel in casting. as the thumb must control the running off of the line, and prevent the reel from orerrunning or backlashing. It must have light standing guides, instead of the rings used on the fly rod.

The rod from which my original description of tho "Coming Black Bass Rod" was taken was eight feet and three inches long, in thiree joints; the first joint or butt was composed of white ash, and the second joint and tip of lancewood; it weighed just eight ounces; it was finely halanced, with a true bend from butt piece to tip; with it I killed hundreds of black bass. weighing from two to six pounds, and pike from five to fifteen pounds. I used it many seasons, and failed to see where it could be improved. I oftentimes cast out my entire line of fifty yards when casting with the wind. I felt justly proud of the merits of the rod, for I made it myself.

\section{Standard Henshall Rod.}

The following are the correct specifications of the rod just described; it should be borne in mind that the diameters are of the wood, or more properly of the inside diameter of the female ferrule, where the joints are concerned; also that the joints are flush, or non-doweled, and with reel-bands instead of a solid metal reel-seat:

Total length of rod, 8 feet, 3 inches.

Length of each piece (without ferrule), 33 inches. 
Length of grip (from extreme butt to reel-seat), 7 inches.

Length of reel-seat, 4 inches.

Diameter of greatest bulge of grip, 1 inch.

Diameter of butt cap, $3 / 4$ of an inch.

Diameter of reel-seat, $7 / 8$ of an inch.

Diameter of small end of butt piece, $3 / 8$ of an inch.

Diameter of small end of second piece, $1 / 4$ of an inch.

Diameter of extreme tip, $3 / 32$ of an inch.

From the reel-seat to the end of butt piece is a gradual taper.

The specifications and measurements as given above are also correct for a split-bamboo rod where reel-bands are used instead of a solid metal reel-seat, and a rod thus constructed will weigh but eight ounces; but if a metal reelseat is preferred, with the butt-pice tapering rapidly from it (instead of a gradual taper), ferrules of $\frac{1}{6-}$ of an inch less diameter may be employed, making a rod of eight ounces, or with reel-bands, of seren and one-half ounces in weight.

When the butt of the IIenshall rod is constructed of any wood hearier than ash - that is, when the entire rod is made of split-bamboo, lancewood, bethabara, or greenheart - the best plan, in order that the weight of the rod may not exceed eight ounces, and that its balance and action be not impaired, is to use a short "handle" of lighter wood.

I have always been partial to a butt-piece, including the "grip," being fashioned from a single piece of wood, and with recl-bands instead of a metal reel-seat; and where this is done, with an artistically-fashioned, swelling handpiece, and with a graceful hollow taper from the reel-seat to the rod proper, it presents, to my eye, a certain adaptive beauty and fitness that I fail to see in the short, stubby handle affixed to many modern rods. Howerer, this is best accomplished with some such light wood as ash, black walnut, or red cedar; and where a heavier wood, or split-bam- 
boo, is used for butt-pieces, the short handle of lighter material, if artistically fashioned, is perhaps the better way in order to preserve the qualities of pliability and balance.

The handle comprises the grip, reel-seat, and from two to four inches above the reel-seat, making a handle of from thirteen to fifteen inches long, into which the butt-piece proper is inserted, the joint being closed by a tapered metal collar or winding check.

The diameter of the lower end of the butt-piece (where it joins the handle) should not exceed the diameter of the upper, or smaller end of the butt-piece, more than oneeighth of an inch; that is, the inside diameter of the winding check must not be greater than one-half inch, where a three-eighths ferrule is used on the smaller end.

There are various ways of finishing the "grip" of the handle, which may be formed of the same wood as the handle, and smoothed and polished, presenting a very beautiful appearance. Where it is desired to obtain a firmer hold of the hand, it may be grooved with fine transverse corrugations, or be fluted longitudinally. Another method is to wrap the grip with cord, or strips of rattan; or the grip may be fashioned of hard rubber, and may be smooth, or corrugated, or fluted. The best grip, however, is one of cork, which allows a firmer hold of the hand than any other material, and being lighter, can be of larger caliber.

Some rod manufacturers depart from these specifications by making the grip of the butt several inches longer, but this only adds to the weight and length of the rod without being of any real benefit; on the contrary, it is a positive disadvantage to single-handed rods to have a grip, or handpiece, extending from nine to twelve inches below the reelseat. 


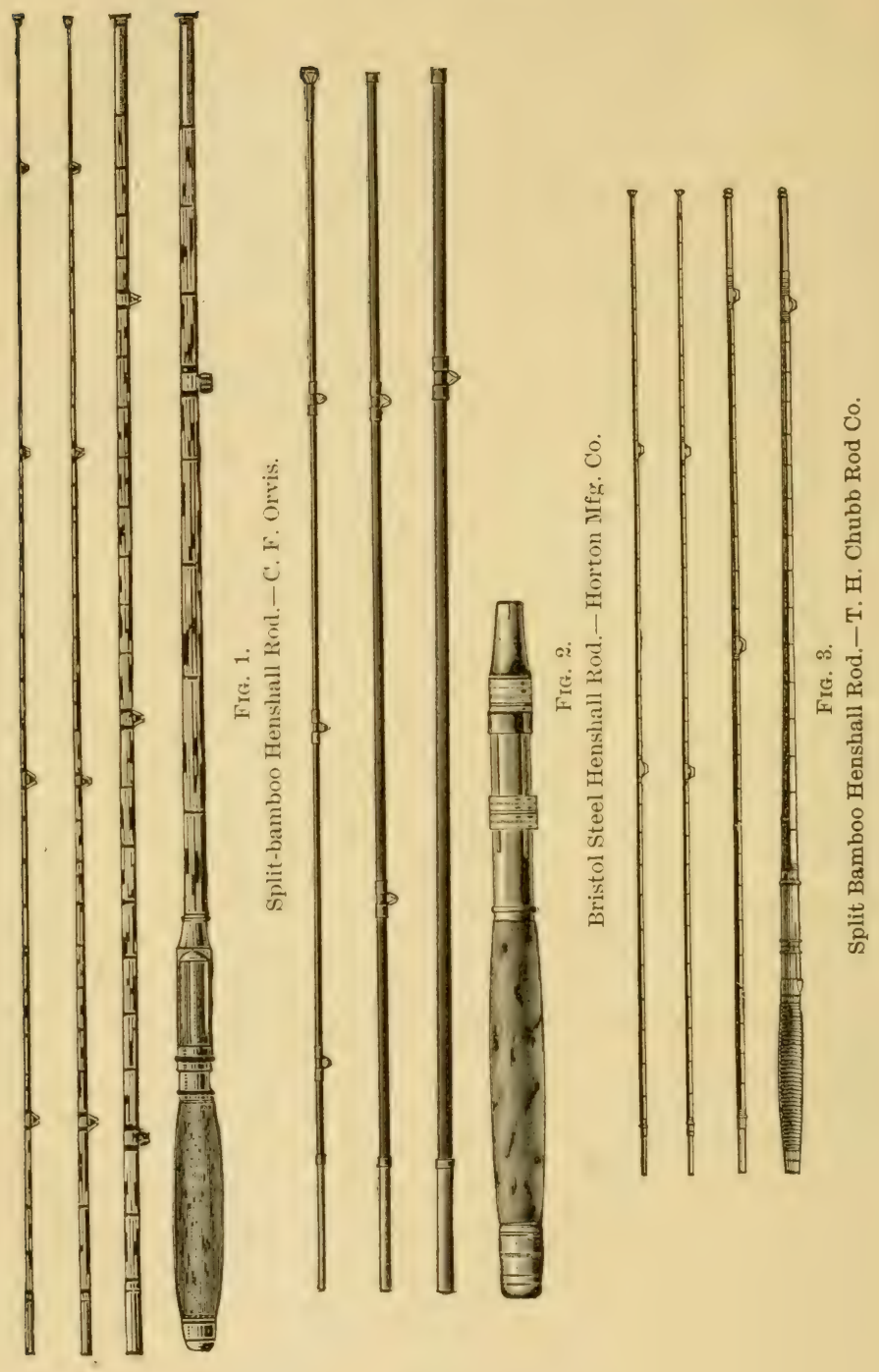


The following measurements are of a Leonard split-bamboo Henshall rod that I have used for many years:

Total length of rod, 8 feet, 1 inch.

Length of grip, 6 inches.

Greatest bulge of grip, 1 inch.

Length of reel-seat, 4 inches.

Diameter of reel-seat, $7 / 8$ of an inch.

Diameter of butt piece at handle, $13 / 32$ of an inch.

Diameter of butt piece at small end, 11/32 of an inch.

Diameter of second piece at small end, $7 / 32$ of an inch.

Diameter of extreme tip, $3 / 32$ of an inch.

Weight of rod, $61 / 2$ ounces.

This rod from being especially well made, and of selected material, is as powerful as an eight-ounce ash and lancewood rod. By comparing its measurements with the standard rod of eight ounces, before given, a rod of intermediate weight may be constructed by slightly increasing the diameters of the Leonard rod, said diameters being of the male ferrules.

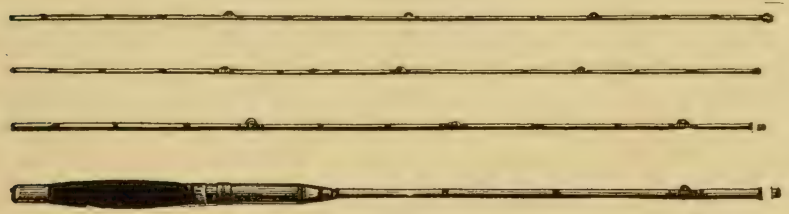

FIG. 4.

The bethabara Henshall rod, of the standard length and proportion, is somewhat heavier than one of ash and lancewood, but preferred by many on that account. In other qualities it is an excellent rod, more resilient than greenheart or lancewood, and is spoken of in the highest terms by those who have used it. I can heartily recommend it, 
also, having had much practical experience with it. Malcolm A. Shipley, Philadelphia, makes a specialty of bethabara rods.

The standard Henshall rod, of ash and lancewood, has a true and gradual taper from the reel-seat to the tip, which gives it a back, which, while just stiff enough for casting a minnow, is sufficiently pliable and yielding to give a correct working to the rod under the play of a lively fish. And just here is where so many rods fail - they are made too weak in the butt-piece, or the upper two-thirds of it, usually by a rapid and concave taper to reduce the caliber of the rod at this point, in order to gain lightness. But this can only be done at the expense of weakening the rod, and spoiling its action.

When a rod has too weak a back, or too slender a butt at this point, it causes the rod to be top-heavy, and produces what is linown as a "double action" in the rod, or a "kick in the handle;" qualities which were sought for in some salmon fly rods in the old country, as it was supposed that a fly could be cast farther with rods of this character. But it was necessary that the angler should become thoroughly educated in the handling of a rod with this peculiarity to be enabled to use it with any degree of satisfaction.

However much this principle may have been desired by British salmon fishers, it becomes the very worst feature in a black bass minnow rod. With this defect in a bait rod, it is impossible to cast with any accuracy, or to any great distance. And, morenver, it produces in the angler a lack of confidence in his rod, for it "feels weak" to him at the very point where it should feel the strongest, and really the rod would give way at just this very point under a heavy strain. 
But, to refer to my rod again: I can easily cast a minnow from forty to fifty yards, and with great accuracy, the back being just stiff and yielding enough for this purpose. The bend from the last third of the butt-piece to the tip forms a true curve under the strain of a hardpulling fish, which is the bend so desirable, and so hard to obtain. The strain falls equally upon the entire rod, so that it is impossible for me to tell just where it would break. The weak part of an imperfect rod can always be felt by an expert angler, and he knows perfectly well, while playing a fish, just where the rod is weakest, and just where it would fail.

I have been informed by some makers that occasionally an angler will order a Henshall rod with the butt extending below the reel clamps a foot or more, so as to reach under the elbow, and thus form a point d'appui. This demand is founded on the use of the old-style rods, which were so heavy and long as to require either this support, or what was worse, the holding of the rod with both hands. The object of the modern black bass rod is to dispense entirely with this ungraceful and clumsy style, and enable the rod to be used with the hand alone, as in fly fishing.

The novice will be sometimes told by theoretical anglers that he must procure a rod which accords with his size, strength, and general build; that a rod which suits one angler, will be too long, too short, too heavy, or too light for another. Now, this is all gammon; a rod must be made to suit the kind of fish, and the mode of fishing, without any reference whatever to the angler himself.

In ordering a shot-gun that is to be used on all kinds of game, from the lordly buck to the dainty quail, it is of the highest importance that the gun should be built to fit the sportsman in every particular, and he then varies the charge 
according to the game. But there is no analogy between . a shot-gun and a fishing rod; the latter weighs but ounces, where the former weighs pounds, and the weight of a rod for black bass angling will suit a weakly youth, or the strongest man, as well. A half-pound in weight is of no moment as compared to the strength of a man; and it is all stuff, and the sheerest nonsense, to talk of making a rod of this weight conform to the moscular requirements of any individual. A well-balanced rod feels the same to the weakest man or strongest, the tallest man or shortest; while a rod that lacks this quality will feel right to no one. I have no patience or sympathy with those visionary bookanglers who talk or write such ridiculous nonsense or spin such fine-drawn theories.

\section{A Holie-made Black Bass Rod.}

As the black bass anglers of Ohio, Kentucky, Tennessee, northern Alabama, and the south-west generally are extremely partial to a natural cane or bamboo rod, I desire to tell them how to make a good one of this material at little cost, and which, though not a "thing of beauty," will prove itself a "joy forever," in comparison with the cane rod, as generally used. After employing such a rod as I am about to describe for one season, the angler will be ready to advance another step, and adopt a good ash and lancewood rod, which contingeney, I am free to admit, is the principal motive for this information.

A natural bamboo cane, as it is procured at the tackle stores, is from fifteen to twenty feet in length; and it is the custom, in the localities named, to use from ten to twelve feet of the smaller or upper end of such a cane for a black bass rod, after attaching standing guides and a reel fastening. While such a rod is strong and light, with a 
moderate degree of pliancy and elasticity, it entirely lacks the great desideratum, balance, being decidedly top-heary, and is too small at the butt to allow of a firm grasp of the hand, generally necessitating the use of both hands to hold it. Now, to obtain the greatest amount of good and pleasure from a rod of this character, proceed as follows:

Select a genuine Calcutta bamboo cane, which may be known by its dark, mottled markings, caused by its having been burnt about the leaf-ridges, or knots. Select one that is hard and elastic, with a good taper, and quite small at the tip; those known as " male" canes are the best, having larger bulges, or leaf-ridges, and being much tougher than the "female" canes. Haring chosen a good one, cut off six and a half feet of the smaller end for the rod; the remaining larger portion of the cane will make a good handle for a landing-net.

Now make a wooden butt of white-ash or black-walnut, from eighteen to twenty inches long, of the following diameters: At the extreme butt end, seven-eighths of an inch; now increase the diameter by a gradual taper to an inch and one-eighth at a distance of five inches from the extreme butt; then decrease the taper to an inch at a distance of seven inches from extreme butt. The next four inches forms the reel seat, and is one inch in diameter throughout its length; now decrease the diameter by a rapid, concare taper for a distance of two inches, to threefourths of an inch, and thence a gradual taper to the smaller end of the butt, which must exceed the diameter of the large end of the cane about one-sixteenth of an inch; the diameter of the large end of the cane-jointwhere cut in two-will be from half an inch to fiveeighths of an inch.

Having proceeded according to the instructions just 
given, we have a cane joint six feet and six inches long, and a wooden butt say twenty inches long, with the grip of one and one-eighth of an inch in diameter, and the reel seat of one inch diameter. Now procure a set of reel bands one inch inside diameter; a pair of ferrules for the joint - the inside diameter of the smaller or male ferrule being of the same diameter as the large end of the cane piece, which can readily be ascertained with a pair of calipers; five standing guides, graduated sizes, and a solid metal tip. These mountings should be brass or German silver. The guides should be attached at equal distances from the reel seat to the tip; and, having properly fitted the ferrules and reel bands, give the rod two coats of shellac or coach varnish. When dry, the rod is ready for use, and will be about eight feet in length, and weighing from six to eight ounees - a single-handed rod equal to any rod made for casting. will be well-balanced and strong, hut will lack the pliancy, resiliency and perfect working of a good ash and lancewood rod, yet it will be such a great improvement on the cane rod, as generally used, that it has only to be tried to be appreciated.

\section{Non-DOWELED JoINT.}

One of the specifications of the Henshall rod is that the joints be mate flush, with short, cylindrical ferrules, instead of the old-fashioned tapered ferrule with dowel and mortice; and as so many of these rods have been sold during the past twenty years, it has had a great tendency to introduce and popularize this form of joint, which is now also applied to most fly rods to their great advantage.

It is now forty years since I made my first rod with flush joints, having, at that time never heard of or seen a 

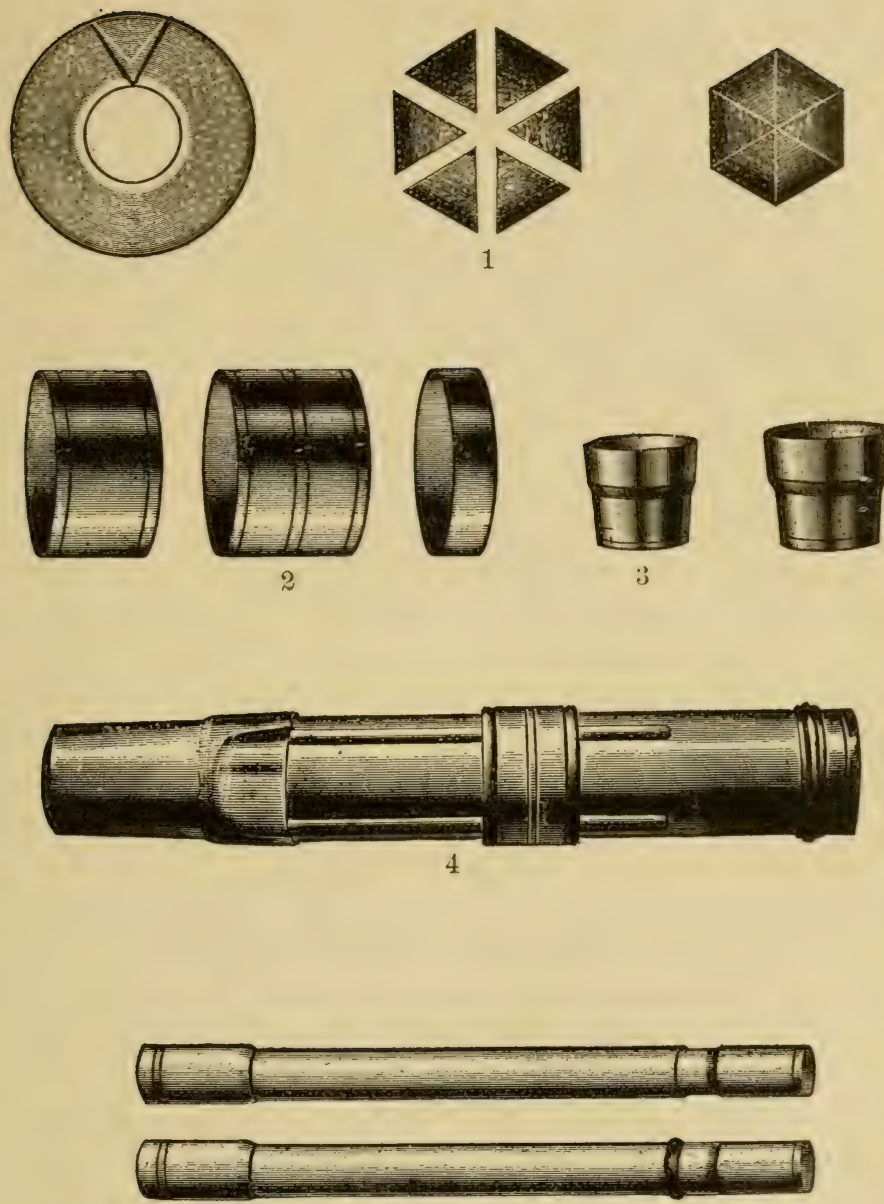

5

1. Cross sections of Split-Bamboo Rod-Strips. 2. Reel Bands.

3. Winding

Checks.

4. Metal Reel-Seat.

5. Capped Ferrules. 
rod joint without dowels, and ever since I have been a firm believer in this improved joint. If there were wanting any proof of the practical superiority of the non-dowel joint over the dowel and mortise joint, it would be found in the fact that so many old anglers, as Thaddeus Norris, Reuben Wood, and Chas. F. Orvis, having the mechanical skill to construct their own rods, discarded the latter for the former style of joint many years ago. And, moreover, they all seem to have arrived at this determination and conclusion independently of each other. Many of the most valuable improvements and inventions have been made in like manner, each one supposing himself to be the sole inventor.

I have often thrown apart the tapered and doweled joints of the old style rods in casting with both fly and bait rods. and have har them brak near the lower end of the female ferrule, in consequence of too deep a mortise at that point; but with the cylindrical, non-dowel joint I have never had either accident to occur.

The canse of the separation and throwing apart of the dowel-mortise joint I conceive to be this: The ferrule, dowel, and mortise being mate tapering, the male ferrule with its dowel acts as a wedge, and the continual springing of the rod in casting tends to loosen this wedge, and to eventually separate the joint, in the same way that we extract a nail by working it from side to side. This fact can be easily demonstrated by separating the tapered dowel joint by working it back and forth in this manner, with the hands close to the ferrules. But it cannot be done with the flush cylindrical ferrule joint; to separate the latter it is necessary to pull or twist it apart, for no amount of springing it back and forth will loosen it. This fact renders nugatory and superfluous all locking devices, screws, 
cleats, and strings, which have been proposed to secure the joint, and prevent its separation in casting.

Ferrules should be short, and perfectly cylindrical. It is not necessary for the female butt ferrule to exceed two and a half inches in length, nor two inches for the second joint. The male ferrules should be of a corresponding length, say one inch, which will give all the "hold" required. The ferrules should be perfectly fitted to each other throughout their entire extent. The lower end of the male ferrule, and the bottom of the female ferrule should be protected by metal caps or disks, soldered on, to exclude moisture. The ferrules should be fitted without cutting the wood, and a wrapping of silk put on at the ends for a finish. A good plan is to wrap on a guide or ring immediately below the female ferrules, so that the upper wrapping of the guide extends to the ferrule, which thus serves a double purpose.

Swell ferrules are unnecessary, and are neither so good nor strong as cylindrical and uniform ones. The ends of the ferrules may, however, be split, or scrrated, or be swaged into a hexagonal form for split-bamboo rods, to give a more perfect fit, without any disadvantage in other ways. Ferrules may be banded if the metal is very thin, which is apt to he the case with those drawn from German silver, which cannot be drawn so thick as brass. Ferrules should be affixed with shellac or cement instead of using a metal pin, which has a tendency to weaken the rod, and renders the removal of the ferrule more difficult for the purpose of repair.

\section{The Little Giant Rod.}

On page 91 is mentioned the hibernation of hlack bass under the ledges and in the crevices of the reefs about the 

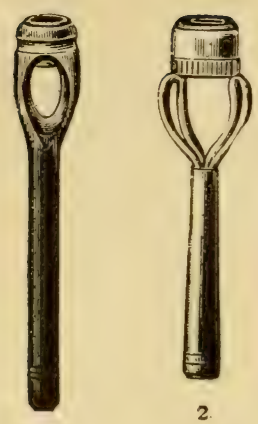

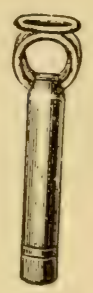

3

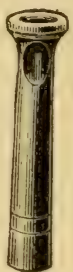

4

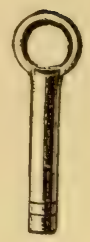

5

I

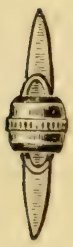

I

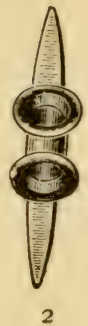

2
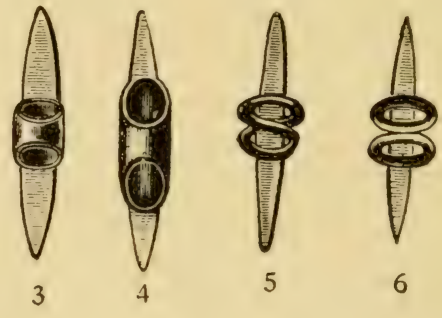

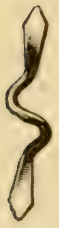

3

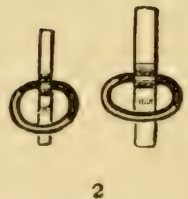

RoD Trps.

2. Basket agate.

5. One ring.
1. Solid agate.

4. Tube.

1. Agate.

4. Anti-friction.

Standing Guides.
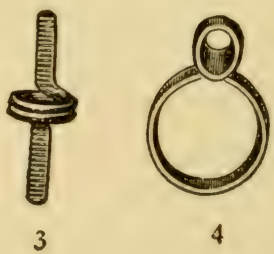

2. Trumpet.

5. Twisted.

RING GuIDES.

1. Snake. 2. Rings and keepers. 3. Spiral. 4. Standing ring. 
islands in the west end of Lake Erie. When the bass energe from their winter quarters in the spring, and likewise in the fall before retiring for their seclusion during the winter, they linger about the reefs for several weeks in water from ten to twenty feet deep. They are fished for at these periods with live minnows, and in order to keep the bait near the reefs comparatively heavy sinkers are employed, which requires a rather stiff rod. To meet this method of angling I devised a modification of the Henshall rod which has been styled the "little giant." It is made in two pieces with but one joint. Its measurements, when constructed of ash and lancewood, that is, with ash butt piece and lancewood, greenheart, or bethabara upper piece, are as follows:

Total length of rod, $71 / 2$ feet.

Length of grip, below reel-seat, 8 inches.

Length of reel-seat, 4 inches.

Greatest bulge of grip, 11/8 inches.

Diameter of recl-seat, $7 / 8$ of an inch.

Diameter of male ferrule of joint, 11/32 of an inch.

Diameter of extreme tip, $1 / 3$ of an inch.

Weight of rod, 8 ounces.

It may be made somewhat lighter in split-bamboo with a short wooden handle, but where sinkers of two or three cunces are used, eight ounces will be found light enough. This rod may be utilized for coast fishing, where sinkers of various weights are necessary in the tideways, for fish up to ten or fifteen pounds. Some anglers prefer it for black bass fishing under all circumstances.

\section{The Frog-casting Rod.}

Since the advantages of the short Henshall rod nave been acknowledged, and the relegation of the long and 
heary rods of the olden time has been effected, there has arisen a new departure in black bass rods that out-herods Herod. Rods - we must call them so by courtesy - are now made from four to six feet long for casting the live frog or pork rind, in boat fishing. The casting is done overhead and forward, as in fly fishing, and the frog, being recled up to the tip, is projected in the manner of throwing a small apple from the end of a slender stick; or, if the fisherman be seated, it is thrown to either side.

It is possible to cast with much accuracy in this manner; and in weedy waters, where the playing of a hooked fish is a matter of extreme difficulty, it has its advantages; for the rod being not only very short, but very stiff, the fish can be reeled rapidly to the landing net. This mode of angling, however, does not appeal to one who has a just appreciation of the amenities of the gentle art and a love for suitable tackle, or to one who, being imbued with the proper esprit de corps, is disposed to give the fish a chance. There are some of my friends who, believing that the end justifies the means, practice frog-casting with such rods with much enthusiasm - they have my sympathy. Some really expensive rods are made for this method of fishing; with agate-lined guiries and ivory-tipped handle, when fashioned in split-bamboo.

\section{Bristol Steel Rod.}

Anglers have been wont to say of good rods that they were as pliable and strong as steel, or were steel-like in action, little thinking that a real rod of steel would ever be made. Such a thing had been talked of as one of the possibilities. but I never imagined how it could be successfully accomplished. I knew that a solid steel rod would be far too heary, and I could not understand how a steel 
tube could be made with "play" enough to answer the requirements of a fishing rod.

The difficulty has been solved, however, in the Bristol steel rod, made by the Horton Manufacturing Company, which is composed of three tapering steel tubes. Each tube is formed of a thin strip of steel, bent around a mandrel, the edges in close apposition, but not brazed; and therein lies the whole secret, for, being practically a slit tube, it admits of a twisting as well as a bending motion, thus simulating the action of a wooklen rod; the twisting motion could not be obtained in a brazed or drawn tube. The tubes are exceedingly well tempered, which I imagine is one of the most important features of their construction.

I have a Henshall Bristol steel rod, eight feet six inches in length, and weighing ten ounces, which shows to what a state of perfection the steel rod has reached since it was first introduced. The joints have brass, non-doweled ferrules, and with cork grip and agate-lined guides and tip, it will compare farorably with a good wooden rod for style and appearance, and in action is not far behind it, while for strength it is far ahead. For those anglers who prefer a stout, heary rod, and one that will stand rough usage, and who fish where mascalonge and pike abound, or who resort to the waters of Florida where large bass are the rule, they will find in this rod their heart's desire.

\section{The Black Bass Fly Rod.}

A few pages back, I made the statement that the American trout fly rod was the very perfection of fishing rods, and that all other rods should conform as nearly as possible to sair model or typical rod, commensurate with the 
manner of service required of them. Upon this principle an honest and well-made trout fly rod of good weight and length answers for black bass fiy fishing; and, fortunately, a suitable rod of this character can be procured from any first-class maker; but I would caution the new hand against the many cheap rods now in the market. A good rod can only be obtained at a fair price.

To propel so light an ohject as a cast of flies one humdred feet or more requires an instrument of propulsion as perfect as a rod can be made. Hence a fly rod must have stability and power. or batelibone, in the lower third of the rod, with sufficient pliancy and resiliency in the upler two-thirds to respond to and augment the initial projective foree apjlied by the arm of the angler. All fly rods should be made in accordance with this principle; and it is only a question of propontion as between the heaviest salmon rod and the lightest trout rod. It is somewhat on the principle of a long coach whip with a stiffish butt and flexible top, which enables the driver to flick a fly from the flank of a leader in a four-in-hand with ease and precision.

Single-handed fly rods are from nine to eleven feet long: and weigh from three to eight ounces. The heavier rods are for black bass and large trout, and the lightest for small trout. Comparatively light rods are now made powerful enough to cast nearly a hundred feet, and of sufficient strength to kill the largest brook trout. The pleasures of angling are much enhanced hy the employment of a light rod, which permits the angler to cast for hours without fatigue, whereas with the old long and heary rod it was at best a labor of love. The best material is split-bamboo, when of first quality, though lancewood, greenheart, or bethabara is more serviceable in the long 
run, and if made by a master hand is almost as satisfactory, especially for the heavier rods.

A trout fly rod, then, weighing six or seren ounces, and not more tham ten and a quarter feet long, is just about right for ordinary black bass fly-fishing; but where the bass run large, areraging nearly or quite three pounds, a somewhat hearier rod, say seven and a half or eight ounces, will be found a more suitable and pleasanter rod to handle, though the six-ounce rod will do even here, for one who is an expert fly-fisher, and who does not mind a little extra straining of the brachial muscles, to say nothing of the rod.

But while an ounce, more or less, hardly seems an appreciable quantity in the abstract, yet when added to or taken from a fly rod, like the fraction of an inch as applied to a man's nose, it makes a very great difference in practice and reality; and in the former case, it is better to have an ounce too much, than a half ounce too little; for, like the repeating rifle when tackling a grizzly, it gives one a confidence in his resources which adds materially to the zest of his sport.

It must be borne in mind, however, that it is not the largest bass that rise to the fly, and a lighter rod can, consequently, be used than in bait fishing; though where the bass run exceptionally large, and esperially for the waters of Florida, six inches in length and an ounce in weight may be added.

The rod should have a stiffer back than most trout fly rods of the same weight and length, but should still retain nearly the same pliancy. though necessarily most of the flexibility will be in the upper two-thirds of the rod. This gires pliancy for casting. resiliency for striking, and plenty of "backbone" for playing and landing the fish. Of course, a trout rod of about these dimensions will answer 

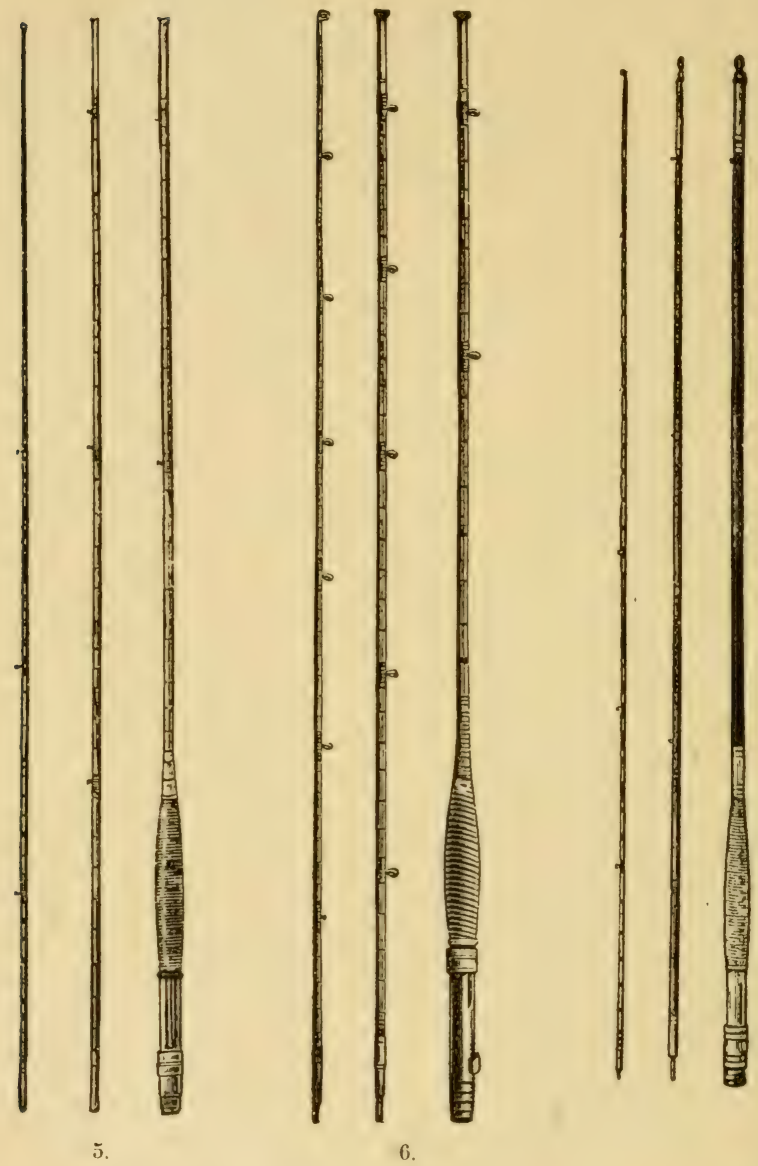

5. Split-Bamboo Fly Rod.-Abbey \& Imbrie.

6. Split-Bamboo Fly Rod.-Wm. Mills \& Son.

7. Bethabara Fly Rod.- Halcolm A. Shipley. 
very well for black bass fishing, but as the flies to be used are generally larger than trout flies, and as the bass is usually a much heavier fish than the brook trout, the rod will require a little more backbone than is usually found in trout rods.

To obtain the necessary spring, snap, and stiffish back required in a black bass fly rod, much consideration must be given to the material of which it is to be constructed. In my opinion, there is no material that combines so many good and essential qualities as split-bamboo, if of the best quality, and if it is made up in a first-class manner. It is strong, flexible, comparatively light, and is the most resilient material used in rod-making, approaching steel more nearly in this quality than any other wood. Ash and lancewood, greenheart, bethabara, and some other woods, when carefully selected, make excellent rods, but the best are inferior to a good split-bamboo rod. On the other hand, a first-class bethabara, or ash and lancewood fly-rod, is better than most split-bamboo rods as now made.

It must be borne in mind that the action of the modern shorter and stiffer fly rod differs from the former long and willowy rod of English pattern. With the improved form the action in casting is quicker and somewhat jerky, while with the longer and more supple rod the action was slow, deliberate and more graceful, but required more force to get out a good length of line.

The fly rod has the reel-seat at the extreme end of the butt, and the hand-piece, or grip, of course, above it; for the click-reel, which is used for fly-fishing, is a reel that is intended to "take care of itself" in the rendering of the line, and, therefore, is very properly placed where it is out of the way, and where it adds very much to the balance and general working of the rod. 
The reel-seat in fly rods is often made entirely of metal and which, while much admired by many, only adds to the weight of the rod, without being of material service. For myself, I prefer a plain reel-seat, simply a depression, or groove, cut in the butt of the rod, with reel-bands, as in the minnow rod. This answers every purpose, and to my mind there is nothing that can improve the beauty of a handsomely finished wooden butt; and on this account, I am also prejudiced against the hand-piece, or grip, being wound with cord or rattan. The self-wood, of which the butt is composed, seems to me to be the best and most appropriate finish for the grip, both as regards utility and beauty; for the cord, or rattan, with which the grip is usually wound, in fine rods, is extremely liable to become loosened and worn off.

The wound hand-piece and the metal reel-seat look very attractive, but are not proof against wear and tear; and for my own use, and in accordance with my idea of the fitness of things, I think the less a rorl is encumbered with fanciful and ornamental appendages, the better. We should ever bear in mind the original primitive cane fishing pole, upon which model all rods are founded, more or less, and remember that simplicity and utility usually go hand in hand.

\section{The Henshall Black Bass Fly Rod.}

The specifications for this rod, in lancerrood, and weighing seven and one-half ounces, are as follows:

Total length of rod, 10 feet, 2 inches.

Length of each piece, without ferrule, 41 inches.

Length of handle, from extreme butt to top of winding check, 12 inches.

Length of reel-seat, 4 inches. 
Diameter of reel-seat, $3 / 4$ of an inch.

Length of grip, 7 inches.

Diameter of greatest bulge of grip, 15/16 of an inch.

Diameter of butt-piece at handle-joint, 15/32 of an inch.

Diameter of male ferrule, butt-piece, $3 / 8$ of an inch.

Diameter of male ferrule, second piece, 15/64 of an inch.

Diameter, extreme tip, $\tilde{5} / 64$ of an inch.

It will be observed that while the ferrules used in this rod are the same as those in a short-handled Henshall minnow-casting rod of split-bamboo, the greater length of the several pieces in the fly rod gives it greater pliancy. It will be understood also that the joints are flush, or nondoweled, as in the same rod.

The ferrules, reel-bands and butt-cap should be either solid brass, or German silver, without plating of any kind; let us have the real thing at all events. for I despise affectation, or deception, in any matter or thing whatever. Brass is a good, honest, and bright metal, will not rust or tarnish, and if it is used at all let us use it on its merits, and for deceney's sake aroid the common practice of plating it with nickel, or, what is worse, silver, for the plating soon wears off and exposes the cheat.

Rings, instead of standing guides, are used, as they are lighter, and on the fly rod answer just as well; they are lashed on with spool-silk by means of small metal strips, known as "keepers." The rings should graduate in size from the butt to the tip, and should be of the same metal as the ferrules. The metal tip of the fly-rod is a single ring, which is preferable to a solid tip, or the three-ring style, on account of its extreme lightness, for it will be remembered that the tip, or top, of a fly-rod is of very small caliber. 


\section{CHAPTER X。}

\section{FISHING REELS.}

"And to that end, some use a wheel about the middle of the rod, or near their hand; which is to be observed better by seeing one of them, than by a large demonstration of words."-IzAAK WaLTON.

Next to a good rod there is nothing that contributes to the pleasure of the angler so much as a well-made reliable reel, and I am happy to be able to state that the improvements in fishing reels for black bass fishing have fully kept pace with the improvements in fishing rods. Manufacturers and inventors have taxed their ingenuity in devising the best and most suitable reels for both fly-fishing and bait-fishing, and the American reel, as the American rod, is to-day the best in the world.

The earliest mention of a fishing reel that I am aware of is that recorded in the "C'ompleat Angler" by Izaak Walton, who states, as a matter of horsay, that a "wheel" was sometimes placed about the middle of the rod for winding up the linc. ITe dirl not employ one himself, and probably never saw it used. or he would have been more explicit concerning it. 'The wheel mentioned was doubtless a solid wooken one, of large diameter, with a deep groove in its peripheral borter for the line. Such a winch is in common use to-day in England, and is known as the Nottingham reel.

There are three kinds of reels employed in angling: the click reel, the multiplying reel, and the automatic reel.

A fishing reel is made in accordance with the special service required of it. the objects of said service being twofold. The first and most important is the proper 
delivery of the bait in a manner and at a distance commensurate with the mode of fishing; and the second is to play and land the fish after he is hooked, or to reel the line for another cast. The reel which practically fulfills these conditions with the greatest ease and facility, in the method of fishing practiced, is the best reel to use.

The two modes of angling in which the reel is employed are bait-fishing and fly-fishing, and as the two methods differ so essentially, they require reels of widely different functions. Thus in bait-fishing the multiplying reel is used, while in fly-fishing the click reel is indispensable.

The multiplying reel must not only be very rapid in its action, but the spool must rerolve with the greatest ease and freedom, so as to deliver the bait as far as possible at a single cast, the thumb, meanwhile, controlling the rapid rendering of the line, so as to prevent back-lashing of the spool; but in fly-fishing the line is lengthened gradually, a few feet being taken from the reel by the hand before each subsequent cast, while the click offers the necessary resistance to the rendering of the line to permit this to be done without overrunning.

As the multiplying reel is made wide, so as to allow for the thumbing of the spool, and as this necessity is not required in the click reel, the latter is made quite narrow, thus permitting the line to be reeled without bunching, and, at the same time, allow of its being reeled rapidly enough for all practical purposes, without a multiplying action; for the main object of a multiplying reel, is for facility in casting, and not in retrieving the line, as is often erroneously supposed.

After a fish is hooked, a click reel answers the purpose of playing, and landing it, as well as the best triple or quadruple multiplier made - if not better; for often a fish 
is reeled in by main strength with a multiplier, and an attempt made to land it before it has been killed on the rod, thus curtailing the real sport of angling, and at a great risk to the angler's tackle. I speak of this now, for I have heard anglers praising a rapid-working quadruple multiplying reel, because they could reel in a fish "so fast," basing all of its merits upon this one quality; the desire to get possession of the fish seeming to be paramount to the real sport of hooking and playing it.

\section{The Click Reel.}

The click reel is a single-action reel, and, consequently, is the simplest form of reel, from the fact that the service required of it is simply a slow and gradual lengthening of the line with each subseguent cast, the delivery of the fly being accomplished by pulling off from the reel a few additional feet of the line after each cast, until the desired or maximum distance is reached, while the click offers just enough resistance to the rendering of the line to allow this to be done without confusion or overrunning. The handle, or crank, is connected directly with the axle, or shaft, and, consequently, "recling in" the line would be slow work were it not obviated by the reel being made narrow, so that the coil of line upon the shaft enlarges rapidly, and the reeling is thus accomplished with greater facility.

Its plan of construction is quite simple, and consists of a narrow spool set in a stationary frame, the spool revolving on a central shaft which has a handle at one end and a small spur wheel at the other. The spur wheel engages with a wedge-shaped pawl, which is held in place and controlled by a circular steel spring, allowing motion in either direction. This constitutes the so-called "click," the office of which is to retard to a certain extent the revolving of the spool. When the spool is rapidly revolving under the 
rush of an active fish, the click fairly hums - a sound so pleasant to the angler's ear that it is not inaptly styled the "song of the reel."

In my collection is a click reel made by J. L. Sage, of Lexington, Kentucky, in .1848, for black bass fishing, which he used for many years. It differs from the usual plan of click reels in haring the spur wheel at the same end of the shaft as the handle, and the wheel is larger than customary. The circular spring is brass, which produces a soft musical sound, and one more agreeable than that of most click reels.

Click reels are made of metal or of metal and hard rubber. The handle is either a piain crank or a balance-handle attached directly to the shaft, or, as in some instances, a revolving disk is affixed to the shaft, with a short knoblike handle on its outer rim. The latter form is the most

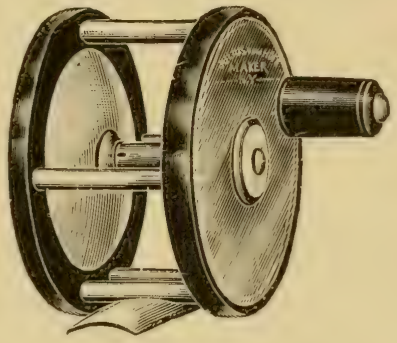

Fig. 1.

Click Reel, with revolving Disk. powerful; moreover the line is not so apt to become fouler on its short, smooth handle. Should one. of the screws

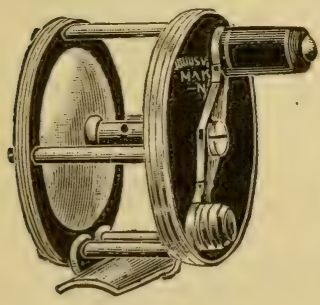

FIG. 2.

Click Reel, with Metal safety band. that fastens the front disk-plate of the reel become loosened and project, as sometimes happens, it interferes with the free revolution of the crank; such a contingency is obviated by the revolving disk. Where a crank-handle is employed, there should be a projecting rim, or safety band, within which the handle revolves, to prevent fouling of the line. 
The balance-handle is a delusion and a snare. There is no real adrantage in it. In so light a piece of machinery

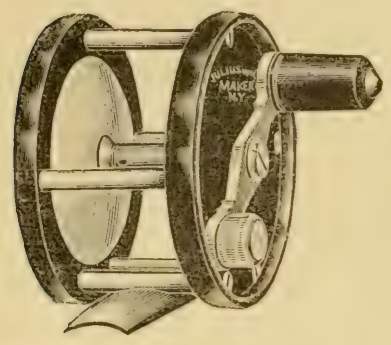

FIG. 3.

Click Reel, with Balance-Hamule and Rubber Protective Rim. as a fishing reel, a balancehandle adds nothing to its efficiency, while it is open to several objections, the most serious of which is the greater possibility of fouling the line as compared with the simple crank-handle. It is popularly supposed to aid in the smooth and rapid revolution of the spool; but if the reel is constructed in a workmanlike mammer. such aid is reduced to a minimmm. It is one of those theories that is not borne out in practice. It was nexrer designed hy a practical angler. The click reed is placerl at the oxtreme hutt of the fly rod, below the hamel-erij, where it arlels much to the balance and general working of the rod. As the click regulates the rendering of the line, and as the narrowness of the reel obviates the necessity for guiding the line in reeling, it is placed out of the way, at the extreme butt. It should always be placed underneath the rod, and not on top, as is often done.

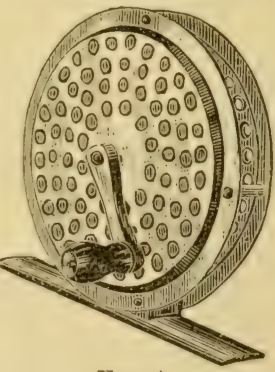

FIG. 4.

Orvis Reel.

Click reels are all constructed upon the same general principle. but are of various patterns and composed of various materials. heing made of hard pubber. celluloid. brass. bronze. and (irmuan silver; their weight depends on the material weel. and the angler has a large assortment of styles and prices to select from. Any good trout click 
reel is suitable for black bass fly-fishing, and can be furnished by any of the first-class dealers.

In the choice of a click reel, the angler should select the lightest, when it is compatible with strength, and one in which there is the least probability of fouling the line on any prominent points, as projecting screws and caps, unprotected handles, etc. Metal reels are the strongest, and not so liable to injury as rubber or celluloid, in case of accidentally dropping, or striking them against rocks, etc.; though the latter are much lighter, and with ordinary care are just as serviceable.

There has been a rery marked improrement in click reels during the past few years, the manufacturers seeming to vie with each other to produce the lightest, neatest, comeliest, and most serviceable reel.

\section{Nultiplying Reels.}

For bait-fishing the multiplying reel is a decided improvement on the old single-action English reel or winch. It is made of metal or hard rubber, and of various styles or sizes. In shape and construction it differs necessarily from the click reel, having a different office to perform, or rather the same object - the delivery of the bait - to perform in a different manner. Being intended for natural bait-fishing, it requires an easy-running and freely-rendering action in order to deliver the bait as far as possible at a single cast. As there is no click to control the running off of the line, the thumb must be used for this purpose, by effecting a gentle and uniform pressure upon the spool, and for this reason the multiplier is made much wider than the click reel, or of the barrel or drum shape.

The principle of construction of the multiplying reel consists of a small pinion on the end of the spool shaft, geared with a larger cog whecl attached to the crank. One 
revolution of the crank produces two, three, or four revolutions of the shaft, depending on the number of teeth in the wheels; thus, in a quadruple or four-time multiplier, there are, say, forty teeth in the wheel and ten teeth in the pinion. The multiplying reel is designed especially for casting a lait, and the better the construction of the reel, the longer the resultant, initial cast.

All fine multiplying reels are now made with an adjustable elick, in order that they may be utilized for fly-fishing. Tarious derices are employed for the purpose. In some, the mechanism is on the back plate of the reel, as in the click reel, and is the sime except that the pawl can be

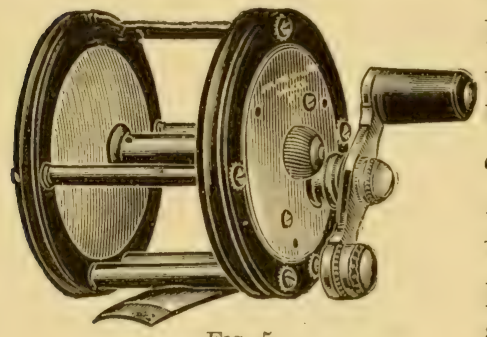

Fig. 5.

Multiplying Reel. thrown in or out of gear by a sliding or turning button. This is by far the best plan, as it can be operated while the reel is in motion. In other reels, the pawl engages with the pinion on the front plate, and is thrown in gear by the same method as the other. In most Kentucky reels the click is used more as an alarm. though it can be utilized as well for fly-fishing if the spring is mate stiff enough. It consists of a piece of watch spring, bent to a T'-shape, and affixed to a block which is operated by a slicling button. The spring engages with the pinion on the front plate of the reel. Various forms of locks and drags are also applied to some multiplying reels, which, however, are only of fancied advantage.

A good single-action reel, without a click, will run almost as freely as a multiplying reel within eertain limits, but the resultant cast will be a short one, as the momentum is soon exhausterl. In the multiplier, however, the mo- 
mentum of the revolving spool is sustained and prolonged by the gearing of the reel, thus allowing a much longer cast to be made.

As stated at the beginning of this chapter there has been marked improvement in multiplying recls for black bass fishing, notably during the past ten years, manufacturers having exercised their inventive faculties in devising reels of superior workmanship, and with various devices for the convenience of the angler.

The principal manufacturers for the trade are Julius rom Hofe, Brooklyn, N. Y.; A. F. Meisselbach \& Bro., Newark, N. J.; The America Company, Rockford, Ill.; and the Andrew B. Hendrix Co., New Haven, Conn. The excellent reels of these firms are kept in stock by all prominent dealers. Where there are so many good reels comparisons are indeed odious, and morenver the price of one is not always a safe criterion of its practical merits.

In addition to the manufacturers for the trade there are the makers of special reels who sell directly to the angler. Of these the well-known hand-made reels of B. C. Milam \& Son, Frankfort, Ky., and A. B. Mcek \& Sons, Louisville, $K y$., are necessarily highest in price owing to the quality of material, the faultless and exquisite workmanship, and the nicety of adjustment employed in their construction. They are now so farorably known that a mere mention is only required here.

The Nilam reel has recently been improved by adding jewelled bearings in which a hole is drilled for the ends of the spool-shaft or pirots; an obvious advantage in lessening friction and faroring freedom of action.

The Meek reel, as now made, also runs on fine jewels of exceeding hardness. With its bevel gearing there is absolutely no lost motion and runs as smoothly as though the power from wheel to pinion was transmitted by a belt. In 
all other respects it is unexcelled in its class - it is a work of art. The fortunate angler who possesses either a "Meek" or a "Milam" reel is to be congratulated.

In this connection, and in riew of these recent improrements. it is worthy of note that the personal and farorite reel of (reorge snyder, made in 1810, and which was at one time in my lieeping, had garnet jewel bearings.

One of the finest hand-made reels, with the latest

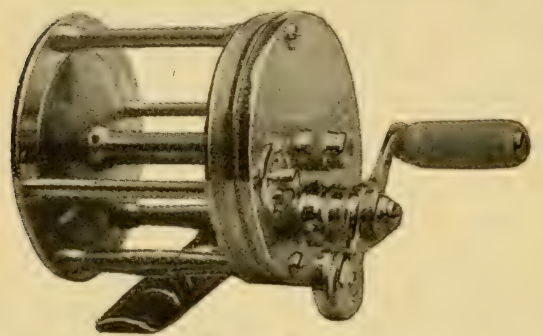

Talbot Reel. improvements, is that of the W. H. 'T'albot Co., Nevada, Mo. It is made in several styles, of German silver, with aluminum spool and handle, and jeweled bearings. The action is remarkably free: ten or twelve grains will overeme the inertia of the spool.

The " Henshall" quarlruple-multiplying reel mate by the T. H. Chulh, Rod Company, Post Mills, Vermont, is an improvement on the IIenshall-Van Intwerp reel deseribed in the first edition of this hook. As now made it is lighter, with jeweled hearings and an adjustalle click on the back plate. It is marle of German silver, and with its improved features is second to no other reel for noiseless, free and sustained action. It is well-made throughout and fully justifies all that is claimed for it by its makers. It will not disappoint the most exacting angler.

Several manufacturers have introduced "take-down" or "take-apart" reels which can be readily taken apart without the aid of a screw-driver, a feature that will be appreciated by the angler. 

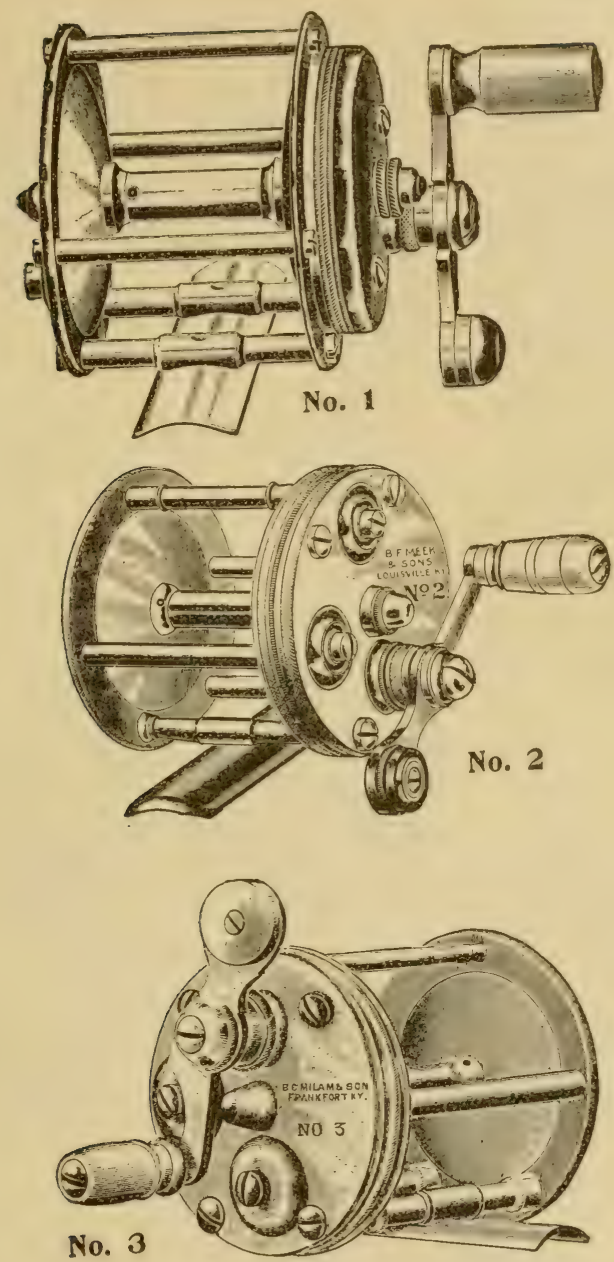

No. 1. Henshall Reel.-(T. H. Chubb Rod Co.)

No. 2. Meek Reel.-(B. F. Meek \& Sons.)

No. 3. Milam Reel.-(B. C. Milam \& Son.) 
I believe the first reel of this kind was the "President,"

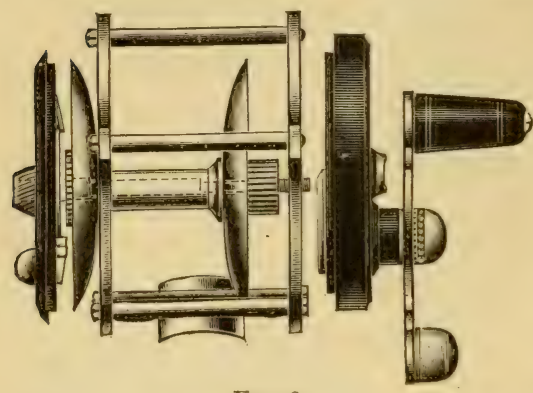

Fig. 6. made by Julius vom Hofe, which can be taken apart by loosening a thumb-screw in the center of the back plate and the working parts readily exposed for cleaning or oiling. This fine multiplying reel is made of German silver and hard rublere with adjustable click on the back plate, which can be operated when the reel is in motion.

The "Meisselbach" quadruple multiplying reel can be taken apart hy unserewing the metal hand from the rubber cap of the front plate, whereby the spool is removed. As the large cogwheel is very securely bridged in the eap, and the pinion cut on the spool-shaft, there are no

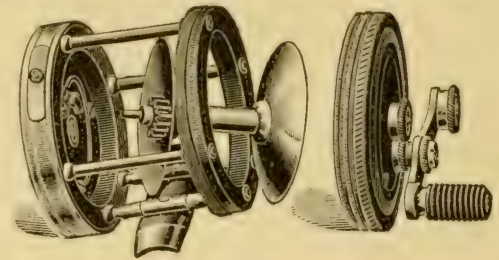

Fir. 7 . parts to eome loose when the reel is taken apart. A thumbscrew in the center of the back plate operates a new device whereby any degree of friction can be exerted on the spool, a feature of decided merit to one who can not "thumb" the reel in casting. It has a new and novel click, operated hy a slicte on the rim of the back plate, directly under the thumb of the angler; it operates only when the line is being pulled off, and is silent when it is reeled in. 


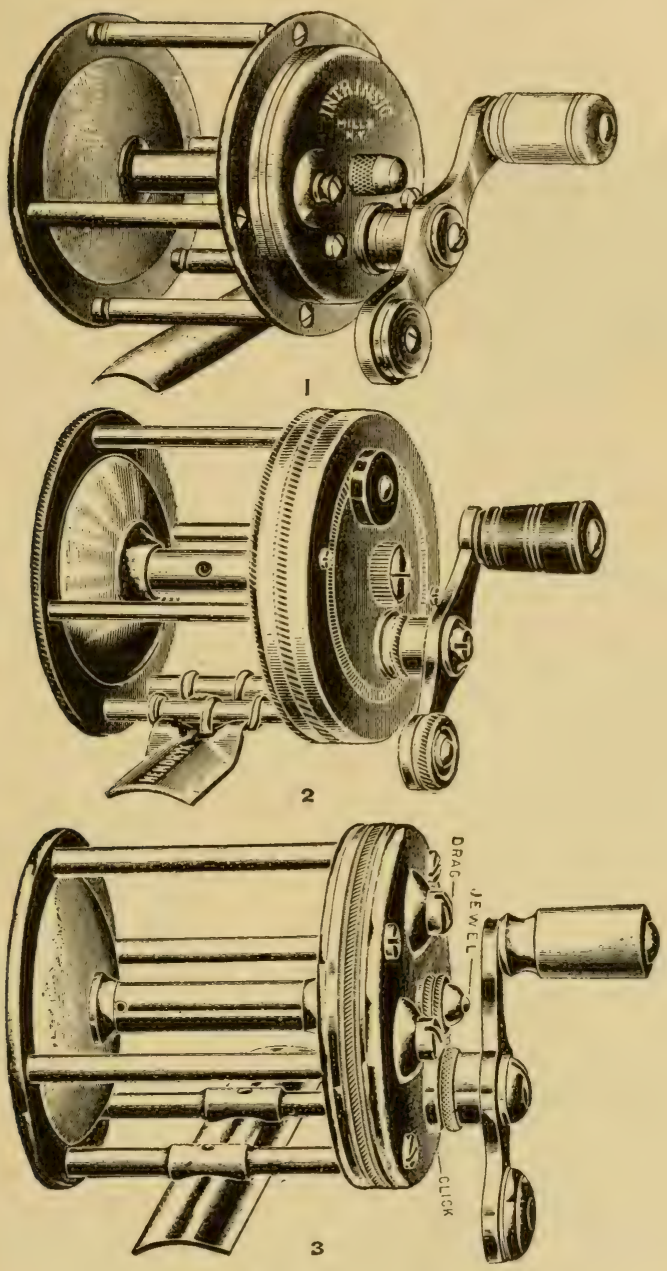

1. Quadruple Multiplying Reel-_(Wm. Mills \& Son.)

2. Quadruple Multiplying Reel. - (The Andrew B. Hendrix Co.)

3. Quadruple Iultiplying Reel.- (Dame, Stoddard \& Co.) 
The take-apart reel of the America Company has several new features at once original and meritorious. The front

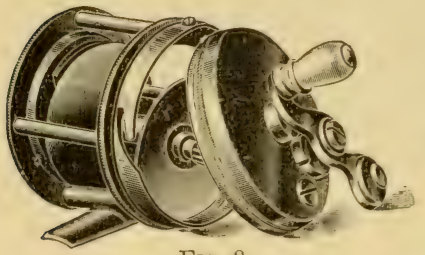

FIG. 8.

plate has three pins fitting into three slots on the frame of the reel, so that a short turn to the left releases the front plate. with gearing anel handle. When assembled it is secured by a spring button on the rim. The cog-wheel is bridged to the plate, and the pinion firmly affixed to the spool-shaft. I remarkable foature of this rees is that it is hall-hearing throughout. I strolie on the handle will cause the spool to revolve alonut a minute, the friction being reduexl, to a minimum. It is marle of a beantiful metalsatin-nickel, and an extra spool of German silver goes with each reesl, on which an extra line eam loe carried to replace the one in the reed in calse of a lad smat of the line from over running.

Other fine multi-

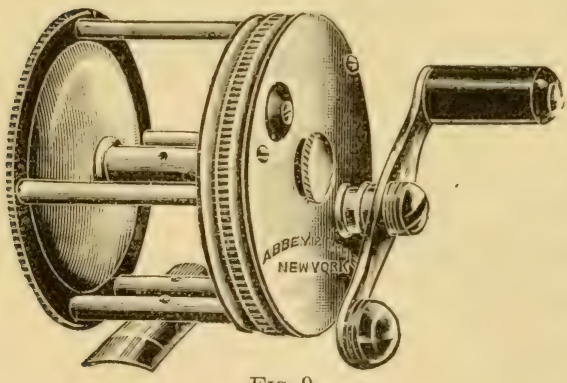
plying reels in which a free-running action in casting is held to be the paramount feature, in addition to being thoroughly wellmade of the best material, are the "Intrinsic" of Wil- 
liam Mills \& Son, the "Imbrie" of Abbey \& Imbrie, and the "Silver King" of Thos. J. Conroy, all of New York. These fine reels are all so well-known, and have been held in such high esteem for many year's by the angling fraternity, that further mention of their merits seems needless.

Another new feature of late years is a device for

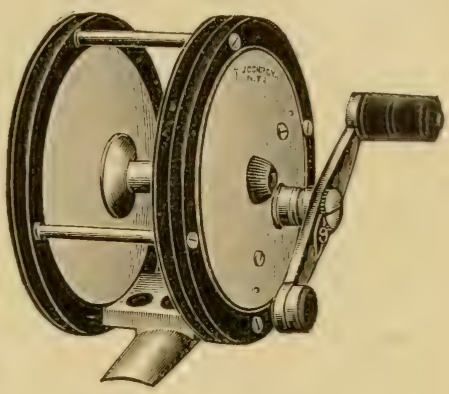

FIG. 10. level winding of the line, when reeling it, in order to prerent its bunching on the spool. For those anglers who seem incapable of guiding the line on the spool with the finger or thumb, this device is, indeed, a welcome one. The first reel with this device was made by Wheeler \& McGregor, Milwaukee, Wisconsin. A trav-

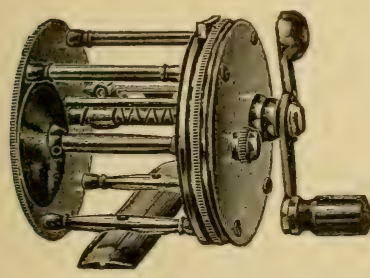

Fig. 11. eler carries the line back and forth when being reeled, winding it on the spool in level layers, in much the same way as sewing cotton is wound on the spool. Since the reel was first made it has been improved by having a steel screw-shaft in place of bronze, a hardened steel evelet on the traveler, and a better protector for the traveler guide. In casting there seems to be but little more friction engendered with this reel than one without the spooling derice; in other words as long a cast can be made, as less pressure with the thumb is required. 
A device to accomplish the same end is made by A. W. Bishop \& Son, Racine, Milwaukee, which they term an "independent automatic spooling device," which can be easily applied to an ordinary reel that has three-sixteenths of an inch between the hub band and the oil cap on the front plate. The device is made in three sizes to fit reels of corresponding lengths between the reel plates. It is operated by

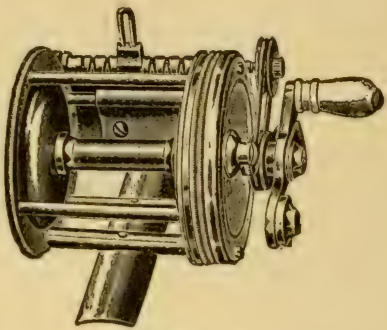

FIG. 12. two pullers connected hy a rubber hand. one pulley being attached to the handle of the reel by an ingenious clip. It works well if it fits the reel, and the same remarks concerning casting, with the reel previously mentioned, will apply in a measure to a reel fitted with this device.

Still another device to aid the angler, who

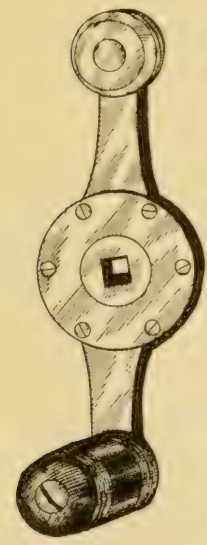
needs such assistance, is the drag handle, which creates friction enough to prevent the fish from taking line too fast; it substitutes the thumb of the angler when placed on the spool to accomplish the same purpose. A. B. Meisselbach \& Brother make "The Governor," a friction device placed inside a balance handle, which may be fitted to any reel, by replacing the original handle. It can be adjusted to any amount of friction desired by the turning of the small screws on its disk. When playing a fish the angler holds the handle between his fingers, and when the fish ceases to pull he can reel it in in the usual way. 
Another device for the same purpose is the "Gem" drag handle furnished by Malcolm A. Shipley, which operates in the same way as just described, though constructed on a different principle. The friction device consists of a thumb-screw containing a strong spiral spring, by which the desired amount of friction is exerted by simply turning the thumb-screw. Both of the devices mentioned operate by drawing the shaft of the spool against the handle.

The following account of the history of the Kentucky Reel was confributed by me to the "Outing" Magazine, for December, 1900 ; it is reproduced here as a matter of record, no one else now living being in possession of the data :

\section{Evolution of the “Kentucky Reel."*}

The multiplying fishing reel originated in Kentucky albout the beginning of the Nineteenth Century. It has been asserted that it was first made in England. but I have been unable to find any reference to it, even in the oldest

*As Assistant Chief of the Fisheries Department of the World's Columbian Exposition, at Chicago, in 1893, I had charge of the Angling Building, and, among other exhibits, I had a collection of "Kentucky reels," embracing those of Snyder, the Meeks, Hardman, Milam. Sage, and others. It showed the evolution of the reel from the old-fashioned, home-made wooden spool, mounted by the local tinsmith, to the fine productions of the present time. This article is based on that collection. The pen-drawings of the oldest reels are by $\mathrm{Mr}$. Charles Bradford Hudson, except several by myself. 
British works on angling. It certainly has not been used there within my recollection. For a century the British angler has used the single-action reel for all branches of fishing.

James Lane Allen has shown that the good people of the blue-grass region of Kentucky exhibit many of the distinctive traits and customs of their English and ScotchIrish ancestors; but in no feature is this heredity more pronounced than in their love for angling. With them, angling is the outward manifestation and practice of an inherent and inherited attribute. and is in no sense a fad or hobby.

Black-bass fishing, as an art. had its origin on the historic soil of Old Kentucky, in that particular portion known as " Goll's own country" - the blue-grass section. It was especially the counties of Fayette. Bourbon. Woodford. Seott and IJarrison that were renowned for their skilled angler's. who fished the then famous streams of the Kentucky River. its tributary, the Eilkhorn, and the Licking, Stoner and other adjacent waters.

At that time the Kentucky River was a free-flowing stream. without dams between Frankfort and its mouth. It alounded in black hass. pike-perch (called "salmon"), pike and oceasionally a mascalonge. I have seen heads of the three last-named species from the Kentucky, Ohio and Tennessee rivers. preserved as trophice by old-time anglers, from fish which must have weighed almost forty pounds.

IIost of these nnglers were among the best and brightest and most intelligent and cultivated men of that period, who adorned the several professions or were the lordly proprietors of rast domains of perennial green. Among others may he mentioned the well-known Kentucky family names of Clay, Bedford. Hume. Brown, Morris, Bibb, 
Bacon, Holman, McCurdy, Mills, Ennis, Harrey, Blair, Crittenden, etc.

The rods used by these pioneers of bass fishing consisted of the upper ten feet of a well-seasoned, light and straight native cane reed, weighing from four to six ounces when complete with guides and tip. The reel was lashert or seized to the butt of the rod, the reel-plate having holes in the ends for this purpose, as may be seen in some of the illustrations following. The line was that known as "sea-grass," though really raw silk, and the size the smallest made, or No. 1 . It will be seen from this that the tools and tackle were as light, if not so suitable or elegant, as those of the present day.

Mr. J. L. Sage, of Lexington, Ky., a reteran angler, who is still making "Kentucky reels," presented me with a click reel, and showed me his fly-rod and flies, all made and used by him as long ago as 1848; so that fly-fishing for black bass mas practiced as early in Kentucky as in any other section of the country.

At a rery much earlier day. about 1810 , there existed the Bourbon County Angling Cluth, of which George Snyder, of Paris, Ky., was the president; and he it was who made the first "Kentucky reel," which has since become so famous, and in my opinion the first multiplying reel in the world. Previous to this time the black-bass angler was compelled to use the old single-action reel, usually of English make, or the dis-

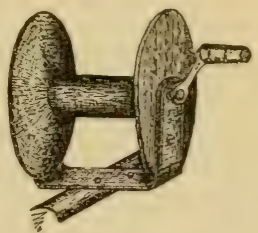

Fig. 13. Old Woulen Spool. carded spool from his wife's work-basket, when of large size, and mounted on a frame by the local tinsmith.

Fig. 13.- Black wooden spool mounted on iron frame. Disk, 19 inches diameter: 13 inches between disks: flat iron crank with liack woolen handle; holes in ends of reel-plate for seizing to rod. 
To this day the octogenarian angler in Kentucky calls his reel a spool. Mr. Sage informed me that he had seen the spool used on the Cape Fear River, near Wilmington N. C., in 1839 and 1840 .

George Snyder was born in the same county as Daniel Boone - Buckis, Pa. He went to Paris, Ky., then called Hopewell, about 1803, and died there on February 10, $18 \pm 1$, aged sixty years. If was a skillful watchmaker and silrersmith; being a good practical angler, and seeing the necessity for a rapid multiplying reel for blackbass fishing with the live minnow, he proceeded to invent one. Snycler's first reel was made for his own use, about 1810. He afterward made reels for members of his club, and others.

Some twenty years ago the late David M. Snyder, of Cynthiana, Ky.- the last surviving son of Ceorge Sny-

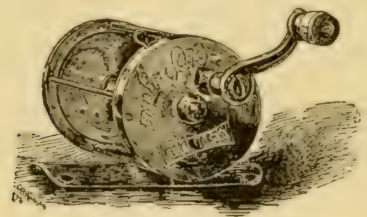

Frg. 14

G. Snyder's Own Reel.

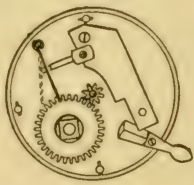

FIG. 15.

G. Snyder's Own Reel Gearing.

der-showed me a reel made by his father, in which the ends of the spool-shaft were beveled to points which fitted into hereled recesses of pivots that screwed into the center caps of the outer disk-plates of the reel. By this compensating derice any wear eould be readily taken up, or the

Fig. 14.-George Snyder's own reel, made of brass, in 1810. Disk-plates, $13 / 8$ inches diameter; length of spool, $13 / 8$ inches. Marked in script "G. Snyder" and stamped "G. S." The shaft rums on garnet jewels. This reel is in the possession of his grandson, R. J. Snyder, of Louisville, Ky.

Fig. 15.-C George Snyder's own reel gearing. Brass lock spring, silver alarm spring. 
running of the reel regulated by a turn of these screw pirots.

It will be noticed, perhaps, that all of the Snyder reels figured are quite narrow in diameter of the spool, and also much longer than in those of the present day. This is in sccortance with the fact that a long, narrow spool runs

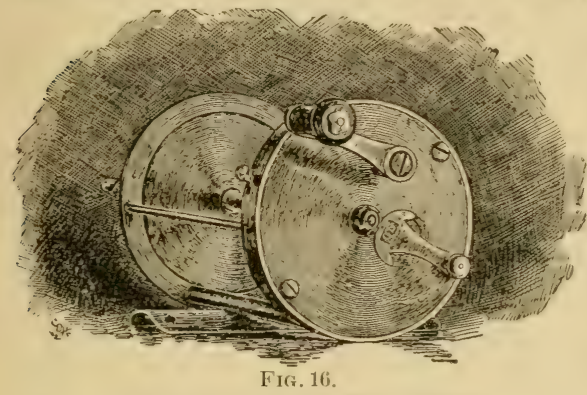

Large Snyder Reel, Front View. more rapidly, all things being equal, than where the spool is short and of greater diameter. I have seen but one Snyder reel of large size, which was no doubt employed for large fish, as ma-calonge, pike and the so-called "salmon" (pilie-perch or wall-eyed pilie). This reel is shown in

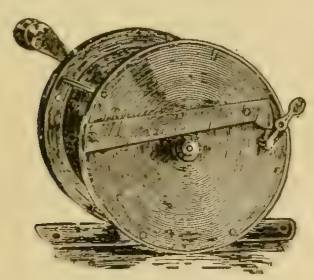

Fis. $1 \%$.

Large Snyder Reel, Back View.

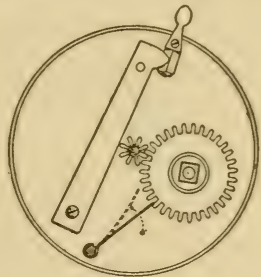

FIG. 18.

Large Snyder Reel Gearing.

the illustrations. Its peculiarities are a curiously-shaped flat lever. for operating the alarm spring by means of a

Fig. 16.- Prass reel made by Geo. Snyder about 18:0. Diskplates, $23 / 8$ inches diameter; length of spool, $23 / 8$ inches.

Fig. 17.- Showing back disk-plate with drag-spring outside.

Fig. 18.- Showing gearing. Steel wheel with 32 leaves; steel pinion with 8 teeth, a quadruple multiplier. 
pin working in a curved slot, and the flat brass dragspring, which is on the outside of the back disk-plate. I imagine it was placed there to allow of its being used while the reel was ruming. which would prove quite an adrantage while playing a large fish. This reel is in the possession of Mr. R. J. Snycter. of Louisrille, Kr., who sars it is one of the oldest recls mate by his grandfather.

A very interesting reel is one made by George Snyder, in 1S21, for IInn. Brutus J. ('lar, who was a member of Congress in 18fit. It is now owned by his son, Mr. C. F. Clay, of Bourlon Countr, Ky. and is still in good condition, though it has been used by Mr. Clay and his father for nearly serenty years. It is marked in script. "G. S.,

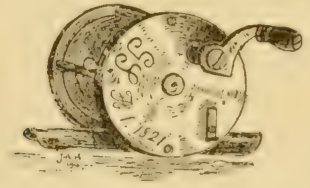

FIG. 19.

Clay's Snyder Reel,

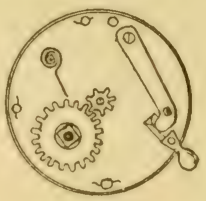

FIG. 20 .

Clay's Snyder Reel Gearing.

Feh. 1, 1s:1." 'This. like most of (ienrece snyder's reels, has the stedel culs of the spool-shaft projecting through holes in the center of the disk-plate. Also, as in all of Snyter's reels. the pillars are riveterl to the back plate, and project thromeh the inner front plate, where they are secured by wire keys.

Another rese marle by Genge Snycter, not later than 18.5, is reproducert to show a peculiar feature, one that I have nerer seem hefore mer sinee in a "Tientucky reel,"

Fig. 19.- Reel made by George Snyder in 1821; brass, in good condition; $1 \frac{1}{2}$ inches in diameter; length, $1 \frac{1}{2}$ inches.

Fig. 20.-Gearing. Brass wheel with 21 leaves; steel pinion with 7 teeth; triple multiplier. 
and that is the absence of both drag and alarm. There is nothing but the lock-stop, whereby a pin in the flat brass spring drops into a hole in the spool-disk. I cannot conceive how a Kentucky angler of the olden time could be

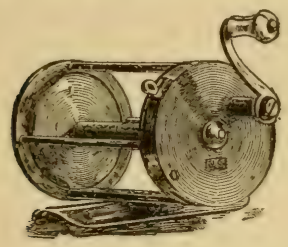

Fig. 21.

Snyder Reel.

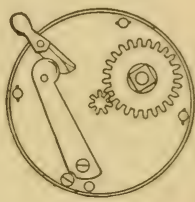

Fig. 22.

Snyder Reel Gearing.

content to fish without an alarm spring to his reel! I am free to say, however, that of all of Snyder's reels which I have seen I prefer this one. for, personally, I have no use for either drag, click, alarm or lock in a multiplying reel.

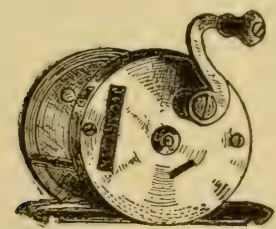

Fig. 23.

J. \& C. Snyder Reel.

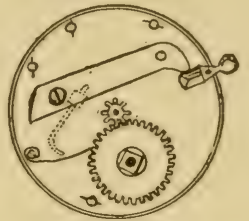

FIG. 24.

Massie's Reel Gearing.

Fig. 21. - This reel was made sometime between 1815 and 18:2.2. It is of brass, like all of Snyder's reels. It is in excellent condition to-day. Diameter, $15 / 8$ inches; length, $1 \frac{1}{2}$ inches.

Fig. 22.- Gearing. Brass wheel with 24 leares; multiplies $3 \frac{1}{2}$ times.

Fig. 23.- Brass reel stamped "J. \& C. Snyder." Diameter, 13/4 inches; length of spool, $1 \% / 8$ inches; multiplies four times.

Fig. 24.- Gearing of brass reel made by Charles Snyder for present owner, Mr. Wr. W. Massie. Diameter, $21 \frac{1}{8}$ inches: between disks, $25 / 16$ inches. Alarm is operated by a bent arm of steel wire, which is moved by a small block attached to an outside oblong slide. 
After Snyder's death two of his sons, John and Charles Snyder, succeeded to his business, and they made a few reels. One is now in my possession, and I have seen but one other, owned by Mr. Wr. Wr. Massie, of Paris, Ky. The latter is stamper "G. S.," but was made by Charles snyder expressly lor Mr. Massie, who saw him at various times at work on it. Both reels were made between $18+1$ and $18+4$.

The next perion to turn his attention to reel making. after the alder Snycler, was Jonathan Fleming Meek, also a skilful watrhmaker. He went from Danville, Ky., to Frankfort, aloout 183.$)$. Where he mate his first reel for Hon. Mason Brown, of Frankfort, a noted jurist of his

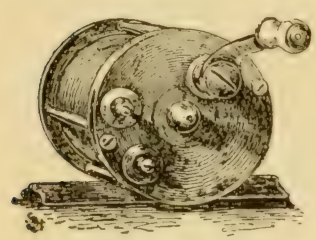

Fig. 25.

Higgins' J. F. Meek

Reel, Front View.

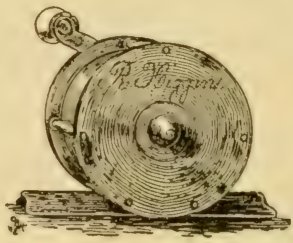

FIG. 26.

Higgins' J. F. Meek Reel, Back View.

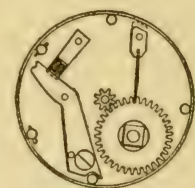

FI(r. : $:$.

Higgins' J. F. Meek Reel Gearing.

day, and a deroted angler. Judge Brown, having had his snveler red horrowed or stolen just at a time when the bass began to bite their best, prevaled on Mr. Meek to make him one.

At an early day there were quite a number of Kentuckians who owned plantations in Mississippi, Louisiana

Fig. 25.- Brass reel made by J. F. Meek about 1840. In fair condition, perfectly plain. Diameter, 15/8 inches: length, 13/4 inches.

Fig. 26. - Showing back disk-plate of No. 25.

Fig. 27.-Gearing. Steel wheel with 34 leaves; steel pinion with $\mathrm{S}$ teeth; multiplies a little more than four times. 
and Arkansas, but spent their summers in Rentucky. Two of the Meek reels shown were made for such parties. One for Mr. R. Higgins, of Lexington, a M[ississippi planter, the other for Mr. D. Vertner, a Louisiana planter. The latter reel is now in the possession of his granddaughter, Mrs. Alexander Jeffrey, of Lexington, Ky.

These reels, it will be observed, are improvements in some respects on the Snyder reels. There is a collar around the crank-shaft; the ends of the spool-shaft do not project, and the alarm and drag-springs are operated by sliding buttons, as in the modern reel.

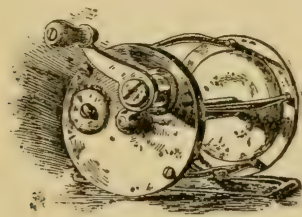

Fig. 28.

Vertner's J. F. Meek Reel, Front View.

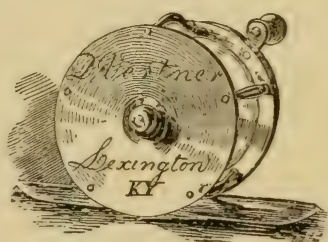

Fig. 29.

Vertner's J. F. Meek Reel, Back View.

It seems that about the time that Jonathan F. Mreek made his first reel, in 1833, or soon after, at least one reel was made by Theodore Noel, also a watchmaker of Frankfort.

J. F. Meek continued to make recls until about $18 \pm 0$. when he formed a partnership with his brother, Benjamin F. Meek, who was likewise a fine watchmaker. After this the reels were made by B. F. Meek, and stamped "J. F. \& B. F. Meek."

Fig. 28.- Solid silver reel made by J. F. Meek about 1840. In good contition. Diameter. 11/2 inches: length, 1 15/10 inches.

Fig. 29.-Back disk-plate of Yo. 28. Gearing about same as No. 27. The pillars are made arching instead of straight. 
About the year $18+3$ a very fine workman and expert watchmaker, of I.ouisille, Ky., named J. IV. Hardman, legan making multiplying rcels for black-bass fishing. IIis recls were a great improrement on those previously made by others. He shortened the spool and increased the diameter, aflixed the pillars to the disk-plates by serews instead of riveting, added some ormamentation, and al-

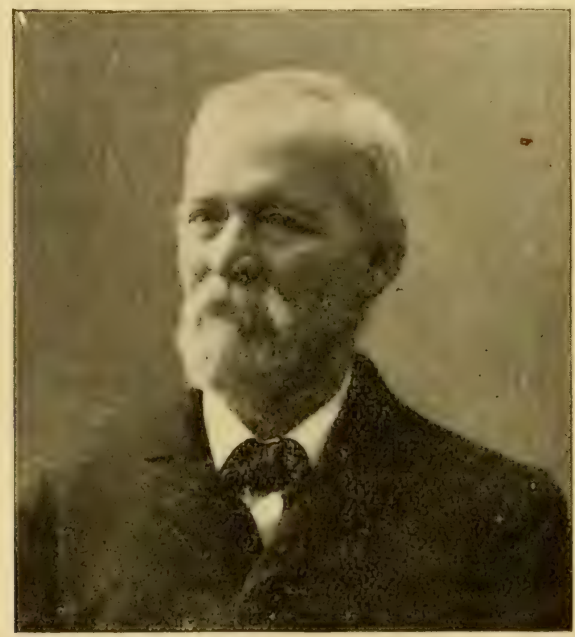

Fig. 30.

Mr. Benjamin F. Mreek.

together made the first true and substantial improvements in the "Kentucky recl," both as to its practicability and alpearance. and these were followed thereafter by all other makers. The "Kentucky reel" to-day bears testimony to his ummistakable genius and fine handiwork. The Hardman recl illustrated is the property of Mr. J. F. Speed, of Louisrille. Kr.. and is in excellent condition. It was made about 18.5 , and is a very handsome piece of work. of Crerman silver. The sliding buttons are gold-plated, as 
are the screws. The ornamentation is very fine and workmanlike.

Mr. Benjamin C. Milam, whose name is almost synonymous with the "Kentucky reel," went to Frankfort, Ky.,

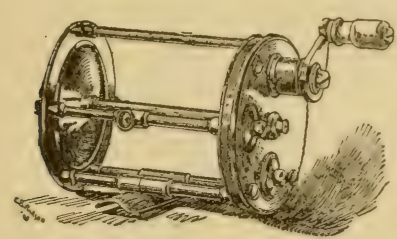

FIG. 3i.

Hardman Reel.

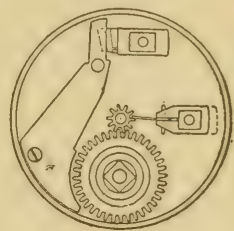

Frg. 32,

Hardman Reel Gearing.

in 1835, and worked awhile with Beverly Noel, a watchmaker, a brother to Theorlore Noul, previous ly mentioned. He visited Paris, Ky., in 1836, and saw George Snyder

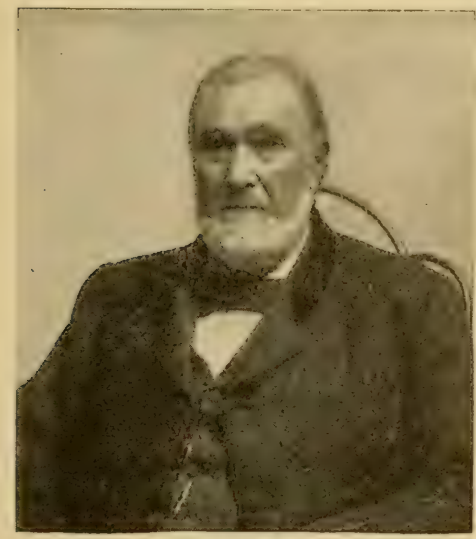

FIG. 33.

Mr. Benjamin C. Milam. and his reels. In this same year he engaged as an apprentice to $\mathrm{J}$. F. Meek, and it was not long before the reel making was given over to him and B. F. Meek, when the latter came into the firm.

The Meek brothers dissolved partnership about 1851, Jonathan going to Louisville, but returning again to Frankfort just before his death in 1884 . After the withdrawal of

Fig.' 31.-German silver reel made by J. W. Hardman. Diameter, 2 1/16 inches; length, 2 inches.

Fig. 32.-Gearing of No. 31. Pinion has 10 cogs; wheel, 40; quadruple multiplier. 
J. F. Meek, the firm became Meek \& Milam, which in turn was dissolved at the end of five years, though the former partners continued to occupy the same store, Milam deroting himself to making reels, while B. F. Meek took the watchmaking and jewelry business. All reels made by Mr. Milam continued to be stamped "Meek \& Milam" until 18r8, when he used his own stamp of "B. C. Milam." In later years, having trained his son to the trade, he took him into his business under the firm name of B. C. Milam \& Son, which is continued to the present time.

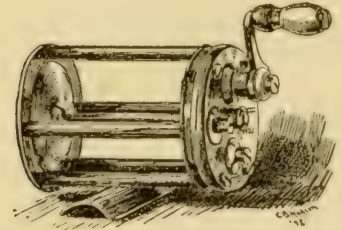

FIG. 34.

Meek \& Milam Reel.

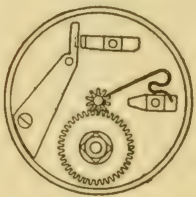

FIG. 35.

Meek \& Milam Reel Gearing.

There were a fow reels with so-called " "entrilugal gearing" made at an early date by B. F. Meck, a Mr. Barbour, of Georgetown, Kr.. and T. C. Milam. Among the reels T exhibited at the ('hicano World's Fair was a rery elaborate and ormamental one of solid silver, marle by B. F. Meek, about 1S16, for an artist of New Orleans, T. S. Mayeau. A novel frature of this reel was the "bell-click," made upon the same principle as the repeating watch,

Fig. 34.- Brass reel made by B. C. Milam and stamped " Meek \& Milam No. 1." In excellent condition. Diameter, 13/4 inches: length, $15 / 16$ inches.

Fig. 35.- Gearing is essentially as made to-day. Pinion has 10 teeth; cog-wheel, 40 ; quadruple multiplier. 
whereby the artist-angler could really enjoy the "music of the reel," the two bells being tuned in thirds.

The peculiar mechanism of the reel is the application of the principle of the epicycloidal wheel, wherely reciprocating motion is converted into circular motion. While the power of this plan of gearing is greater than in the ordinary reel with two wheels, the friction is also too great for casting; consequently it was abandoned.

An old reel stamped "Mcek \& Milam" was exhibited in $m y$ collection, made somewhere about $18+4$, and is shown in the accompanying illustrations. The pillars

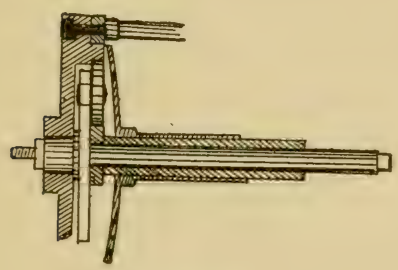

FIG. 36.

Diagram of epicycloidal wheel.

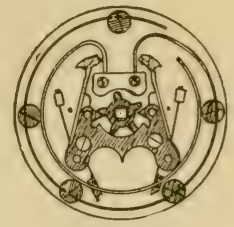

FIG. 37.

Bell Click.

are still of the Snvder plan, as also the long narrow spool. The improvements are a collar to crank-shaft. sliding buttons for alarm and drag, and a better shape to front diskplate. Here we have for the first time the bent or U-shaped alarm spring formed of a piece of wateh spring. It will be further elserved that with the exeeption of the ornamental bars or pillars of the Hardman reel, this reel is a close imitation of it in its general form, in the sliding buttons and their screws. in the collar and the retaining screw of the crank. A strong resemblance is also seen

Fig. 36.- Gearing of epicycloidal wheel.

Fig. 37.- Bell click, showing bells and hammers. 
in the gearing, more especially in the sliding blocks and drag-spring.

M. J. L. Sage, of Lexington, Ky., but previously of Frankfort, was alio an early maker of thr "Kentucky reel," and I am satisfect that he was the first to make a

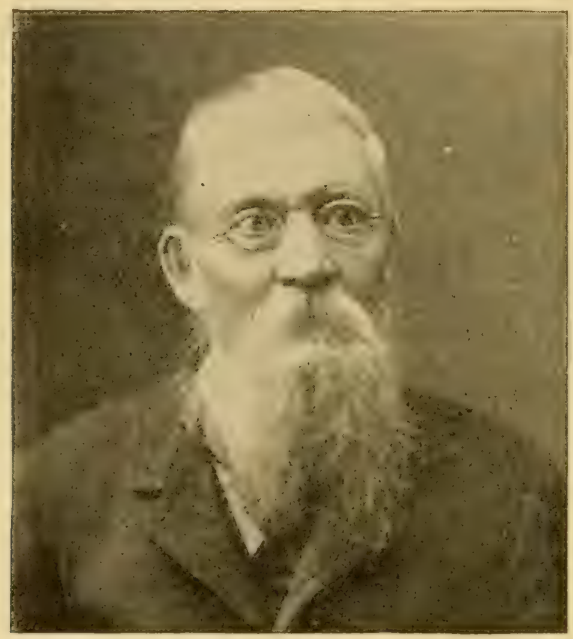

Fig. 3S.

Mr. J. L. Sage.

click reel, in Kentucki, for black-bass fly-fishing. of which branch of angling he was one of the pioneers. I have the smallest and neatest "Kentucky reel" I have ever seen; it was made by Mr. Sage.

In 1883, Mr. B. F. Mrek went to Louisville, Ky., where he entered on a new eral of reel making. He formed a partnership with his two sons. He made a new departure in the gearing of the recl, which he called the "spiral 
gear." This consists in cutting the teeth of the wheel and pinion obliquely or diagonally, instead of horizontally. The space between the teeth, at their base, is also cut rounding, instead of flat or square.

Other makers of the "Kentucky reel" are Geo. W. Gayle, of Frankfort, and James Deally, of Louisville. The reel as now made is still principally for black bass fishing, though larger sizes are furnished for striped bass and tarpon.

In connection with the foregoing account I wish to add that before Snyder's day, the black bass anglers of Tentucky used the single action reel, and sometimes a wooden thread-spool mounted on a brass or iron frame as mentioned. Many years ago a gentleman named Lewis owned an estate called "Llangollen." a few miles from Frankfort, Kentucky, on the banks of the classic Elkhorn, then a famous black bass stream. He was a sportsman of the old school and a frequent contributor to Skinner's "American Turf Register and Sporting Magazine," and later of Porter's "Spirit of the Times." He was the owner of an old spool similar to the one figured which he left in 1842 with Mr. Sage for repairs, and said that he hrought it from his old home at Wytheville, Virginia, and had used it for many years. He preferred it to the multiplying reels then being made in Kentucky, and used it for bait-fishing, as well as for fly-fishing.- a striking illustration of that prejudice, called by courtesy conserratism, of the British angler, for he was no doubt of Welsh extraction judging from his name and the title of his estate. The old spool figured may be the one alluded to, as it came from the archives of Mr. J. L. Sage, an oId Ken- 
tucky reel maker, who has recently joined the great majority across the silent river.

As an interesting relic the gaff-hook used by George Snyder in comnection with the large reel described, is here figured. It is in possession of his grandson, and was doubtless emplored to gaff the immense pike-perch, pike and mascalonge that were found in the Kentucky River at an early day. It is about six inches in length and nearly two inches across the bend.

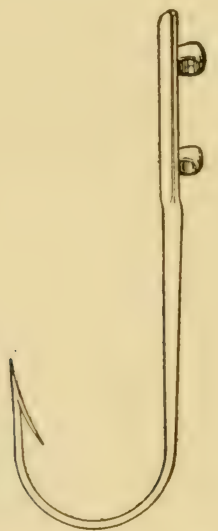

George Snyder"s Gaff-Hook. 


\section{CHAPTER XI.}

\section{FISHING LINES.}

"I will lose no time, but give you a little direction how to make and order your lines, and to color the hair of which you make your lines, for that is very needful to be known of an angler." IZAAK WALTON.

\section{Refi Imanes for Casting the Minnow.}

A BAIt line for casting a minnow should, in the first place, be composed of the rery best material, which, in this case, is raw silk. It should be of very small caliber, the smallest that can be made consistent with strength, and

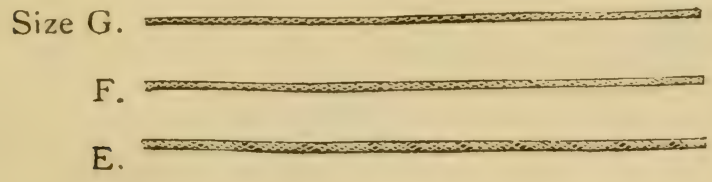

raw silk fulfills this condition ketter than any other material. It should be very hard, compact, and closely braided. These conditions secure a line that renders freely and easily, is quite elastic, and at the same time absorbs but little water, and will not kink or snarl in casting. The line should, moreover, be tinted some suitable color, to render it as nearly invisible as possible, for it must be remembered that we cannot use a gut leader in casting the minnow.

The best line, then, we will say, is the braided, or plaited raw silk line, of the smallest caliber, for ordinary fishing; but where the bass arerage fully three pounds, the next largest size may be used, though I would adrise the smaller 
line even here to be employed in preferenec. Raw silk lines require the greatest care to preserve their usefulness. They should be carefully dried after use, as soon thereafter as possible, for witherit this caution they soon become weak and rotten. And, moreover, a reel-line, for bait-fishing, should never be waterproofed with any preparation that increases its caliber or decreases its pliability, for this can only be done with great detriment to the line, as regards casting.

Next best to the raw silk line is the braided boiled silk line, or. as sometimes called, the dressed silk line. This is a good line when plaiterl hard and closely, but most of them are ton loosely braided, in which case they alsorl, water quite freely, which derelops an annoying propensity

\section{3.}

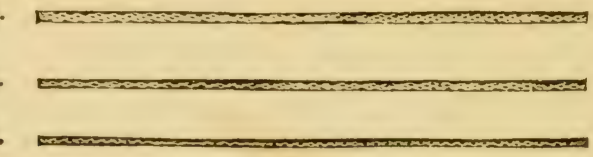

of clinging to the rod in casting, and interferes somewhat with the free rendering of the line. They are made of good stock, however, and are quite strong, and nicely tinted. The boiled silk line should be as well cared for, and as carefully dried, after use, as the raw silk line, and for the same reasons.

The braided linen line is a very good one, in one respect better than the silk. being quite hard and closely plaited, but the caliber is too large. The smallest size now made is too great for a recl-line for black bass bait-fishing. Where the hass run very large, however, as in lake fishing, or in the extreme south, the smallest size may be employed with satisfaction. It will last longer than the silk line, 
and will bear rougher and more careless usage. It is much hearier, however, is not so elastic, and, therefore, not so desirable a line, in these respects, as the silk line. The only size to use is $\mathrm{G}$, or 5 .

The above are the only lines that I can recommend for bait-fishing for black bass, where much casting is practiced, for braided lines are the on!y lines that will not kink and curl. No twisted or cable-laid line can be profitably employed for this purpose, on account of this kinking propensity, which, to the angler, is a source of great troulle, rexation, and perplexity; and there is no method by which the kink can be entirely remored or eradicated from twisted lines. Some anglers maintain that this kinking quality can be taken out of a line by trailing it in the water behind a boat, without sinker or hook; but this is a delusion and a smare, for after casting a line a few times in succession that has been treated in this manner for hours, it will kink and snarl as harlly as erer, and this is to be naturally expected, from the mode of manufacturing such lines. It is unreasonalble, moreover, to expect a twisted line to perform the functions of a braided one, for this it can not do.

In the first edition of this book I made the statement that the perfect line for black bass bait-fishing was ret in the future. and suggested how a much better line than any in use could be made. and expressed the hope that such a line would soon be produced, as I had invited the attention of the extensire fishing line manufacturing concern of the Henry Hall, Jr., Company, of Mighland Mills, N. Y., to the matter.

I am glad to state that suitable lines were shortly afterward manufactured by the said company, in response to those suggestions, and hare been in the market for many 
years. These lines seem to be all that can be desired as reel-lines in bait-fishing, for which the bass fisher is to be congratulated.

The lines just alluded to are styled letter " H," or No. 6 in size; and while they are a third less in caliber than the "G," or No. 5 line, they seem to contain the same amount of stock, and to be fully as strong, but being more closely braided they are much smaller in size, and more compact. They absorl, but little water, and consequently render very freely in casting the mimnow. Owing to the demand created for the " $\mathrm{H}$ " line, other manufacturers soon began making them.

They can now be had in several styles, and of the best selected dressed and raw silk. The dressed or

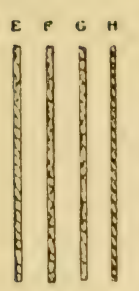

boiled silk line is very firm and light, weighing not quite two grains to the yard - one hundred yards weighing one hundred and eighty-five grains. It is of the same caliber as the No. 1 sea-grass line, and fully as strong, sustaining a strain of eight pounds.

The raw silk line is very hard and compact, and a trifle heavier than the boiled silk line, weighing about two and one-third grains to the yard, or two hundred and thirty-fire grains to a hundred yards. It is mottled in color. like most raw silk lines. It sustains a dead weight of tron pounds, which is at least three times the strength actually required with a pliant rod. I have often killed bass areraging three pounds with a line that would not sustain more than a pound, dead weight.

This line is also made waterproof by a new process. which does not detract in any way from its nse as a bait line, as the waterproofing does not diminish its flexibility or snftness in any degren - a result that had before been 
impossible to obtain, as all waterproof lines were too stiff and unyielding for minnow-casting.

The process of waterproofing, however, makes the line perfectly black in color, which at first sight might be deemed an objection by some. But I have experimented with it in numerous practical tests, alternating with lines of lighter tints, and have never discovered that it made the slightest difference to the fish. And if we will reflect a moment, and hark back to our youthful experience in angling, when we fished for fingerling trout, shiners, gudgeons, or sunfish, with black sewing silk for lines, or in our adolescent days, when we marle our own lines for black bass fishing, by twisting together two or three strands of sewing silk - we somehow always preferred black silk and we were just as successful in luring the wily bass with those somber, home-made lines, as we were after the braided, light-tinted lines came into vogue.

Mr. Malcolm A. Shipley, Philadelphia, furnishes a black line of this character, size $\mathrm{H}$, which is closely-braided, waterproof, and very strong, while being soft and pliable.

Messrs. Abbey \& Imbrie, New Tork, furnish a size G line of Italian silk, closely-braided, of a mottled tint of black and red, a remarkably strong line, and quite pliable. Their No. 90 organzine sericum braided line is very strong, being tested to fourteen pounds, though about $\mathrm{H}$ in size; its color is black.

Messrs. William Mills \& Son, New York, furnish a drab, waterproof, hard-braided silk line, which they style the "Record." It is made in three sizes for minnow casting, G, H, and a still smaller size for tournament work. The best caliber for the angler is $\mathrm{H}$, though I prefer the tournament line for my own use.

I have thoroughly tried the lines mentioned above, and 
can recommend their use for strength, pliability and all the necessary features that are essential in a minnow-casting line.

\section{Reel-Lines for Fly-Fishing.}

The reel-line for fly-fishing must necessarily be heavier than the line used in bait-fishing, the greater weight of the former heing required to cast objects so light and delicate as artificial flies; while in the case of the small and light bait-line, the mimnow, swivel and sinker give the
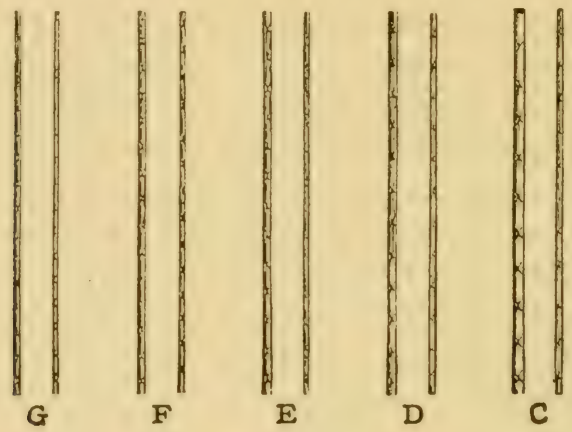

requirel woight for casting. Increased weight is obtained by increase of the caliber of the line, so a fly-line is consequently of a larger size than a bait-line.

In days long gone the twisted or plaited hair, and hair and silk. lines were employed altogether by the best anglers for fly-lines, but they have been entirely superseded by the really elegant tapered and enameled waterproof braided silk line. The latter is the line par excellence for all kinds of fly-fishing. being smooth. round, polished and perfectly waterproof. and is just stiff and heary enough to favor a perfectly straight cast. without looping or kinking, qualities that are peculiarly essential to this mode of angling. 
Those reterans who have used the old-fashioned fly-lines, are prepared to speak feelingly and appreciatively concerning the great superiority and excellence of this line.

They are made in sereral sizes for salmon, black bass and trout fishing; are very strong and serviceable, and, for black bass angling, can be purchased in lengths of from twenty-five to thirty yards. They are usually fashioned with a regular and gradual taper for several yards to the fly-end, the fly-end being only about one-half the caliber of the reel-end. Some lines, and which is the best way, taper both ways from the middle. They are usually stained of a greenish-olive hue, which harmonizes well with the tints of the water, sky and foliage. From twentyfive to thirty yards is the right length, and the size should be either $\mathrm{F}$ or G, which corresponds with Nos. 4 and 5 , some dealers designating the sizes by letters, others by numerals.

Next best to the tapered enameled silk line is the oiled, braided silk line; though this is not tapered, it is a good, strong and useful line, and is used by many anglers in preference to all others. It is tinted of a similar shade to the enameled line, and altogether is a very satisfactory flyline, being heavy enough, and, withal, cheaper than the tapered line. Letters E and F, or Nos. 3 and 4, are suitable sizes.

Next in order is the braided linen line, either waterproof or plain. Where economy in price is the necessary object, this is the best line to select, though the angler should bear in mind that the best is the cheapest, for he knows full well that to no other class of goods does this maxim apply with more force than to fishing-tackle. This line is strong, firm and round, and is capable of long and hard service, if proper care is taken to dry it thoroughly 
always after using. It is well adapted for making a nice, straight cast, and will not curl or kink. It is usually stained a light shade of slate, or a grayish drab. Letter F, or No. 4 , is about the right size.

Some fly-fishers use the ordinary braided raw or boiled silk lines. which, while being the best lines for bait-fishing, are not so well adapted for fly-lines, on account of their light weight; the medium sizes, however, answer tolerably well. Letter E, or No. 3, is the correct size, when used for black bass fly-fishing.

All fishing lines that are not absolutely waterproof should be carefully dried after use; and even waterproof lines would be much benefited by

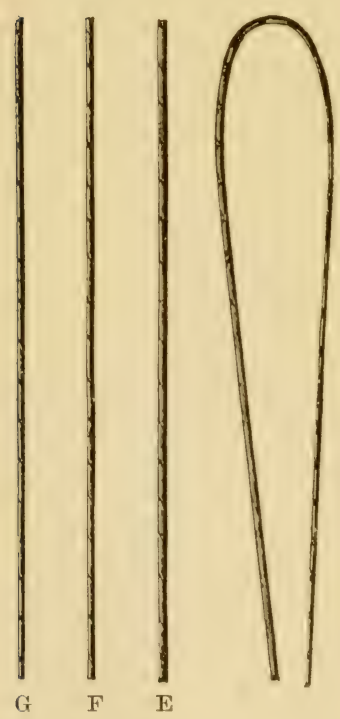
an airing before putting them away. Even the best lines become weak and worthless through a want of proper and judicious treatment. It is impossible to make a line that is indestructible, or proof against mildew or rot, though many anglers seem to think to the contrary, judging from the shiftless and reprehensible manner in which they use them; then, when the line fails, they blame the manufacturer.

Any reputable and responsible dealer can furnish good lines for fly-fishing, but among those I have used I can conscientiously mention the following:

The "Hereules" waterproof, enameled line furnished ly Mr. Thomas J. Conroy, New York, is one of much merit, 
being perfectly smooth, hard, evenly braided, and void of any tendency to stickiness, a quality that will be appreciated by those who have used inferior lines.

Abbey \& Imbrie, New York, offer a tapered fly-line, No. 57, which is simply unexcelled in every way. It embodies all the essential qualities of a fly-casting line, being smooth, strong, and of uniform excellence throughout.

When in England, I examined the best English fly-lines, but there was nothing that could compare to those of American manufacture. London dealers showed me, with much pride, the metal-center line, which they claimed to be the best fly-line in the world.

The advantage claimed for the metal-center line is that it can be used of a smaller caliber and still retain the same weight as a larger line; and at the same time it is probably a little stronger, though for that matter any of the enameled lines are strong enough.

The metal center consists of an extremely small copper wire, around which the line is braided. The wire is so fine that it does not stiffen the line to an appreciable degree, as might be imagined. As the line is so thoroughly waterproof, there is not much probability of the wire becoming oxidized or rusted.

\section{Rod-Lines.}

The twisted line has its proper place in fishing, and sometimes answers a good purpose, as I will now mention. There are many anglers who, from choice or necessity, dispense with the reel in black bass fishing. Oftentimes the character of the stream is such that a reel can not be used to advantage; for instance, on streams that are narrow, and much choked with snags, roots, and other obstructions, that preclude the playing of a fish, a reel is not necessary, for the fish must be killed within a few feet of where 
it was hooked, and must, of a necessity, be landed as soon as possible.

In this case, a long, light, and pliable - but not too limber - rod must be used, say a natural cane pole, twelve or eren fifteen feet long, with the finest and smallest line that can be procured, which, in this case, is the twisted silk line. This line is made of very small caliber, nicely tinted, of a suitable color, and is quite strong. It is manufactured in connected lengths of fifteen feet, which is about the right length of line for this kind of angling. The sizes run from No. 1, the smallest, up to No. 5, the largest. The smallest, or No. 1, is the size to use, always, when fishing on streams; but for pond or lake fishing, where pickerel abound, No. 2 or 3 may be substituted.

Next to the silk line, in order of merit, comes the twisted or relaid sea-grass line, domestic or Japanese, the latter being the best. They are numbered in the same way as the silk line, No. 1 being the smallest size, and the preferable size to use. Many anglers, notably in the border and southern states, use the sea-grass line for a reel-line, in preference to all others, because it is strong, of small caliber, quite hard and elastic; and, as they do not east very frequently, it answers pretty well, but, as stated before, will kink when much casting is practiced. The sea-grass line is both twisted and relaid, the latter being the best, as it does not kink quite so badly as the twisted line. In relaid lines, the strands are three in number, each strand being twisted from left to right, and the strands twisted together in the opposite direction, or from right to left.

On the score of economy, twisted flax and cotton lines are sometimes used for rod-lines; but they are beneath the notice of the black bass angler, as the sizes are too large to be used for this purpose. 


\section{Hand-Lines for Trolling.}

There are many persons who can not, or will not, use a fishing-rod, but who greatly enjoy trolling with the handJine and spoon-bait for black bass. For the benefit of these unfortunates, I will say that the only line suitable for the purpose is a braided or plaited linen or cotton line, size C or D ( 1 or 2$)$. Such lines are large enough to prerent cutting the hands, and they will not kink or twist, qualities that are peculiarly essential for this kind of fishing. A twisted line, of any material, is inadmissible here, for the revolving of the spoon, if a swivel is not used, will cause even a braided line to twist on itself and kink; therefore, one, or even two, swivels should always be attacheil to. and near, the spinning-bait. A trolling hand-line should be from twenty-five to fifty yards long. 


\title{
CHAPTER XII.
}

\author{
SILK-WORM GUT.
}

"But if you can attain to angle with one hair,- you shall have more rises, and catch more fish."-IzAAK WALTON.

THE material of which leaders and snells are composed is a mystery to many anglers. It is eminently fitted for the purposes mentioned, being as nearly invisible as any substance can well be, and at the same time is quite strong and impermeable to water.

It is really the "fluid silk" of the silk-worm (Bombyx mori), drawn out into a continuous length. This fluid silk, which in its natural state resembles colorless varnish, is contained in two long eylindrical sacs, many times the length of the worm, and which are capable of being unfolded by immersion in water, when the fluid silk can be drawn out into filaments, longer or shorter, coarse or fine, as may be desired.

Most of the silk-worm gut is produced in Spain, and some in Italy. When the worm is about to spin its cocoon it is killed by being immersed in vinegar, which perhaps has also some effect on the viscid fluid in the sacs. These sacs are then stretched, the fluid being drawn out until the proper length is olstained, when the two ends are wound around pins driven into a frame. Afterward the adhering skin or membrane is stripped off, leaving the gut fibre white and glistening. It is then sorted according to thickmess and quality and tied in bunches. The various grades are known to the trade by Spanish names.

It has long been known that from the larva of several species of our native sill-worm moths, much longer strands 
of gut, for leaders, can be produced, than from the Chinese silk-worm; but, while strands of satisfactory lengths have been frequently taken, there seems to be a -want of some special knowledge, or a lack of some peculiar skill in the proper treatment or manipulation of the larvæ, or the silkglands, or in the drawing out of the fluid silk, in order to produce the silken strands of the desired strength.

Dr. Theodatus Garlick, one of the fathers of fish culture in the United States, stated that he had produced strands of from four to six feet in length from the cecropia moth (Platysamia cecropia), which was strong enough for salmon fishing.

Among those who have been interested in the matter is Mr. Chas. F. Orvis, of Manchester, Vermont, who, having procured a number of cocoons of the two species of native silk-worms, Platysamia cecropia and Telea polyphemus, hatched and raised the larvæ rery successfully. In an article in "Forest and Stream," 1856, December 16, giving a history of his experience, Mr. Orvis says:

"We drew many strands from both varieties, each worm giving two strands, $i$. $e$, one from each sac. Before drawing, we put the worms in a dilute solution of acetic acid, or of weak yinegar, which seems to render it more tenacious. After leaving them for a few hours, they were taken out and drawn to their greatest length, as related in regard to the Chinese worm. The length was all that could be desired, for we obtained from the cecropia strands over three yards (nine feet) long, and from the polyphemus strands nearly as long; and the color was perfection, $i$. e., delicately tinted either green or pale brown, according to the variety. But alas, our hopes were vain; for the next day, when they had dried, we found that they had but little strength compared with the product of the Chinese worm. It could hardly have been in the drawing, for we had previously drawn gut from the Chinese worm, proceeding in the same manner, and it was hard and strong. We drew many strands, but all with no better success." 
It is to be hoped that experiments in this direction will continue to be made, until the native gut can be produced fully as strong as the best Spanish gut. If it can be done there is a fortune in it for somebody, for a leader in a single piece of from six to nine feet in length, and as strong as the Spanish gut, will bring a good price.

An easy way to experiment in the matter would be to collect the fully grown larve just before they are ready to spin their cocoons, as they are quite plentiful in the central portions of the United States, especially in button-bush or water-sycamore swamps. In order to enable any one to identify the moths and their larræ, the following good descriptions are abridged from C. H. Fernald ("Standard Natural History," S. E. Cassino \& Co., Boston, 188t, vol. II, pp. 456-457) :

The Cecropia silk-worm. Platysamia cecropia, which has a wide distribution in the United States, is one of our largest moths, expanding six inches or more. It has a most remarkable appetite, feeding on no less than fifty different species of plants, among which are the apple, plum, maple. elm. oak, beech, birch, willow, etc. The female lays from two to three hundred eggs, which are creamy white and striped with reddish, and hatch in eight or ten days. The young catterpillars are black, and change in color and size at each moult until mature, when they are three or four inches long, and of a pale green, or bluishgreen color. The tulhereles on the third and fourth segments are coral red; the others on the back are yellow, except those on the second and last segments, which, with those along the sides, are blue; and all are more or less armed with black bristles. They construct elongated, coarse dull brown cocoons. The wings of the moth are of a rich brown color, sprinkled with gray scales, with a large 
kidney-shaped spot, shaded more or less with red, and margined with black, near the middle of each wing. A red band, edged on the inside with white, crosses the wings near the middle. The outer edges of the wings are pale silky brown, through which runs an irregular black line on the fore wings, and a double broken band on the hind ones. The base of the fore wings is dull red, with a curved whito and black line, and near their apex is a black eye-spot with a bluish crescent in it, and a shade of lilac above.

The American silk-worm, Telea polyphemus, is our best native silk-producing species. Each female lays from two to three hundred eggs, which are about one-sixteenth of an inch in diameter, slightly convex on the top and bottom, the convex portions whitish, and the nearly cylindrical sides brown. These hatch in from ten to twelve days. The caterpillar feeds on the leaves of oak, elm, etc., and when full-grown is over three inches long, of a light-green color, with seven oblique yellow lines on each side, and the tubercles on the segments orange with a silvery spot on the middle. The last segment is bordered by a purplish brown $\mathrm{T}$-shaped mark. It spins a whitish oval cocoon, which often falls to the ground, where the insect remains during the winter in the pupa state.

Those especially interested are referred to the articles of Mr. Trouvelot, "American Naturalist," 1867, for his experience and methods of obtaining the silk, and in rearing the American silk-worms.

\section{Leaders, or Casting Lines.}

The silk-worm gut imported into the United States, and used for leaders and snells, is usually in short lengths of from twelve to fifteen inches. In forming leaclers, these are knotted together to the desired length. There are 
many grades of gut, and the angler will do well to remember that the best is the cheapest.

Black bass leaders should be six feet long, and composed of the best single Spanish silk-worm gut, sound and strong, hard and round. The gut lengths should be perfectly clear and sound, quite smooth, and without inequalities or rough places. The rod-end of the leader should be composed of a large-sized gut, the next length a trifle smaller, and so diminish by a gradual taper to the fly-end. The several lengths should be neatly and firmly knotted together and the ends cut off closely. It should be remembered that it is necessary to soak and soften the ends of the gut-lengths previous to tying.

T'oo much care can not be exereised in selecting the leader, for upon its soundness and excellence depend much of the pleasure and success of fly-fishing. It should be carefully examined in every inch of its length, and the knots closely inspected. The leader may be stained some suitahle neutral tint; a slightly greenish, grayish, or smoky hue will answer. Strong green tea, diluted black ink, or a weak solution of indigo, make good stains.

Anglers, now as ever, are continually theorizing and speculating as to the most suitable colors for leaders, in order to render them as little discernible to the fish as possible. Many experiments to this end have been made by using aquaria, or glass tanks especially constructed, or by the experimenter putting his head beneath the surface of the water, in order to view the leader through the same medium as the fish.

But the praiseworthy experiments to determine the color of leaders least visible to the fish, however commendable, are sure to end in disappointment; such, at least, has been my experience. Experiments to this end have been made 
by practical anglers for many years with no other result than to show that the finer the gut the better, without reference to color. My own experiments in this direction have not been few, and I have demonstrated, to my own satisfaction at least, that any color of leader or snell will answer, from hyaline to black, though I confess that I was formerly partial to a slight bluish stain, or mist color, and perhaps without any well-defined reason, except that it ought to be least visible to the fish.

But when we enter the province of speculation and conjecture, and try to see for the fish, or, in other words, to measure their risual capacity by our own, we are doomed to disappointment, though we bring to our aid all the known resources of the science of optics.

The only way to experiment with profit, in this direction, is to experiment with the fish themselves, otherwise our efforts will be like the play of Hamlet with the melancholy Dane left out. The sense of sight in fishes is but little understood, as is, indeed, the anatomy of their risual organs, which fact precludes all analogous reasoning from our own standpoint, alone. I have satisfied myself, however, that they see as well in their own element, perhaps better, than we in ours.

That the color of the leader is not important is very evident when we reflect that the boy with line of wrapping cord, red, white, or blue, or the angler with line of twisted strands of black sewing-silk, to which the hook is affixed without leader or snell, is as successful in taking trout or black bass with bait, as others with lines of the most approved colors. Sharks do not hesitate to take the bait even with the huge hook and chain and swivel accompaniment, nor do codfish, and other marine fishes, refuse the bait because of the large hooks, wire snells, or coarse white lines; 
yet it is to be presumed that their discernment is as acute as that of a brook trout.

As to leaders and snells in fly-fishing, I do not think it makes much difference, practically, as to their color. The greatest desideratum, it scems to me, is to have them as fine as possible, consistent with the strength required, and this is not much with a flexible rod, for the amount of strain exerted ly a fish on the rod and tackle is very much less than is popularly supposed. Though any color may answer, I prefer lines and leaders of natural tints as being more in accordance with the eternal fitness of things. Although staining may not weaken the gut, it certainly can not add to its strength; it is best, therefore, I think, to use leaders and snells of unstained gut. As it is almost transparent, it is less likely to be seen than a stained leader. I have used, with success, snells and leaders of the finest silver suture wire, for trout and black bass, but, practically, they are not pliable enough, and are too heavy.

On the whole. then, I think we shall have to be content with our loaders and snells as we find them to-day, simply selecting those that are the finest, roundest, and most perfect, remembering. meanwhile, that a sight of the angler himself is more fatal to successul fishing than a display of the coarsest leader, or of the most oljectionable in color.

Leaders are now made with loops for attaching the dropper flies. and is by far the most preferable way. An excellent mode of making the loop is as follows - and if the reader will refer to Fig. 11, on page 228, and its explanation on page 229. the matter will be made much clearer. In forming the usual knot for tring the gut lengths together in making a leader, the two ends are lapped about two inches in forming that knot; but to make the loop, lap about four inches, and rlouble one strand back on itself, so 
that there will be then three strands (instead of two), presented for tying, each about two inches long - two of the strands forming the loop; now tie the knot in the manner as shown in the illustration referred to, and draw tight. This will leare two short ends on one side of the knot, and a loop on the other; the former are to be clipped off short. This loop should point toward the reel end of the leader, or away from the stretcher fly, in order that the drop fly when attached may stand at a right angle to the leader, and thus prevent it becoming curled around it, when wet.

A rery good plan of making leaders is that used by some anglers. who tie the gut strands together in lengths of three feet, with loops at each end. Two of these lengths can he looped together for a six-foot leader. The flies can also be attached to these looped ends very easily. In this way a number of casts can be prepared, which may be used as found necessary. If the angler in using, say, a leader of six feet made in this way, with the stretcher and dropper flies attached to the end loops of the lower threefeet length, it will readily he seen how easy it would be to change the cast by simply "unlooping" the leader in the middle, and looping on another three-feet length - with flies already attached - as before. It will also be seen how easily a leader can be repaired in the same manner, by discarding the broken or frayed portion and replacing it with another three-feet length.

In testing the strength of leaders for black bass fishing. the angler should he very careful not to apply a force or weight of more than two or three pounds, which is really more than it will require in actual fishing, and is all the strain a leader can he put to without injury. Silk-worm gut is always weakened when tested to the breaking point, or one of six or more pounds; thus, a leader that breaks at 
eight pounds at the first trial, will not be likely to sustain more than six pounds at the next, and still less at the third trial. But if a low test is applied, as suggested, a good leader will last until worn out, in actual fishing. There is really no necessity for testing a first-class leader, for black bass or trout fishing, when bought from a reputable maker.

\section{Snells, or Snoods.}

For utility and conrenience, hooks are tied on short pieces of gut, gimp, or sea-grass, called snells, or snoods. The best material for snells is silk-worm gut, as it is light, strong, and nearly invisible. It may be stained of a similar color and in the same manner as the leader.

The length of snells for black bass angling should be from three to five inches; and they should be composed of single, heary gut, though they may be made double if the gut is very light or fine.

Tnless eyed hooks are used, the tapered shank hook should be neatly and securely tied to the snell with waxed silk and varnished, and a loop formed on the other end of the snell for attaching to the reel line; the end of the gut should be softened and rendered pliable by soaking it in water before tying the loop.

For fishing in waters where pike, pickerel, or pike-perch arr numerous it may be advisable to substitute gimp of the smallest caliber for the gut snell, as the long and sharp teeth of those species would make short work of the delicate gut fibre by fraying or cutting it.

If eyed hooks are used the snell has simply a loop tied at one end. learing the other end to be affixed to the hook by a jam, or other, knot.

Most black hass flies are now made with a short loop, or eve, of double gut, instead of being tied on snells of sereral 
inches in length. This is much the best way. They can be as easily looped on for stretchers, and by using separate snells looped at each end, they can be as readily attached for droppers. These separate snells should not be more than three or four inches long; and when the fly is tied directly to the snell, the latter should not exceed four inches in length-- three inches is really long enough. Short snells or droppers will stand out better from the leader than longer ones, and they fit the molern fly-books much better.

The "cye" or loop of the fly may be formed of the smallest sized wire gimp, instead of gut, as it is stronger, and cannot become chafed or frayerl. It will, howerer, increase the weight of the fly somewhat; but this will be no disadrantage in fly-fishing for black bass.

\section{KNots.}

In angling, as in sailing, there is no accomplishment so necessary, or that proclaims the finished angler or sailor so well, as his ability to tic a good knot. The beginner should study the plate of "knots" thoroughly, and by practice learn to tie each and all of them readily and propcrly. I have seen otherwise good anglers who could not tie a correct or graceful knot, and the knife was always brought into requisition to "untie" their clumș efforts; in this way their lines became shorter daily, and "beautifully less."

There is always a right way and a wrong way to do every thing: and though a knot may seem an unimportant thing, it is really often a most rital one, many times causing the angler to lose a good fish, and might result in the loss of his life to the sailor. The new hand will please remember that whatever is worth doing at all. is worth doing well. 
Fig. 1 is the "common" knot for forming a loop at the end of a line, or snell. It has its uses.

Fig. 2 is the best knot for tying such a loop; it looks a little intricate, but can be learned by practice, and once learned, will be a "well-spring of pleasure."

Fig. 3 is a good and simple method of attaching the recl-line to the loop of the leader, or snell. It is the "tiller-hitch," or "helm-knot," so-called because it can be instantly cast off by a jerk on the end; being thus the safest hiteh for the main-sheet in sailing.

Fig. $t$ is a more secure knot for attaching the end of the line to lnop of leader, or snell; it makes a small and neat knot, and is easily untied. It is the "becket-hitch," with a small round knot in the end of the line to prevent its working loose.

Fig. 5 is another method of fastening reel-line to loop of leaklur. or snell: it is a very safe and secure knot, and is a modification of the "reef-knot" (fig. 10).

Fig. 6 is similar to fig. 5, with the end of line fastened on itself by a half-hiteh; it is very secure, but a little more difficult to untis than fig. 5. Figs. 3. 4. 5. and 6 are all good linots for benting the line to loop of leader, or snell; they draw up (tose ald snug, will not slip, and are easily lnoseneil. The angler can take his choice, but he should never tie his line and leater together by the eommon knot (similar to fig. 1), or the square knot (fig. 10). The leater should always be provided with a loop in each end, neatly seized with goorl serving silk, and rarnished. In bait-fishing. a loop may le formed on the end of the reelline, hy which it may be fastened to one ring of the swivel, when it is desired to pass the loop of the snell through the opposite ring.

Fig. " is the "single water-knot," for tying lengths of 
gut together to form the leader; it consists of half-hitches at the ends of the gut lengths, which are formed around the opposing gut-lengths, as shown in the figure; this forms a sliding knot for securing the end of the snell of a drop-fly.

Fig. 8 is the "double water-knot" for the same purpose as fig. 7; it is more secure, but not so neat, as double hitches are used in its construction, as plainly shown in the figure.

Fig. 9 shows the method of fastening the snell of a dropper by the single or double water-knots. After the two parts of the water-knot are drawn tight, as shown in the figure, a round knot is made in the end of the snell of the fly, and is put through the open loop between the two halves of the water-knot, which latter are then drawn together close and snug. holding the snell tightly and securely. By using this mode of attaching droppers to the leader, they stand at right angles to it, and may be changed as often as desired, and with but little trouble, by simply sliding the water-knots apart, taking out the snell of one fly and inserting another. The flies can not pull out, as might be supposed, for the strain and struggles of a fish only serve to make the knot draw more closely together. This plan, howerer, is not much used now, nor are the water-knots; the more modern plan of using leaders and snells with loops, as described on page 223, haring superseded them.

Fig. 10 is the "reef-knot." or common square knot, and is a very safe and strong knot for many purposes; it never slips or jams, when properly tied, and is easily lnosened; but in tying this knot, if the second turn or hitch is not made exactly right, it forms a "granny-knot," than which there is no worse or more uncertain knot made. and yet 

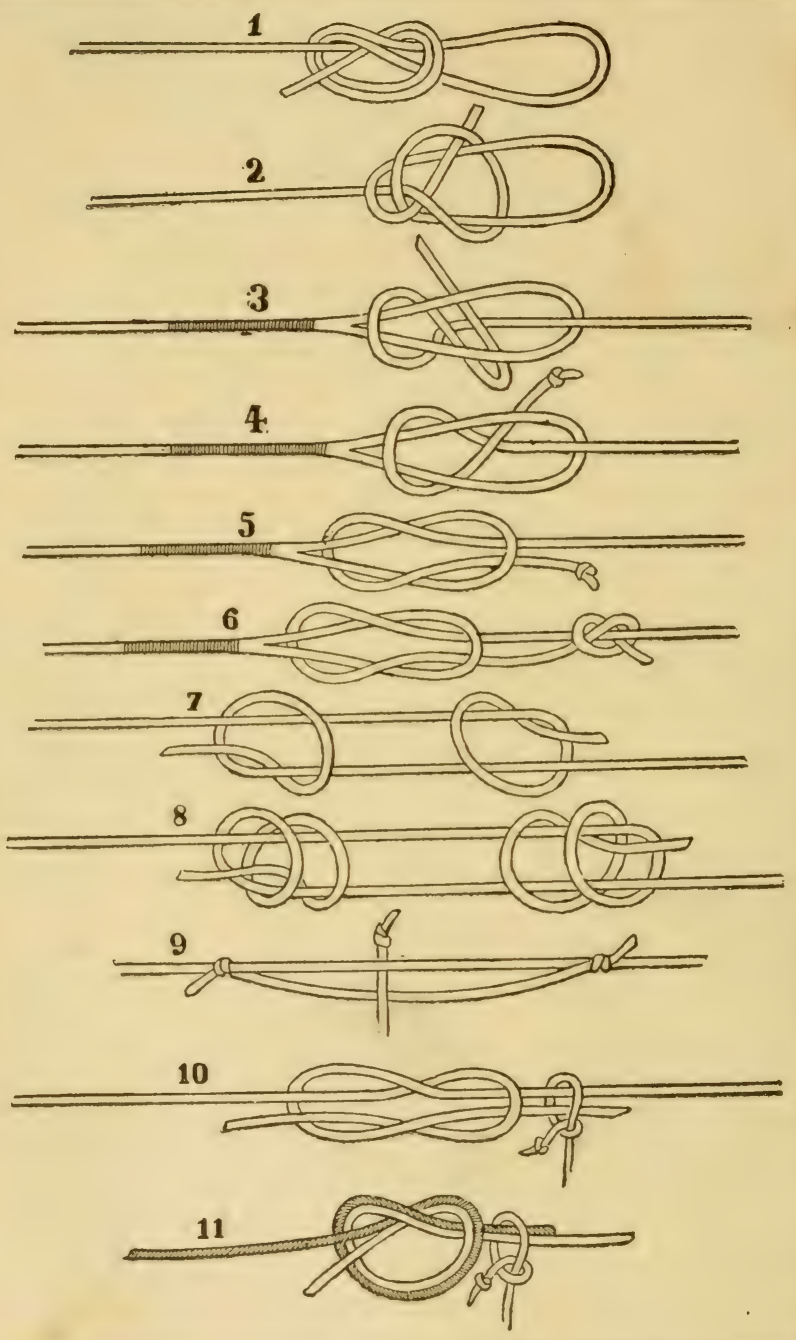
nine persons out of ten tie a "granny-knot." The novice will do well to study this common knot, and learn to tie it correctly. It is sometimes used for tying the lengths of a leader, in which case, as also with the single waterknot, the ends should be cut off closely, and neatly whipped with fine sewing silk and varnished.

Fig. 11 is the form of knot generally used by manufacturers of leaders, or casting lines, for tying together the gut-lengths; it is a very simple knot to tie, though it looks somewhat difficult in the figure, and in the way that I have seen some attempt it, is a difficult knot. I have drawn the two lengths of different colors, one white, the other dark, so that the construction of the knot can be more easily seen. The ends of two gut-lengths are passed l,y one another, or in other words lapped. sufficiently to allow of their being tied by a single hitch and drawn tightly, just like tying a single, knot in a double string (as in fig. 1). Usually the knot is made double by passing the ends of the gut through twice, instead of but once, in tying; that is by simply tying what is known as a "surgeon's knot" (for ligating arteries) with a double thread. The short ends are then trimmed off closely. If a leader is made with loops for attaching lrop-flies, this is the best knot to use in making the leader itself, being, like fig. 10, secure and unyielding.

Where knots like figs. 10 and 11 are used in constructing the leader, and no loops are provided for attaching droppers, the latter must be secured by a half-hitch, just above a knot in the learter, as shown in figs. 10 and 11 , which is a very good plan. It must be borne in mind. that in tying lengths of gut together, or in tring loops or knots in gut-snells, the ends must first be soaked in water until quite soft and pliable; this must also be observed in bending or tying a hook on a gut-snell. 


\section{CHAPTER XIII.}

HOOKS.

"For in the Prophet Amos, mention is made of fish-hooks; and in the book of Job, which was long before the days of Amos, for that book is said to have been written by Moses, mention is made also of fish-hooks, which must imply anglers in those times."IZAAK WALTON.

TuE best fish-hooks are made in England, that country supplying the world with hooks of all sizes and styles, for all kinds of fishing. The town of Redditch has been famous for its fish-hooks for at least two centuries. There, are located the celebrated makers. Harrison, Hemming, Millward, Bartleet, Warrin, Bates, Alcock, and others, whose familiar names are almost synonymous with hooks and needles, both articles being usually made by the manufacturers mentioned.

There are fish-hooks and fish-hooks, and to the uninitiated one hook is as good as another; all they can see in a hook, is the fact that it has a shank, a bend, and a bearded point. But to the angler this contracted view is not sufficient. There are many styles of shank, numerous forms of bend, and various ways of fashioning the barb and point, all of which are of the highest practical importance. Some hooks are male for general service, while others are formed exclusively for particular kinds of fish, or for special methods of angling. The fish-hook of to-day is not essentially different from that used by the ancient Greeks and Romans, to the casual observer: but to the practiced eye, the hooks now produced, for form, temper, and strength have never been equaled in the history of the world. 
The form, quality, and general excellence of hooks, as now made, is the result of the competitive slill and great experience of the manufacturers of Redditch, England, whose energies and resources have been directed in this peculiar channel for nearly two hundred years; and, as might be inferred, as between the hooks of the first-class makers, there is but little choice, so far as quality and workmanship are concerned.

There is no implement of the craft that is so unirersally kept in stock at the small stores and shops throughout the country, as the fish-hook; and these hooks, as a rule, are of rery inferior quality, as might be inferred when we take into consideration their cheapness, notwithstanding the fact that they must net the dealer at least fifty per cent. profit, or he would not sell them.

While the average angler is inclined to use hearier rork, and stronger lines, than are actually necessary, he does not seem to be so much impressed with the importance of strength in a fish-hook, but accepts those of the small dealers mentioned, with the blind faith that a hook is a hook, and that one is as strong as another. if of the same sized wire; and, moreorer, he recognizes but two forms of hooks, the Kirby, or side-bend, and the straight, or more or less rounding-bend.

Now there are no fallacies so great as these. for the hook is of the most vital importance to the angler, and he should obtain the very best to be had, hoth in form and quality. Fish-hooks, in themselves, being of so comparatively small a price, it is the most insane idea of economy to purchase any but those of the rery best quality. The most approved form of bend and harb, should also be taken into serious consideration.

The highest grades of English hooks, like English gun- 
barrels, are thoroughly tested by causing them to sustain a strain, twice or thrice as great as they are usually put to in actual service, and the extra care and manipulation, and the superior stock used in the construction of such hooks, make their cost somewhat higher; but this extra amount is money well expended, for the angler can rely upon them with the utmost confidence, provided they are the product of the hest makers: there is but one thing left to decide his choice among such hooks, viz., the peculiar bend or form given to the hook, of which there are several that are good enough. I might add, that all first-class hooks are japanned, or bronzel, and that a blued hook is always of an inferior quality.

The most approved hooks for black bass, are the Sproat, O'Shaughnessy. Dublin Timerick, Cork-shape Limerick, round bend Carlisle, or Aberteen, and hollow point Limerick; they are best in the order named.

As regards the shape and hend of a hook, my first choice for black hass angling is the "Sproat bend," and the next best form, in my opinion. is the "O'Shaughnessy." In general form and hend the two hooks are identical. but their differenee consists in the form of barb, and direction of the point. In the latter peculiarities, the Sproat is fashioned after true scientific principles, being a centraldraught hook; that is. the short, squarish, or somewhat angular barl, lerminates in an ahrupt point, which, if continued upward, would intersect a line drawn from the extremity of the shank and continuous with it. In other words, the direction of the point of the hook is toward the end of the shank.

When the Sproat hook is tied on a snell. and the point of the hook is held against the ball of the thumb, and traction made on the snell. the direction of the point of 
the hook is on the same plane, or in the same direction or axis as the line of the snell, thus constituting what is termed a central-draught fish-hook. The wire of the Sproat is a trifle smaller than the O'Shaughnessy, which is another advantage. The latter hook has a long and somewhat hollow point, which is curved outward.

The Sproat bend I regard as the very best hook manufactured. I first commenced its use thirty-five years ago. Its appearance is somewhat against it, but it is like " a singed cat." By the side of a delicate, blued, gracefully-shaped Aberdeen, it looks black, and rather clumsy, with its short barb and peculiar bend, but it means "business." Its temper is just right, and when you strike a fish it goes right through any part of the mouth, never springing out, and never disanpointing you. I have had the Aberdeen so soft as to completely straighten and pull out, and so brittle as to break like a pipe stem, but the Sproat has yet to fail me. For staying qualities it is perfection itself.

The "Dublin bend," or Dublin Limerick, as it is sometimes called, and the "Dublin Limerick forged," are excellent hooks, and are identical in form and bend with the 0'Shaughnessy hook, the only difference consisting in the caliber of the wire, which, in the latter, is a trifle heavier. The forged Dublin Limerick has the wire flattened by hammering or forging; it is a remarkably strong hook.

The "Cork-shape Limerick" has an almost round bent. with a straight shank, and a long straight point, which is parallel with the shank in its direction, and a very good hook, being of rather smaller wire than the Sproat.

The "Carlisle" hooks are made of very small wire, and are very delicate and attractive to the eye, but for black bass fishing I do not admire them, though, until I came across the Sproat hook, I used the round bend Carlisle 


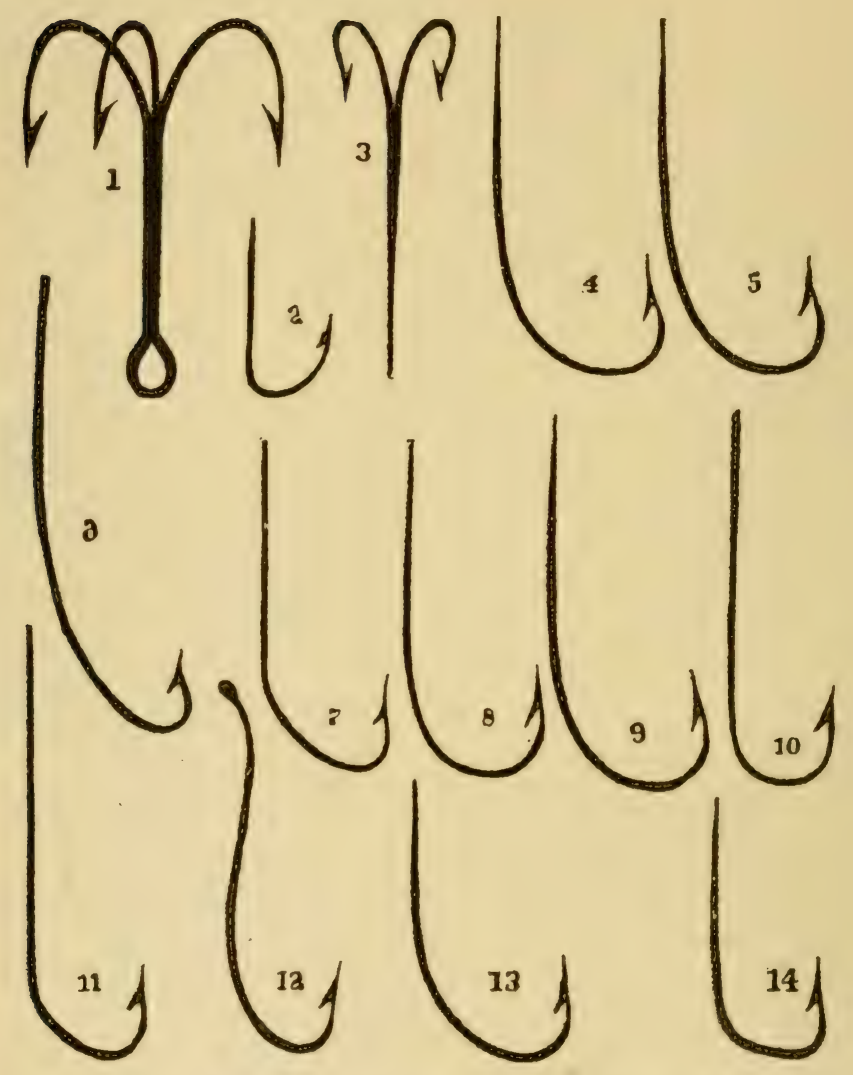

1. Triple hook.

4. Dublin bend.

\%. Limerick.

10. Aberdeen.

13. Kinsey.
2. Lip hook.

5. O'Shaughnessy.

8. Cork shape.

11. Kirby Carlisle.

14. Sneck bend.
3. Double fly-hook.

6. Chestertown.

9. Sproat.

12. Gravitation. 
(Aberdeen) altogether. Still, many anglers prefer them on account of the small wire, which is not so apt to injure the minnow; but I might say here, that if a minnow is put on with care, it need not be injured to a greater extent, (ren with the forged Dublin bend hook, than with the Carlislc. The round-bend Carlisle, or Aberdeen hook, has a perfectly round bend, and a long straight shank; the barb is long, with the point curving outward.

The "hollow point Limerick" is a very old form of hook, and is still a great favorite with many, notably the veterans of the angle, whose experience with this hook dates back to the heyday of youth. The form of the Limcrick is well known; it has a straight shank, and a very abrupt bend, with a long, straight, and hollow point.

The Kirby Carlisle, the Kirby Limerick, and, in fact, any hook with the "Kirby" or side-bend I can not recommend for any kind of angling. It is the worst possible crook that can be given to a fish-hook, being both unscientific and impracticable.

The needle-pointed, or hook without a beard or barb, has been recommended for fly-fishing, but it will not answer for the black bass. So long as the fish remains in the water, and a proper tension of line is maintained by the angler, it holds as well as any other hook, but when the fish leaps from the water in its struggles to free itself, like the black bass, there is a great liability of its shaking out such a hook.

Artificial flies, tied on extremely small barbless and needle-pointed hooks with a circular bend, have been used in Japan for centuries, and while such hooks may do for the brook trout, and fishes closely allied to it in habits, they are totally unsuitable for the black bass, or any fish that makes such desperate efforts to get away, when hooked. 


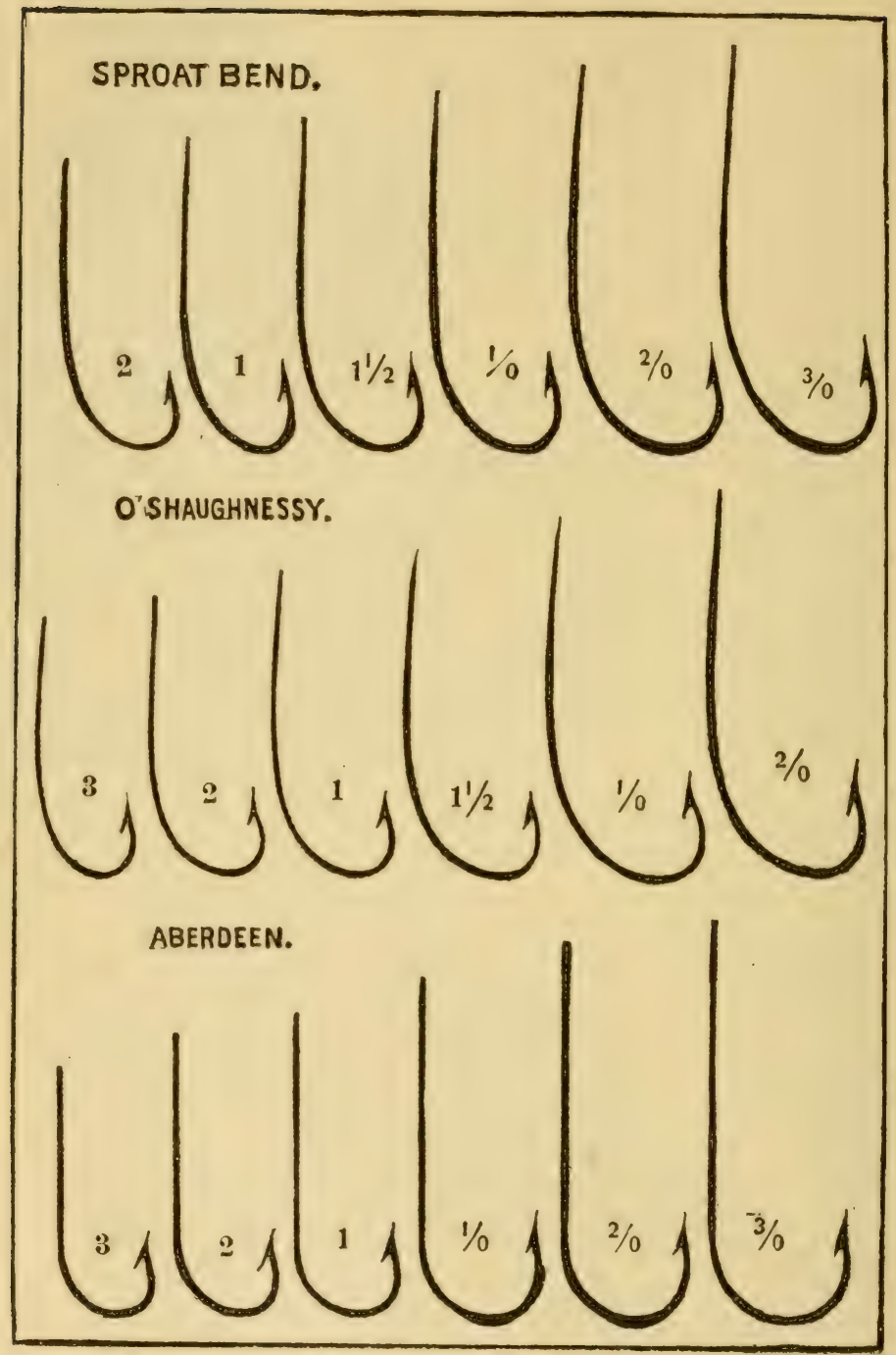


The Edgar patent barbless hook, furnished by William Mills \& Son, is made upon a very different principle. This hook, while having no barb, has a "keeper" which securely holds the fish after it is hooked, rendering it almost impossible for it to escape, even with a slack line. It is the only "patent" fish-hook that has any real merit, though it seems to me like taking too much advantage of a fish, and is likely to foster and encourage a careless and shiftless style of angling. Still, it may become quite a favorite hook with many. To my mind the great charm of angling consists in using a proper judgment (born of a thorough knowledge of the fish and its habits) in presenting the bait, and the exercise of skill and science in hooking, playing, and landing it.

Mills \& Son have applied for a patent on a new form of barbless hook. At the bend of the hook the wire is turned on itself, forming a loop, and then continued up to the point. This loop answers the same purpose as the keeper of the Edgar hook. It has also a vertical eye.

Recently the old "ejed" hook has been revived in England for artificial flies, but with this difference: the oldfashioned form had the eye rertical, that is, on the same plane with the shank, while the improved eye is either turned up or turned down; though some prefer it turned up, the turned down eye is deemed the best form. Through this eye the snell is passed and fastened by one of several knots or hitches, each of which has its advocates.

But the black bass fisher need not worry his brain as to whether the eye should be turned up or down, nor fret his soul as to the particular knot or hitch by which to attach the snell; for the plan of making the eye of gut or gimp in bass flies is really to be preferred to any form of eyed - hook, as the loop of the snell can be rearlily passed through 
the small gut loop at the head of the fly, and over the latter, and then drawn tight, making a very neat and secure attachment - neater and more secure than by any form of eyed hook with knotted snell. The eye of the new hook is so small that, except in large sizes, a doubled gut can not be passed through it, consequently it must be fastened by a single gut with some sort of knot. It is best suited for the very small hooks, on which the trout flies of England are usually tied, and for the very finely drawn, or gossamer gut, of which the snells are made.

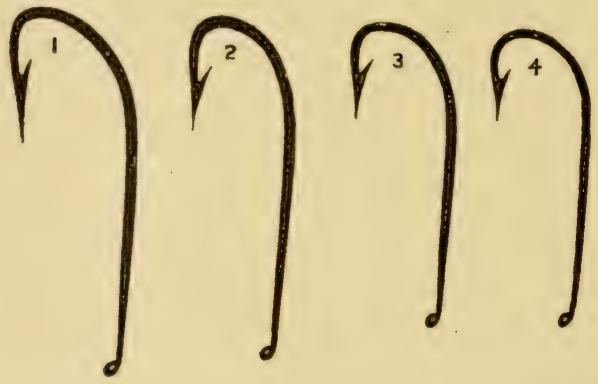

The eyed hook is. however. gradually coming into rogue, especially for small trout flies, and to some extent for small bass flies. The Pennell turner-up eye seems to be the farorite, though the Hall turned-down eye is perhaps as good. at least so far as the form of the eye is concerned.

I have found a lack of uniformity in the size and form of the eye in both hooks, and in many the eye is not smoothly finished.

Heretofore the eyed hooks have all been of the Limerick pattern. but lately they are being made with the Sproat bend, which is better adapted for small bass flies.

There are several kinds of knots used for fastening the 
snell to the eyed hook, which are shown in the accompanying illustrations, and which explain themselves. The simplest jam knot is as good or better than the more complicated ones.

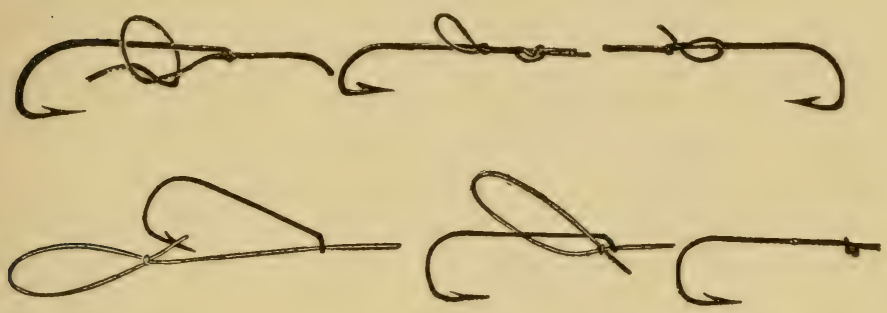

A needle-eyed hook has also been introduced by Wrarner that has the eye formed near the end of the shank, much the same as in a sewing needle.

With the advent of the eyed hook came a change in the system of numbering them styled the Kendal scale, which is the reverse of the one heretofore universally used - the Redditch scale. Concerning this the late Mr. S. Alcock has this to say:

"In Redditch we number from 1 to 20 , the size becoming smaller the higher the number, in the same way that the wire is numbered. This is logical, for the finer the wire the more frequently must it be drawn through the plates to reduce it. The sizes larger than No. 1 we number $0,00,000$, etc. This system has worked well for centuries.

"Now, however. a manufacturer employing a very few hands chooses to number his hooks backward, 20 being a large size and 1 a smaller size: those smaller than No. 1 he calls $0,00,000$, etc.; and Mr. Pennell has written a book in which he adopts this numbering: but the only reason given for this new srstem is that 'it is sufficiently elastic, allowing of extension either wav.", 
As the hools that are most in rogue in the United States, as the Sproat, O'Shaughnessy, Carlisle, Aberdeen, Dublin bend, and hollow-point Limerick, are all numbered according to the Redditch system, and agree very closely in all the sizes, it would be in the nature of a calamity to change it for the Kendal or any other system.

\section{SNelling Hooks.}

It has been recommended, in tying gut snells to hooks, to heat the shank of the hook and coat it with rubber or other cement, or wax, and to soften the gut by soaking, or to crimp it by biting with the teeth or pinching it with pliers; but let me caution the tyro, and adrise him to do nothing of the kind. It destroys the temper of a hook to heat it, and burns off the protective coating; it breaks the fiber of the gut to bite or crimp it; and when the gut is expanded by soaking and tied on, it shrinks upon drying, and leaves the wrapping loose.

The best way to tie a gut snell to a hook is to use nothing but well-waxed silk thread, and to wrap evenly and tightly. If properly done it will never pull off. Rubber cement loses its life after a time, becoming brittle, and rots the silk wrapping; and so will all cements, sooner or later, from constant wetting and drying. At the best, if they do no good they may do harm, and it is folly to use them when they can better be dispensed with.

In tring a hook to gut, use the best sewing silk - the finest for very small hooks and coarser for larger ones; use red shades as they seem to be stronger, and the color is suitalle. The silk must be well-raxed, and there is nothing better for the purpose than the best light-colored shoemaker's wax, which can be folded in a piece of soft leather to prevent soiling one's fingers. 
Some writers advise laying the gut on the back of the shank, but it is much better and more proper to place it on the front or inside of the shank. When it is on the back the direction of the traction and the strain is away from the end of the shank, and has a tendency to stretch or loosen the wrapping at that point; while with the gut in front of the shank this is obriated, as can be easily demonstrated, by placing the point of the hook against the ball of the thumb and making traction on the snell.

Now, then, to tie a tapered hook to gut, proceed as follows: First wax the silk well; then take the hook between the thumb and forefinger of the left hand (if you are righthanded), with the end of the shank to the right, and the barb uppermost; beginning at about the middle of the shank make sereral spiral turns of the silk to within onethirty-second of an inch of the tapered point, then lay the gut along the inside of the shank for half its length, for small and medium-sized hooks, or one-third for large hooks, and begin wrapping the silk around the gut and shank, and wrap firmly, evenly and closely down toward the bend of the hook, using as much strain in wrapping as the silk will bear, and continue the wrapping for a short distance, or six or eight turns, below the end of the gut. Begin the wrapping just below the end of the shank, learing its tip bare, and finish the wrapping with the invisible knot.

The invisible knot is formed in two ways: one by reversing the hook in the fingers of the left hand, so that the shank points to the left, and laying the silk along the shank with its end beyond the end of the shank, learing a loop of the silk to continue the wrapping, around the shank, gut and silk, passing the loop over and around the bend of the hook at each turn, until four or five turns are made, and then drawing the silk back by its end, through the turns, 
drawing tightly, and clipping off the end closely. It is more easily done than described.

Another way of making the invisible knot, or rather a different way of doing the same thing, is to lay a doubled thread of fincr (unwaxed) silk along the wrapping, its loop) being toward the hend of the hook, and include this doubled thread in the last four or five turns around the shank and gut, lout not wrapping quite so firmly as before, and then pass the end of the wrapping silk through the loop, by means of which the wrapping thread is pulled back and out under these last turns, and after drawing snugly and tightly the end is to be elosely elipped off. When the wrapping is completed, it is to be well coated with shellac varnish by means of a camel's hair pencil. 


\section{CHAPTER XIV.}

\section{ARTIFICIAL FLIES.}

"You are tom note, that there are twelve kinds of artificial-made flies, to angle with upon the top of the water."-IzAaK WaLtox.

FLy-Fismmg and the art of making artificial flies dates back at least to the ancient Greeks and Romans. During the palmy days of the Roman Empire, the rod, line, hook, and artificial fly were well known. Noël de la Morinière tells us that the lines were generally made of horsehair, single, double, and plaited; and according to Elianus the hair was colored in different ways. The fishing-rod was chosen with reference to the supposed weight of the fish to be caught, and the resistance it could offer. The hooks were of copper or iron, and coated with tin. The art of making flies of feathers and other materials has, perhaps, been carried not much further in our own time. It is possible that the national love for fly-fishing was introduced into Britain by the Romans.

It is with some degree of trepidation that I approach the subject of artificial flies, for I am afraid that I hold some very heretical notions on the subject. But of one fact I am positively convinced, and that is, that there is a good deal of humbug in this matter, as evidenced in the many fine-spun theories and hair-splitting arguments that are adrocated and advanced (pertaining to the construction and use of artificial flies) by some anglers, but which theories do not hold good in practice.

In England, more especially, do anglers proceed to extremes as theorists in the matter of artificial flies for trout fishing. They seem to be divided, principally, into " col- 
orists," or those who think color of paramount importance to form, and "formalists," or " entomologists," who maintain that form is every thing, and profess to imitate the natural fly, in its proper season, in every particular of form and tinting. But there is no evidence that one class is more successful than the other, as anglers. On the other hand are the followers of Mr. Pennell's system, or plan, who confine themselves to three "typical" flies - green, brown, and yellow "hackles" - and claim that they are sufficient for all practical purposes, and can be made available for different waters and seasons by increasing or diminishing the size of the flies, as circumstances seem to demand. While the adherents to this latter theory are fully as succesful, from all accounts, as those who have a list of nearly a thousand named flies to choose from, and enjoy the satisfaction of having reduced the perplexing matter to a delightful simplicity, and of obviating the troubles of a repeated changing of the cast of flies as practiced by others, they must sometimes feel a regret deep in their hearts for casting down and sweeping away their idols and cherished traditions, and to a certain extent the poetry of fly-fishing, by their iconoclastic though sensible opinions and practices.

Where fish are plentiful and in a "biting mood," almost any fly, be it never so rudely tied, and of the least possible resemblance to any thing in the insect creation, will be successful, eren if clumsily cast; on the contrary, there are times when the best-made flies, cast by the most skillful artists, are necessary to induce a rise. Between these extremes must we look for rules for our general guidance, and without occupying further space with arguments, pro and con. it will be sufficient to say that there are certain general rules which apply to the character of the fly to he used at certain times. and which rules are the result of, and 
founded upon, the experience and observations of fly-fishers for many generations past.

These rules, so far as they apply to black bass fly-fishing, are few and simple:

1. Flies should be small, rather than large, the arerage trout fly being usually large enough.

2. On bright days, and with clear, low, or fine water, flies should be quite small, and of subdued. dark, or neutral tints.

3. For cloudy days, and high, turbid, or rough water. larger and brighter flies should be used.

4. For very dark days, or from sunset until dark, or on moonlight erenings, gray or whitish flies, of good size, should be employed.

I shall not go into an entomological description of flies and their counterfeits, for it is neither requisite nor advisable, so far as bass flies are concerned. For those who feel an interest in this subject, however, I can recommend the several fine works published in England on the construction of trout and salmon flies; among the best of which are Ronald's "Fly-Fisher's Entomology," and Pennell's "Modern Practical Angler." The best book, however, ever written on the subject, and the one most useful to the American angler, is "Favorite Flies and their Histories," by Mary Orvis Marbury.

I will merely state that the majority of artificial flies are of two kinds, and are intended to represent the perfect winged insects of certain orders, and the larvæ of others; thus, most trout flies are the pretended imitations of some of the species of the orders Diptera and Neuroptera, the former comprising the two-winged insects, as the gnats, mosquitoes, midges, ete., and the latter the four-winged insects, as the May-flies, dragon-flies, etc. The larval form of fly is supposed to represent a caterpillar, and is 
called a "hackle," or, more correctly, a "palmer." It must be borne in mind in this connection that an artificial fly, when wet, presents a much different appearance from the same fly when dry, and our flies should be tied with reference to this contingency.

The term "hackle" is likely to cause some confusion in the mind of the new hand, if not explained, for it is susceptible of several meanings as used by anglers and flytyers. The proper meaning of the word is a "feather" from the neck or saddle of the cock, and known as a "neck-hackle," or a "saddle-hackle," as the case may be. These hackle-feathers are used to imitate the legs or feet of an artificial fly; and as one variety of fly consists only of a body with a hackle wound spirally around this body, from one end to the other. this form of fly has come to be known, in this country at least, as " a hackle," though, as stated before, the proper name is "palmer," and it is designed to imitate a caterpillar, for it is only a body bristling with "legs."

Then there is the "hackle-fly," which is a fly with body and, perhaps, a tail, and in addition a hackle-feather tied on at the shoulder, to represent the legs. Some salmon flies have, in addition to wings, tail and feelers, the entire body wound with a hackle, like a palmer. This is known as a "combination-fly," and, like all salmon flies, does not pretend to imitate any thing in nature.

The conventional "fly," or, properly, the winged fly, is the one most generally used. In addition to a body, legs and tail, it has a pair or two of wings, tied on in various positions, flat, cocked, split, etc.

It is not my intention to give any instruction in the art of fly-tying, nor do I deem it at all experlient, for it is an art that can not be taught by written directions, without the aid of explanatory cuts and diagrams, and even then 
in but a moderate degree. The best way for one to olptain an insight into the mysteries of the art, is to carefully dissect and take apart the flies of the best makers, for in the taking apart one can acquire more or less of the modus operandi of the putting together.

The most approved hooks for bass-flies are the Sproat, O'Shaughnessy, Dublin Limerick, Cork Shape Limerick, and hollow point Limerick. I consider them best in the order named, though the O'Shaughnessy is thought by many to be the best. It is the same in all respects as the Dublin Limerick, except that it is a little heavier in wire, and it differs from the Sproat only in the barb, the latter having a shorter barb, with the point straight, or pointing toward the extreme end of the shank, forming a true central-draught hook. The barb of the O'Shaughnessy is a little longer, and the point is turned slightly outward. But any of these hooks will give good satisfaction.

The most suitable sizes, for bas flies are Nos. 2, 3, 4 and 5 , the last being the smallest that should be used under ordinary circumstances, though, for the smallest flies, Nos. 6 and 7 may be employed. These numbers apply to all of the hooks named above.

Flies may be tied on a silk-worm gut snell sereral inches in length, or may have simply a small, short gutloop. Those with loops can be used as "stretchers" or tail flies; but when used as "droppers" or bob flies, they must be attached to the leader by a short length of gut, say three or four inches long.

Many trout flies are used, as stated, and with good effect in black bass fishing, for really the form and color of the fly does not seem to make much difference with the bass; he does not seem so "fastidious," as it is termed, in his choice of flies. Inost of the "general" trout flies are taken as patterns for bass flies, as the coachmen, professor, 
soldier, grizzly king, Montreal, queen of the water, king of the water, etc., and all of the "hackles."

As every angler will become partial, sooner or later, to certain flies, and adopt them as favorites to the exclusion of others, I deem it unnecessary to allude to but few, except in a general way; and those that I shall particularize are such as I have used many times with most gratifying results.

I have had more uniform success, day in and day out, with the black, brown, red, yellow, and gray hackles, than with the winged flies; though some of the latter I have cmployed with excellent success for high or rough waters, and those with light-colored or white wings can not be surpassed for twilight fishing, or for very gloomy days.

There are flies and flies. Nearly every angler has his farorities, both in general and special flies. Tery often the preference is purely fanciful, but it is a pardonable weakness, to which we are all more or less prone; and then it can not do much harm. for I helieve that, in most instances, we are more choice in the matter than the fish themselves. The facts are, as before stated. that, when fish are rising freely, almost any fly will kill; but when they are shy and diffident, it is only flies of certain colors, or combinations of colors, and skillfully cast, that seem to induce a rise. Perhaps, after all, it is the manner of offering, rather than its peculiar features, that renders a particular fly more killing than others at certain times.

But that there are some flies that are more generally and uniformly killing, day in and day out, on various waters, is a fact proved by practical experience, and generally admitted by fly-fishers. Among these are notably the coachman, grizzly king, professor, Montreal and the several hackles. These were all originally trout flies, but they answer as good a purpose for the black bass when made of the proper 
size, which is not much larger, if any, than the ordinary trout fly.

We really do not know, exactly, what color or combination of colors, or just what form or size, they prefer. Sometimes they will take any thing made of feathers, tinsel, silk, or wool, or a bit of rag, and of any known color; at other times they will notice only certain colors or sizes, and at still other times they will rise to nothing in the semblance of an artificial fly. Then, again, a fly or flies that are killing on some waters are comparatively useless on others.

If we knew the "particular vanity" of the black bass in color or colors, or if he is color-blind, just what form or size is most tempting, we should have an easy task. Experience and observation teach us, however, that the black bass, like most other game-fishes, seems to have a penchant for red, yellow, brown and black, and at times gray and green, and many artificial flies embody one or more of these colors in their construction, and they are usually killing flies.

Perhaps this can be better shown in the following table, where the predominating colors of body, wings and hackle are readily seen:

\begin{tabular}{|c|c|c|c|}
\hline NAME OF FLY. & Body. & Wings. & Hackle. \\
\hline 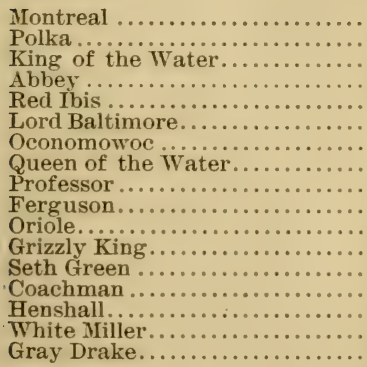 & $\begin{array}{l}\text { Red. } \\
\text { Red. } \\
\text { Red. } \\
\text { Red. } \\
\text { Red. } \\
\text { Yellow. } \\
\text { Yellow. } \\
\text { Yellow. } \\
\text { Yellow. } \\
\text { Yellow. } \\
\text { Black. } \\
\text { Green. } \\
\text { Green. } \\
\text { Harl. } \\
\text { Harl. } \\
\text { White. } \\
\text { Gray. }\end{array}$ & $\begin{array}{l}\text { Brown. } \\
\text { Gray. } \\
\text { Gray. } \\
\text { Gray. } \\
\text { Red. } \\
\text { Black. } \\
\text { Brown. } \\
\text { Gray. } \\
\text { Gray. } \\
\text { Brown. } \\
\text { Yellow. } \\
\text { Gray. } \\
\text { Brown. } \\
\text { White. } \\
\text { Gray. } \\
\text { White. } \\
\text { Gray. }\end{array}$ & $\begin{array}{l}\text { Red. } \\
\text { Red. } \\
\text { Red. } \\
\text { Red. - } \\
\text { Red. } \\
\text { Black. } \\
\text { Dun. } \\
\text { Red. } \\
\text { Brown. } \\
\text { Green. } \\
\text { Black. } \\
\text { Gray. } \\
\text { Red. } \\
\text { Brown. } \\
\text { White. } \\
\text { White. } \\
\text { White. }\end{array}$ \\
\hline
\end{tabular}


The foregoing list embraces all of the flies that I use in black bass fishing, except the red, black, brown, gray, and yellow hackles. The last four in the table are especially useful on dark days, or toward evening.

Most of the flies in the table are general farorites, and in my own hands have all proved very killing. I merely mention them, to the exclusion of others, as a general guide, for each angler will soon adopt a few flies for his own fishing, none of which may have been mentioned above, but he will nevertheless contimue to use them, and swear by them on all occasions; and this is one of the glorious privileges of the art of angling.

As a father naturally thinks his own children the hest, smartest, and handsomest. I may be pardoned for placing in the above list - and strongly recommending as general flies - my polka, oriole, Oconomowoc. and Henshall, leaving to others the praise or condemnation due them. The formulas for their construction are as follows:

Polka.-Boly. scarlet, with gold twist; hackle, red; wings, black with white spots (guinea fowl); tail, brown and white, mixed.

Oriole.-Boly, black, with gold tinsel; hackle, black; wings, orange or yellow; tail, black and yellow, mixed.

Oconomouoc.-Body, creamy-yellow; hackle, white and dun (hairs from deer's tail) ; tail, ginger ; wings, cinnamon (woodeock).

IIenshall.-Body, peacock harl; hackle, white hairs from deer's tail; wings. gray (dove); tail, two fibers (green) from peacock's tail-feather.

The Lord Baltimore fly originated with Prof. Alfred MI. Mayer, of the Sterens Institute of Technolngy. Hoboken, New Jersey. Its formula is as follows:

Lord Baltimore.- Body, orange; hackle, tail and wings, black, with small upper wings of jungle-cock. 
Professor Mayer and I, being natives of Baltimore, and knowing that black and yellow formed a good and taking combination in an artificial fly, each designed, unknown to the other, a fly to embody these colors; and as they are the heraldic colors of the State of Maryland, and were the heraldic colors of Lord Baltimore, Professor Mayer aptly named his trout fly, "Lord Baltimore;" while I designated my black bass fly, the "oriole," from the Baltimore oriole, or hanging bird, which beautiful songster was named in honor of Lord Baltimore, as its colors were the same as his own - black and orange.

The following fly is one of my own designs, and at times is very killing. It is constructed entirely of metallic colors, and I give its formula in order that any one feeling an interest in it may try it:

Golden Dustman.-Body, bronze (peacock harl); hackle, golden yellow; wings, bronze (wild turkey); tail, fibers from the crest of golden pheasant.

Abbey \& Imbrie have patented and manufacture what they call the "fluttering fly." It is made in the same patterns and in the same manner as the conventional fly, except that the hook is reversed; that is, the tail of the fly is at the end of the shank, while the head is near the bend of the hook, or opposite to the point.

Some of the hest flies for black bass that I have seen are tied by George H. Burtis, Worcester, Mass. He uses the best material to be obtained, and his flies are at once artistic, beautiful and practical.

Charles F. Orris has long been farorably known for his excellent bass flies, and he sustains his well-earned reputation for careful and superior work, and is indorsed by hundreds of our best anglers.

The following is a list of flies that have been employed 
for bass fishing, and their construction does not differ much from that described by John Gay two centuries ago:

"To frame the little animal, provide

All the gay hues that wait on female pride;

Let nature guide thee. Sometimes golden wire The shining bellies of the fly require;

The peacock's plumes thy tackle must not fail, Nor the dear purchase of the sable's tail.

Each gaudy bird some slender tribute brings, And lends the growing insect proper wings:

Silks of all colors must their aid impart, And every fur promote the fisher's art."

Professor:-Body, yellow; hackle (legs), golden brown; tail, scarlet ibis; wings, yellow, mottled.

Queen of the Water.-Body, dark yellow, gold tinsel; hackle, red; wings, mallard, mottled.

Grizzly King.-Body, green; hackle, gray; tail, red; wings, pin-tail duck or mallard.

Soldier.-Body, scarlet; hackle, red; wings, gray.

Montreal.-Body, red; hackle, scarlet; wings, wild turkey.

Governor Atrord.-Body, peacock harl; hackle, red; tail, red ilbis; under wings, brown, upper wings, drab.

Seth Green.-Body, green, with yellow stripe; hackle, red; wings, brown (woodcock).

Abbey.-Body, scarlet. gold twist; hackle, red; tail, golden pheasant; wings, pin-tail duck.

Ferguson.-Body, yellow, gold twist; hackle, green; tail, peacock. yellow and scarlet; wings, yellow and scarlet, and wild turkey.

Kingdom.-Body, white, striped with green; hackle, red; wings, woodcock (brown). 
Gold Spinner.- Body, orange, gold tinsel; hackle, light red; wings, gray.

Captain.-Body, gray, and peacock harl; hackle, red; tail, scarlet, green and wood-duck; wings, gray.

Ibis._-Body, scarlet mohair, silver twist; tail, hackle, and wings of the red ibis.

The following flies are also good ones, some being great favorites with certain anglers:

Reuben Wood.-Body, white, with red head; hackle, brown; wings and tail, rayed feathers of mallard.

Dr. Fowler.-Body, white; tail, scarlet; hackle, scarlet and white; wings, red ibis and white.

Green Dralie.-Body, white, ribbed with black; hackle, ginger; tail; dark; wings, mottled green and yellow.

Gray Drake.-Body, dark gray; hackle, gray; tail, dark; wings, gray (mallard).

Brown Drake.-Body, golden brown; hackle, brown; tail, dark brown; wings, golden brown.

IIolberton.-Body, orange, gold tinsel; hackle, peacock harl and scarlet; tail, wood-duck and scarlet; under wings, red ibis and yellow; upper wings, peacock and wood-duck.

Shoemalier.-Body, alternate rings of salmon and gray; hackle, light red; tail, wood-duck; wings, mallard (gray).

Superior.-Body, dark claret; hackle, brown; tail, blue macaw; wings, wild turkey.

General Ilooker.-Body, alternate yellow and green rings; hackle, red; tail, wood-duck; wings, tail feathers of ruffed grouse.

Quaker.-Borly, gray; hackle, yellow; wings, horned owl's wing.

King of the Water.- Body, scarlet, gold tinsel; hackle, red; wings, bright mottled, mallard. 

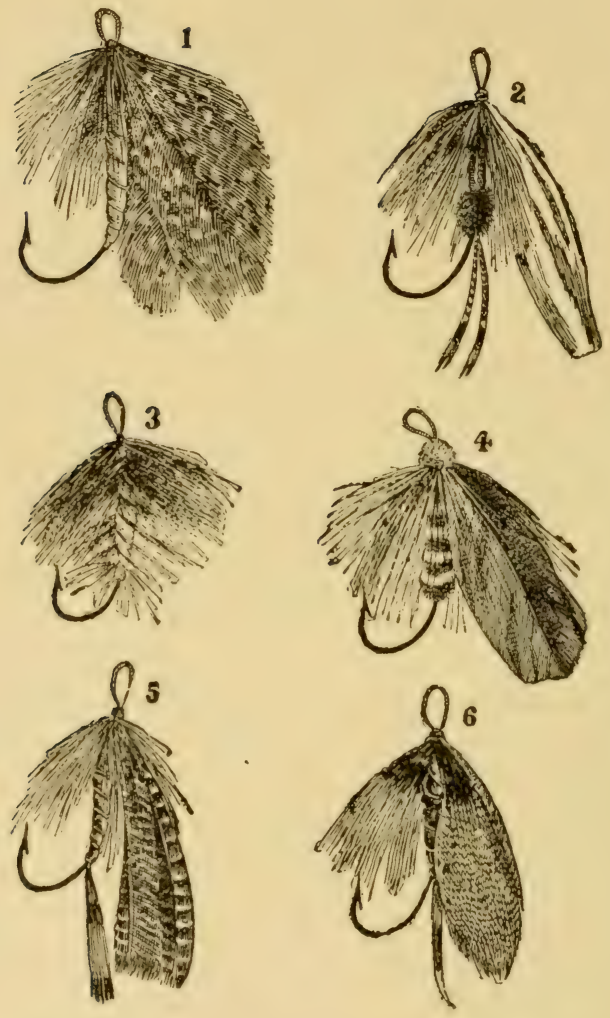

No. 1. Polka.

No. 4. Bumble Bee.
No. 2, Coachman. No. 5. Abbey.
No, 3. Hackle.

No. 6. Grizzly King. 
McLeod.- Body, emerald green, with gold twist; tag, yellow and red floss; wings, dark mottled brown; tail, green drake, with red ibis and mottled yellow; hackle, yellow; antennæ or feelers, scarlet.

Imperial.-Body, red, with silver twist; tag, silver; tail (whisk), red and white; hackle, black and white; wings, large, grayish white, bordered with black; feelers, scarlet.

Green and Gold.-Body, emerald green, gold twist; tag, scarlet; tail, white and read; hackle, yellow; wings, olive green.

La Belle.-Body, pearly blue, silver twist; tag, red and gold; hackle, blue; wings, pure white; tail, red and white.

Royal Coachman.-Body, scarlet, and peacock harl; tail, pin-tail duck; hackle, brown; wings, white.

The White Moths, or Millers, are excellent flies for moonlight evenings, or at dusk. They may be pure white, or all white with yellow body, or all white with gray wings. The bodies should be made full and fluffy.

The hackles and palmers are made with bodies of various hues, as black, green, red, or yellow, or peacock harl, with either black, red, brown, yellow or gray legs. A pure white hackle is rery killing about dark. A most excellent hackle is made from the hairs of a deer's tail, somewhat in the fashion of the "bob," so extensively used in Florida and Texas.

The three "typical" hackles of Mr. H. CholmondelyPennell, and which he recommends to the exclusion of all other flies, are described as follows:

Green.-Dark green body; very dark green hackle for both legs and whisk.

Broun.- Body, dark orange; fiery or cinnamon-brown hackle for legs and whisk. 
Yellow.-Body, golden yellow; darkish golden-olive hackle for legs and whisk.

As I have described quite enough for the beginner, and, perhaps, too many, I will only allude to some by name, which may often be found equal to the above, and, for some waters, superior:

Bumble bee, jungle cock, Hoskins, California, moosehead, widow, academy, blue jay, Page, yellow sally, blue and drab, pheasant, raven, claret, tippulium, Davis, Tanner, white and green, motley, premier, black and tan, black and gold, purple bass, fire-fly, little egg. gray coflin, brown coflin, sand-fly, stone-fly, hawthorn, dark mackerel, etc.

It will be seen that the angler has quite an extensive list to choose from, for most of the flies named are kept in stock by our best dealers. As a rule, the smallest bass flies should be selected for general fishing; and those of subdued tints will be found the most successful, saving on the exceptional occasions already referred to. As has been mentioned, most of the flies named are patterned after trout flies of the same names; and, while some of the latter are large enough, quite a number are too small, and must be enlarged somewhat for bass flies.

But there are flies, and enough, to suit those of every taste, eren should the angler he so fastidious and dainty as "Ye Sunberry Fisher," as described by "Punch:"

"Ye Sunberrye fysher has flies of all feathers, For all sorts of seasons, in all sorts of weathers.

Flies when ye Springtide is blustrie and showerie, Flies when ye Summer is grassie and bowerie, Flies when ye Autumn is golden and grainie, For hot weather, cold weather, mistie, or rainie.

Red-spinner, palmer, black peacock and gray, Yellow dun, golden dun, Mareh brown, and May, Sand-fly and stone-fly, and alder and gnat, Black midge and marlow bug - all round his hat." 
The Japanese are, perhaps, the most artistic and expert fly-tyers in the world. Some of their creations in this line are indeed marvelous. They excel particularly in the smallest flies, which have short, plump bodies, and hackles that stand nearly at right angles to the body. They are mostly red, brown, black and gray, are tied on needlepointed, barbless hooks, and with a minute gilt head; they are remarkably life-like when cast on the water. They also tie flies on barbed hooks, and with wings, but mostly for export.

At the Chicago Columbian Exposition I was much impressed with the display of artificial flies in the Japanese exhibit in my department. One day, as I was judging their exhibit of fishing tackle, accompanied by the members of the jury of award and a number of Japanese officials, I called their attention to a case of artificial flies that were tied in bunches and hung in front of the exhibit. The case was open to inspection at all times, not being covered with glass. I remarked:

"Now, here are some flies that are very life-like. They look as if one could squeeze the juice out of them; as if they might take wing and fly away." At that I lifted up a bunch with my lead-pencil, when, lo and behold, one flew out from the bunch, balanced itself on its wings a moment, and then took an upward flight, disappearing in the skylight of the building. My auditors stood open-mouthed with astonishment, thinking, doubtless, that I had performed some trick of legerdemain. I was startled for a moment, myself. until I saw that it was a moth that had been having a feast of feathers while hiding behind the bunch of flies. 


\section{CHAPTER XV.}

\section{ARTIFICIAL BAITS.}

"And therefore I have, which I will show to you. an artificial minnow that will catch trout as well as an artificial fly; and it was made by a handsome woman that had a fine hand, and a live minnow lying by her."--IzAAK WALTON.

Prob.risy in no direction has there been more ingenuity displayed than in the production of artificial baits, such as trolling spoons, spimner's, propellers and artificial minnows, frogs, crustacea, insects and nondescripts.

\section{Trolling-Bitts - Spoon-Batts.}

The most commonly-user! artificial bait for black bass is the spoon-bait or trolling-spoon. It is now made of all shapes, and many sizes; but all are made upon the same general principle, and are merely variations of the original trolling-spoon, which was fashioned from the bowl of a spoon, a single hook being soldered to one end, and a hole drilled in the other end for attaching the line.

By trailing or trolling such a spoon at the end of a line from a moving hoat, it revolves gracefully beneath the surface of the water, the burnished surfaces flashing at each revolution, and proves quite an effective lure.

The changes that have been rung upon the original oval metal spoon, with a single hook, have been, to say the least, remarkable; and it is, indeed, surprising to see the number of forms that have been evolved from that simple implement. Every conceivable shape into which the old spoon could be cut, bent or twisted, and still have it revolve, has been resorted to; it has been fluted, hammered 
and corrugated; grooved, ribbed and perforated; embossed, painted and nickel-plated; and doubled and trebled, and made to spin around floats and balls and metal minnows and flies, until the brain begins to whirl, and the eyes become dazed in their contemplation. Some are fearfully and wonderfully made, and are the most cruel and murderous-looking instruments of torture ever devised for the use of the followers of the meek and gentle Walton.

There is nothing better than the original spoon bowl with a single hook. The double and triple hooks, usually attached to the modern spoons, are liable to be crushed and broken by the jaws of a large fish, if hooked in a position favorable to this contingency.

Why do manufacturers persist in affixing the triple hook, or triangle, to trolling-spoons, when a single hook is so much more efficient, preferable and humane? There is nothing so effective as the single hook for any kind of fishing. The fish is more certain of being hooked, more certain of being landed, and if he breaks away does not have his mouth so torn and lacerated as by the villainous triple hook or gang. I have found dead bass with the entire premaxillary bone (upper lip and jaw) torn off by these murderous implements. I never see or hear of an angler using or recommending a gang of three or more hooks for trolling the live minnow without setting him down as a pot-fisher; and all humane and genuine anglers - those who love fair play and use light and elegant tackle - should deprecate and discourage the cruel practice.

Trolling-spoons are all made with a concare and a convex surface; the latter surface being brightly polished or burnished, while the former is generally painted, and usually of a red color. They are made of tin or brass, and often plated with nickel, silver or gold; but so long as 
spoon-baits are brightly burnished, it matters not what the material is, for the black bass is not a judge of metals, but will grab at any thing bright and in motion.

The depending hook or hooks may be plain, or dressed with a tuft of feathers or braid, called, by courtesy, a "fly;" but these fanciful additions, while pleasing to the angler's eye, do not enhance the "taking" qualities of the lure, for it is the flashing and glancing of the revolving spoon that attracts the fish, and it can not be made more effective by these ornamental appendages, or, as I have sometimes seen, by the addition of a live minnow, or a strip of fat pork!

One or two brass swivels should always be attached to the spoon-bait or line, to prevent twisting or kinking. Particular attention should be paid to the hooks of trolling-spoons, for many of them are of inferior quality.

The trolling-spoon has its legitimate uses, when it is jopeperly made and judiciously employed. There are situations where the small revolving spoon with a single hook can bre cast with a light rod and still remain within the pale of lexitimate angling: ?ut there is never any excuse for nsing more than a single hook.

As a rule, most persons use spoons too large for black bass, using generally pickerel baits. For the black bass, ihe spoon should be no larger than the bowl of an ordinary sized tea-spoen, for trolling with the hand-line; and when trolling with the rod, they should be still smaller.

I am glad to note that some of our progressive manu. facturers have become convinced that a single hook is better for trolling- and casting-spoons than the triangle or triple-hook, and at the same time more humane. It is a pleasure to me to mention some of them, in this connection, with a description of their wares, for I have long 
contended for the relegation of the triangle, and the adoption of the single hook.

The Andrew B. Hendrix Company make a large line of single-hook lures, which are kept in stock by retail dealers. Their bass flyspoon, though made of polished tin, is very effective either for trolling or

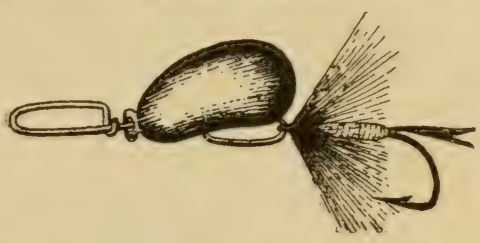
casting, being of the most, suitable size. it is furnished with a steel snap, by which either a naked hook

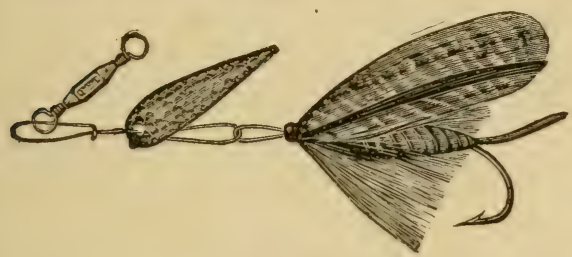
or a fly can be affixed. One with a still smaller spoon, which is nickel or gold plated, is still better for casting. It has a springbrass snap and lorass box-swivel, by which can be attached a Sproat hook or a fly. Another one is the fluted

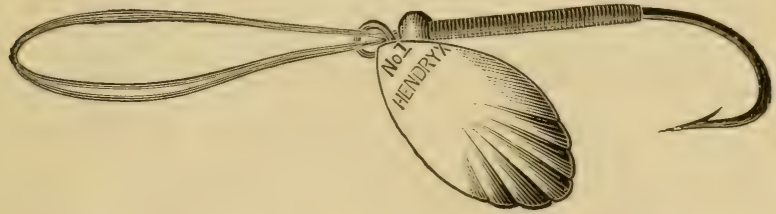

casting-spoon, either nickel plated or enameled in white. It is furnished with a Sproat hook and double gut loop.

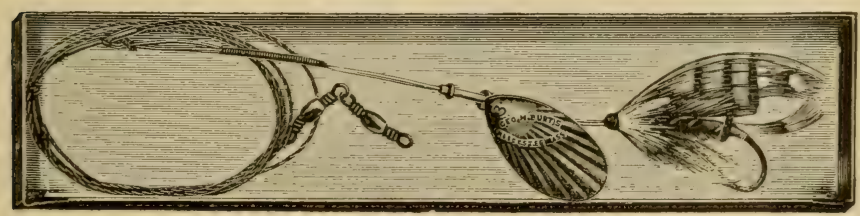


The "Irresistible" single-hook trolling-bait made by George H. Burtis, Worcester, Mass., is an elegant article with a gold-plated spoon, a long reinforced gut snell, and a first-class fly, with two bronze box-swivels and a twisted gut leader. It is shown at the bottom of the precerling page.

John J. Hildebrandt, Logansport, Ind., makes a line of

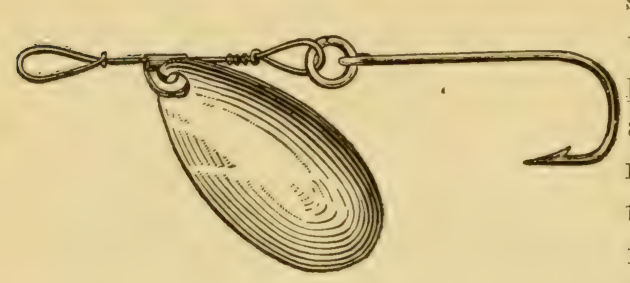

single-hook lures which are very popular with the anglers of the middle west. His trolling-spoon is fitted with a good, serviceable hook, and is a well-made and efficient article. It is made to catch bass and not for show or ornament.

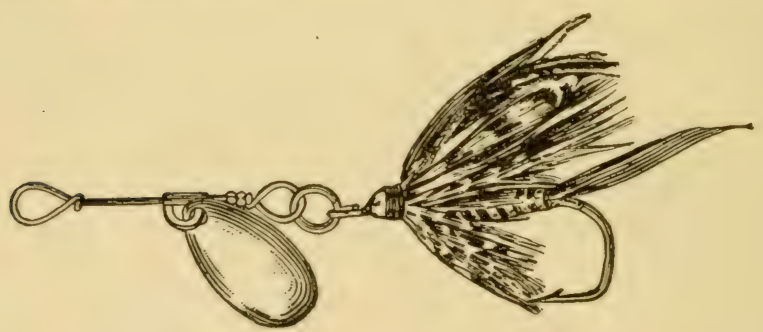

His fly-spoons are likewise practical, substantial lures, as they are made by a practical bass angler. He makes also trolling baits with two spoons, some furnished with deertail flies. It is worthy of note that the flies are attached to the shaft of plated piano wire by small, patented splitrings, so that they can be readily changed. Swivels are not necessary, inasmuch as the baits swim so perfectly that 
the line is not twisted. In playing a fish the blades will reverse so that weeds are not liable to catch on them. 'They show decided improvement in every way. The spoons are

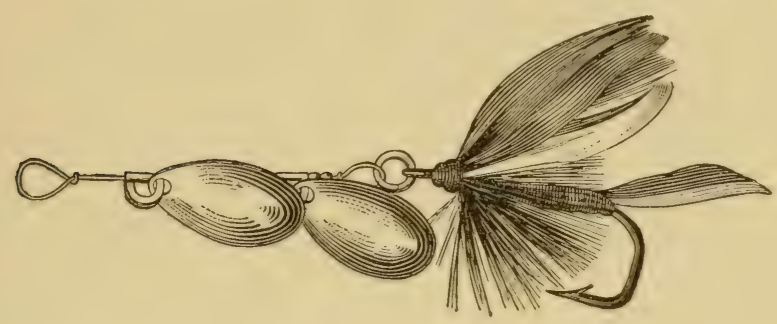

especially neat and of small size, just what I have advocated for years.

Abbey \& Imbric have patented a novel trolling device, with single hook, called the "ghost," made of aluminum, and constructed on entirely new principles. Its rotary motion may be regulated by curving or straightening the fins. It revolves freely upon the slightest motion, and is especially recommended for surface trolling or shallow water. They also furnish single-hook casting and trolling-spoons, and weedless casts.

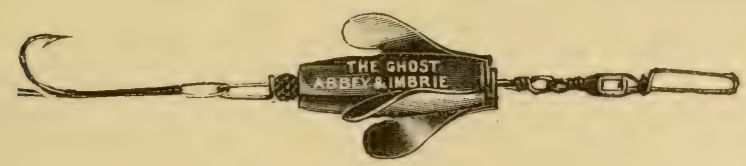

H. R. Stewart \& Co., Chicago, hare patented and manufacture two novelties called the " pilot," and "turn-a-frog." The former has two pair of aluminum wings, at right angles with each other, with a swivel at each end. It is 
designed to regulate the depth at which it is desired to maintain a trolling-spoon or other bait, and is attached at some distance from

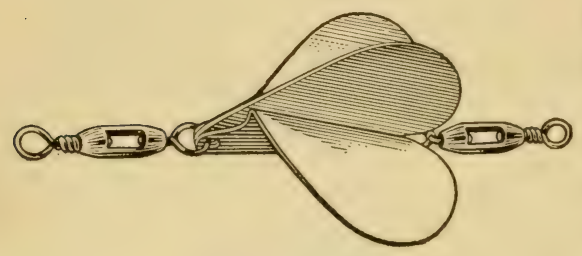
them. When the line is attached to one end it runs near the surface, but by reversing it, it runs deeper, and as it always swims upright

it prevents twisting of the line.

The "turn-a-frog" is also constructed with two pairs of fins, two horizontal and two vertical, and can also be reversed. It is in-

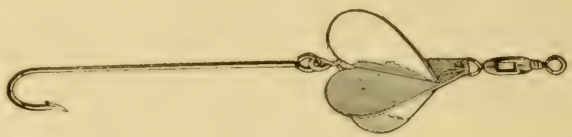
tended to keep a frog or minnow in an mpright position when cast or trolled, and will run deep or shallow as required.

Barnard \& Markham. Jackson. Wich., make the "Burgess weedless spinner," which is quite a unique lure. It consists of a long-

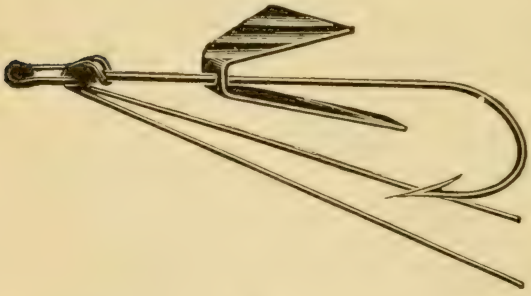
shanked Carlisle hook to which is affixed a spinner of an odd, but effective, shape. It has two wire fenders which precede the hook, thus preventing its eatching in weeds or other obstruction. It is well spolien of by those who have used it. It is designed, especially, for very weedy waters, where it is useless to troll with the ordinary spinners. 
Other trolling-spoons or baits are made in fanciful shapes; also many styles of minnows, propellers, spinners, etc., but they are no better, and many of them not so good as those before mentioned; for the nearer a spinning spoonbait approaches the original spoon, already referred to, the more practical and useful it becomes.

There is nothing in this line more beautiful than the abalone shell spoon; and it will always be a "spoon," for being made of shell it can never be bent or twisted into the fanciful forms of some of the metal ones. It is very effective as a lure, and the smallest sizes are well adapted for the fly-rod in broken waters.

\section{Artificial Minnows.}

Artificial minnows for trolling, spinning, or casting, are made of metal, glass, wood, and rubber, large and small, and gilded, silvered, or painted in attractive ways. Some of them are quite successful as baits, while others are comparatively worthless. They are made both in our own country and in England, and as their numbers, and styles, and forms are constantly increasing, I do not deem it advisable to particularize or give special descriptions. While I have experimented with many of them, I do not employ them in angling for the black bass.

For trolling or spinning, none of them are so effective as the spoon-baits; while for casting, they are not to be compared with the natural minnow, alive or dead. The most effective are made with soft rubber or silk bodies, with propellers, which cause them to spin. The most successful is the "phantom." 
Artificial Insects, Etc.

Artificial insects, as bees, grasshoppers, crickets, beetles, May-flies, dragon-flies, and likewise artificial mice, frogs, crawfish, hegramites, shrimps, worms, ete., are now made which resemble the original creatures very closely. They are to be used in surface fishing, in the same way as artificial flies, and must be lept in constant motion, otherwise the bass soon discover the deception; but if skillfully used, they are sometimes sucessful baits. They certainly have the recommendation of cleanliness and general convenienee as compared with their original prototypes.

Many years ago I was trout fishing on Slate river, the inlet of Gogelic lake, and was returning down stream, liomeward bound on account of a heavy rain. I sat in the bow of the boat casting under the banks on either hand as my boatman paddled noisclesily along. On reaching a wider portion of the stream I observed a field-mouse swimming across, and when it reached the center of the pool a fine trout rose for it, but as he did so, saw me, turned tail and disappeared. I secured the mouse with the dip-net, and upon my arrival at the hotel I imparted what I had seen to a friend who was very anxious to kill a large trout. The next day he repaired to the spot and succeeded in taking it with the mouse; it weighed fully one and a half pounds, and was a good fish for that stream.

\section{The Вов.}

Of all baits or lures used in black bass angling, one of the rudest in structure, the most noncescript in appearance, yet one of the most effective and killing in actual practice, is the "bol)" of the extreme southern states.

It has been in use in Florida for more than a century, 
and was first described by that quaint old naturalist, Bartram, in 1r6t. His description and method of using it, are identical with the "boh" and its use at the present day in Florida, Louisiana, and Texas.

The "bob" is composed of a triple hook, or three hooks tied back to back, and invested with a portion of a deer's tail, in the manner of a large, bushy, hackle, often intermixed with red and white feathers, or strips of scarlet cloth. It forms a tassel or tuft, somewhat similar to the so-called triple-hook "fly" attached to most trollingspoons. A single hook, however, is much to be preferred to the triple-hook. 


\section{CHAPTER XVI.}

\section{NATURAL BAITS.}

"And, good master, tell me what baits more you remember."IZAAK WALTON.

\section{Minnows.}

Aroxt anglers, the term minnow is used to express any small fish used for bait, whether adult fish of certain families, or the young of others. But the term properly belongs to the family CYPRINID.s, which comprises numerous genera, and some of the genera are composed of many species.

The most generally diffused species are Notropis cornulus, the common shiner; semotilus corporalis, the common (hub); IIybopsis lientucliensis, the horned chub, and the steel hack. Campostoma anomalum. The shiner is, by all odds, the best hait for the black loass, being quite silvery, as its name implies, and shows well in the water. It is not so hardy, or long-lived, on the hook, as the chub or steel back; but on account of its white and silvery appearance it is especially desirable for turbid or rough water, and on cloudy or dark dars, though it is, for that matter, a good bait at all times.

The chuls are good bait on lyight days with clear and still water; they have rather tough mouths, endure the hook well, and are rather more lively than shiners, and on these accounts are preferred by many anglers.

The roung of some of the species of Citostonide (suckers), are also very good baits on sunny days, with clear and low water; their tough, leathery, and projecting 
lips are well adapted for the hook. They are quite hardy and lively.

The young of Perca americana (yellow perch), are excellent baits on ponds and lakes, early or late in the season, especially if the spinous dorsal fin be clipped off with a sharp knife, or a pair of scissors. They show well in the watcr, and often prove an attractive lure during the seasons mentioned.

As a rule, good-sized minnows should be employed, say from three to four inches long. The large minnows are livelier, more hardy, and live much longer on the hook than the small ones. A half-pound bass will take the largest minnow as easily and as readily as the smallest one, so there is no fear of using minnows too large. It is true, that at times, the largest bass seem to take to the smallest minnows, but on these exceptional occasions they are off their feed, to a certain extent, for, usually, the largest bass takes the largest minnows.

In baiting with the minnow, the hook should be entered through the lower lip and out through the nostril; if this is carefully done, the minnow will live a comparatively long time. Sometimes, with small minnows, the hook is passed out through the socket of the eye; but this should only be done with dead minnows. Another excellent way, especially with large minnows, is to pass the hook through both lips, the lower one first, and out through the upper one. When minnows are hooked in either of these ways, a dead one is often as good as a live one, for the moving of the line causes them to more in a natural manner. Where the water is without a current, as on ponds or lakes, and where the minnows are quite small, they may he, for still fishing, but under no other circumstances, hooked just 
back of the dorsal fin, and just above the backbone. But in hooking a minnow in this way, the angler should bear in mind the injunction of Father Izaak, in reference to hooking the live frog: use him as though you loved him. Chubs and suckers should always be hooked through the lips, which are comparatively tough.

The angler can not be too careful of his minnows. The water in the bucket should be frequently changed, without waiting for them to appear at the surface to breathe - the usually accepted indication to change the water - for their vitality and strength are already impaired when this takes place, and many of them can not be revived afterward. When available, especially in very hot weather, a piece of ice should be placed in, the minnow pail, and covered with a woolen cloth. A little salt, added to the water in the pail. is very beneficial and adds to the preservation of minnows.

It is a good plan, when practicable, to use two minnowbuckets, one of which, containing most of the minnows as a reserve, should be sunk in the water, and a few minnows taken out, as needed, for the bucket in use. In this way, the entire stock can be utilized in good condition.

In carrying minnows to any distance, they should not be too much crowded in the pail; fifty minnows is enough for a five-gallon bucket. When more than this number is required, additional pails should be provided. A handful of water-weeds in the pail will prevent the minnows from being so much injured, as they otherwise would be, when conveyed over rough roads.

When it is not practicable to allow of a frequent charging of the water. the latter may be oxygenized or aerated by inserting a rubler, or other tube, well toward the bottom of the pail, and pumping air through it by means of 
a rubber bulb, such as is attached to a pump-syringe. It is worse than useless to blow through such a tube with the mouth, for the breath, being deprived of its oxygen in the lungs, carbonic acid gas takes its place, which is poisonous to the minnows; yet I have frequently seen this done by individuals, who erroneously supposed that they were freshening the water, because of the numerous buhbles produced. A still better method of aerating the water is to dip it up with a cup, and pour back again from a height of one or two feet.

Dead minnows are now preserved and put up in small bottles for the great convenience of the angler. They answer every purpose, as a dead minnow is just as good as a live one if kept in constant motion. I have seen the minnows thus prepared by The Curtis-King Company, Milwaukee, Wis. They are mostly shiners about three inches long. As minnows are becoming scarce in some sections of the country, this enterprise is greatly to be commended, both as a boon to the angler. and in mercy to the minnow. King's prepared shiner bait is now kept in stock

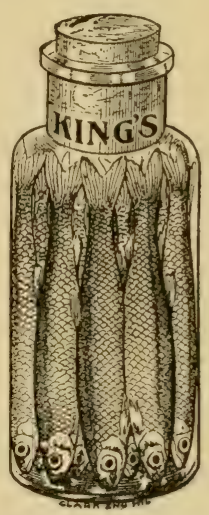
by Abbey \& Imbrie and other dealers.

\section{The Helgramite.}

The larva of the horned corydalis (Corydalis cornuta), an insect belonging to the order Neuroptera, is variously called "helgramite," "dobson," "grampus," “dobsell," "helion," "kill-clevil," "crawler," and other eupho- 


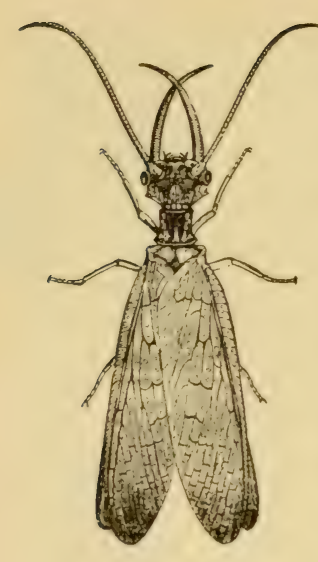

nious names. The male of the perfect, winged-insect has long antennæ, or horns, from which its specific and common names are derived.

It exists for several years in the larval state, when it is generally known as the "helgramite," being a curious, flattened, and, to most persons, a repulsive-looking worm, growing to a length of two or three inches, and about a half inch in width. It has a head and pincers resembling, somewhat, those of a heetle: has six legs along the thorax; while the body is composed of a number of rings. to which are attached fringes bearing some likeness to small legs; the body terminates in two short appendages, or tails, on each of which are two small hooks. The color is a dark, dirty, brown.

The helgramite, by means of its hooks and pincers, (dinge readily and tenaciously to different objects, and hides securely under rocks, boulders, driftwood, logs, etc., even in swift-running streams. They may be found clinging to the decaying timbers of old dams and bridges, and in the crevices of submerged stone-work at these places. They are found on the "riffles" of streams, under the boulders and flat stones, and may be taken in these situations with the minnow-net, by stretching the latter across the foot of the riffle; when the stones above the net are turned over, the helgramite, being thus disturbed, curls himself into a

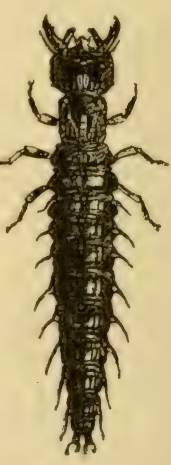
ball drifts into the net. 
They can be found, in fact, hiding under almost any submerged object in the shallow portions of streams. They feed upon decaying woorl and regetation, and other sulsstances. They can be kept alive for almost any length of time, in a ressel half filled with wet pisces of rotten wood, and damp aquatic regetation. In this way the angler can always have a ready supply of bait on hand.

The helgramite is hooked by inserting the point of the hook under the cap or shell that covers the neck, from behind forward, and bringing it through next to the head. It is a capital bait for the black bass, especially when the lass are found on the riffles or rapids, and in shallow water.

\section{The Cratwrish.}

The crawfish (Cambarus), sometimes called crayfish and crab, is, in some localities, and at certain seasons, a good bait, especially when casting its shell, when it is called a "peeler" or a "shedder." The crawfish exists wherever the black bass is found, in greater or less quantities. In waters where it is very abundant it forms an excellent and killing bait.

"Distinct species live in the mountain streams and in the springs at their sources. Some frequent the marshes of the lowlands (both the fresh and salt marshes), either near the streams, or arljacent to the bays. sounds, or ocean. Some occur beneath stones in rivers, creeks, or branches; in the muddy basis: beneath stones in the rapids; among grass and weeds in more quiet places. and in coves; under shelving grassy banks: in holes at the bottom of ponds, lakes, dams, and mill-races. Others hore holes in the meadows, or eren in the hill-tops near water; and in bringing up the mud and clay from their tube-like holes, pile it as a chimney at the entrance. These species at 
particular times place a plug of clay in the orifice of the chimney and seal themselves in for a certain length of time. Still others reside in the drains and mud of the rice-fields and plantations of the south, and sometimes hurrow through the embankments, allowing the water to flood the region."

The crawfish is used as a bait for the black bass only in still-fishing. when it serres a good purpose. In its usual state it should be hooked through the tail, but " softcraws" or "peeders" may le hooked through the head or body. They may be liept alive a long time in damp aquatic grass, moss, or weeds.

\section{Grassioppers and Crickets.}

Grashoppers and crickets are at timesery taking baits. They should be nsed als surface baits entirely, and should be employed only when a brisk breege is blowing, and on the winclward sicle of the water; for it is at such timess that they are blown into the water, and the bass are then on the look out for them. The water, also, being brokeni into ripples by the brese. whances the angler's chances of suceess. These inserets should be hookert through the upper fart of the thorax or borly, small hooks being used.

\section{Frogs.}

On marshy streams and ponds. young frogs are often used for baits, with good sucers, in still-fishing. They may be hooked through the lips, or through the skin of the back. They should he of small size, and kept in pretty constant motion, an they are inclined to bury themselves in the mud, or hicke uncler stones. on the bottom, or crawl out mpon oljects on the surface, if left too long to their own devices. 
Salt-water shrimps, when they can be procured, are good baits for black bass, alive or pickled, that is, preserved in salt or strong brine.

I have seen black bass caught with cut bait, and even the humble "wum;" but the angler who is reduced to such serere straits, is more to be pitied than envied.

Frog-casting with a very short rod, five or six feet long, is now practicer! by some anglers, casting overhead, as with the artificial fly. It is a method well adapted for very weedy waters. 


\section{CHAPTER XVII.}

\section{MISCELLANEOUS IMPLEMENTS.}

"My rod and my line, my float and my lead, My hook and my plummet, my whetstone and knife, My basket, my baits, both living and dead, My net and my meat, for that is the chief: Then I must have thread, and hairs green and small, With mine angling-purse, and so you have all."

- IzaAK Walton.

Trre list of miscellaneous implements is constantly being added to, to meet the wants or requirements of anglers. It is not only interesting. but surprising, upon looking over the catalognes of our large dealers, to observe the improvements and inventions that are being made, each season, in this department. Fvery thing that can be devised or thought of to increase the angler's pleasure or comfort is put into practical shape.

\section{The Fly-Book.}

Among the necessary adjuncts to the fly-fishers's outfit is the fly-book, whose pages, well-filled, are more interesting to the angler than the best written pages of classic lore, poetry, or fiction. Fly-books are now mate of many patterns and sizes, and of various grades of quality and material. They are constructed of calf-skin, pig-skin, moroceo, or russia-leather, with parchment leares for holding the flies. Those with metal-clip, for keeping the flies separate and at full length. are the best and most satisfactory, for obvious reasons. They are made in rari- 
ous lengths, from five to seven inches; and of a capacity for holding from three dozen to a gross of flies.

Eicry manufacturer has patented at least one fly-book, and some of them, two or three; and where there is so much competition there is sure to be production of good articles. It is really hard to choose between those now made, and the choice must be left entirely to the angler's taste or fancy as to the different methods of securing the fies, and also as to details of construction and finish.

One of the most recently improved fly-books is the "Monarch," made by William Mills \& Son, New York. It is made in several styles of leather, and of varying capacity, holding from two to eight dozen flies, and is of several sizes. Quite a novel and useful feature is a transparent celluloid pocket to each leaf of the book, in which can be placed casts, leaders or eyed flies, and which are visible without removal from the pockets. It has the

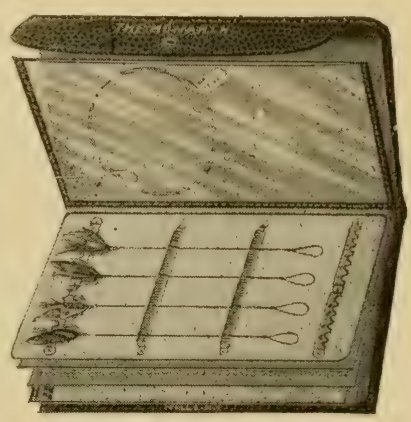
usual metal scalloped band at the top and bottom of each page for the hooks of snelled flies, and two rows of spiral springs for holding the snells secure and apart.

Other good fly-books are made by The Thos. H. Chubb Rod Co., Abbey \& Imbrie, Thomas J. Conroy, and Malcolm A. Shipley. I have used fly-books made by these parties, and all are to be commended, in the best grades, for workmanship, durability and convenience. 


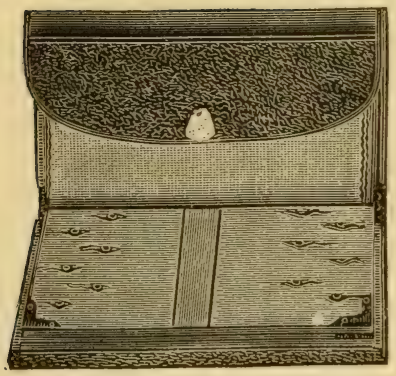

The fly-books of Charles F. Orvis have waterproof and mildewproof leaves. They are made in several sizes and styles. They have improved metal clips and a parchment band for keeping the snells in position. Their eapacity is from four dozen to a gross of flies.

\section{Fly and Leader Boxes.}

A new article is a combined fly and leater lonx of aluminum introduced by The 'T. II. Chubb Rod C'o., which has

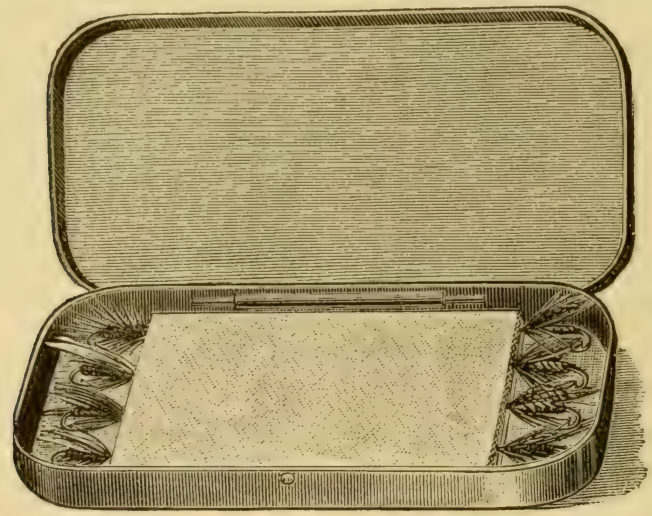

an aluminum coml, at each end for securing snelled flies. The snells, together with leaders, are covered by felt leaves, which are kept soft and pliable by the moist felt. 
Abbey \& Imbrie furnish the "De Witt" fly and leadme box similar to the alose. It is mate of aluminmm with aluminum eoml) partitions. and has three pieces of thick felt. It is quite moderate in price.

An excellent fly-case for eyed flies is made by Charles F. Orvis. It has cork strips to which the flies are firmly affixed, and which. are firmly held in position by metal on three sides. It is well made and sells for a moderate price.

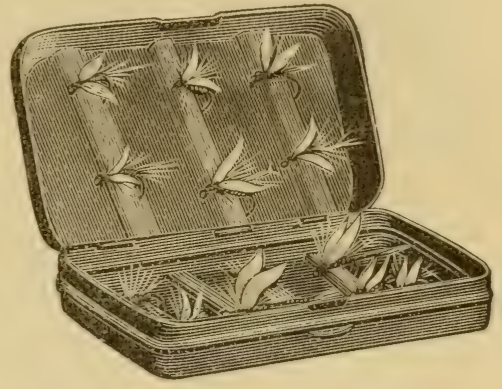

Abbey of Imbrie furnish a metal learler-box, the " Hamil-

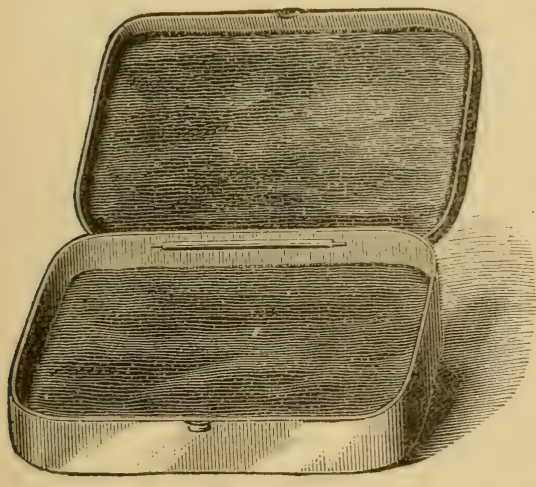
ton," which is fitted with felt leaves for keeping leaders moist. It is of a convenient size for the pocket, with round corners. No fiy-fisher should be without a leader-box of this kind. It saves soaking leaders before beginning his fishing, or the more tedious process of rubbing them with India rubber. thereby causing rexatious delar. There is nothing handier than a good tackle-look made of good leather, in the bellows or accordeon style, so that like an omnibus it is never full. It should have half a 


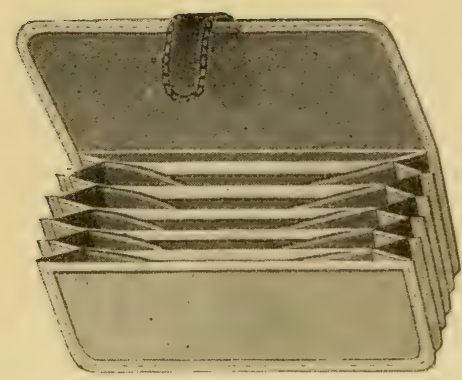

dozen pockets for leaders and snelled hooks, with small, supplementary corner pockets for loose hooks sinkers, swivels, spoons, etc. Where looped leaders, double-looped snells and short-looped flies, or eyedhook flies are used, it is just the article for holding the surplus stock. It should be closed by a long and stout leather strap and flat loops.

\section{Creel, or Fish-Bastet.}

For fly-fishing, or hait-fishing, when watling a stream or fishing from the hank, a creet is very useful and convenient for holding the angler's eatch. Fish are preserved in much better shape, condition and appearance by its use, and it is altogether more satisfactory than the shiftless way of "stringing" the bass, and allowing them to become water-soaked and flabby, by immersing the "string" in the warm and shallow water near the shore, or even by "towing" them after the angler, if wading.

For black bass, the largest trout creels will answer every purpose; say Nos. 3 or $t$, having a capacity of twenty or twenty-five pounds. The shoulder-strap should be leather or webbing, with a shoulder-pad, to prevent cutting or bruising the shoulder.

Fish-baskets or creels should always be well washed, and 
carefully dried after use, to keep them clean and sweet. When washing them, a little carbonate of soda or carbolic acid should be added to the water to destroy the " ancient and fish-like smell."

The best and safest basket sling is like the one furnished by William Mills \& Son, which consists of a broad webbing band to go orer the left shoulder, and a leather waist strap fastened with a snap-hook, by means of which it can be

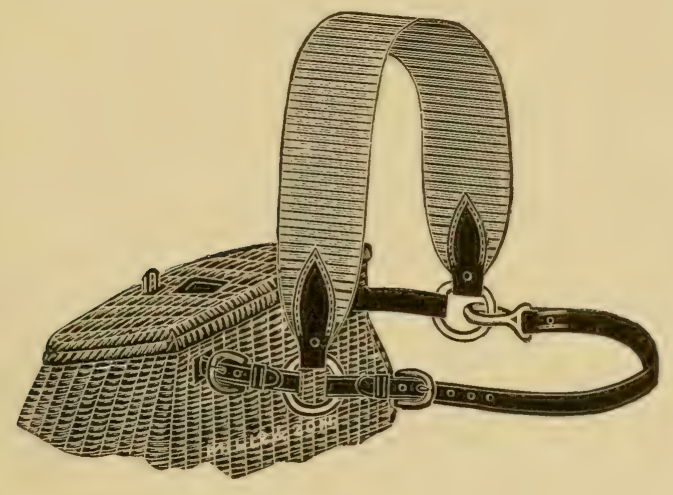

instantly detached and the basket removed, shouid the angler fall into deep water. It is much handier than the old plan of slinging the basket from the right shoulder, as the right arm is left entirely free for casting.

\section{LANDING-NETS.}

There is no reason why the angler can not now be suited in landing-nets, for they are made in every style, from the 
simple wooden-bowed net to the more elaborate and portable net-frames of whalebone, steel and brass.

For boat fishing, the landing-net should have a long handle, which is hest when made in two pieces. with a strong brass ferrule joint. It should be as light as possible, and on this account hambon cane is the very best material for the handle. 'The rim or ring should be ten or twelro inches in diameter. of brass, solid or collapsing; the latter are the most portable and convenient, and are made with one or more hinge joints. The net should be deep, and of a tolerably coarse mesh; linen is the most durable material, though cotton will answer.

For fishing from the hank, or for wading the stream, a short-handled trout net is to be preforred, as it is more easily carried and answers every purpose better than the long-handled net. Those with oval. wooden rims are the lightest, and are as good as any. The long-handled net will answer here by using but one joint of the handle. There should he a hlunt hook, or rimg, at the end of the handle for attaching to the erece-strap). sn as to leave both hands free for casting, and playing the fish.

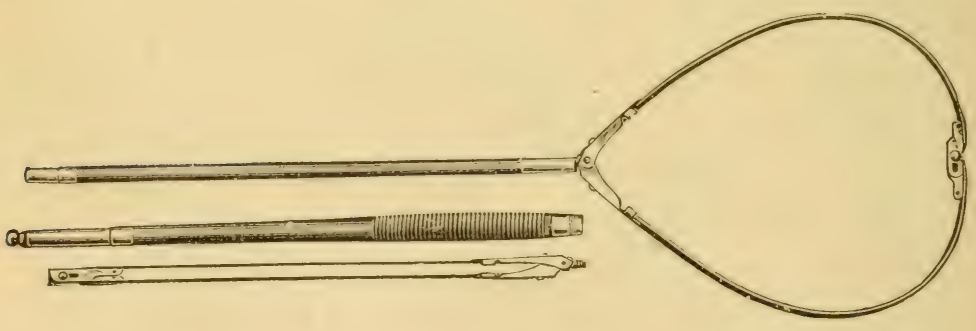

The "Harrimac" brass collapsing net ring made by i. F. Meissellach \& Brother is constructed on the samr 
plan, with lock joint, as the expensive English whalebone collapsing net-ring. An adrantage of this ring is that the net can be left on when folded. The "I-D-L" short-handled net ring is made on the same plan by the same firm. It is coated with rubber enamel, and has a rubber elastic cord by

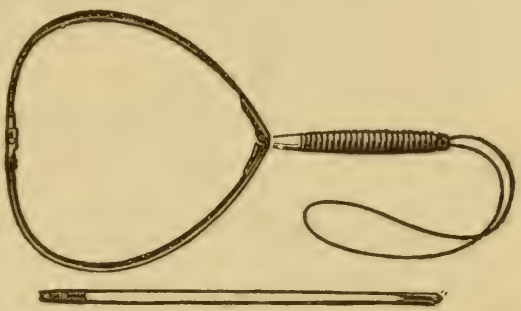
which it is carried over the shoulder. It will be seen that it is not necessary to remove the cord from the shoulder when landing a fish, owing to its stretehing enough to allow this to he done.

The wooden frame short-handled net made by The T. H.

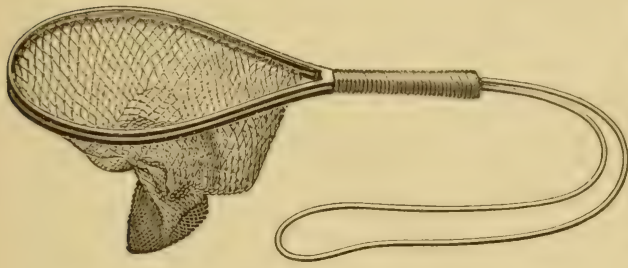

Chubb Rod Co., though not collapsing, is a very handy style of net for wading. It has a rubber cord to $\mathrm{g} 0$ over the shoulder. When not in use the net can be carried on the back, entirely out of the way.

A very useful article is a miniature dip-net for dipping minnows out of the bucket. It is furnished by Abbey \& Imbrie, complete, at a very moderate price.

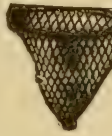

\section{Minnow-Nets and Traps.}

For catching minnows for bait-fishing, the most expeditious way is to use a linen or cotton minnow-seine, from 
three to five feet wide, and from five to fifteen feet long. These seines can be purchased mounted or unmounted. The mountings consist of 'cork and lead-lines, with their' floats and sinkers, and two handles or brails. The mesh should be quite fine.

A very simple and effective portable net is described as follows :

"Take a bung or round block of wood of two and one-half to three inches in diameter, and bore four holes opposite to each other in the edge of it. Then insert a piece of umbrella-rib, about twelve to fourteen inches long, in each hole. The holes must be made deep and small enough for the wire to fit tight. The paragon wire is the best. Leave the end of the rib that has the little eye in it outside. Lay the bung and wires on a square piece of mosquito-netting, and stretch it and sew it firmly at the four corners to the eyes in the ribs. In the center of the bung put a serew-ye, and in the center of the mosquitonet sew a piece of string. leaving ends about eight inches long. Any straight, stiff stick picked up on the shore serves as a handle, being made fast to the net by a strong piece of twinc throw-h the screw-eye, and with a pice of bread tied in the net with the string. and perhaps a small, flat stone to make it sink, it is ready to catch minnows. They will come over the net for the bread, and when it is raised quickly the resistance of the water causes it to belly, and the minnows will not get out. When bait enough has been taken, pull the wires out of the holes, drop the bung into the net, and roll it up on the wires."

Another simple affair is thus described:

"A globe of wire netting split in two, fastened at the bottom by hinges, and attached to a stick by strings from the top - this is the whole afiair, save a small place in the center for bait. The two hemispheres are so arranged as to open partially from their own weight, if allowed to touch bottom; or they can be separated by pulling one of the strings above mentioned. As minnows are generally found in shallow, clear water, it is easy to see when enough have entered the trap, to close and draw it out. This 
invention does away entirely with seining, and the disagreeable necessity of wading in the water. The pole or stick upon which the trap is hung may be made of any desired length. and jointed, thus permitting the entire apparatus to be packed in a small space."

Malcolm A. Shipley, Philadelphia, furnishes a folding net, much like one I have frequently used. It is a very convenient article, occupying but small space when folded. When ready for use it is about three feet

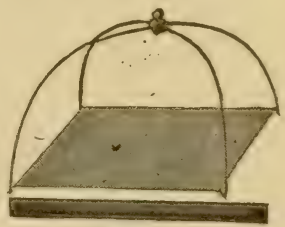
square.

The glass minnow trap patented and sold by Charles $\mathrm{F}$. Orvis, has been on the market for

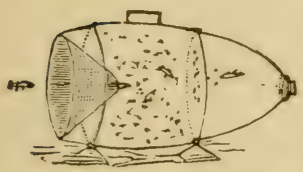
many years, and has proved a great success. It is constructed of heavy flint glass, about twelve by twentyfour inches. It is lowered into the water, and some bread crumbs placed inside. The cord by which it is lowered should be buoyed, if the angler is to remain away very long.

The galvanized wire trap furnished by Wm. Mills \& Son, is another ingenious device. It is to be lowered into the water and baited, the minnows having access at either end. The two halves nest

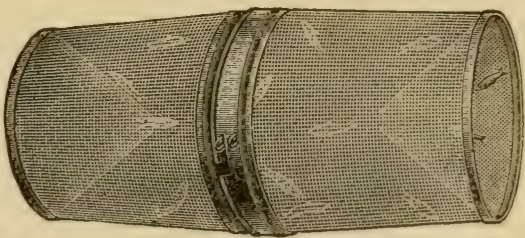
together, so that with a common water pail it can be utilized as a minnow-bucket. It is, when set up, about nine by twenty inches. 


\section{Minnow-Buckets.}

To the bait-fisher for black bass, the proper form of baitcan is quite an important item. There are two general styles, one for boat-fishing, and one for stream-fishing.

The best plan for a minnow-bucket for boat-fishing. and where a large pail can be utilized, is to have two pails, one fitting within the other. This form of pail is generally and conveniently made as follows:

The outer bucket is of heary tin, and made round, with a capacity of from two to five gallons; a stout wire bail or handle is attached, with a wooden or tin hand-piece. The inner bucket is also made of tin, to fit somewhat loosely in the outer one; but the top of this bucket should be an inch below the top of the outer pail. It has an opening, fitted with a lid on top, throngh which the hand can be readily inserted : and has a tin-hasp and loop for fastening securely. In addition. there is a flat tin-handle, in the form of an ards, on the top of the lid. by which the inner pail can be easily lifted out.

The inner pail is freely perforated on the top, bottom and sides. so that, upon raising it, the water leares it rapidly, and a minnow ean thus be readily selected. Whenever necessary, the inner pail can be taken out, the top sccurely fastened by the hasp and loop. and the pail sunk in the water to revive the minnows, while the angler is taking his lunch or siesta. Both pails should be well painted, inside and out. A better plan is to have the inner pail formed of copper or galvanized iron wire-cloth.

For fishing in a stream, where the angler is a-foot, a much smaller and lighter bucket must be used, on the score of portability and general convenience. In this case, the bucket is made single. usually. and of an oblong or oval shape, to admit of its being more readily carried. It is fitted with a handle or hail. and the top is soldered in, an 
inch or two below the rim of the bucket; and this top only is perforated. There is also a lid in the top, which is usually secured by a bolt of stout wire. A double pail, the imner one being made principally of copper or galranized iron wire-cloth, would be rastly more convenient, without adding much to the weight.

The most recent improvement in minnow-buekets that I hare scen is the telescopic minnow and live bait bucket patented and made by the Hall Manufacturing Company, Cleveland, Ohio. It is made round and oval, and of several sizes. The No. 1 oval bucket has a middle compartment for minnows, and two end compartments for frogs or other live baits, or ice. The round and smaller sizes are for minnows only. It is made

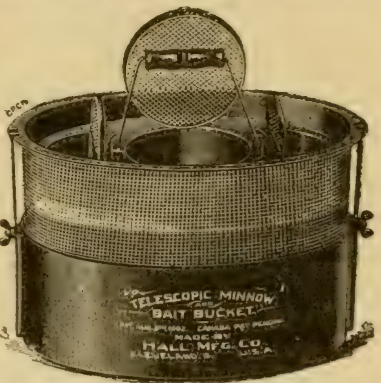

Open.

on a common-sense plan and is the best thing of its kind

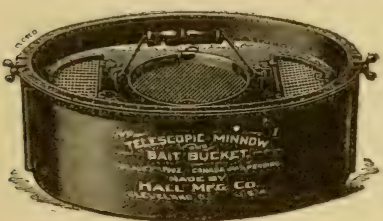

Closed. that I have seen. It is constructed in a substantial manner of oxydized copper on tin, or japanned green and lacquered.

A very convenient receptacle for carrying live frogs, crawfish, crickets or helgramites is the live-box sold by Wm. Mills \& Son. It has two compartments and is strongly made of galvanized wire cloth. The top has a sliding cover. Its size is about six by twelve inches.

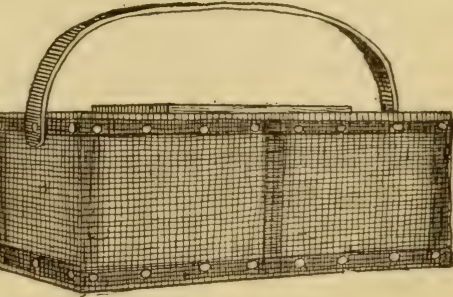




\section{FloAts, or Corks.}

The float should never be used when it can be dispensed with, as it is detrimental to good casting, and is always in the way. It lecomes necessary, however, in shallow streams, where the bottom is corered with snags, roots, weeds and other obstacles, and may be used in still-fishing, where crawfish. frogs or helgramites are used as bait; but, when used. it should be as small as possible, consistent with the weight of the sinker required, and should be employed for the sole purpose of keeping the hook away fiom the bottom, and not as an object of intense and constant observation to indicate a bite.

An egg-shaped, oral, long or barrel-shaped cork-float may be used ; or, still better, perhaps, a swan-quill or porcupine-quill float may be employed with adrantage, in situations referred to above.

There are several styles of adjustable floats that can be attarhed or detached without remoring the hook. One of the best is one with wire spirals at each end.

The Mascot float made by the Multi-Novelty Company, Burlington. Iowa, an be readily attached by doubling the line, inserting it through the hole in the float, and looping it orer the end. The same company make the Pacetty float, which is designed to overcome the difficulty of using a float in asting the minnow. The line runs freely through a tube in the float, and in casting it rests against the sinker or swirel, but when the bait reaches the water the weight of the minnow and swivel carries the line slowly through the float until it meets a check lastened at the required distance. For weedy waters it answers a good purpose.

The Bristol automatic float is made by the Horton 

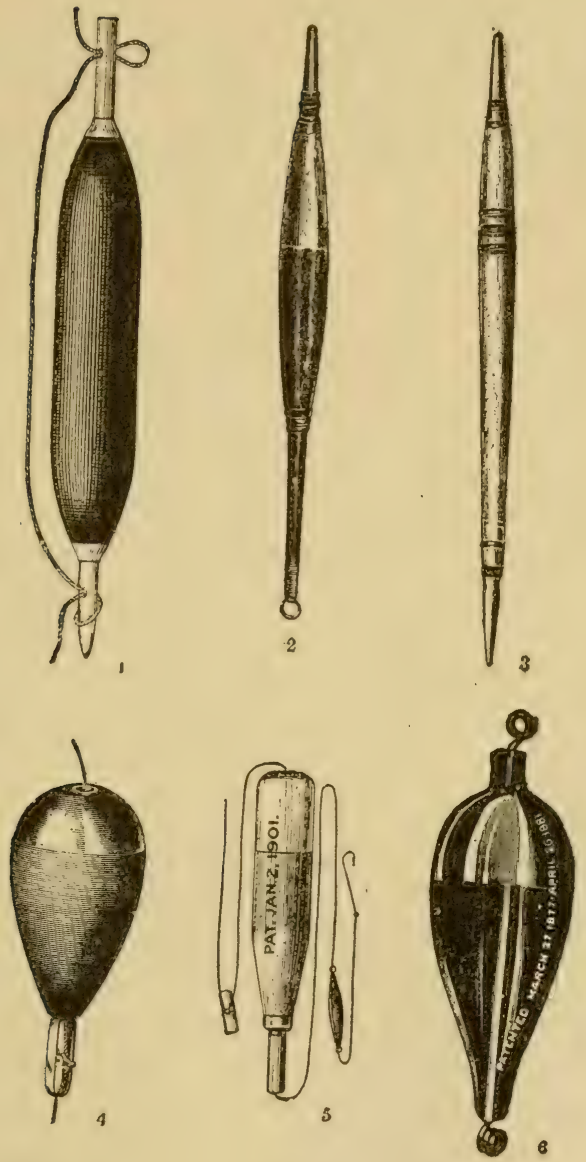

Floats.

1. MIascot float.

4. Bristol float.

2. Cork float.

5. Pacetty float.

3. Quill float.

6. Adjustable. 
Manufacturing Company, Bristol, Conn. It is intended also for use in casting the minnow. It is adjusted according to the depth of the water, and holds securely; but on reeling the line, and when the float reaches the tip of the rod, a cam is released allowing the rest of the line to be reeled up freely, and the fish landed the same as if no float were used.

\section{The Swivel.}

A brass or bronze box-swirel should always be employed in bait-fishing for black bass. It prevents, in a great measure, the twisting, linking and snarling of the line, so annoying to the angler. In rod-fishing, the smallest sizes - Yos. 5 or 6 - are large enough; and, usually, no additional weight or sinker will be required. The line should be made fast to one ring, and the snell of the hook attached to the other. In trolling, two swivels can be used with advantage - one attached to the snell of the hook or spinner, and the other attached to the line some two or three feet above. In trolling with the hand-line, larger swivels may be used - as Nos. 2 or 3 . Brass or bronze swivels should always be used, as they do not rust, a strong objection to steel swivels. When sinkers are used in addition, they should be attached about a foot above the swivel.

There are various other kinds of swivels of more or less utility, one of which has a swivel at one end and a spring catch at the other. Another is a swivel with spring catches at both ends. Then there is the triple swivel, and the spreader swivel, though the latter are used more for saltwater fishing. 


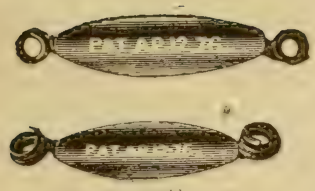

I
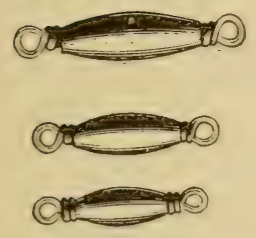

3

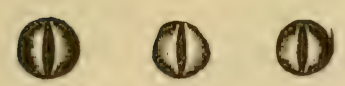

6
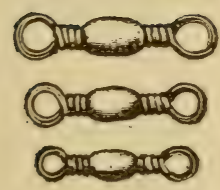

8

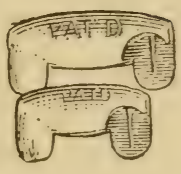

4

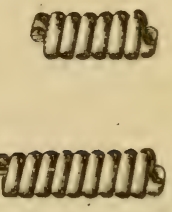

5

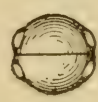

7

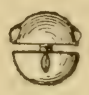

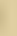

Sinkers ANd Swivels.

1. Adjustable.

4. Rangeley.

7. Mackinac.

2. Ringed.

5. Lead coil.

3. Swivel.

6. Split shot.

8. Bronze box-swivel. 9. Brass box-swivel. 


\section{SINKERS.}

Generally, in black bass angling, no sinker, in addition to the swivel, is necessary, the latter being heary enough to keep the live bait beneath the surface. But there are cases and times when the sinker is brought into requisition; for example, where the minnows used for bait are large and strong and keep on the surface, or when the stream is quite rapid or current swift.

When the ordinary ringed-sinker is used without a swivel, the line should be tied in one ring, and the snell of the hook looped in the other. The smallest-sized sinker is usually heary enough, though sometimes a larger size is necessary. Buckshot or small bullets should not be used when the oval sinker can be had, as they offer too much resistance to the water, and often cause the line to twist or kink.

The adjustable sinkers are the best sinkers to use, and should take the place of the old-fashioned ringed leads. The simplicity and effectiveness of the various devices by which they can be put on and taken off the line, without disturbing hook or bait, should receive the approval of all anglers, and render their adoption universal. They insure neatness and dispatch, qualities not to be despised in angling.

Most of the sinkers produced in this country are made by Edward Pitcher, Brooklyn, N. Y. They are ringed, the rings fast at each end, or with swivels, which turn freely. Then there is the adjustable sinker with spiral wire at each end. The Rangeley sinker is also adjustable. It is grooved through the middle, and has an ear at each end, which is to be bent over on the line, forming an oblong sinker. 
The leacl-coil sinker can be cut to suitable length, adjusted to the line and fastened by squeezing it tight.

The Mackinae sinker is a round sinker, divided into two halres, in one of which is a screw and in the other a corresponding hole, by means of which it is adjusted and made fast to the line.

The split-shot sinker is useful where a light one is required, and is easily adjusted.

Line Releaser.

A useful implement that will be appreciated by the fly-fisher on brushy streams is furnished by William Mills \& Son. Should the angler get " hung up" on the branch of a tree out of his reach, its release is an easy matter should he have this article in his pocket. He inserts the tip of his rod under the rubber band and raises the rod, with the "releaser," straddles the twig or branch with it, and withdraws the rod. A slight pull on the string attached to the instrumert cuts the twig, and the angler is again ready for the fray. It is furnished with a leather case for convenience of carrying.

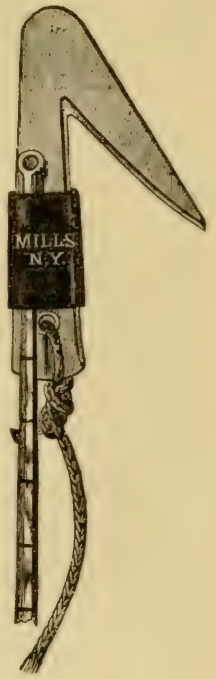




\section{Clearing-Ring.}

The hook, in angling, often becomes fast or foul in snags, roots, rocks, or grass, and frequently is thereby

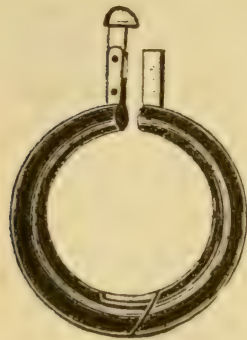
lost or broken, to the disgust of the angler. By the employment of a clearing-ring the hook can almost invariably be easily detached from these obstructions without damage. These are rings made expressly for the purpose, composed of brass or iron, with a hinge to admit of their being readily adjusted to the line. The method of using them is as follows:

The ring is opened at the hinge and the line encirelert. when the ring is again closed and allowerl to rum down the line to the point of obstruction; the weight of the ring detaches the hook, when it is drawn up, a hand-line being attached to the ring for this purpose. If the hook is very firmly fastened to the root or snag, the ring is raised a few feet by its cord and allowed to drop suddenly, when its weight will usually elear the hook. A rery good substitute for the clearing-ring, and one easily obtained, is the ordinary bar of lead, used for making bullèts. A hole is bored in the flat bar, through which the handcord is fastened. When used, the bar is bent around the fishing-line, forming

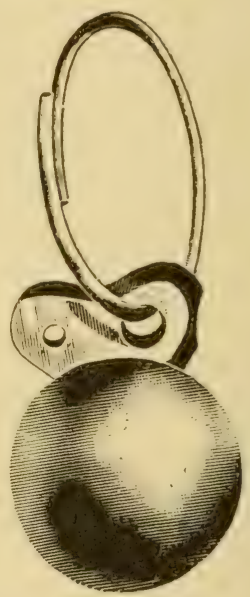
a ring, and is very easily attached or detached. 


\section{Disgorgers aNd Extractors.}

Very often a bass is hooked in the gullet, and sometimes in the stomach, though the angler should never allow him to gorge the bait to this extent. It is best to strike quickly, so as to hook him in the mouth. In the event of the bass swallowing the hook, it is necessary to cut out or tear out the hook, and often at the cost of scratching or lacerating the angler's fingers; and especially is this apt to be the case when a pickerel or pike-perch is thus hooked, their long and conical teeth being as sharp as needles.

To avoid this unpleasant feature, a disgorger is very handy and efficacious. It consists of a stout piece of wire, six or eight inches in length, with one end flattened; in this flat end a notch is filed, with cutting or sharp edges, when, by pushing this sharp notch along the hook, the latter is easily detached or cut out.

There are a number of ingeniously devised implements for the purpose. One of the best is Foard's patent fish-hook extractor or disgorger. The directions for its employment are to use the end of the instrument corresponding to the size of the hook, draw the line taut, and run the instrument down into the bend of the hook; then clasp the line against the side of the shaft, and push the whole down till the barb is disengaged, and the hook will come out with the instrument.

Another tool for this purpose has a $\mathrm{V}$-shaped knife at one extremity for dislodging the hook, the other being a screw-driver, while the shank of the

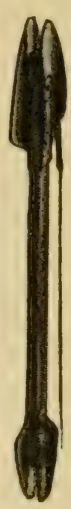
instrument is a file. It is a very useful, convenient, and portable combination. The file is useful for touching up the point of the hook, while the screw-driver may be required for taking apart a refractory reel. 


\section{Angler's Pliers.}

A very usaful little implement is shown here, combin-

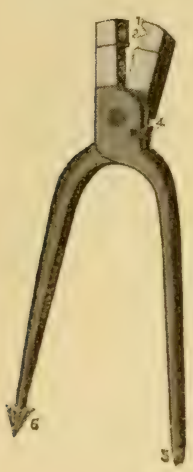
ing six different tools in one, namely: 1 , strong round-nosed pliers; 2 , knife for splitting shot; 3 , fine wire cutter ; 4 , strong wire cutter; 5, screw-driver; 6, reamer. It weighs only four ounces, and is made of the best steel and in the best manner, and will be found thoroughly reliable. The cut is one half the size of the pliers. With this tool, a bit of string and a piece of wire, a broken rod or a disabled reel may be quickly remedied or repaired. It should be carried in every angler's pocket.

\section{Hook Iock.}

Anglers are sometimes ammored by a damgling hook and line catching in brush or other obstructions when wading or fishing from the bank. The simplest plan to avoid this trouble is to place a rubber band around the rod above the reel, in which the hook or fly can be securely held, when moving about bushes looking for the next likely place to cast.

A little implement has been devised by A. WT. Bishop \& Son, Racine, Wis.. 
to orercome this difficulty. It can be instantly attached to the rod and covers the hook or fly, and locks it to the rod, when the latter is not in use. It is nicely finished and can be carried in the vest pocket.

\section{Line Dryer.}

One of the most desirable articles for the angler's outfit is the Nichols' line dryer. It can be folded into quite a small space when not in use. To dry the line clamp the dryer to the rod, about eighteen inches above the reel, after having extended the arms, and fastened them by the thumb nuts to right angles. Attach the line, throw off the click or drag, and wind on to the frame quite loosely. The frame with the line can then be removed to a suitable place until dry. It is furnished by Abbey \& Imbrie at a small cost.

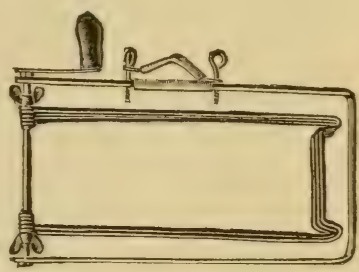

Closed.

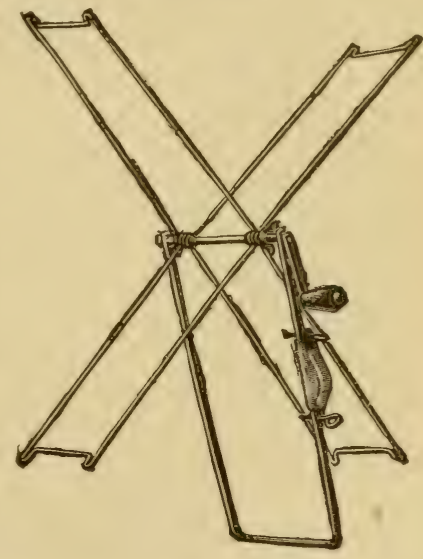

Open.

\section{Combination Knife and Screw-Driter.}

Two pocket tools that I would not be without are the combination screw-driver and knife, and the pocket caliper sauge, made by the Billings \& Spencer Coompany, Hartford, Conn. The former has three sizes of screw-drivers, 
of just the sizes for reel screws, and in addition a good strong knife blade, all fitted into a nickel-plated handle. By raising the locking bolt and pressing forward the slide to

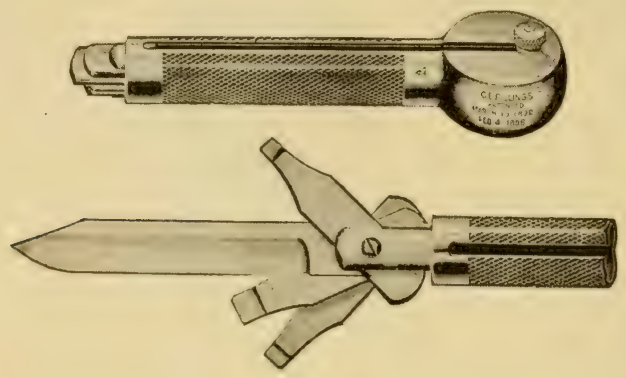

end of slot the blarles swing out: solect the one required and draw the slide hack into the handle and the tool is ready for use.

\section{Pocket Caliper Gauge.}

This is a light and convenient tool. graduated on one side to 6 th ths and on the other to 100 ths of an inch, just the instrument for taking the calibers of rods, hooks, lines, ete. The thumb-screw is counter-bored to receive a spiral spring which bears on the nut and washer, thus creating a moder-

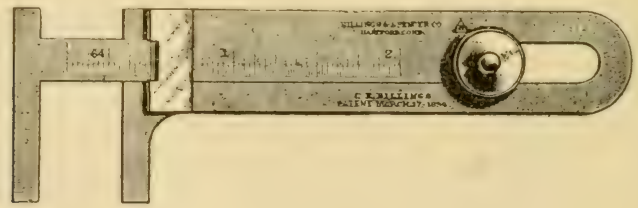

ate friction, which, when the nut is loosened, facilitates the setting of the gauge to the desired measurement. It is finished in the best manner, and opens two inches. 


\section{Wading Pants and Boots.}

Cervantes has said that one can not cateh trout and yet keep one's breeches dry, which remark will apply as well to the black bass fisher. In warm weather, and where the water is not too cold, I prefer to put on a pair of brogans and a suit of old clothes when wading a stream. But often. the water is too cold, or the angler is afraid of rheumatism, when rubber hip boots or wading pants are required. Either becomes quite damp from perspiration, and should be thoroughly dried immediately after use, otherwise they soon become useless. Wading pants especially require much care. They should not be exposed during winter to extreme cold, nor placed near a stove or radiator when not in use.

Unless the angler procures the very best wading pants," I would advise him to stick to hip boots, for cheap wading pants are a fraud. The best are imported, as

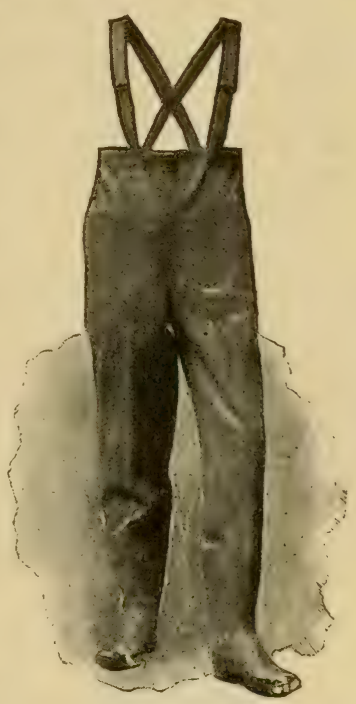
more attention is given to the manufacture of them in England than in this country. Abbey \& Imbrie furnish a ligh quality of mackintosh pants with rubber feet that are as good as can be bought anywhere. But for that matter any of the tackle dealers of known reliability will furnish them.

\section{WADING: SHOES.}

The best wading shoes have rubber soles and canvas uppers. They dry quickly and do not harden with drying. 
Next best are leather brogans. They are very comfortable and answer the purpose admirably, though it is necessary to take the best care of them in order that they may be kept soft and pliable; a liberal application of castor oil, while wet, is the best plan for accomplishing this result. Very few angler's, however, attend to this matter as they should, and are very loth to give the needed attention to leather wading-shoes when through fishing; consequently, when next needed they are as hard and stiff as a board. liading-shoes of any kind should have soft iron hob-nails in the heels and soles to prevent slipping on rocks.

\section{Rod and Reel Cases.}

Leather cases for the rol and reel are very convenient and desirable articles, especially for the angling tourist.

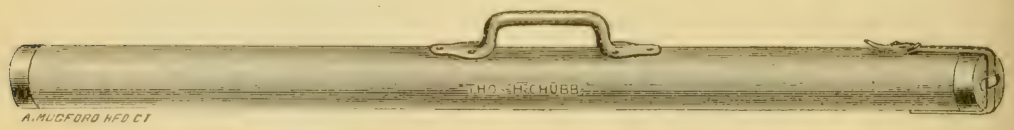

A good and highly-prized rod or reel should have the best (are; and a rorl. cipectally, is liable to serious injury when protected only by a common canvas cover.

The Thos. H. Chulb) Fod Co. of Post Mills, Vt., the well-known manufactures's of anglers' goods, make a specialty of leathere rod and reel cases. They are made of heavy bridle leather, with handle, and if re-

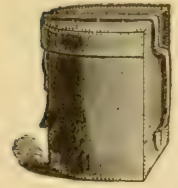
quired, a padlock. The rod cases are made to hold one or more rods. To the angler who ielights in completeness of outfit, I can cheerfully recommend these useful articles. They will be duly appreciated by any angler who has ever made an extended trip to the woods, lakes, or streams by the usual modes of conveyance. 


\section{Camping Bags.}

I have had more solid comfort, when camping, from the use of one of Kinstler's "war bags" than from any other device of the kind.

It is a non-rigid grip packing - bag, convertible and adjustable, and always of the right size. It is made of heavy tancolored waterproof canvas, height 16 inches, length 23

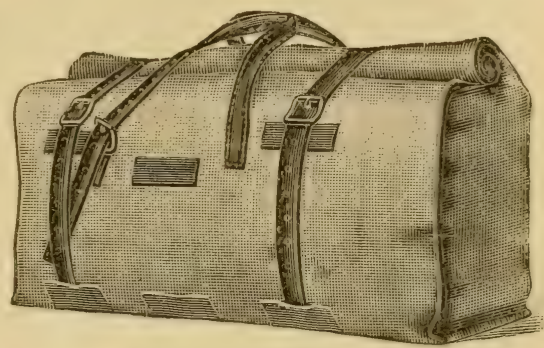
inches, width 10 inches. It has plenty of straps for handles or for carrying as a knapsack. It is a very compact article, either full or half full. It is made by Mr. J. Kinstler, Chicago, Ill.

\section{Fishing-Boats.}

In black bass fishing on lakes, ponds, and broad deep rivers, a boat is a sine qua $n o n$, and a part of the angler's outfit that should receive that attention which its importance demands. A good boat in every particular is a blessing and a comfort that can hardly be orcrestimated.

As a rule, anglers, while employing none but the best tools and tackle, do not give the same thought and care to the boats they use. They are inclined to arcept any thing in the shape of a boat that will float, and seem to have an iclea that all boats are cranky and leaky, from the calm indifference with which they will sit for a day with wet feet, or the philosophic unconcern with which they will spend half their time in bailing out the water.

In the first place, a boat for fishing should be safe and 
light, dry, and capable of being easily rowed or paddled; and, in order to meet these requirements, considerable attention should be given to its model and construction. It should not be too long, and should have beam enough to give stability, but not so much as to render it logy. A well for minnows may be constructed under one of the thwarts, with a two-inch hole in the bottom covered with brass wire screen cloth, through which the water may have free access. With such a contrivance minnows will live for weeks.

Of late years great attention has been giren by builders to the construction of suitable small boats, for the angler and sportsman, at a moderate price, so that there is now no excuse for the employment of such death-traps as leaky scows and cranky, unsafe skiffs.

I am aware that most anglers, who use boats, depend on hiring them at the usual fishing resorts; but that is no excuse, for the amount usually paid for boat hire during a fishing vacation would be more than ample for the purchase and freight charges of a good, safe, dry, and comfortable boat. 
PART III.

ANGLING AND FLY-FISHING. 




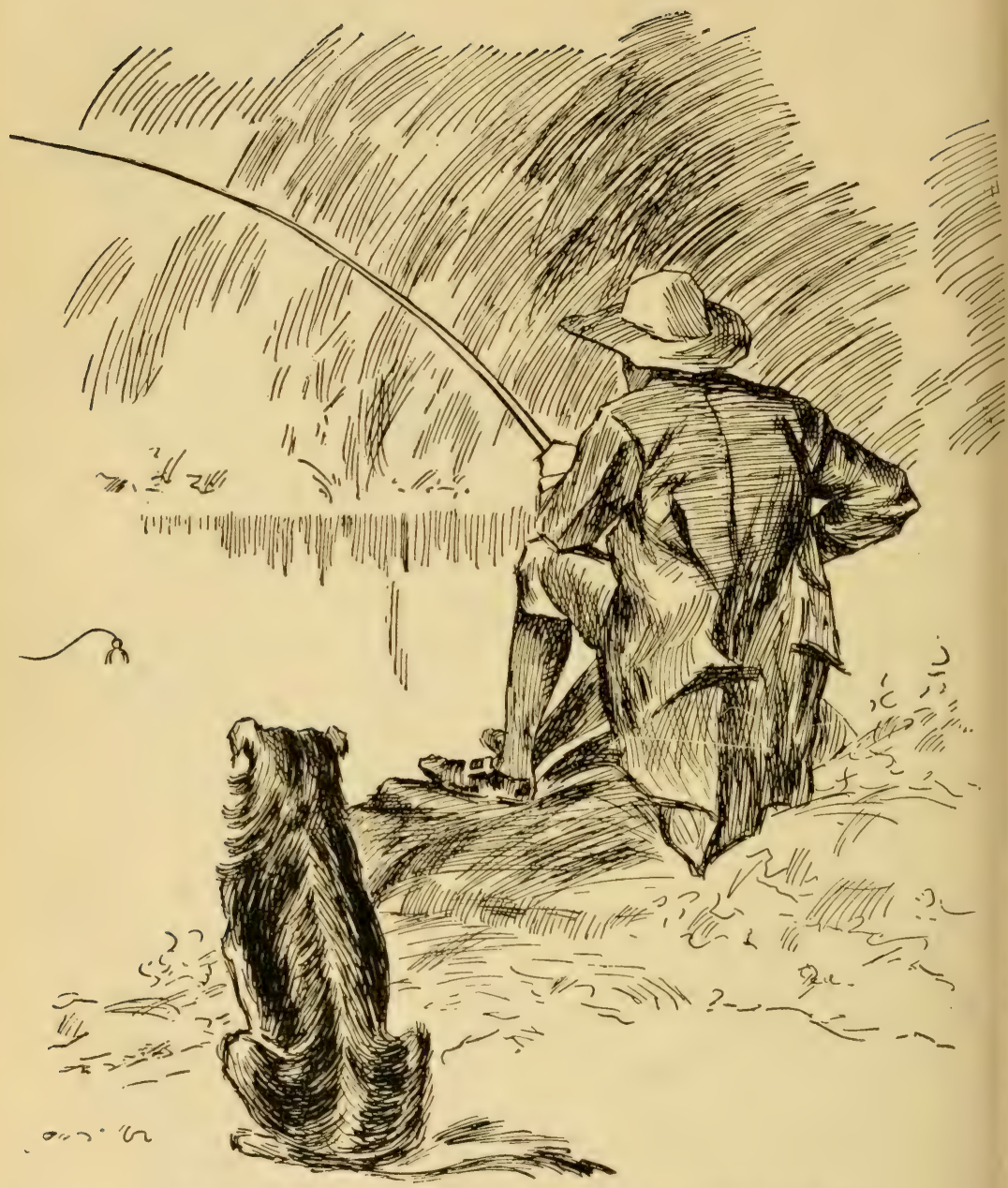

KENTUCKY BASS FISHER OF YE OLDEN TIME. 


\section{CHAPTER XVIII.}

\section{THE PHILOSOPHY OF ANGLING.}

"You are assured, though there be ignorant men of another belief, that angling is an art, and you know that art better than others; and that this truth is demonstrated by the fruits of that pleasant labor which you enjoy,- when you purpose to give rest to your mind, and divest yourself of your more serious business, and (which is often) dedicate a day or two to this recreation."IZAAK WALTON.

Is the days of good old Father Izaak Walton angling was, as stated by him in the title of his famous book, the "contemplative man's recreation." While this is no less true in our own day, the art of angling has extended its where of usefulness by becoming not only the recreation of the contemplative man, but of the active, stirring, overworked business and professional man, as well. While in the comparatively slow-coach days of the quaint Walton it was rather a recreation of choice, it has in this age of steam become, in a measure, one of necessity.

The Americin idea of rest and recreation seems to hare been based upon the Mosaic law of resting on the serenth, or last, day of the week. A man must first gain a competency and rest afterward, even if it took seren times seren years to gain the first condition, wealth, for then. only would he be entitled, or in a proper condition to enjcy, his otium cum dignitate.

In the rapid race for wealth and distinction men labor night and day, with mind and muscle, especially during the seasons of business actirity. But ton often. alas, they labor in vain and find that the "bubble reputation," or 
the "wealth that sinews bought," has in a moment been swept away after years of toil and anxiety. Or, if they make their footing sure, they find, too often, that the result has only been attained at the expense of a permanent impairment of health, for which the dearly bought treasure is but a sorry recompense; and the oft-imagined and fondly looked for goal of a life of peace and quiet and the enjoyment of the hard-earned competency, has been realized to be one of short continuance or of long bodily suffering.

To keep pace with the rapid strides of trade and traffic, as much labor is now performed in one day as was formerly done in a week. Consequently, between the busy seasons, or "heats," in this race for wealth and place, men find it absolutely necessary, not so much from choice as necessity, to rest and recuperate and build up the exhausted energies, the tired brain and relaxed muscles, and to gird up the loins for renewed efforts.

The necessity being acknowledged, the question then arises: in what way can this rest and recreation of the muscular and nerrous tissues of the body be best attained? When men think of rest and relaxation their thoughts turn naturally to the woods, to the fields, to running streams and quiet lakes, or the sea-shore. If it is simply a Sunday stroll, their steps naturally and irresistibly lead them to green fields, or the river side; or a drive along the country road with its hedges, and birds, and crossing brooks. If - it is a day's holiday, it must be a picnic in the grand old woods, and near a lake, or stream, or at least a babbling rill. The very idea of perfect rest is associated with mossy banks and cool sparkling waters. It is doubtful if there is a sweeter line in human language, or one more expressive of perfect bliss, of lasting peace, of complete rest, of true happiness, of quiet contentment, than that of the Psalmist: 
"He maketh me to lie down in green pastures: he leadeth me beside the still waters."

But the question: where can rest be found? has already been answered in the crowds of tired pilgrims - they are called pleasure-seekers, but they are looking for rest - who are seen each summer-time wending their ways by rail and steamer to the mountains, to the sea-shore, to the Adirondacks, to the Great Lake region, to the wilds of Maine and Canada, to the charming streams and lakelets of Wisconsin, Michigan, and Minnesota, or simply to "the country" any place in fact is their Hecca where may be found rest and quiet, green fields, green hills, green trees, and clear, cool water.

Then, the season for angling coming as it does during the midsummer vacation, in the pleasantest weather and during the lull in active business matters, presents at once the means and the opportunity for enjoyment and rest, for recreation and peace. Horace Greeley once said to the writer that he had been for years eagerly looking forward to the time when he could lay down his pen, for a few days, and "go-a-fishing;" but that time never came during his busy life. His dreams of a brief season of what he considered the very essence of rest and contentment were never realized - he died a martyr to an overworked brain.

Rest and recreation to the active mind does not mean mere idleness, or as it is more poetically expressed: dolce far niente; this, to many, would be more irksome than the hardest work. Many men have a horror of going into the woods, to the wilderness, to the lakes, or the sea-shore, because there is nothing to do, nothing to occupy their minds, nothing to save them from ennui after the novelty wears off. The busy, active man can secure rest only by diverting the muscular and nervous energies in new and 
unaccustomed channels. This may be accomplished, in a measure, by cards, chess, music, reading, etc., as purely intellectual recreations; while riding, driving, boating, yachting, shooting, etc., furnish ample means for muscular skill and exercise; but angling brings into play both the mental and physical capacities. To be a good angler requires good judgment, much patience, ralre skill, a full share of endurance, and a lively imagination; the latter quality is not absolutely escutial. but it helps mightily when "luck" is bad, and on it depends the asthetic and poetic features of the art.

But those who are disposed to "take time" to inclulge in these or similar recreations, in our country, are comparatively limited. In Eneland it is ennsidered part of a gentleman s education to know how to ride, to row, to shoot, to sail, and to cast a fly, and he is the better for it, morally, physically, and jutellectually: In our own country it is too often considered " a waste of time" to acefuire or practice these manly and healthful aceomplishments. Our girls may learn music, and dancing, and painting, as means and acquirements necessary to the securing of a hushanil, but any attempt on the part of our looss to learn any of the manly sports, in a regular and systematic way, must be frowned down as opposed to all our irleas of thrift and economy, and a gross misuse of "time." What we neerl is more muscular (hristianity; we would then have sounder minds in sounder bodies.

I few weeks taken from the fifty-two composing the year and devoted to angling. shooting, boating, or "camping out," would not be missed in the long run from the business man's calentar. but, on the contrary, would return an interest, which. though it could not be computed by any rate of per centage, would be sensibly felt and realized in 
a clearer brain, a stronger body, and a better aptitude for business. The clergyman would acquire broader views of humanity, and preach better sermons. The physician would better appreciate, and oftener prescribe, nature's great remedies, air, sunshine, exercise, and temperance. The lawyer's conscience would be enlarged, and his fees possibly contracted. The poet's imagination would be more vivid; the artist's skill more pronounced. Nerve would keep pace with muscle, and brawn with brain.

I have purposely aroided any allusion to the Gipsy blood inherent in our reins, or the savage traits yet manifest in our flesh, and their liability to crop out, as evidenced in our love for nature and nature's arts. I do not look at it in that light. I claim that the more enlightened and civilized a nation becomes, the more it is interested in the works of nature and her laws; that the more progress we make in the arts and sciences, and all the achievements of a high state of civilization, and the more artificial and advanced we become in our ideas of living the more readily we turn for rest and enjoyment, for recreation and real pleasure, to the simplicity of nature's resources,

"Knowing that Nature never did betray The heart that loved her."

Angling is an art, and it is not beneath the dignity of any one to engage in it, as a recreation. It is hallowed by "meek Walton's heavenly memory," and has been practiced and commended by some of the best and truest and wisest men that ever lived; for, as Father Izaak says: "It is an art, and an art worthy the knowledge and practice of a wise man." Did the art of angling require an apologist, I could here produce evidence, in precept and example, of 
good and wise men of all ages, from the days of the Fishers of Galilee down to the present time, upholding and commending the moral tendencies and the healthful influences of the art of angling, and its virtue of making men better physically, intellectually, and spiritually.

"O, sir, doubt not but that angling is an art," says Piscator to Tenator; " is it not an art to deceive a trout with an artificial fly? A tront that is more sharp-sighted than any hawk you have named, and more watchful and timorous than your high-mettled merlin is bold?"

Is it not an art to glide stealthily and softly along the bank of a stream to just where the wary hass or timid trout is watching and waiting, ever on the alert for the slightest movement, and lieenly alive to each passing shadow; to approach him unawares; to cast the feathery imitation of an insect lightly and naturally upon the surface of the water, without a suspicious flash, and without disclosing to his olservant eyes the shatow of the rod or line; to strike the hook into his jaws the instant he unsuspectingly takes the clever ruse into his mouth; to play him. and sul)due him, and land him suceesfully and artistically with a willowy rod and silken line that would not sustain half his weight out of the water? Is not this an art? Let the doubter try it.

"Doulst not, therefore, sir, hut that angling is an art," says Walton, "and an art worth your learning. The question is, rather, whether you he calpalle of learning it?"

Exactly so, Father Izaak; the question is, not merely "to be or not to be," but whether one is "capable" of learning it; for though any one may become a bait-fisher, it is not every one that can learn the fly-ficher's art; for, continues Walton. "he that hopes to be a good angler, must not only bring an inquiring, searching; olserving wit, but 
he must bring a large measure of hope and patience, and a love and propensity to the art itself; but haring once got: and practiced it, then doubt not but angling will prove to be so pleasant, that it will prove to be, like virtue, a rewari to itself."

The art of angling, with the improrements and appliances thereunto pertaining, will not suffer by a comparison with the progress of any other out-door recreation. The love of angling increases with the lapse of years, for its love grows by what it feeds on.

Wiser and more healthful and more humane sentiments now prevail among the guild than formerly, so that its practice more nearly approaches and deserves its appellation of the "gentle art."

Fishing for count, and the slaughter of the innocents, and the torturing of the fish, when caught, by a lingering death, now meet with the opprobrium of all true disciples of the craft, and have become abhorrent and despical)le practices.

The genuine angler "loves" anyling for its own sake; the pot-fisher "likes" fishing for the spoils it brings, whether captured with the hook, spear or seine.

The angler wending his way by the silvery stream, or resting upon its grassy banks, has an innate love for all his surroundings - the trees, the birds, the flowers - which hecome part and parcel of his pursuit; beeme true and tried friends and allies without whom he could no more love his art, nor practice it, than the astronomer could riew the hearens with pleasure on a cloudy, starless night.

It is the lore of the stream in its turnings and windings, its depths and its shallows, its orerhanging branches and grassy slopes, that gives to the art of angling its chiefest charm, and presents the bass or the trout to the angler in 
its true and proper setting of leaves and flowers and sparkling water. If it were otherwise he would find as much pleasure in fishing in the flume of the fish-culturist, or in viewing the fish in the fish-monger's stall.

Truly, the stream and its surroundings are all in all to the angler. I am not much given to preaching, though I come of a race of preachers, but I can not refrain from presenting to the reader the following eloquent similitude and beautiful comparison between the angler's stream and the stream of life, showing the easy and natural transition from the love of angling to the love of nature and nature's God. I feel more like presenting it because it is an extract from a sermon of one (Rer. Dr. H.) who has both the love of God and the love of angling deeply engrafted in his heart:

"Act, therefore, while the day calls. Live its life as if life were complete in it. Not that it contains all varieties of experience, but so joins the days before and after as to make them one stream, which your spirit should wade eheerily as the trout fisher wades his brook.

"His brook is wild, because the trout loves waters where boats (an not follow them, nor even lumber logs roll free; waters that twi.t and plunge, and shoot and eddy, with many a snag in the midst and fallen tree across.

"And there the fisher seeks them by an instinet like their own -loring the bends that lock the pools, the shoals that embank the deep, the concealment of trackless woods, with their twilight noons and mystic noises, and every difficulty that teases him to more eager quest of his water-sprites.

"When no upward flash meets his fly he reels his line in expectation to give a merrier hum to the next throw, and again to the next, until all expectations are fulfilled at once when his wrist tingles to the trout's jerk and swirl and jump.

"And still that wrist tingles through casts that take no prize, until another capture renews its thrill. Broken leaders, snarled lines, torn garments, bruised limbs, do not spoil his hilarity, 
whirh feels the whole day's sport in erery minute, the whole brook's beauty at every step.

"And so with life. It is to be lived as a whole. Happiness comes from an energetic sense of its entire significance in every passing phase of it - in mystery, as giving value to knowledge in failure, as the gauge of success - in evil, as the condition of good, which indeed is but evil overcome, and without the evil could not be - and in all alike as strides and casts of the confident soul, whose trout-stream from end to end is God.

". And if by the e the soul gains nought else, it gains immortal health; fills its creel with secrets of infinite love and wisdomwisdom too loving to wish less than man's perfection-love too wise to spare any pain necessary to attain Godlike end. Luck enough for time or eternity. Nay, eternal sport in time." 


\section{CHAPTER XIX.}

\section{CONDITIONS WHICH GOVERN THE BITING OF FISH.}

"So I have observed, that if it be a cloudy day, and not extreme cold, let the wind sit in what quarter it will, and do its worst, I heed it not."- IzAAK WALTON.

To seck to know all the conditions, positive and hypothetical. qualifying and exceptional, which govern the "biting" of fish, is about as rain and discouraging a pursuit as the search for the philosopher's stone.

To know, positirely, before leaving one's office, countinghouse, or workshop for a day's outing, that it is the day of all others of the season, and that the phase of the moon, the conditions of sky and atmosphere, the direction and force of the wind, and the temperature and condition of the water are just right to insure suceess, and to linow just what bait or fly to use, and in what portion of the strean to fish, mnler these conditions, implies a state of knowledge that can never be attained by ordinary mortals; and though we are created, "little lower than the angels," it involves a pursuit of knowledge under such extreme difficulties that even prescience and omniscience are but ciphers in the total sum, for it leaves out the most important factor in the calculation - the fish itself.

Yet, it is in just this hope of reducing the matter to the certainty of a mathematical proposition that some anglers are continually puzzling their own brains, and taxing the patience of their angling friends.

They imagine that fish, somehow, form an exception to the rest of the animal creation, and are governed in their 
feeding, or "biting," by certain laws, as unchanging as those of the Medes and Persians; and that these immutable laws have an outward expression in certain states and conditions of weather and water; and that it is only necessary to ascertain the peculiar combination of wind, weather and water, under which fish feed, nolens volens, to be able to effect their capture easily.

The glorious uncertainty attending the "biting" of fish, eren at apparently farorable times, has been observed for ages, and has invested the gentle art with a glamour, and an air of mystery, in which the element of chance, or luck, is a prominent feature. The angler wending his way homeward is accosted at every turn with the interrogatory of, "What luck?" while "fisherman's luck" has become an universal synonym of failure.

Irany anglers, in lieu of more cogent reasons, have conreniently relegated this whole question to "luck," and have ceased to trouble themselves much about it, taking the good with the bad, in a spirit of calm philosophy or in meek submission to the inevitable.

Even while engaged in solitary angling, so conducire to quiet meditation, the habits and idiosmerasies of fish do not often oceupy our thoughts, but other and wholly irrelerant themes. And eren with all the information that can be obtained, by close and careful observation of the habit's of fishes, and the nature of their surroundings, there is still left much to be explained, and some things that seem to be beyond our comprehension, which we might safely leave to chance or luck, until we understand them better.

And perhaps it is best so, for there has ever been a delightful uncertainty attending the angler's art, and therein lies one of its chiefest charms; for while it stimulates the angler to renewed effort, it consoles him in defeat. The 
pleasures of anticipation have ever exceeded those of fruition, and ever will while "hope springs eternal in the human breast."

The angler spends the evening before his "day's fishing" in overhauling his tackle: polishing the ferrules of his trusty rod; oiling his reel; looking for weak places in his line; arranging, loringly, his leader, hooks and flies; and finds enthusiastic enjoyment in the examination of his treasures. and in pleasant retrospective and prospective reveries in connection therewith.

He retires with contented mind, and an innate consciousness of unbounded success on the morrow, and dreams of arching rod and leaping fish. of mossy banks and nurmuring streams, of cool shadows and spicy hreezes; and when morn hath "with rosy hand unlarr"d the gates of light." he sallies forth with buoyant footsteps, his breast swelling with fond anticipation. and in that happy and expectant state of mind known only to lovers of the angle.

Perhaps he returns at close of day, weary and footsore, and with an almost enpty creel; what matter? All through the lovely day his spirits have never flagged; his last cast was made with even more hope and confidence than the first. And though his creel be empty, his heart is filled with the music of the birds, the purling of the stream, the fragrance of the flowers, and, above all, with love for his Creator; and it has set him thinking of that eternal stream of time clothed with everlasting groves of never-changing green.

And. then, the day has simply been an "mulucky" one for fishing; yesterday was no doubt a " wood day" and to-morrow will he hetter. He finds emsolation in ac. counting for his "ill-luck," and can easily see a reason for 
it in some peculiar phase of the water, the wind, or the weather.

Now, while it is not wholly a matter of luck, on one hand, and while, on the other, it is useless to expect to obtain an invariable law in respect to the "biting " of fish, there are many things that we can learn by intelligent observation.

It involves no great comprehension of the sciences of ichthyology, meteorology, hydrography, entomology and botany, as professed by some, nor of the mysteries and hocus-pocus of the art as practiced by other's; for there is often as little reason in the repeated change of a cast of flies by the scientific fly-fisher, as in spitting on the bait by his humbler brother; yet both have unbounded faith in their respective methods, and probably faith has as much to do with successful angling as any one attribute.

But why do fish eagerly take the bait one day, and utterly refuse it the next, when, apparently, all other conditions are equal? This is a poser, and has baffled observant anglers for ages, and will, in all probability, never be solved satisfactorily. As a short cut to its solution, it might he said that they were hungry one day, but not so the next. Certainly a very reasonable conclusion if it were sustained by fact, which it is not, if we judge hunger by its usual manifestations: for fish seem to bite best on a full stomach, and often refuse the proffered bait on an empty one; this fact is patent to all observant anglers, and I have proved it in many instances.

But let us begin at the beginning.

The great problem of life with fishes seems to be to eat and aroid being eaten. Tery well. Now, which is the controlling influence in a fish's mind - if he has any. perhaps, in deference to authority, we had better call it in- 
stinct - his desire to eat, or his desire of self-preservation? Now, right here, may be involved the fundamental principle governing this whole question of a fish's "biting."

Let us see. That fish can abstain from solid food for" an indefinite period, procuring some nourishment from the small organisms in the water they breathe, as in confinement, during hihernation, and during the breeding season, is well known, and needs no corroborative evidence here.

That, when they do feed, and the supply of food is abundant, they completely gorge themselves - some eren ejecting the contents of their stomachs to enjoy the gratification of refilling them - is also an authenticated fact.

When their stomachs are thus filled and gorged with food, it is reasonal,le to suppose that, like other predacious animals, they remain listlessly about their haunts, or retire to some sechuded retreat, to digest it at their leisure; and, during the process of digestion, refuse to notice their usual food; for I have frequently observed black bass remain motionless for hours, except a slight morement of the fins, utterly regardless of the schools of minnows that were swarming alout them, and this at a season when they usually "bite" the best.

Now, this alternate feasting and fasting may be a necessary habit, to enahle fish to meet the exigencies of spawning, hibernation (in some), and the vicissitudes of the ele. ment in which they live, and the abundance or lack of food at certain times.

Streams are often rendered turbid by heary rains, and lakes and ponds by what is termed "working" or "blossoming." At such times fish can not see well enough to find their fond or discern their enemies, and consequently lie secure in their hiding-places. When the water becomes clear, they again venture forth to eat and be eaten. 
Then, heary and continued rains, violent winds, and the change of season, affect the food-supply of fishes, and, consequently, the fishes themselves. These various causes make fish seem capricious in their time and manner of feeding.

Then, again, while all the conditions may be farorable for their feeding, they may be deterred from seeking their food by a fear of enemies, and only renture forth when the cause of such fear has disappeared, or their qualms of stomach overcome their prudence.

But little can be learned in this respect from fishes that are confined in aquaria, or from those that are artificially cultivated, for these unnatural conditions presuppose a change in their habits.

We know that fish, in their native waters, are quite timid, and ever on the alert for danger - a footstep on the bank, or a shadow cast suddenly on the water, will cause them to hastily skurry away.

No food, however tempting, can entice them so long as there is an appearance of danger, and their caution is then set down as eccentricity.

Now, all this may, or may not, be; but it is as reasonable as any other theory; and this habit of alternate feasting and fasting. for a longer or a shorter time, will explain, in some measure, many of the features in regard to the uncertainty of "biting" in fishes of inland waters.

We really know rery little about it. We only know that when fishing a farorable locality where there are "thousands " of black bass, or even in small, circumscribed water's where there are certainly "hundreds." we do well, by the most careful fishing, to secure a half-dozen or a score of fish, as the case may be, on the most propitious occasions.

Why is it then that so few, out of so many, respond to 
the angler's fly or bait? It is best that it is so; but why is it so? This is a query that naturally rises to the angler's mind, especially after an unsuccessful day.

I might answer this question by asking another: Why is it that the sportsman in a day's outing. with the best dogs, finds so few grouse or quail in comparison to the great numbers known to "use" in certain localities?

The inference is plain in either case, for self-preservation is the first law of nature; but while the sportsman is fully conscious of this, the angler is usually not so logical, becanse he does not reflect upon the fact that the fish is as fully aware of his presence as the grouse or quail is of that of the sportsman and his dogs.

Then again we should not expect to find all the fish on the feed at the same time; if we did so we would have no cause to complain of their not rising or biting. In the struggle for existence among animals, including fishes, it is the majority that obtains enough to satisfy its wants, and the minority only that does not. Then it is from the minority, in all probability, that we must look for the few that are likely to see and take our lure.

Predacious fishes feed almost entirely at night, only the hungry ones, perhaps, that do so during the day; and though we often take fish with their stomachs full, they are evidently still on the feet. for such food is usually in a fresh or undigested condition. showing that it has been recently swallowed.

Predacious fishes are more active during the night, and. I believe, rest or sleep during the day, while the smaller fishes, as minnows, ete. are more active during daylight; for it is not unlikely that they seclude themselves, or keep in very shallow water, during the night, to prevent their being swallowed hy their larger and piscirorous congeners. 
As predacious fishes then feed mostly by night, we would naturally expect to find them at that time where their food was most plentiful; and this is really the case, for I have observed that they were always near the shores or on the shallows at night, in water so shallow, in fact, that their dorsal fins were often out of the water. Any one who will take the trouble to proceed cautiously along the shores at night, with a lantern, can verify this statement.

It is well known that the last few hours of daylight are the best for fly-fishing, which I account for by the fact that the fish are then approaching the shallows and shores in their nightly search for food; and as they only rise to the fly in comparatively shallow water, the conditions are thus more favorable for the fly-fisher.

The hypothesis, then, that game-fishes feed mostly at night and rest or sleep by day, and that it is only the few that failed to fully satisfy their appetites the night before that are apt to respond to the wiles of the angler, is quite a reasonable one, and one that will account for much of the "bad luck" of the angler.

As before stated, there is much that can be learned by closely observing the habits of fish, the character of their haunts, and the nature and variety of their food; so as to enable the angler to know, so far as can be known, when and where to find the fish at certain seasons, or at different stages of the water; when they are most inclined to "bite;" and to know, approximately, what bait to use.

This information can be acquired in no other way but by patient and continued observation; and, without it, all is guess-work. It is just as essential to the angler to know where to fish, as to know how. If he has a fair knowledge of the habits of game-fish, he can at once seek out the most likely places, on lake or stream, by seeming intuition. 
Black bass are found at different localities in the same waters, at different seasons, and frequently shift their quarters many times during the same season, depending on the nature and locality of their food, the influences of wind and weather, condition of the water, etc.

Thus, early in the season, they will be found on streams in shallow water, just below the rapids, or " riffles," where the water is warmest, feeding on helgramites and other larræ, crustacea, minnows, etc. As the water gets warmer, they resort to stiller water, under overhanging trees, and feed upon the surface when the insects and flies appear. Still later, they seek greater depths, adjacent to shelving banks, gravelly shoals and rocky ledges, seeking minnow, crustacea, ete.

They may be found one day in water. say ten feet deep. and the very next day be seen in the shallowest water near shore. I will mention a striking instance of this kind:

On one occasion. I went in company with a party of expert anglers to Upper Nemahbin Lake, near Delafield, Wisconsin. My companion was Captain B., who exhibited considerable impatience and concern becanse of the other boats starting ahead of us orer the farorite fishing-ground; but I saw that the three other boats were proceeding over this ground - where. on the preceding day, I had taken a fine lot of bass - without getting so much as "a bite."

We followed in their wake, casting right and left along the edge of the bulrushes, but in vain; until, finally, we reached the end of the line of rushes, at the inlet of the lake. Captain B. was discouraged, but I, on the contrary, was elated - for I had olserved the dorsal fins of numerous bass in the shallow water hetween the rushes and the shore; and I had observed, further, that the bass were 
feeding on insects and flies which were being blown into the water by a brisk wind.

I proposed fishing back over the same ground to the evident disgust of the Captain. But I began casting between the bulrushes and the shore, in the shallow water under the lee of the bank, and fastened to a large bass at almost the first cast. The Captain followed my lead; and, on arriving at our original starting-point, a few hundred yards distant, we had taken fifteen fine bass. The three boats had made the entire circuit of the lake, and the six anglers in them, fishing on the usual grounds, had not, altogether, taken half as many fish, when they joined us for luncheon.

In lacustrine waters, black bass first appear in the shallowest portions, where the water is warm, and feed upon crustacea, mollusks, etc., retiring to deeper water as the season adrances. When the patches of rushes and other aquatic plants are well grown, they will be found near them, feeding on the ninnows and small fry which congregate there. When the ephemeral flies of early summer appear, the bass will then be found where these are most numerous; and they, at this time, feed at the surface.

I was once fly-fishing for bass in the Neenah Channel, at the outlet of Lake Winnebago, Wisconsin. The stream was quite swift, with a rocky bottom, and the surface was covered with May-flies, upon which the bass were feeding. I was enjoying royal sport, using a cast of two brown hackles, and frequently fastened a fish to each fly.

A boat-load of rustic anglers, with tamarack poles and short lines, seeing my success, dropped down abreast of me, and anchored within fifty feet of my boat. They were using small minnows for bait, with heary sinkers on their lines, which, of course, carried the bait to the bottom, where were feeding schools of white bass (Roccus chry- 
sops). As I took only black bass from the surface, they caught nothing but white bass at the bottom. They could not understand it, and I did not enlighten them, for I had no desire to see my pet fish "yanked out" by tamarack poles and tow strings. I left them, shortly, in the glory of "snaking out" - as they called it - the unfortunate white bass, wondering, meanwhile, why they could not catch black bass like "that other fellow."

But do we really know any of the conditions favorable or unfavorable for angling? We are told that fish will not bite when the water is rendered high and turbid by freshets; during a thunder-storm, with heary rain; on dark, cold days, with a blustering east wind; and on bright, still and hot days, when the water lies unruffled, like a burnished mirror. If this be so, it is extremely fortunate, and we can apply the rule of exclusion here, and at once dismiss all such occasions from further consideration; for I take it for granted that the reader has no desire to "go-a-fishing" at such times.

Fortunately, again, the season for angling is during pleasant weather, in spring, summer and autumn; and I have always observed that the pleasantest days for the angler's comfort, were usually the most propitious and successful days for angling.

It matters little, for bait-fishing, whether the day be bright or cloudy, or whether the wind is in the east, west, north, or south, so long as it is a pleasant wind, and is not too raw and chilly. I have had "good luck" with the wind in either quarter, and from a gentle breeze to half a gale; on days that were hot, bright, and cloudless, as well as on those that were cloudy and rather cool.

To be sure, it makes some difference as to the character of the waters; the pleasantest days are best for small 
streams and shallow waters, while the more unlikely days would better suit lakes and deep water's though in either case, the pleasantest days, in all respect, are the best.

The fish in deep waters are not so easily affected by the ricissitudes of weather, as those in waters of shallow depth. As exceptional cases I might add that I have had as good success with a reefing east wind, or a half-gale from the north-west, on lakes of good depth, as at, seemingly, the most favorable times.

Once, on La Belle Lake, at Oconomowoc, Wisconsin, I went fishing when the wind was blowing quite fresh from the west. I proceeded to the lower end of the lake, some three miles, when the wind suddenly hauled around to the north-west, blowing great guns, and causing the "whitecaps" to roll furiously. It was impossible to make headway against it, so I was compelled to anchor, which I did in a bight of bulrushes, in water from ten to twelve feet deep, but near a gravelly bar. Here I took, in a little more than two hours, twenty-five black bass, which afterward turned the scales at seventy-five pounds. I have always considered this catch as being one of the best I ever made. On my return, owing to the high wind and heavy sea, it was all I could do to keep my boat from swamping.

On another occasion, on Oconomowoc Lake, I. fished at a rocky bar, which divided the lake into two portions. The wind was blowing a half-gale from the east, and quite cool; the shallow water on the bar was churned and tossed into billows of seething foam by the high wind, enabling me to fish in water but a foot or two in depth; and in a short time I took nine bass, the smallest of which weighed four pounds.

Again, on Genesee Lake, in the same locality, I once 
made a good catch under peculiar circumstances. On this occasion I was "frogging," as this lake at that time was famous for the quantity and quality of its bull-frog.: After spearing a "good mess" of greenbacks, I was standing on a sand-bar, which divides the lake into two parts during low water, and was idly watehing the waves rolling up on the bar, which were being driven with great fury by a strong south-west wind. I chanced to see several black bass, evidently feeding in the surf; and I then began derising ways and means for their capture.

Near by, was a water-logged boat, in which I saw a tamarack pole, and, upon inrestigation. I found that there was a short line and hook attached. My plans were soon formed. I went to a small hole of water, that I had preriously olserved, which was left after the drying up of the outlet of a marsh at the lower end of the lake, and in which I had seen a great many small minnows, an inch or two long. Dipping up a lot in my handlicrchicf. I took it by the corners and proceeded along the shore, dipping up water occasionally to keep the bait alive. On the bar I scooped a hole in the sand for the hait, filled it with water and went to fishing. The norelty of the situation, and my curiosity as to the result of the experiment, quieted my conscience and justified the employment of such primitive measures. Baiting the hook, I waded into the surf as far as I could with ordinary boots - for, being carly in the season, the water was quite cold - I was soon pulling out the bass, and took in this manner, with a short pole and six feet of line, fifteen splendid bass.

In angling, it may be safely accepted as a truism, that any wind is better than no wind; a gale being better than a perfectly still day. especially when the water is clear. The reason for this is, that the surface of the water being 
agitated and ruffled by the breeze, the fish are not so apt to see the angler.

An east wind is popularly regarded as an unfarorable wind for fishing, but it is not necessarily so. The opinion is of English origin, for in the humid climate of Great Britain an east wind is exceedingly raw, chilly, and disagreeable, and is held to be productive of all manner of evils, being particularly dreaded by sufferers from rheumatism, neuralgia, or gout. The anglers of England, of course, share in this common detestation of an east wind, and this prejudice is clearly shown by British writers on angling, from whom most of our ideas on fishing were formerly derived.

But it is only after such a wind has prevailed for several days, so as to lower the temperature of inland waters, that it, in any way, affects the "biting" of fish. This, no doubt, is often the case in Great Britain, and has led to the erroneous supposition that an east wind, under any and all circumstances, is most unfavorable for the angler; and this idea has, to a great extent, been tacitly accepted to apply to our own country as well.

But unless the fish have an inherited traditionary remembrance of that "remarkable east wind" which divided the waters of the Red Sea and enabled Moses and his followers to pass over dry-shod, which causes them to become suspicious of erery east wind that blows, I can not conceive how it affects their feeding, except, as stated before, when it has been of sufficiently long continuance to cool the water.

Along the Atlantic coast of the United States an cast wind is generally held to be unpropitious for fishing; but in this case post hoc is mistaken for propter hoc; in other words, the effect is mistaken for the cause. After an un- 
usually long series of east winds, or easterly gales, the tides are much affected thereby, and rise much higher, and spread over more extensive surfaces. The fish, as a matter of course, take advantage of this state of aflairs, and extend their range in quest of food, being rewarder by great quantities of crustacea, mollusks, etc. which before were inaccessible on account of the shallow water. It such times, the fish are not found on their usual feerling grounds in the tideways. and hence has arisen the erronenus idea that they do not feed during an east wind.

Many hait-fishers have an abiding faith in the signs of the roliace in influencing the biting of fish: believing that when the "sien" is in the feet (Pisces), and also just hefore and after. encer aching on the domains of the leges (Aquarius), and head (Aries), that fish feel better than at other times. They, of course, always remember the surcessful oecasions at these periods. but soon forget. or imagine some satisfactory reason for, the failures; and thus their superstitious belief seldom weakens.

The monn. likewise, is supposed by many to influenee the feeding of fish. In Florida. the opinion is very prevalent among hunters and fishermen. that deer, fish, and other animals feed principally when the moon is above the horizon. night or day, particularly at moon-rise, moonsouth, and moon-set. This belief also obtains in other sections of our country, and the adherents to the theory are. withal. so consistent, that their faith ean not be shaken by repeated failures, and they seldom hunt or fish except when the "moon is right."

While I am not a believer in the theory of the moon's influence over terrestrial ohjects. I am not prepared to say that there is nothing whaterer in the moon affecting the feeding of fish; for while fish certainly feed mostly at 
night, they seem to feed more especially on moonlight nights. Still, I do not attribute this fact to any influence possessed by the moon beyond the light it affords to enable the fish to find their prey. I have often observed that during the season of full-moon, fish were more apt to be sluggish and off their feed during the day time; and this I have always attributed to the fact that they did their feeding mostly at nights, at such times. Many anglers only fish from the last quarter until the new moon - that is, during the "dark of the moon."

A perfect day for fishing might be described as a warm, pleasant day, with a balmy, invigorating breeze; a mellow sunlight, not too bright, produced by a somewhat hazy atmosphere, or by drifting clouds; when the season has been neither too wet nor too dry; such a day as makes it a pleasure for one to breathe, and inhale with delight the odors and fragrance of forest, field, and stream.

Not a day that produces a feeling of exquisite languor, and disposes to delicious, dreamy reveries, like the stimulant effect of an opiate; but a day when the atmosphere seems filled with some indescribable aerial stimulant, that acts upon the brain, nerves, and circulation like sparkling wine; that rouses the energies and spurs the nerves, pulses, and muscles to action; such a day as makes one desire to laugh, to sing, to leap, to caper, to race through the meadows, to indulge in sudden impulses, in short, to make one feel a boy again.

Such a day, when the water is semi-transparent or translucent, and of such a temperature when it is most pleasant to bathe in - such a day, I say, is sure to be a satisfactory one to the angler, and the fish will be pretty sure to bite.

On a day such as I have just described, I once made my largest catch of black bass, though I have always been 
opposed to "big catches," on principle; for I hold that when the sole object in angling is to eatch fish as long as they will "bite," the proceeding leares the province of sport, and degonerates into pot-fishing, or, what is worse, useless and unjustifiable slaughter; much in the same way that, when an unprincipled merchant, during the eivil war, took unfair adrantage of certain circumstances, and sold goods at an adrance of five hundred per cent., and who, when afterward boasting of the fine per centage of profit realized, was told by a plain-spoken old gentleman that the transaction passed the limits of per centage and entered the bounds of petit larceny.

But as an honest confession is good for the soul, I will relate the incident referred to: I was fishing in Okauchee Lake, Wisconsin, jn company with two friends from Cincimnati, on a really perfect day in July. Mre had, unfortumately, a bountiful supply of fine minnows for bait, and aifer we had taken more than enough fish. I proposed to stop; but my friends, to whom the experience was new, could not be induced to relinquish the exciting sport, so I continued fishing, under protest, and we took during the day one hundred and fifty-three bass, and, with shame do I confess it, more than one-half - I am afraid to say just how many more - fell to my rod.

In justice, however, but not as a redeeming feature, I will state that the fish were not wasted, for a hundred fine bass were packed in ice and expressed to friends in Cincinnati, and the balance were distributed among the hotels of Oconomowoc.

I always look back upon this circumstance with regret, though I have done penance for the transaction, many a time and oft, since, by stopping at a dozen bass, when I might have taken twice the number. 
Some anglers tell us that fish will not bite before a rain; others say they will not take a bait during a rain; and still others affirm that it is useless to fish after a rain. Now, while there is a grain of truth in each of these opinions, yet if we blindly accept all of them and endeavor to follow them, we shall have no further use for our fishing-tackle.

I do not think that rain, per se, has any influence whatever upon the feeding of fish. It is, of course, impossible for us to judge in this matter by a comparison with terrestrial creatures; but, fishes being inhalbitants of the watery clement, it is not reasonable to suppose that a rain makes any difference with them at all, at the time, though they profit or not by the subsequent rising and roiling of the water.

The multitudes of insects which are said to be beaten down from the overhanging trees and from the air into the water, during a shower of rain, must be taken cum grano salis; for insects, like most other mundane creatures, know enough to "come in out of the wet." Te really find no more insects floating on the water during a rain, than at other times, though it is true that many are collected and swept by rains from the surface of the ground, and washed into the streams by swollen brooks and branches; but with the insects, go, also, the washings, debris, and particles of soil to discolor and thicken the streams, so that the fish may really fast in the midst of plenty, not being able to see the sudden influx of food by reason of the turbicity of the water; and, again, it is doubtful if fish feed much on dead insects.

The fish, howerer, on the other hand, are enabled to extend their range in foraging for food, during freshets, when the water has cleared sufficiently to allow them to discover it. 
I have noticed that fish usually bite better just before a shower; especially if the weather be murky and warm, and I think this can be accounted for in this way: It is generally quite calm, for a longer or shorter time previous to a summer shower, and the water being still, the fish do not bite, as they see the angler too distinctly — and this is why some have said that it is not a good time to fish before a rain - but immediately preceding the shower, a brisk breeze usually springs up, rippling the water, and it is at this time that fish seem to become possessed with a sudden impulse to feed. not on account of the impending rain, however, as many suppose, but because the angler is hid from view by the ruftling of the water. Sometimes this breeze accompanies the rain, and at other times follows the rain, and in either case the fish will bite best while the breeze continues. When a shower is followed by a calm, fish, of course, will not bite, in clear water, and as this often happens, it follows that some anglers hold to the opinion that they never bite after a rain.

I have tried to impress the reader, all through this chapter, with the importance of keeping out of sight of the fish as much as possible, for therein lies the greatest secret of success in angling; and fish will be found to bite better, alwars, when conditions are such as to faror the screening of the angler from their erer-watchful eyes, and, when, at the same time, the water is sufficiently clear to enable them to discern the bait on or beneath the surface.

In fly-fishing, especially, must this caution be exercised to its fullest extent, for the casts being necessarily much shorter than in bait-fishing. the angler is more liable to be seen; and herein lies the foundation of the opinion, entertained by many, that black bass are more uncertain to rise to the fly than the brook trout. I hold that black bass, 
during the proper scason, will rise as readily to the fly, under the same conditions, as the trout.

But the fact is, that while the bass is as wary as the trout, he is not so timid. The trout darts away at the first glimpse of the angler. while the bass will hold his ground, though ready to depart unceremoniously when occasion calls, eyeing the angler meanwhile, and entirely ignoring his best skill, though he cast his feathery lures never so lightly and naturally. The bass is too knowing to be taken in by any such deception so long as he sees the angler at the other end of the rod; hence, more caution is really necessary in fly-fishing for black bass than for the brook tront.

In regard to the best time of day for angling, there is not much choice, and it is governed a good deal by the scason of the ycar, the temperature of the water, and by the character of the day itself, thongh, as a rule, fish are sluggish and off their feed during the middle of the day, with a bright and warm sun, say from noon until three oclock, except early and late in the season, when the water is still cold, when the middle of the day is often the best time.

For bait-fishing, on small streams, the early morning hours, about sunrise, are often the best; though on large streams and lakes there is nothing gained by early fishing, as the fish do not bite well until the sun is several heurs high.

The latter part of the afternoon, until sundown, is often the best part of the day for the angler. On cloudy days, howerer, the middle of the day is often the most favorable, especially if the weather is rather cool.

For fly-fishing, the m.n morning hours succeeding sunrise, and from an hour or two before sunset until dark, or 
with a nearly full moon, even later. will be found the best hours for filling the creel.

Of course, all of these times must be gorerned by conditions of the wind, weather, and water, whether farorable or not; for no matter what the hour of the day, it will be the most successul, when other conditions are most farorable, and approach more nearly to the "typical" day for angling, as described in this chapter, the most prominent features of which are pleasant weather, translucent water, and a fresh breeze.

Thunder, and electrical conditions of the atmosphere, I lave out of the areount altogether, as we hare no means of judging of the influence of so subtile an agent as electricity on the fimny tribe: nor have I ever observed any peculiar effect on fishes from these causes, though great -tress is often laid by some anglers on the influence of an atmosphere surcharoed with electricity, whatever that may mean: but it is no more reasonalole to suppose that fishes would be disturbed by olectrical conditions of the air, than terrestrial animals would be inconvenienced or otherwiso by clectric conditions of water.

But, notwithstanding all of our patient and careful observations of the habits of fish, their food and their surroundings, and our study of the various couclitions of wind, weather. and water, there will be tass and dass in the experienee of every angler, when the fisly will utterly rofuse to bite: and this nn such days as the most finished, practices, and olservant angler would pronounce exceedingly favorable in erory particular. At such times one is forcibly reminder of the analogy existing between the will of woman and the "l,iting" of fish, as related in the familiar lines:

"For if she will, she will, you may depend on't; And if she won't, she won't: so there's an end on't." 
Every black bass angler has seen - where the water was clear enough for observation - the bass seize his minnow through seemingly mere caprice, and, insteacl of attempting: to gorge it, would take it gingerly by the tail, toy with it, and finally eject it, or spit it out, as it were; and this would be repeated sereral times in succession, or unitil the angler's patience became exhauster, when, while unjointing his rod, he would muse upon the waywardness of fish in general, and would he convinced that Solomon never went a-fishing, or he would have added another item to the four things ton wonderful for his ken, or at least have substituted "the way of a fish with a bait," for the less puzzling proposition of "the way of a man with a maid." 


\section{CHAPTER XX.}

\section{THE BLACK BASS AS A GAME FISH.}

"He is a fish that lurks close all winter; but is very pleasant and jolly after mid-April, and in May, and in the hot months." IZAAK WALTON.

Tirose who have tasted th: lotus of salmon, or trout fishing, in that Ltopian clime of far away - while reveling in its asthetic atmosphere, and surrounded by a misty halo of spray from the waterfall, or enveloped by the filmy gauze and irideseent haze of the cascade - have inscribed trmes, sang idyls. (hanted paxans, and poured out libations in honor and praise of the silver-spangled salmon, or the ruby-studeled trout, while it is left to the vulgar horde of black bass anglers to stand upon the mountain of their awn doubt and presmption, and. with uplifted hands. in admiration and awe, saze with datzed "yes from afar upon that forbidilen land - that lerre incongle - and then, having lived in vain, die and leave no sign.

It is, then, with a spirit of rank heresy in my heart; with smoked glass suectacles on my nose, to dim the glam and glamour of the tramsermelent shore; with the scales of justice across my shonleler - M. selmoides in one seopl and $M$. dolomion in the other - I pass the barriers and confines of the enchanter? land, and toss them into a stream that has been depopulated of eren fingerlings. by the dilettenti of salmon and trout fishers: for I would not, eren here, put hlack basi in a stream inhabited ly salmon or brook trout.

While watching the plebeian interlopers sporting in an 
eddy, their bristling spines and emerald sides gleaming in the sunshine, I hear an awful voice from the adjacent rocks exclaiming: "Fools rush in where angels fear to tread!" Shade of Iraak Walton defend us! While appealing to Father Izaak for protection, I quote his words: "Of which, if thou be a severe, sour complexioned man, then I here disallow thee to be a competent judge."

Seriously, most of our notions of game-fish and fishing are derived from British writers; and as the salmon, the trout and the grayling are the only fishes in Freat Britain worthy of being called game, they, of course, form the themes of British writers on game-fish. Americans, following the lead of our British cousins in this, as we were wont to do in all sporting matters, have eulogized the salmon and brook trout as the game-fishes par excellence of America, ignoring others equally worthy.

While some claim for the striped bass a high place in the list of game-fish, I feel free to assert, that, were the black bass a native of Great Britain, he would rank fully as high in the estimation of British anglers as either the trout or the salmon. I am borne out in this by the opinions of British sportsmen whose statements have been received without question.

II. H. Herbert (Frank Forester) writing of the black bass, says:

"This is one of the finest of the American fresh-water fishes; it is surpassed by none in boldness of biting, in fierce and riolent resistance when hooked, and by a very few only in excellencs upon the board."

Parker Gilmore ("Ubique") says:

"I fear it will be almost deemed heresy to place this fish (black bass) on a par with the trout; at least, some such ideil I had when I first heard the two compared; but I am bold, and 
will go further. I consider he is the superior of the two, for he is equally good as an article of food, and much stronger, and untiring in his efforts to escape when hooked."

Now, while salmon fishing is, unquestionably, the highest branch of piscatorial sport; and while trout fishing in Canada, Naine, and the Lake Superior region justifies all the extravagant praise bestowed upon it, I am inclined to doubt the judgment and good taste of those anglers who snap their fingers in contempt of black bass fishing, while they will wade a stream strewn with brush and logs, eatch a few trout weighing six or eight to the pound, and call it the only artistic: angling in the world! While they are certainly welcome to their opinion, I think their zeal is worthy of a better cause.

The black bass is eminently an American fish, and has been said to be representative in his characteristics. He has the faculty of asserting himself and making himself completely at home wherever placed. He is plucky, game. brave and morelding to the last when hooked. He has the arrowy rush and vigor of the trout. the untiring strength and hold leap of the salmon, while he has a system of fighting tactics peculiarly his own.

IIe will rise to the artificial fly as readily as the salmon or the brook trout. under the same conditions; and will take the live minnow, or other live bait, under any and all cireumstances favorable to the taking of any other fish. I consider him, inch for inch and pound for pound, the gamest fish that swims. The royal salmon and the lordly trout must yicld the palm to a black bass of equal weight.

That he will erentually become the leading game-fish of Amerien is my oft-expressed opinion and firm belief. This result, T think, is ineritable; if for no other reasons, from a force of circumstances occasioned by climatic con- 
ditions and the operation of immutable natural laws, such as the gradual drying up, and dwindling away of the small trout streams, and the consequent decrease in brook trout, both in quality and quantity; and by the introduction of predatory fish in waters where the trout still exists.

Another prominent eause of the decline and fall of the brook trout, is the erection of dams, saw-mills and factories upon trout streams, which, though to be deplored, can not be prevented; the march of empire and the progress of civilization ean not be stayed by the honest, though powerless, protests of anglers.

But, while the ultimate fate of the brook trout is sealed heyond peradrenture, in open, public waters, we have the satisfaction of knowing that in the black bass we have a fish equally worthy, both as to game and edible qualities, and which at the same time is able to withstand, and defy, many of the causes that will, in the end, effect the annihilation and extinction of the brook trout.

As to a comparison of game qualities as between the small-mouth bass and the large-mouth bass, I hold that, other things being equal, and where the two species inhabit the same waters, there is no difference in game qualities: for, while the small-mouth is probably morn actire in its movements, the large mouth bass is more powerful; and no angler can tell from its manner of resistance whether he is fast to one or the other.

But what are the game qualities of a fish? As I understand it, they are: its aptitude to rise to the artificial fly. its readiness to take a natural bait, its exhibition of strength and cunning. persistence and activity, in its efforts to break away after being hooked, and its excellence as a food-fish.

Both species of black hass rise equally well to the artificial fly; though, if there be any difference in this respect, 
I think the large-mouth bass has the advantage. In a letter from Count Ton dem Borne, of Germany (who was very successful in introducing and propagating the black bass in that country), he wrote me that the large-mouth black bass rose better to the artificial fly than the smallmouth bass. My own experience rather favors this view, and it has likewise been brought to $\mathrm{my}$ notice by anglers in various parts of the country.

The eurrent but erroneous opinion that the small-mouth bass exceeds the large-mouth bass in game qualities, has been very widespread, and has been much enhanced by the indorsement of several of our best ichthyologists, who unfortunately, howerer, are not, and do not pretend to be, anglers, but who imbibed this opinion second-hand from prejudieed anglers who ought to have known better. But as the black bass is becoming better known, and fly-fishing for the species is being more commonly practiced, this unfair and unmerited comparison is fast dying out.

Fish inhabiting swiftly-rumning streams are always more rigorous and gamy than those in still waters, and it is probable that where the large-mouth bass exists alone in rery shallow and sluggish waters, of high temperature and thickly grown with alga: it will exhibit less combative qualities, ennequent on the enerrating influences of its environment; but where both species inhabit the same waters, and are subject to the same conditions. I am conrinced that no angler ean tell whether he has hooked a large-mouth or a small-mouth hass, from their resistance and mode of fighting. provided they are of equal weight, until he has the ocular evidence.

I use the expression "equal weight" arivisedly, for most anglers must have remarked that the largest bass of either species are not necessarily the hardest fighters; on the 
contrary, a bass of two or two and a half pounds weight will usually make a more gallant fight than one of twice the size, and this fact, I think, will account in a great measure for the popular idea that the small-mouth bass is the "gamest" species for this reason:

Where the two species co-exist in the same stream or lake, the large-mouth bass always grows to a larger size than the other species, and an angler having just landed a two pound small-mouth lass after a long struggle, next hooks a large-mouth bass weighing four or five pounds, and is surprised, probalsy, that it "fights" no harder or perhaps not so hard as the smaller fish - in fact, seems "logy;" he, therefore, reiterates the cry that the smallmouth bass is the gamest fish.

But, now, if he next succeeds in hooking a largemouth bass of the same size as the first one caught, he is ccrtain that he is playing a small-mouth bass until it is landed, when to his astonishment it proves to be a largemouth bass: he merely says, "he fought well for one of his kind," still basing his opinion of the fighting qualities of the two species upon the first two caught.

Perhays his next eatch may be a small-mouth bass of four pounds, and which, though twice the weight of the large-mouth bass just landed, does not offer any greater resistance, and he sets it down in his mind as a largemouth bass; imagine the angler's surprise, then, upon taking it into the landing net. to find it a small-mouth bass, and one which, from its large size and the angler's preconceived opinion of this species should have iought like a T'rojan.

Now, nne would think that the angler would be somewhat staggered in his former belief; but no, he is equal to the occasion, and in compliance with the popular idea, he 
merely suggests that "it was out of condition, somehow," or "was hooked so as to drown it early in the struggle;" and so, as his largest fish will necessarily be big-mouth bass, and because they do not fight in proportion to their size, they are set down as lacking in game qualities - of course, leaving the largest small-mouth bass out of the calculation.

Gentle reader, this is not a case of special pleading, nor is the angler a creation of the imagination lugged in as an apologist for the large-mouth bass; he is a veritable creature of flesh and blood, of earth earthy, and with the sclf-conceit, weaknesses and shorteonings characteristic of the genus homo. I have met him and heard his arguments and sage expressions scores of times, and if the reader will reflect a moment I am sure be will recognize him.

Many years ago I was at Gogel,ic Lake, Wisconsin, where, among a number of prominent anglers. were Dr. F., and Dr. T., both of New York City. Dr. F. had a very extensive angling experience in all parts of the country, and i)r. 'T. Was well known as a participant in the fly-and bait-casting contests in the tommaments of the National Rod and Reel Association of that day.

Dr. F. was a firm believer in the superior game qualities of the small-mouth bass, and declared that he could inrariably tell what species of black bass he had hooked, from its mamner of " fighting:" Dr. 'T. was confident he could not do so. The matter was finally put to a practical test, when Irr. F. was forced to acknowledge himself vanquished, and that he nor any other angler could make the distinction, for one fish was as "gamy" as the other. I might add that this result will be obtained wherever the two species exist in the same waters. 
Mr. S. C. Clarke, a veteran angler of sixty years' experience, and whose opinion is entitled to great weight, says:

"I will say that, from an acquaintance with both species for more than forty years, from Minnesota to Florida, I hare found little or no difference between them. I have taken them with fly, spoon, and bait, as many as fifty in a day (in early times), and up to six and a half pounds weight."

A few years before his death, Fred Mather wrote as follows:

"A bad name, given to the big-mouth when black bass first began to attract the attention of anglers, has stuck. It may interest a younger generation of anglers to know that forty years ago these gamy fishes were hardly known to anglers, and as soon as they began to attract attention some persons, to show their exquisite discrimination, began to praise one to the detriment of the other. Dr. Henshall and I have had the courage to fight this, and to say that in game qualities there is little difference, and that what there is depends on the weight of the fish, two pounds being its fighting weight. Further than to say that the big-mouth is not so capricious about taking the fly as his brother-i. e., will usually take it more freely-I have not room to go into this subject here. I have written all this before and intend to keep at it until justice is done to a noble gamefish."

Mr. Henry Talbott, an angler of wide experience, and who has written so entertainingly and instructively on black bass angling in the Potomac, says:

"There are some anglers who consider there is but one black bass, the small-mouth, and that the other is useless for food, lacking in gamy qualities and only fished for by the misguided. In this they are mistaken, and it is a theory they will abandon and resent when their experience is wider.

"It is possible that in the Florida lakes they may be tame sport, and there seems to be a general agreement that in some 
of the swamps of Ohio the big-mouth is an inferior fish, but there is yet to be found his superior where he has a fair chance.

"Taking the two fish at their best, there is no man living can tell the difference in their taking the fly, in their fight to the boat, or on the platter, by any other sign than that one has a more capacious smile than the other; and by the same token he is just a little the better jumper and will leave the water oftener after being hooked, and is as long in coming to the net as his cousin."

Owing to my admiration for the black bass as a gamefish, and my championship of its cause for many years, and my efforts to place it in the front rank of game-fishes, and my desire to have it placed in new waters, I am sometimes, thoughtlessly and unjustly, aceused of being opposed to thr brook trout, and of advising the stocking of trout streams with my "favorite" fish. Nothing can be further from the truth.

I am utterly opposerl to the introduction of black bass into waters in which there is the remotest chance for the brook trout or rainbow trout to thrive. I yicld to no one in lowe and admiration for the brook trout. I was perfectly familiar with it before I ever saw a black basis; but I am not so blinded by prejudice but that I can share that love with the black bass, which for several reasons is de:tined to beeome the favorite anme-fish of America. "My offending hath this extent, no more."

Let us look this thing squarely in the face. I to not wish to disturb any one's preference. but I do want to disabuse the minds of anglers of all prejudice in the matter. The brook trout must go. It has already gone from many streams, and is fast disappearing from others. It is sad to contemplate the extinction of the "angler's pricle" in public waters. but the stern fact remains that in this utilitarian age its days are numbered and its fate irrevocably sealed. 
As the red man disappears before the tread of the white man, the "living arrow" of the mountain streams goes with hin.

The trout is essentially a creature of the pine forests. Its natural home is in waters shaded by pine, balsam, spruce and hemlock, where the cold mountain brooks retain their low temperature, and the air is redolent with balsamic fragrance; where the natural food of the trout is produced in the greatest abundance, and where its breeding grounds are undisturbed.

But the iron has entered its soul. As the buffalo disappears before the iron horse, the brook trout vanishes hefore the axe of the lumberman. As the giants of the forest are laid low, and the rank and file decimated, and the wooden walls of the streams battered down, the hot, fiery sun leaps thrcugh the breaches, disclosing the most secret recesses of forest and stream to the bright glare of mid-day. The moisture of the earth is dissipated, the mosses and ferns hecome shriveled and dry, the wintergreen and partridgeberry, the ground pine and trailing arbutus struggle feebly for existence; the waters decrease in size and increase in temperature, the conditions of the food supply and of the breeding grounds of the brook trout are changed; it deteriorates in size and numbers and vitality, until finally, in accordance with the immutable laws of nature and the great principle of the "survival of the fittest" (not the fittest from the angler's point of view, but the fittest to survive the changes and mutations consequent on the march of civilization), it disappears altogether.

Much has heen said about the "trout hog" in connection with the decrease of the trout. But while he deserves all the odium and contempt heaped upon him by the honest angler, the result would be the same were the trout allowed 
undisturbed and peaceable possession of the streams, so far as the fish-hook is concerned, while the axe of the lumberman continues to ring its death knell.

Let us, then, cherish and foster and protect the crimsonspotted farorite of our youthful days as long as possible in public waters, and introduce the rainbow trout, the Dolly Tarden, the steelhead, the red-throat trout or the English lorown trout, when he has disappeared; and when all these succuml,, then, and not till then, introduce the black bass. But let us give these cousins of the brook trout a fair trial first. and without prejudice. There are plenty of lakes, ponds and large streams in the eastern states into which the black bass can be introduced without interfering with trout waters.

For many years to come brook trout will be artificially cultivated, and the supply thus liept up in preserved waters by wealthy angling clubs; but by the alteration of the natural conditions of their existence they will gradually decrease in size and quality, until finally they will either cease to be or degenerate to such a degree as to forfeit eren this praiseworthy protection.

I must dissent from the statement sometimes made that the black bass is the bluefish of fresh waters. The black bass is voracious-so are all game-fishes-but not more so than the brook trout. The character of a fish's teeth determines the nature of its food and the manner of its feeding. The bluefish has the most formidable array of teeth of any fish of its size - compressed, lancet-shaped, covereri with cnamel, and exceedingly strong and sharp, in fact, miniature shark teeth - while the black bass has soft, small, brush-]ike teeth. incapable of wounding, and intended only for holding its prey, which is swallowed whole. The brook trout has longer, stronger and sharper teeth than 
the bass, and a large, long mouth, capable of swallowing at bigger fish than a black bass of equal weight. The mouth of the bass is very wide, for the purpose of taking in crawfish with their long and aggressive claws, and not, as supposed by some, for the swallowing of large fishes. The black bass gets the best of other game-fishes, not by derouring the fishes themselves, but by devouring their food. For this reason, more than any other, they should not be introduced into the same waters with brook trout. The pike or pickerel is the bluefish of fresh waters, and in dental capacity and destructive possibilities is not far behind it.

The brook trout. I think, is the most beautiful of all fishes, as a fresh-run salmon is the handsomest and most perfect in form. The salmon is a king, the brook trout a courtier, but the black bass, in his virescent cuirass and spiny crest, is a doughty warrior whose prowess none can gainsay.

I have fished for brook trout in the wilds of Canada, where a dozen would rise at every cast of the fly, and it would be a scramble as to which should get it - great lusty trout, from a half pound to two pounds in weight - but the black fly made life a burden by day, and the mosquito by night. The glory and beauty of the madly rushing stream breaking wildly orer the great black rocks, and the quiet, glassy pools below reflecting the green spires of spruce and fir, availed nothing to the swollen eyelids and smarting brow.

I have cast from early morn till dewy eve, on a good salmon stream in New Brunswick, for three days in succession without a single rise. I have cast standing in a birch-bark canoe until both arms and legs were weary with the strain, and then rested by casting while sitting - but all in vain. The swift-flowing, cristal stream reflested back the fierce 
glare of the northern sun, and flowed on in silence toward the sea. The fir-clad hills rose boldly on either side, and stood in silent, solemn grandeur - for neither note of birel nor hum of bee disturbed the painful silence of the Canadian woods.

At such times would flash on memory's mirror many a fair scene of limpid lake or rushing river, shadowed by cool, umbrageous trees, and rocal with myriads of voices where the black bass rose responsive to the swish of the rod and dropping of the fly. Or. should the bass be coy and shy, or loth to leave his lair beneath some root or shelving rock - the melody of the hirds, the tinkle of a cow-bell, the chirp of a cricket, the scudding of a squirrel, filled up the void and made full compensation.

The true anglor can find real pleasure in catching little sunfish, or silversides, if the stream and birds, and bees and butterflies do their part by him; while the killing of large or many fish, eren salmon or trout, in silence and solitude, may fail to fully satisfy him.

I can find something beautiful or interesting in every fisin that swims. I have an abiding affection for erery one, from the lowly, naked bull-head, the humble savenger of the waters, to the silver-spangled king who will not deign to soil his dainty lips with food during his sojourn in crystal streams, and I love the hrook trout hest of all. But, as an angler. I can find more true enjoyment, more blessed peace, in wading some rushing. rocky stream, flecked by the shartows of overhanging elm and sycamore, while tossing the silken gage to the linight in Lincoln-green, my ears conscious of the rippling laughter of the merry stream, the joyous matin of the wondland thrush, the purring undertone of the quirering leaves - my eyes catching glimpses of hill and meadow, wren and robin, bee and bittern, fern 
and flower, and my breath inhaling the sweet fragrance of upland clover and elder-blossom - I say I can find more true enjoyment in this - than paying court to the lordly salmon, or the lovely trout, in its stiff and silent demesne, with anointed face, gloved hands, and head swathed in gauze. If this be treason, my brother, make the most of it. I am content. It is my honest conviction. After killing erery species of game-fish east of the Rocky Mountains, from Canada to Florida, and some in foreign lands, I find the knightly bass and his tourney-field all sufficient.

\section{THE CAPTURE OF THE BASS.}

My brother of the angle, go with me This perfect morning in the leafy June, To yonder pool below the rapid's foot.

Approach with caution; let your tread be soft;

Beware the bending bushes on the brink.

Disturb no branch, nor twig, nor leaf, my friend, The finny tribe is wary.

\section{Rest we here.}

Behold the lovely scene! The rippling stream, Now dancing, sparkling, in the morning sun;

The blue-eyed violet nodding at your feet;

The red-bird, all ablaze, with swelling throat, Chants loud his song in yonder thick-set thorn. The dreamy, droning hum of insect wings Is mingled ever with the rustling leaves. Sleek, weel-fed cattle there contented stand, On gravelly shoal beneath the spreading beech. Across the narrow stream a sycamore, A weather-beaten giant, old and gray, With searr'd arms stretching o'er the silent pool, With gnarl'd and twisted roots bathed in the flood For, lo, these hundred years. 
Beneath those roots

With watchful eye-proud monarch of the poolA cunning bass doth lie, on balanced fin, In waiting for his prey.

And now with rod,

With faithful reel, and taper'd line of silk, With mist-like leader and two fairy flies Dark, bushy hackles, both - I make a cast. With lengthen'd line I quickly cast again, And just beneath the tree the twin-like lures As gently drop as falling autumn leaves; And half-submerged, like things of life they seem, Responsive to the rod and line.

But look!

Saw you that gleam beneath the flood? A flash A shadow - then a swirl upon the pool?

My hand, responsive to the sudden thrill, Strikes in the steel - the wary bass is hooked! And now with lightning speed he darts away To reach his lair - his refuge 'neath the roots. The singing reel proclaims him almost there I "give the butt" - the ever-faithful rod In horse-shoe curve now checks his headlong flight. Right lustily he tugs and pulls, Egad! But still the barb is fast.

\section{The hissing line -}

The rod now bending like a slender reed

Resist's the tight'ning strain. He turns his courseIn curving reaches, back and forth, he darts, Deseribing ares and segments in the pool. Ha! nobly done! as with a mighty rush He cleaves the crystal stream, and at one bound, Full half a fathom in the realm above He nimbly takes an atmospheric flight His fins extended, stiff with bristling point's His armor brightly flashing in the sun- 
His wide-extended jaws he shakes in rage To rid him of the hook.

\section{And now I lower}

The pliant rod in court'sy to the brave.

The line relieved, somewhat, of steady strain, Outwits the wily bass - the hook holds fast!

Now back again he falls with angry splash To seek the aid of snag, or root of tree; For thus, my friend, he oft escapes, I trow, By fouling line or hook -

He never sulks!

Not he; while life remains, or strength holds good, His efforts never cease. Now up the stream Now down again - I have him well in hand. Now reeling in, or erstwhile giving line; He swims now fast or slow - now high or low. The steady strain is still maintained, you see! The good rod swaying like a wind-blown rush He surges thro' the flood.

\section{Another leap!}

Ye Gods! How like an angry beast he shakes His bristling mane, and dive's below again! And did you mark, my friend, his shrewd intent, As when he fell upon the slacken'd line? If then he'd found it stretched and taut, I ween, He would have made his safe and sure escape. But haply then the tip was slightly loweredAnd so, with yielding line, the hook held fast. Now truly, friend, he makes a gallant fight! In air or water - all the same to him His spiny crest erect; he struggles still. No sulking here! but like a mettl'd steed He champs the bit, and ever speeds the best With firm-held, tighten'd rein.

\section{He's off again!}

Now down the stream he flashes like a shaft

From long-bow swiftly sped - his last bold spurt - 
The effort cost him dear-his worsted strength Is ebbing fast. And now in lessening curres He feebly swims, and labors with the tide. And as I reel the line he slowly yields, And now turns up his breast-plate, snowy whiteA vanquished, conquered knight.

\section{And now my friend}

The landing-net. With firm and cautious hand Beneath the surface hold it. Take him in. Now lift him out and gently lay him down. How bright his tunic, bronze and glossy green! A fitting rival to the relvet sward. And see the ragged rent the hook hath made! You marvel how it held him safe and fast! Twas by the equal and continual strain Of supple rod and ever-faithful reel. 'Twas work well done.

\section{Oh. valiant, noble bass!}

Fit dweller of the merry, brawling stream. Thy once-loved pool beneath thy giant tree, Thy fancied stronghold 'neath its tangled roots, Shall know thee never more. Thy race is run!

Now in thy ereel,

My doubting friend, we'll gently lay him down Upon a bed of cool and graceful ferns, Yet sparkling with the early morning dew A warrior in repose! 

Copyright, $188_{3}$, by The Century C $\mathrm{O}$.

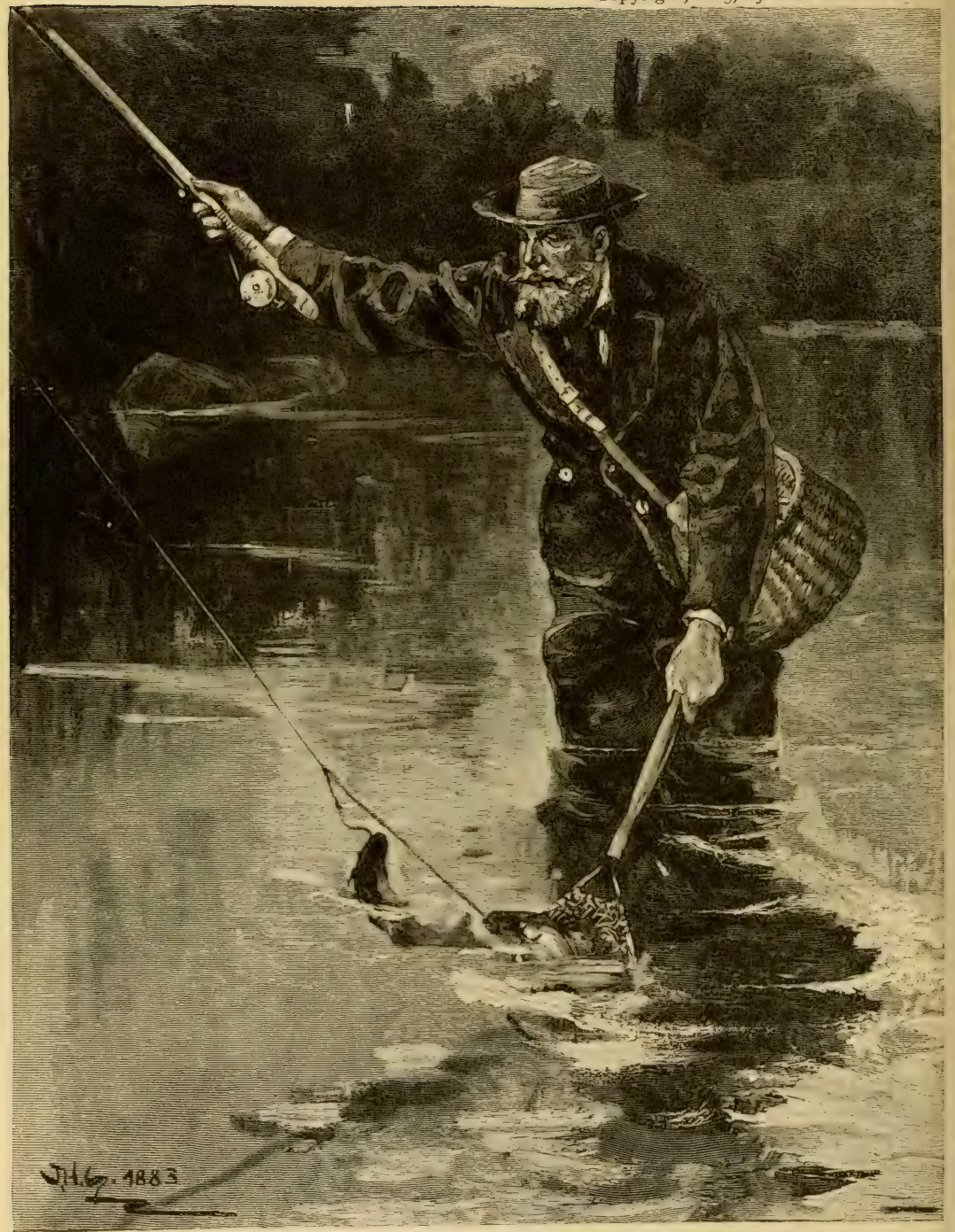

LANDING A DOUBLE CATCH. 


\section{CHAPTER XXI.}

\section{FLY-FISHING.}

"And now, scholar, my direction for fly-fishing is ended with this shower, for it has done raining."-IzAAK WALton.

Artificial FLi-fishing is the most legitimate, scientific and gentlemanly mode of angling, and is to be greatly preferred to all other ways and means of capturing the finny tribe. It requires more address, more skill, and a better knowledge of the habits of the fish and his surroundings than any other method.

Fly-fishing holds the same relation to bait-fishing that poetry does to prose; and, while each method will ever have its enthusiastic admirers, only he who can skillfully handle the comely fly-rod, and deftly cast the delicate fly, can truly and fully enjoy the æsthetics of the gentle art. As the lover naturally "drops into poetry" to express the ardent feelings of his soul, "with a woful ballad made to his mistress' eyebrow," so the real lover of nature and the finny tribe as naturally takes to fly-fishing, and finds liquid poems in gurgling streams, and pastoral idyls in leafy woods.

A friend in Texas, to whom I sent a bass-fly and who had never seen an artificial fly before, enthusiastically declared it to be "a fish-hook poetized," and thought that a "black bass should take it through a love of the beautiful, if nothing else." Not only the fly, but every implement of the fly-fisher's outfit is a materialized poem.

Fly-fishers are usually brain-workers in society. From time immemorial the fraternity has embraced many of the 
most honored, intellectual and cultured members of the liberal professions and arts. Along the banks of purling streams, beneath the shadows of umbrageous trees, or in the secluded nooks of charming lakes, they have ever been found, drinking deep of the invigorating forees of nature, giving rest and tone to overtaxed brains and wearied nerves, while gracefully wielding the supple rod, the invisible leader, and the fairy-like fly.

Oh! how the sluggish pulses bound, the deadened nerves thrill, and the relaxed muscles quicken, responsive to the inspiration of the electric rise of the gamy denizens of the stream; and oh. how the buried forces of life are resurrected, renewed and strengthened by the hopes, and fears, and struggles, of the contest which follows! And when at last the brave beauty has heen lovingly deposited in the creel, the restored angler feels that he has wom a double victory; for, in the death of the fish, he sees renewed life for himself.

But the true fly-fisher, who practices his art con amore, does not delight in lige catches, nor revel in undue and cruel slaughter. IIe is erer satisfied with a molerate creel. and is content with the scientific and skillful capture of a few grood fish. The beauties of nature, as revealed in his surroundings - the sparkling water. the sharlow and sunshine, the rustling leares. the song of birds and hum of insects, the health-giving loreeze - make up to him a measure of true enjorment, and peace, and thankfulness, that is totally unknown to the slaughterer of the innocents, whose sole ambition is to fill his ereel and record his captures by scores, and who realizes naught in his surroundings but the hot sun, slippery rocks, haffling winds, and the amnoyance of orerhanging trees and bushes. The time is coming when such an angler will receive, as well as merit, the 
scorn and contempt of all good and true disciples of the gentle art.

The literature of hlack bass fishing may truly he said to have heen evolved during the past thirty yar's. P'revinus to this period very little mention was made of the two species of black bass by our angling authors, and that little wat misleading. ineorect or glaringly false in most instanceand related, almost without exception, to bait-fishings. Fly-fishing for black bass. although then practiced hy a few angler's, was a d) a rently unknown to writers on angling. Indeed, it was doulsted liy many, and denied ly most anglers, that the black bass would rise to the artificial fly; but this. in my opinion. Was due more to prejurlice than to the result of actual experience, and viewed in the light of our present knowledge of the sulject, this opinion is extainly strengthened, if not confirmed.

Up to that time the brook trout was deservedly the pride and idol of the fly-fisher. and it was deemed heresy to east the fly for any other fish, with the exception of the salmon. But while vielding to none in my love and admiration for the brook trout. I regard it as a matter of justice for me to state that, in my opinion (based on a large experience), there are no waters inhal,ited by the hlack bass, large- or small-mouth, where it will not rise to the artificial fly at some scason of the rear. sulject to certain states and conditions of the water, ete. and this is much as can be said for the brook trout as all unprejucliced trout-fishers must admit.

It is true that the black hass rises to the fly more freely and uniformly in some waters than in others, but this fact holds good also as to the hronk trout. Ind likewise is it a truism. that the largest fish, trout or hass. do not. as a rule, take the artificial fly. Those who wish to lure the finny 
giants must perforce use bait or the trolling-spoon. This is a damaging admission to our piscatorial pride, but candor compels us to acknowledge the correctness of it, though we may find some guility consolation or quasi-satisfaction in exhibiting the huge piscine trophies to our admiring and credulous friends with the usual remark: "Caught on the fly! ”

Seriously, it is entirely unnecessary, at this late day, to argue that the black bass will or will not rise to the artificial fly. The fact is now known to most anglers, and conceded by others, that the black bass is a game-fish of high degree, and when of equal weight is the peer of the brook trout or salmon in fighting qualities. when proper tackle is employed, and will rise to the fly under the same favorable conditions.

In order to be successful in fly-fishing for black bass, the angler must know the waters to be fished, or be possessed of that knowledge of the haunts and hahits of the bass that is loorn only of much experience. Ife must know when and where the fish are to be found at the different seasons of the year; when they frequent deep, and when shallow water, for it is love's labor lost to cast the fly on deep, still reaches of water.

In stream fishing. which is by far more preferable and enjoyalule than lake or jomd fishing, it is only when the bass are on the shallows or on the riffles that the fly-fisher will fill his creel, and on lakes when they frequent reefs, shoals, bars, and the neighborhood of rushes and weed patches. These times are usually in the spring or early summer, and in autumn. for in midsummer the hass retire to deep water, except in laree. deep and cool lakes. when this season is often the best, as the water has then become 
of the right temperature to induce the fish to scek shallow feeding grounds.

The habits of the brook trout have been carefully studied by many generations of fly-fishers and naturalists, consequently the trout-fisher lnows that during the summer months he will certainly find his quarry in the shallow streams, slowly but surely ascending toward their spawning grounds. He also knows that the big trout has a local halitation under some root, or rock, or hollow bank, which he holds by right of possession, and defends as bravely as ever knight of old his feudal stronghold. He knows, furthermore, that he would be considered daft to whip the deepest pools of rumning water, or the surface of deep portions of lakes or ponds. So, when the bass-fisher knows the habits of the bass as well, there will be less speculation as to whether or not he will rise to the fly.

The stream should alwars he waded, if practicable, anit fished with the current, for it follows that wherever the angler can wade, the water is about right in depth for flyfishing. He should cast about him in a scmi-circle, he heing at the center and his casts being the radii, like the spokes of a wheel; then, lengthening his cast. he can descrilne the are of a larger circle, and so cover all the water within reach (within forty or fifty feet), giving preference, of course. to the likeliest spots, as the eddies of houlders or half-submerged rocks, near logs, driftwoorl, shoals, bars, and under orerhanging bushes and hollow banks. and over the shallow pools abore and below rapids and riffles.

After casting, the flies should be gently moved on the surface by tremulous morements, to imitate, as nearly as may be, a living fly, and then be allowed to sink sereral inches below the surface and float away like a drowned insect to the extreme length of the line. 
On lakes, where there is no current, the flies should also be permitted to sizk over likely spots at almost every cast. Lakes or deep ponds should be fished from a boat, keeping in the deeper water and casting inshore on the bars, shoals, reefs or ledges, or along the edges of rushes or weed patches. Sometimes rushes or tall weeds grow in pretty deep water, but nevertheless the bass will often be found near or among them, and sometimes near or under floating logs or drift; it is well to try all such places.

It will be found that hass rise to the fly more frecly when the water is stired or rufled by a brisk loreeze, and during the early morning hours and late in the orening; about sunset. or a little after. being the very best time on bright days. On cloudy days there is not much choice, as one hour is no more farorable than another. smme day being always the best.

The old rule of light-colored flies for dark days and toward evening. and dark flies for bright days. is a sale one to follow, the exceptions rather tending to prove the rule, which visully lappen when the fish are well on the feed and will take almost any fly offered; thus it is frequently the ease that dark flies will kill in the dusk of erening as well as the " miller" or " coachman."

It only remains now to say to the reader, east as skillfully as you cam. but always deliberately and carefully. Always lisep) a taut line; strike quickly upon sight or touch, and play and land your fish in your own way, but get him in the creel as quickly as you can with safety to your tackle; kill your fish outright before putting him in your basket: do not fish for count; keep rour temper; and, ahove all things. remember first. last and all the time the most important pule in fly-fishing-liepl out of sight of the fish if you would have him notice your flies. 


\section{Rigging the Cast.}

By a reference to the chapters devoted to the implements of angling, the reader will obtain a full description of those used in fly-fishing. which are the fly-rod, the click reel, the tapered fly-line, the leader, the fly, the fly-book, the creel, the landing-net, and the useful adjuncts for stream fishing, of wading-pants or stockings; and, by ref(rring to the pages on knots, the following directions for rigging the cast will be rendered more intelligible:

A few snelled sproat or O'Shaughnessy hooks should be carried in the fly-book, to use with such natural baits as grasshoppers, beetles or dragon-flies, in case the artificial fly does not prove successful. They are to be used in the same manner as artificial flies.

The beginner being now provided with all the tools, it is in order to put his rod together, attach reel, reel-line, and cast of flies, and proceed to business. In rigging the cast, if the leader is provided with loops at each end, and also loops for drop-flies, proceed as follows: To the small end of the leader attach the stretcher or tail-fly by passing the loop of the leader through the loop of the snell and over the fly, then draw together. Three feet from the tailfly attach the dropper, or bob-fly, in the same manner; that is, put the loop of the snell over the loop of the leader, and push the fly through the latter loop and draw tight; or, if the leader is not furnished with loops for this purpose, slip a linot of the leader (about three feet from the tailfly) apart, and, after making a round knot in the end of the snell of the fly, put it through the opened knot of the leader and draw together; this will hold firm. and the dropper-fly will stand at right angles from the leader.

If. howerer, the gut-lengths of the leader are tied by hard, close knots, instead of the slip-knot or double water- 
lnot, then the snell of the dropper must be attached close to and above a knot of the leader, by a single knot or halfhitch, a round knot having previously been made in the end of the snell, to prevent the half-hitch from working loose; this is probably as good and safe a way as any.

The east is now ready, for I do not advise the use of more than two flies. If, however, the angler wishes to (mploy three, the third fly or second dropper, must be attarhed three feet albove the first dropper, and, in this case, the bealer should be nine feet long. But the beginner will hatre all he call attend to with a six-feet leader and two flies. The leader having been previously straightcned by soaking in water, or rubbing with India-rubber (the former method is to be preferred), and attached to the recl-line, the angler is now armed and equipled as the law directs, and ready for

\section{Casting the Fly.}

Casting the artificial fly is performed by two principal motions, a hackward and a forward one. The former is to throw the flies behind the angler, and tae latter is to project them forward and beyond. That is all there is in it. These are the main principles involved, and the first or backward motion is merely preparatory to the second or forward one, the latter being the most important.

But the style and manner of making these two motions are all-important: for upon the correct, skillful, and, I might sar, scientific performance of them, depends the success of the angler. The main objects of the two motions are. first, to get the line and cast behind the angler in a straight line, without lapping or kinking; and, second, to project the line forward without snapping off the tail-fly, casting it perfectly straight, without confusion, and 
causing the flies to alight before the line, without a splash. and as lightly as the natural insect dropping into the water. This can only be done by the norice with a short line, about the length of his rod, and he should not attempt is Ionger east until he is perfect in this. Then he can lay out his short line perfectly straight before him without a splash, every time, he can then venture further.

To be more explicit: the reel should be underneath, with the handle to the right. The rod is grasped just above the reel with the thumb extended. Keeping the arm close to the body, for the wrist and forearm must do the work, throw the line backward and upward orer the right shoulder, and then straight forward, aiming at a point on the water distant about the length of the line. But little force or muscular effort should be used, as the spring of the rod will be sufficient. This should be repeated a number of times in quick succession, in the meanwhile trying to ascertain exactly when the line is straight behind, before making the forward cast. At no time should the rod extend forward or backward at a greater angle than twenty or twenty-five degrees from the perpendicular, and even a lesser angle would be better. (See figures 1 and 2.) This style of casting is the one practiced by most anglers with any length of line, in actual fishing.

For very long casts, however, and in toumament work, a somewhat different style is used; but it should be borne in mind that nearly every angler has a method of casting peculiarly his own.

The backward and forward movements are each made in about the same length of time, but while the former is a single morement, the latter is a double one; that is, it is divided into two motions, or parts; though these two for- 

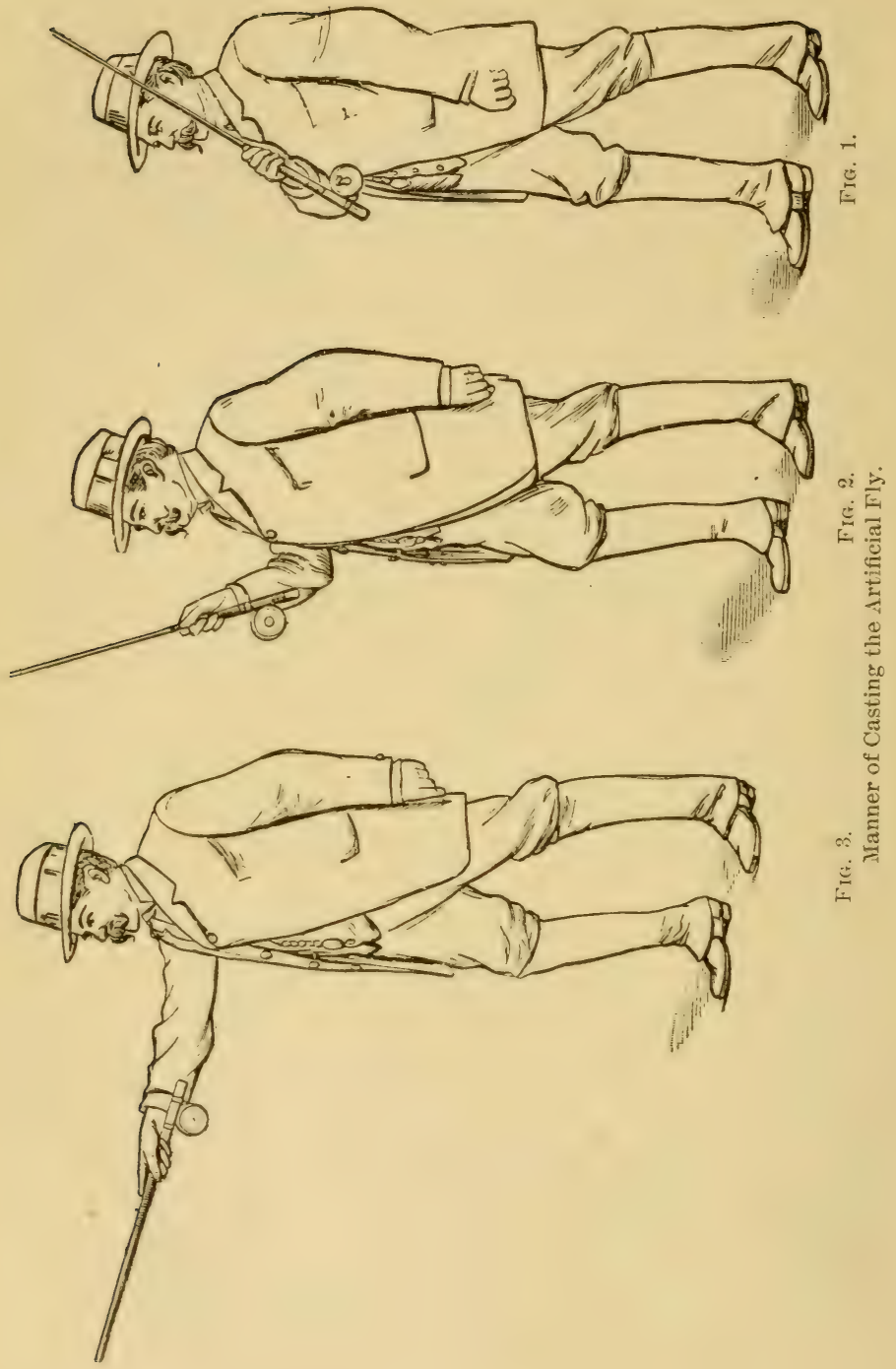
ward motions are male in the same length of time as the backward movement, and without intermission.

I will now try to explain these movements more explicitly, with the aid of the annexed cuts and diagrams.

The prospective fly-fisher having his rod, reel and cast in readiness, stands near the bank of the stream, with a clear space of thirty or.forty fect behind him. Having the line about the length of his rod, to begin with, he takes the hook of the tail-fly between his left thumb and forefinger and stretches the line taut; then, by waving the rod slightly backward over the left shoulder, and at the same time releasing his hold of the tail-fly, the line straightens out behind him, the right ellow meantime being held close to the body, as the backward movement is made with the wrist and forearm entirely. The position of the right hand during this portion of the cast is with said hand grasping the rod just above the reei, and with the reel and palm of the laand toward the angler, the thumb looking toward his right shoulder (see figure 1).

When the line and leader are on a straight line behind him, he brings the rod forward with a gradually increasing rate of speed, until the rod is slightly in advance of him. say at an angle of fiftem legrees off the perpendicular: then, for the first time, the right ellow leaves the body, and, at the simne time, the rod is turned in the hand in the mposite direction (see figure 2 ) ; that is. with the back of the hand toward the angler. so that, at the end of the east, the reel is below the rod, while the back of the hand is upward, anc, without stopping the motion of the rod, the right arm is projected forward to its full extent, and on a line with the shoulder (see figure 3 ). This is the second part or motion of the forward morement, and consists in merely following the direction of the flies with the tip of 
the rod, so as to ease thcir rapid flight, and allow them to descend without confusion, and to settle upon the water noiselessly.

Thus we see that the backward morement is in one time and one motion, and the forward morement in one time and two motions, as the military have it, or according to the following formula of time:

$$
\text { 1. } \mid=2 .(a) !(b) !
$$

No. 1 represents the backward throw, in one motion, in the time of a half note. No. 2 represents the forward cast, in one time and two motions, $a$ and $b$, in the time of two quarter notes. This is not to be uncerstood as fishing by note, but the relative time of making the different motions in asting the fly approaches very nearly that of the formula giren. This is better explained by a reference to the foregoing cuts; where figure 1 represents the barkward throw, and figure 2 represents the first part cir motion (a), and figure 3 the second part or motion ( () , of the forward cast.

Sometimes these morements are made straight backrard and forward over either shoulder, or over the head; hut the hest way is to make the backward movement ever the loft shoulder. and the forward over the right shoulder. the line thus describing an oval or parabola. By this method the flies are not so apt to he whipped off, and it is, withal, more graceful, more en regle.

The following diagram represents the ares described by the tip of the rod and the flies:

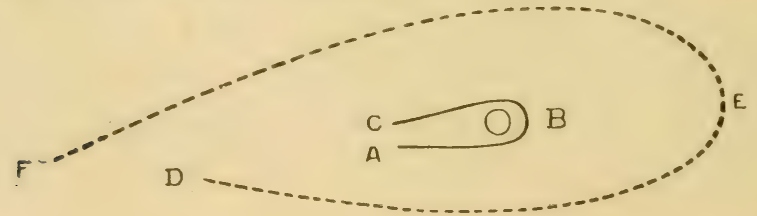


$\mathbf{O}$ is supposed to be the angler, and, as we are looking down upon him from above, it represents his hat. The dark line, $a, b, c$, is the curve described by the tip of the rod in the backward and forward movements of the cast back over the left shoulder, and forward orer the right; while the dotted curred line, $d, e, f$, is the approximate are described by the tail-fly, leaving the water at $d$, and alighting, by a lengthened cast, at $f$. By studying these ciiagrams in connection with the instructions given, the theory and mechanical principles will soon be mastered by the novice.

But various ways of casting come into play at certain times, and under peculiar circumstances; and the rod will be held more or lese to one side or the other, or more rertically, as particular circumstances or emergencies demand. For the novice must remember that there are trees and bushes, and rocks and winds, to contend with in fly-fishing; and, morecrer, as he hecomes proficient, he will choose his own style of casting, for no two anglers cast the fly exactly alike.

However, all methorls of overhead casting are but rariations or modifications of the methods described; and the particular circumstances calling for them will naturally suggest their necesity, use, or adrantages to the angler as he becomes more expert, and gains in knowledge by practical experience. It is hardly necessary, therefore, or even advisable, to allude more particularly to other ways of orerhead casting, as it would, in my opinion, tend more to confuse than to enlighten the beginner.

Then there is the sidewise cast, where the line is not thrown behind the angler at all, but to one side or the other. This style of casting is practiced with a short line, on very narrow waters, or where the hanks of the 
stream are thickly clothed with tall grass or bushes, and where there is not sufficient clear space for throwing the line behind the angler.

In this mode of casting, the angler throws the line landward, over the grass or bushes, to the right or left, as the case may be ; and, when the line has unfolded in a straight line, to cast toward the water by an opposite sidewise cast. In all other respects, the management of the cast must approach, as nearly as possible. the regular orerhead cast.

Another methorl of casting that occasionally comes into play is "switehing." This mode is rery useful where high banks. frees or bushes render the orerhead and sidewise cast impracticalble, though it admits of but a very short line being $11 \mathrm{er}$, shorter than in the sidewise cast.

Switching is performed hy raising the arm and rod to their fullest extrint, vertically, thus drawing the flies close to, and in front of. the ancler; then, by a quick, smart, motion of the rot. Aownwart. the flies are projected forward. or laterally ats the angler may wisl. The forward motion is much like striking with a whip or switch, and is more easily imagined than deseribed.

But let ns go hack to our tyro. who has now become proficient with the short line. for it is time to lengthen his east. which is tone in this way: IIe pulls off from the real with the left hamd three or four feet of line, and lifting his rorl, slowly at first, by a gradually increasing motion lifts the leater and flies and throws them upward and backward over the left shoulder. as before described. The resistance of the leater and flies. before they leave the water. takes the extra length of line from the rod, and it is unfolder behind the angler in a straight line, when he casts it forward over the right shoulder.

In this way the line is lengthened at every cast, if neces- 
sary, until the maximum or desired distance is reached. But the angler should never let his flies touch the ground behind him; but must so time the movement as to propel the line forward at exactly the right moment to prevent this.

Another caution: The angler should never attempt to cast his flies by main strength, for this will accomplish nothing but confusion; it takes but little force to retrieve or cast the flies with a well-made, springy and pliant rod. The rod, moreover, should never be carried back over the shoulder to a distance exceeding an angle of fifteen degrees off the perpendicular, for the backward throw is really accomplished by the time the rod is in a vertical position, and this might be said, also, to a certain extent, in regard to the forward movement or cast proper; for by the time the rod is fifteen degrees off the perpendicular in the other direction (in front), the main part of the cast is made, and the second part of the forward morement is only to follow the flies with the point of the rod, to ease their flight, as before mentioned; this latter part of the forward cast can no more aid or extend the flight of the flies than pushing on the reins can increase the speed of your horse.

I have now, in the fewest words possible, and in the simplest manner, endeavored to explain the "mystery" of casting the fly, and I trust the beginner will be able to understand it. It is almost impossible to describe the art clearly and satisfactorily by mere words. One hour with a good fly-fisher will teach the norice more than a hundred written pages. I have purposely omitted many little details of nicety and precision, which would only tend to magnify the supposed difficulties of casting, and create doubt, confusion, and a lack of confidence in the mind of the beginner in the noble art of fly-fishing. 


\section{General Instructions.}

It is useless to cast for black bass from high elevations near the water, as a bold bank, a projecting rock, a dam, ctc., under ordinary circumstances; for the angler must remember that the most commanding situation for seeing the fish also furnishes the best facilities for being seen in return, and vice versa. In fishing from a boat, it must be kept in deep water, while long casts are made in-shore, toward the feeding grounds. We should nerer fish with the sun at our back, or in such a position as to throw the shadow of our rod or person upon the water.

From. what has been said in the chapter on the "conditions governing the hiting of fish," it will be apparent that it is absolutely necessary that there be a breeze sufficient to ruflle the surface of the water. It is folly for the angler to cast his flies upon a smonth surface, if the water is clear enough for fishing. A gale is better than no wind at all, and it does not matter from what direction the wind blows, if the condition and temperature of water are right. A good breeze is the angler's best ally, for by rippling the water it hrealis the line of sight, to a great extent, between him and the fish.

The angler should enrleaver to cast his flies as lightly as possible, causing them to seitle without a eplash. After casting. the flies should be allowed to sink several inches near likely-looking spots. If the current is swift, allow the flies to fioat naturally with it, at times. before being withdrawn for a new east. Two or three times are enough to cast over any one spot. when a rise is not induced.

When bass are not biting eagerly, whipping the stream may he practiced: that is. the casts are to be often and rapidly repeated, allowing the flies to settle but a moment before finally allowing them to sink. In casting and ma- 
nipulating the flies, the line must be ever taut; for often a bass will thus hook himself, which he never does with a slack line.

\section{Striking and Playing.}

The angler should strilie by sight, or by touch; that is, he should strike the moment he sees the rise; for the bass has either got the fly in his mouth, has missed it, or has already ejected it, "when the rise is seen; it very seldom happens that the rise is seen before the fly is reached by the fish. The angler must also strike at the moment he feels the slightest touch or tug from the fish, for often the bass takes the fly without any break at the surface, especially if the flies are beneath it.

Striking is simply a twist of the wrist, or half-turn of the rod, either upward or downward (upward with stiffish rods, and downward with very willowy ones), which is sufficient to set the hook if the rod and line maintain a proper state of tension; but when the careless angler has a slack line, and, consequently, a lifeless rod, he must necessarily strike by a long upward or side sweep of the rod, called "yanking," and should he succeed in hooking the fish, the chances are that it will shake the hook out again before the slack can be reeled up.

The tip of the rod must always be held upward, so that the rod constantly maintains a curve with the line; and never, under any cireumstances, must the rod point in the direction of the flies after they reach the water, for this allows the direct strain of the fish to come upon the line or leader. When a hass is hooked, he must he killed on the rod; the rod must stand the brunt of the contest; the more pliable and springy the rod, the less likelihood of its breaking, for a stiff rod is more easily fractured than a 
flexible one. Give more line only when he takes it; make him fight for every inch, and take it back when you can; hold him by the spring of the rod, and do not hesitate to turn the butt toward him to keep him away from weeds, rocks, snags, or other dangerous places; this will bring him up with a round turn, and is called " giving the butt."

Don't be in a hurry to land him; the longer he resists, the better for your sport; take your time and only land him when he is completely exhausted; for if he is wel! hooked, and the proper tension of rod and line maintained, he can not get away; on the other hand, if he is tenderly hooked, the more gingerly he is handled the better. Therefore, never be in a hurry, and never attempt to force matters; always keep a bent rod and taut line; if the bass breaks water on a short line, the best plan is to lower the tip, so as to slack the line, but immediately raise the rod and tighten the line when he strikes the water again, for if he falls on a taut line he is most sure to escape; this is one of his most wily tricks. With a long line it does not matter so much.

\section{Remarks, Hints, and Advice.}

It has been doubted by some that the black bass will rise to the $\mathrm{fly}$, or at best that they are uncertain in their modes and times of doing so, as compared with the brook trout. These doulsts are mostly raised by those who angle for the black bass in precisely the same way as for the brook trout, upon the supposition that the two fish are identical in habits and instincts. But while their habits of feeding are very similar - both feeding on the bottom, in midwater, or on the surface, on crustacea, larvæ, minnows, insects, etc.- they differ greatly in other habitual features and idiosyncrasies. 
The black bass will rise to the fly as readily, under any and all conditions, as the brook trout, when fished for understandingly, and under proper precautions. There are times, seemingly favorable, when neither bass nor trout will rise to the fly.

One reason why the bass is thought to be uncertain in rising to the fly is this: While he is fully as wary as the trout he is not so timid. A trout darts incontinently away at the first glimpse of the angler, and is seen no more; but the bass will retire but a short distance, and as often will stand his ground, and on balanced fins will watch the angler vainly casting his "brown hackle" or "coachman" over him, perhaps laughing in his sleeve (shoulder girdle) at his discomfiture. The truth of the matter is, the bass is not uncertain, hut he is too knowing to be deceired by his flies, so long as the angler is in sight.

Fish are more suspicious regarding oljects on the surface of the water than of those beneath. I have often demonstrated this, causing them to skurry away, by holding a long stick immediately over them, above the surface; while I could introduce the same stick underneath the water and even prod a fish with it, without alarming it much. This is why more caution is necessary in fly-fishing than in bait-fishing; the bait in one instance being on the surface, and in the other, beneath. If a black bass, in rushing to the surface for the fly sees the angler, he at once stops in his course, and thenceforth the daintiest flies, though never so deftly thrown, will be cast in rain while the angler remains in view.

In the London "Field" once appeared an article. written by the former alle exlitor of that ralualle paper. Francis Francis, Esq.. on the frightening of brook trout by the flashing and reflections of a varnished fly-rod, when wildly 
waved by the angler in casting, and which, at first sight, would seem to be plausible enough; but upon mature consideration, and with all due deference to so eminent an authority as Mr. Francis, I am convinced that there is not much in it, and that instead of proving the matter he seemed to be rather begging the question.

The theory of angling. like the theory of medicine, is rather an uncertain sulject, and opposite positions can be taken and seemingly maintained upon almost any question of either science, until the erucial test of practical experience proves their truth or falsity. The fact is, that fish are not frightened by flashes of light or the reflections of bright oljects, but, on the contrary, are attracted hy them; any one who has erer fished hy torchlight. or trolled with a bright metal spoon. can testify to this. and there is a method of fishing practiced by the C'hinese, by means of a hoard painted white and attached to a boat at such an angle as to reflect the light of the moon wpon the water, when the fish, attracted by this, jump upon the hoard as the boat is moved along.

That fish are not much disturbed, if at all, hy the flashing of a polished fly-rod. per se. (am he easily proven by any one who, being securely hid behind a clump of hushes, can wave his rod as "wildly" as necessary without alarming them to an extent to frighten them away or prevent their biting; indeed, the unnatural shaking or disturbance of a bush near the brink, hy the careless angler, will alarm the denizens of the stream more than the most highly-varnished and brightly-mounted rod ever made, when waved over the stream by an angler who keeps himself hid from view; and herein lies, to my mind, the key to this whole matter.

It is the angler who scares the trout, and not his rod; 
and this probably applies with more force to the comparatively narrow and open streams of Great Britain than to the more extensive waters of our own country; this view seems more probable in connection with the fact that Mr. Francis adrises casting sidewars instead of orerhead, which method could only be practiced successfully on narrow streams, for sideway casts are necessarily short ones, anil would not answer at all for most of our waters. There are situations. howerer, when the sideway cast can be usent advantageously, and is used oceasionally ly all good flyfishers.

The main rules to he observed in fly-fishing I conceive to be these: on narrow streams to licep entirely out of sight, and on open waters to make long easts; in either case, the fish, not secing the angler, will not be alarmed at the flashing of the rod; the finer the water the greater the caution that must be used on the one hand, and the longer must be the cast on the other.

Mr. Francis does not offer any remedy for the varnished rod, but merely suggests that it might answer to paint it sky-blue, or a dull, smoky tint. without polish ; but this. I know, will not do. I have seen rods that had the rarnish scraped off and were painted a delieate pea-green, to harmonize with the foliage of trout streams. and I have seen the bark left on alder, elm. and tamarack poles when used in bait-fishing. but they were not more successful than the varnished rod.

Split-bambon and other jointed rods must of necessity be varnished to preserve their clasticity and heauty. Think of a delicate split-bambon tip enated with sky-blue paint! The very thought is heresy. and an offense against the eternal fitness of things that would make eren the spots on a brook trout blush more deeply crimson. American 
split-bamboo rods are the best in the world, and the numerous foreign orders received by the manufacturers fully attest this fact, and show, moreover, that they are duly appreciated abroad, as well as at home, highly varnished and flashing though they be.

There is one feature of this subject that is peculiarly gratifying to me, and I heartily thank Mr. Francis for the article in question. It concedes the fact that fish. having eyes, can see, and are not the near-sighted dupes that most writers would have us believe; this concession could not be put in a stronger light than by the assertion that they are frightened at the flashing of a varnished rod, and that a rod, therefore, should be rendered as nearly invisible as possible by painting it a sky-lnlue or cloud color. But if this were done, what a quantity of brash wood and poor workmanship, and what a multitude of sins of omission and commission would this sky-blue mantle, like charity, cover!

When fish are frightened at a fishing-rod at all, it is when its shadow is suddenly cast upon the water - which all prudent anglers are very careful to avoid doing, especially on small streams - and. viewed in this light, a skyblue rod has not even a fancied advantage over the most highly-polished one.

The most important rule, then, to be observed. first, last, and all the time in fly-fishing, is: ieep out of sight of the fish; this is the first and great injunction; "and the second is like unto it:" Keep as quiet and motionless as possible. "()n these two" laws depends all your suceess in fly-fishing. Let your necessary movements be deliberate and methodical, avoiding all quick, sudden, or energetic motions. Fish see and hear much better than we give them credit for. To keep out of the fish's sight we must 
be screened by such natural objects as bushes, trees, rocks, etc., or by keeping well back from the brink and making long casts. In wading, it is also necessary to make long casts. The latter is the best plan of fishing a stream, as the angler, being so near the water, is not so apt to be seen.

It is best, always, to fish down stream, even with the wind against one, for fish always lie with head up stream, and will be more apt to see your flies. The current will, moreover, take your flies down stream, and so keep your line taut. It is also easier to wade down, than up stream. Many other reasons might be given, but these will be sufficient. Cast just below ripples and rapids, over eddies and pools, along the edges of weed patches, under projecting banks and shelving rocks, near submerged trees or driftwood, off gravelly shoals, isolated rocks and long points or spurs of land; it is useless to fish long, deep, still reaches of water.

The most farorable time for fly-fishing for black bass is during the last hours of the day, from sundown until dark, and also on bright moonlight evenings. On streams, an hour or two following sunrise, in warm weather, is quite favorable. On dark, cloudy, and cold days the middle hours are best. Bright sunny days, especially in hot weather, are not farorable to fly-fishing, except in quite cool, shady, and breezy situations. In short, the lest conditions are a mellow or dusky light, a good breeze, and translucent water; while the most unfavorable are a bright sun, a still atmosphere, and a smooth and glassy surface, with the water either very fine or very turbid.

And now, in concluding this portion of my subject, let me say a parting word to the beginner: Cast a straight line; keep it taut; strike upon sight, or touch; kill your fish on the rod; take your time. It is better to cast a short line well, than a long one bunglingly. Should you cast 
your fly into a branch of a tree orerhead, or into a bush behind you, or miss your fish in striking, or lose him when hooked, or crack ofit your tail-fly, or slip into a hole up to your armpits - keep your temper; above all things don't swear, "lest you be heard." as Izaak Walton says, "and catch no fish." Remember. yours is the gentle art, and a fly-fisher should be a gentleman.

\section{A Reminiscence.}

Toward the close of a day in the mild September, I wa: leisurely riding my tired mare across the forel of a narrow rocky river that wound around the foot of a thickly-wooded cliff, with here and there a pool in the sharlow or a riplple in the sum, while stretching a way a mile or two accross the fertile bottom lands were fields of waving corn, fragrant clover, blue-grass and broad-leaved tobacco.

Tp the stream a hundred yards away, stood. leaning over the water, an old stone mill, whose lichen-corered walls and moss-grown roof proclaimed its hoary age. Its old wheel went rumbling on its merry round, mingling its regular, rhythmic plashing with the monotone of the tumbling, rushing waters of the dam.

Down the stream another hundred yards, an old-time, covered bridge. decrepid and gray, spanned the little river, casting cool and dark shadows beneath and below.

The sun was sinking low heyond the fields, flinging bars of yellow flame through the slender strips of fleecy clouds that stretched across the western portal of the steel-blue sky, lighting up the crimson of the newly-dyed sumach on the cliff, flashing on the foaming waters of the falls, and festooning with golden streamers and silver ribbons the long, dank, green arms of the old water-wheel.

Beneath the bridge a group of ruminating, sleek-coated 
cows stood whisking their tails in calm contentment, as the grateful stream laved their cloven feet and their breath exhaled the odors of sweet cream, white clover and golden butter.

As my mare drank deeply from the refreshing stream, I gazed upon the lovely scene, and thought that nowhere else in all the world but in this broad land of ours could such a view be found.

The sublime glories of the Alps; the soft Italian skies; the splendors of the Tropics; the olive-crorrned hills of Andalusia; the vine-clad slopes of the Riviera - all alike paled before this calm and peaceful, soul-filling, heartsatisfying, hometike scene.

But what was that? - a bar of silvery sheen flashed for a moment in the sun and dropped back into the eddy behind yon huge gray boulder under the cliff! I pretend to be surprised, but - pshaw! how idle it is to attempt to deceive oneself. All the time that I was hollowly and falsely descanting upon the matchless beauty of the stream and its surroundings. I, like an artful, doulble-tongued hypocrite, was watching for the very thing that occurred - the leap of a bass!

Silently I rode my mare to the shade of the cliff, tied the reins to the convenient limb of a low-branching elm, unstrapped my umbrella from the saddle, and from its folds drew forth a fly-rod that had been artfully and surreptitiously concealed there - another evidence of the insincerity of man.

From a corner of my pill-bags I brazenly took out a buckskin bag. in which was a small click reel with its line of enameled silk. From a pocket of my professional coat I brought to the light of day what. ostensibly, purported to he a prescription book, but in reality was a book of flies! How guilty I felt! What an arrant humbug I was! But 
there was no time for moralizing - I just heard the splash of another bass! I soon had rod and reel, line and leader together, and a "polka" and a "professor" were soon dancing over the water together!

I had stepped from boulder to boulder, in the shadow of the cliff, until I had reached a vantage point at the foot and edge of the riffle, with the sun in my face and broken water all around me. I knew of half a dozen deep holes and sheltered eddies within the length of my cast, from which I would be completely hidden by two jagged rocks that rose in front of me, half as high as my head.

Then like a guilty thing I began casting in ever-widening circles - all the time pretending to wateh the play of the sunshine on the water, or the blackbird that was drinking at the verge of the stream.

Then I saw a swirl behind the gray boulder - but pretended to be listening to a squirrel barking at me from the projecting limb of a hickory, whose glossy, green leaves were just touched with the faintest suspicion of old gold.

Then I made another cast as straight as the maple boll behind me. The flies dropped just over and beyond the smooth. gray houlder, and as they were drawn into its eddy the "polka" disappeared, and something seemed to lift the water just there for an instant, and then - what a lively staccato to that kingfisher's rattle!

But, bless my soul! it is my reel that is giving so merry a hum! I must stop that. Then, as I follow the erratic flight of a dragon-fly across the stream, I can't help observing my strained line cutting like mad through the water, and as I look up at a crow flying overhead I see that my rod is bent, and strained and twisted, and altogether there seems to be something unusual going on in the water, and as I look - out into the sunshine with bristling fins and red, extended jaws there leaps a bass! 
Then I am kept busy leading my line away from jagged rocks in front, and can only do so by holding my rod at arm's length above my head. But now I have led the captive into the deep pool below me, and near the cliff. Then I have leisure to look up at my squirrel, who, with a hickory nut in his paws, is raining down the pieces of its hull in a green shower at the river's side, and - there leaps the bass again! - and again! Then again the singing of the reel as he dives to the depths of the pool.

Ah! listen to the allegro of the mocking-bird atop of yonder beech, as he begins his sunset sonala - the click of my reel a castinet accompaniment - and now, while slowị reeling in the line, the andante of the glorious songster is poured out on the quivering air - and then the trio - the hird and bass and I - and last of all the finale, as I drop the butt of the rod and the reel into my coat pocket. and hug my vertical rod, while lifting out the spent warrior in green and silver sheen, and quickly dispatehing him, tos; lim among the ferns at the foot of the hickory, to the great displeasure of my squirrel, who scolds and scampers away with the nut in his cheek.

Then, filling my pipe, the blue smoke ascends in curling wreaths and is borne away up the face of the cliff on the soft erening air, while the tinkle of a cow-hell and the hoot of an owl comes from the direction of the old bridge.

But the sun is on the edge of the horizon, the fall is bathed in flame, the mill-wheel is hung with rubies, the belated crows caw loudly, and the "professor" and the "polka" are dancing on saffron and crimson foam to the strident strains of the cicada's fiddle. What, another rise? Another hass. perhaps! No, it must have been a swallow dipping its wing.

The gentle swish of the supple rod is music sweet as the "professor" and the "polki" follow each other, now in 
aerial flight, now along the shining water. Egad! there's no mistaking that tug! The reel and the cicada now have it! The line hisses through the water! Look out for the sharp rock! Sce that blundering bat! Nh, what a leap! - how he dashed the golden, crimson rain! Again the duet - the shrill cicada and the buzzing reel! IIe breaks again. again falls back! The rod is bending. surging through the air - and now the frogs pipe up - the sun is down - and, bless me! here's another bass!

I step ashore, ant string them on a willow wand. The mill-wheel has stopred; the water tumbles over the fall with a lonesome sound. The whipponswill is calling from the clift. The squirrel is in his nest. The mocking-bird has found his mate. The ents are lowing at the farmer's gate. My patient nag is neighing for her master. "All right, Jenny!"

I do wot fere so guilty in the eloaming: and as the first silent star appears. I stop at the litte tumbledewn gate

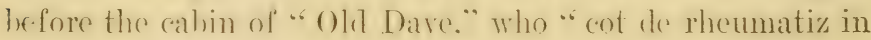
de fresh' las' spring."

"Hello! Aunt Judy. How's Uncle Dare?"

"Howdy, Doctah! Lor" bress you, honey, de ole man's mitey po'ley — jist kin hobble roun', an' dat's all. He

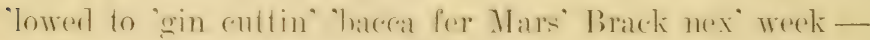
but "less he men's miter fase' he wonte ent more"n a 'bacea wum kin chaw! Don't tink he's long fer ole Kaintuck, no how!"

"Come here, Aunt Judy: here's two nice lass for you they"ll go nearly two pounds apiece. I gentleman fishing down at the river gave them to me as I came along. They"ll make a fine hreakfast for you and Encle Dave in the morning. Good night!"

And Jemny and I jogred along toward home, under the bright stars, at peace with all the world. 


\section{CHAPTER XXII.}

\section{CASTING THE MINNOW.}

"And as to the rest that concerns this sort of angling, I shall wholly refer you to Mr. Walton's direction, who is undoubtedly the best angler with a minnow in England."-Charles Cottor.

Next to fly-fishing, casting the minnow is the most artistic mode of angling for the black bass. To obtain all of the pleasure and sport embodied in this style of fishing, none but the best and most approved tackle should be employed, which should approach, in its general features of elegance and lightness, the implements used in fly-fishing.

A faithful study of the conformation, habits, and idiosyncrasies of game-fish should be the first consideration of the true angler, though the average angler usually contents himself with a superficial knowledge of the ways and means of capturing and killing the finny tribe, a big catch being the height of his piscatorial ambition. While good tackle is essential to success, a thorough knowledge of the habits of the fish is a sine qua non, without which no one can become an expert and successful angler.

A propos of this might be mentioned the old and hackneyed story of the rustic youth with alder pole, twine string, and worm bait, and the soi-disant angler with split-bamboo and well-filled fly-book, who indulged in a day's fishing on the same stream, with the result of a "big string" for the boy, and one poor fingerling for the disgusted sportsman. The boy understood the "true inwardness" of the trout, in which matter the discomfited citizen was lament- 
ably ignorant, and relied entirely upon his splendid rig for success.

Where black bass are plentiful, as in the quiet ponds and lakes of Indiana, Michigan, Wisconsin, and Minnesota, at the Thousand Islands of the St. Lawrence, and in the extreme south, the merest tyro, who can throw his bait twenty feet from the boat, can, when the bass are in a biting mood, show a big catch, though he may necessarily have failed to land two out of every three fish hooked. But on small rivers, where the angler casts to the right and left and across the stream from the banks, and while wading the shallows and bars, and the bass are shy, educated, and fully up in a knowledge of the stream in its windings, eddies, pools, and rapids, the highest skill and a thorough knowledge of the habits of the fish are indispensable to a full creel; and this, at the same time, constitutes the pleasure and perfection of black bass angling.

But bear in mind, that sticking the butt of a long rod in the bank, and then, while reclining under the shade of some umbrageous tree. enjoying a pipe or the latest novel while waiting an hour for a bite, is not angling, but simply loafing, and attempting to obtain bass under false pretenses.

Casting the minnow is quite an art, as much so as casting the fly; indeed, I think there are more good fly casters than good casters of the live mimnow. Mediocrity in both methods of angling is readily acquired, but great excellence and perfect skill are rarely attained in either. The two methods are essentially and practically different, and require implements and tools commensurate with this difference.

While the fly-rod is willowy and long, the minnow-rod is short and comparatively stiff; the fly-line is rather heavy 
and of large caliber as compared with the minnow-line, which should be as fine and light as possible, consistent with strength. The artificial fly is cast by the weight of the fly-line and suppleness of the rod, while the weight of the bait, and swivel or sinker, give the necessary momentum for casting the minnow. The fly is usually cast overhead, directly in front of the angler, while the minnow can only be cast, for any great distance, to one side or the other, or obliquely, by underhand casting.

\section{MinNow TACKLE.}

The Minnow Casting Rod.-The rod for casting the live minnow should be shorter and stiffer than the fly-rod, but of about the same relative weight; for it, like the flyrod, is a single-handed rod. It should be from eight to eight and one-half feet long. Eight and a quarter feet is the standard length that I have advocated for many years, though the manufacturers, in order to suit all tastes, now make this style of rod from seven and one-half to eight and one-half feet long. It should weigh from six and a half to eight ounces, according to the material and excellence of its construction. It should be well balanced, with a stiffish back, to insure good casting, but pliable enough to respond to the slightest movement of the fish. Most of the bend and play should be in the upper two-thirds of the rod, which bend should be a true arch, and not a horse-shoe curve, as is often seen in a poorly-constructed and weakbacked rod. The best material for a serviceable rod of this character is an ash butt and lancewood second and third pieces, the latter being usually known as the tip. The reel-seat should be from six to eight inches from the extreme butt, and no more, for this rod must be used with the hand alone, and should not extend under the elbow for sup- 
port, like the old-fashioned long and heavy rods. It should have light standing guides instead of rings.

The capabilities of the minnow-casting rod are equal to most of the possibilities of bait-fishing, as it has been my good fortune to prove on many occasions. To the unversed in the real art of angling it is simply wonderful to see what an amount of strain the little rod will successfully endure, and to witness the comparative ease with which exceptionally large fish are killed by one who knows the latent virtues of the Henshall rod.

Long ago, before every island boasted a summer cottage and a steam-launch, and when the black bass, or mascalonge, were to be found in almost every rock-bound, lilyfringed cove, the Thousand Islands of the St. Lawrence possessed attractions for the lover of the beautiful and the angler that is hard to realize at the present day.

Such a time I remember well; and one day of that halcyon period is marked on the calendar of memory by a pure white stone that sometimes, when the fit of retrospection is on, shines out vividly in the "hollow down by the flare" in the bright coal fire in the grate, or in the log fire in camp.

It was below Grenadier Island, in the shallower portion of the river, along the edges of the rushes, deer-tongue and water-lilies, that a dear friend (poor Dick! he is dead now) and I were casting the minnow for black bass. On that lovely July morning I killed, on an ash and lancewood, eight-ounce rod, a mascalonge weighing thirty-two pounds, in twenty minutes.

But, it is under the palms and live-oaks of southern Florida that the angler is more likely to encounter finny giants that will test the strength and endurance of his tackle, and exercise to the full his stock of piscatorial skill and finesse. 
A few days after Christmas, in the winter of 1881, my wife and I were fishing in San Sebastian River a half mile above its confluence with Indian River. We had been up one of the branches of the river fishing for black bass, and I was using an eight-ounce, ash and lancewood Henshall rod, and ordinary black bass tackle.

On this occasion, and with this rod and tackle, I killed a redfish, or channel bass, in twenty minutes, that weighed fully thirty-five pounds, though, as I did not weigh it, I called it thirty. It was a heavier and gamer fish than the mascalonge alluded to above; and, as I have weighed a good many redfish running from twenty to forty pounds, I can certainly guess within five pounds of the weight of one within these limits.

I was casting the minnow for black bass, on another occasion, up the St. Lucie River, in southern Florida, and with the same rod and tackle just mentioned I hooked, killed and landed a tarpon of thirty-three pounds, in fifteen minutes.

I have, with the same, or similar rods and tackle, killed many pike, mascalonge, tarpon, groupers, salt-water trout, etc., between ten and twenty pounds, but merely mention the above instances to prove the power of the minnowcasting black bass rod of eight ounces in weight and eight and a quarter feet in length, and this must be my excuse for alluding to them here.

The introduction of this rod has no doubt done more than any thing else to popularize this style of fishing, and we may now consider minnow-casting as not only firmly established, but as an original and American method of angling that is peculiarly adapted to bait-fishing in our varied. and extensive waters.

As an instance of its popularity I might add that, dur- 
ing the past twenty years, I have seen it employed in the waters tributary to the Red River of the North, in the Northern Peninsula of Michigan and Wisconsin, in nearly all the Provinces of Canada, and in Florida, and in many waters between. I have also seen it in numerous instances made to apply as well to estuary or coast fishing.

While minnow-casting for black bass is the most popular method in vogue in the middle west, it is very gratifying to me to see the favor with which it has been received in the eastern states, and the remarkable progress that has been made in that best of all modes of bait-fishing; for it must be remembered that black bass fishing north of the Potomac and east of the Alleghany MIountains is of comparatively recent origin, as it has not been many years since the black bass was introduced into eastern waters.

As a member of the Committee of Arrangements of the tournaments of the National Rod and Reel Association, I succeeded in having a special contest for "casting the minnow for black bass" admitted in the program of events at the tournament of 1884, when the longest cast, with a half-ounce sinker, was made by Professor Alfred M. Mayer, the same being 97 feet.

At the subsequent tournaments the casting continually improved, until at the one, held in May, 1888, there were three gentlemen who cast upward of fifty yards; and out of five casts made by Mr. A. F. Dresel, the successful competitor, three of them went beyond fifty yards, and one reached the extraordinary distance of 168 feet, 4 inches. The weight of sinker cast was one-half ounce. The rods used were about eight and a quarter feet long, and about nine ounces in weight.

Mr. F. B. Davidson, of Chicago, however, holds the record for the longest casts with a half-ounce sinker. He 
was awarded medals as follows: At the contest during the Chicago World's Fair, on September 2tth, 1893, longest cast 152 feet. I was one of the judges of this erent. At a contest of the Chicago Fly-Casting Club, August 5th, 1894, he cast 179 feet. At a subsequent contest, about. 1896, he made three casts of 198 feet; his average of five casts being 173 feet.

The Reel.-The multiplying reel is the only one adapted to casting the minnow, and it should be the very best one made. It should run as easily and smoothly as possible, and multiply from two to four times. The improved black bass reels referred to in the chapter on reels are all excellent implements.

The Reel-Linc.-First and formost among the suitable lines is the smallest size, $\mathrm{H}$, or No. 6 , plaited raw silk line. It should be braided hard and close, and tinted or parti-colored. Where the bass are exceptionally large, size G, or No. 5), may be used, though the smaller or finer the line the better, for a gut leader can not be used in casting the minnow, and longer casts can be made with the finest lines. The proper length for a reel-line is fifty yards.

The boiled silk braided line is next best, but it is not so closely plaited, usually, as the raw silk line, and consequently absorbs more water, which is detrimental to casting. When it is as hard braided as the raw silk line it is about as good.

Next in order is the braided linen line; the smallest size, G, or No. 5 , is the only size to be used, and that is rather large.

The last, though with some not the least, in point of merit, is the relaid Japanese sea-grass (so-called) line, which is made of raw silk, and in some respects is a better 
line than any mentioned, being of smaller caliber, very hard twisted, and absorbing less water when new. But being a twisted line, it is apt to kink where much casting is practiced.

Twisted silk, linen, or cotton lines should never be used in this mode of angling, as their kinking propensities will ruffle the temper of the mildest-mannered angler.

Hooks. - The hook beyond comparison. for black bass fishing, is the Sproat. It is a true. central-draught hook, and tempered just right. It has a short barl, with cutting edges, which will go right through any part of a fish's mouth. The next best, in the order named, are the O'Shaughnessy and round bend Carlisle (Aberdeen). These hooks are all numbered about alike, and the most suitable sizes are Nos. 1 and 2. IIooks should be tied on gut-snells, single or double, good single gut being best. Where pickerel abound, the gimp-snell may be used.

sucicels. - I hras box-swivel of the smailest size should always he ueed. and often it will he heary enough without an additional sinker.

sinkers.- Ringed or swivel sinkers. or what is still better, the patent adjustalble sinkers of various kinds, are the best to use, when they are found necessary.

Floats.-The float should never he userl in casting the minnow if it ean possibly be dispensed with. It is always in the way, and long easts can not be made when it is employed. To orerenme this difficulty and oljection, sereral patent floats have been devised, which are mentioned in chapter xrir. In still fishing, the float may be used and with advantage, especially where helgramites or crawfish are used as bait. 


\section{Rigging the Cast.}

In rigging the cast with the minnow, the reel must be placed underneath the rod, on a line with the guides. Many anglers use the reel on top, but this is essentially wrong. The weight of the reel naturally takes it under the rod, where it balances better and enables the rod to be held more steadily; the strain of the line also falls upon the guides, which insures a more perfect working of the rod. Both click and multiplying reels should always be used underneath; they are intended to be so used, and it will be found far the best way when one becomes accustomed to this plan.

The reel then being underneath, the line is rove through the guides and a box-swivel tied on the end; to the other ring of the swivel is looped the snell of the hook. The hook is then passed through the lips of a minnow, from two to four inches long. If the minnow is carefully hooked, it will live a comparatively long time. If a sinker be required in addition to the swivel, it should be placed a foot above it.

\section{Making the Cast.}

Now reel up the line until the sinker, or swivel, as the case may be, is a few inches from the tip of the rod, and w: are ready to make a cast, which I will now endeavor to explain with the aid of the annexed diagram and cuts:

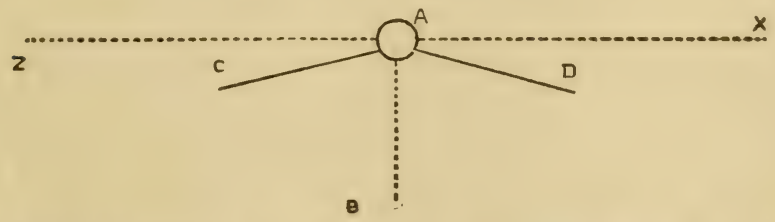

In the diagram, A represents the angler; we are supposed to be looking down upon him from above, so that 
only his hat and rod are visible. He is facing B. The angler now wishes to make a cast to the left, $\mathrm{X}$ being the objective point to which he desires to cast the minnow, some twenty yards distant. He grasps the rod immediately below the reel with the right hand, with the thumb resting lightly but firmly upon the spool, to control the rendering of the line; the right arm is extended downward, slightly bent, with the elbow near the body, and with the extreme butt of the rod nearly touching the right hip; the thumb and reel are upward, inclining slightly toward the left; the tip of the rod, or rather the minnow, just clears the ground or surface of the water (the angler is supposed to be warling, standing in a boat, or on the lank); the position of the rod is now in the direction of the line $\mathrm{A} \mathrm{C}$, inclining toward the ground or water, making an angle of about $30 \mathrm{deg}$. with the line of the shoulder:, $\mathrm{X} /$ (the inclination of the rod is shown fully in figure 4); this is the situation at the beginning of the cast.

Now for the cast: The angler turns his face toward $\mathrm{X}$, the objective point, without turning his body; he now inclines his body in the direction of $\mathrm{C}$, advaneing the right foot and bending the right knee slightly, and makes a sweeping cast from the right to the left, and from below upward, across the body diagonally, until the rod-hand is at the height of the left shoulder, and the arm and rod extended in the direction of $\mathrm{A} \mathrm{D}$, with the tip of the rod inclining upward, as shown in figure 5.

The movement of the right hand is almost in a straight line from a point near the right hip to a point near the left shoulder; the motion in casting is steady, increasing in swiftness toward the end of the cast, and ending with the "pitching" of the bait - instead of a violent jerk - 


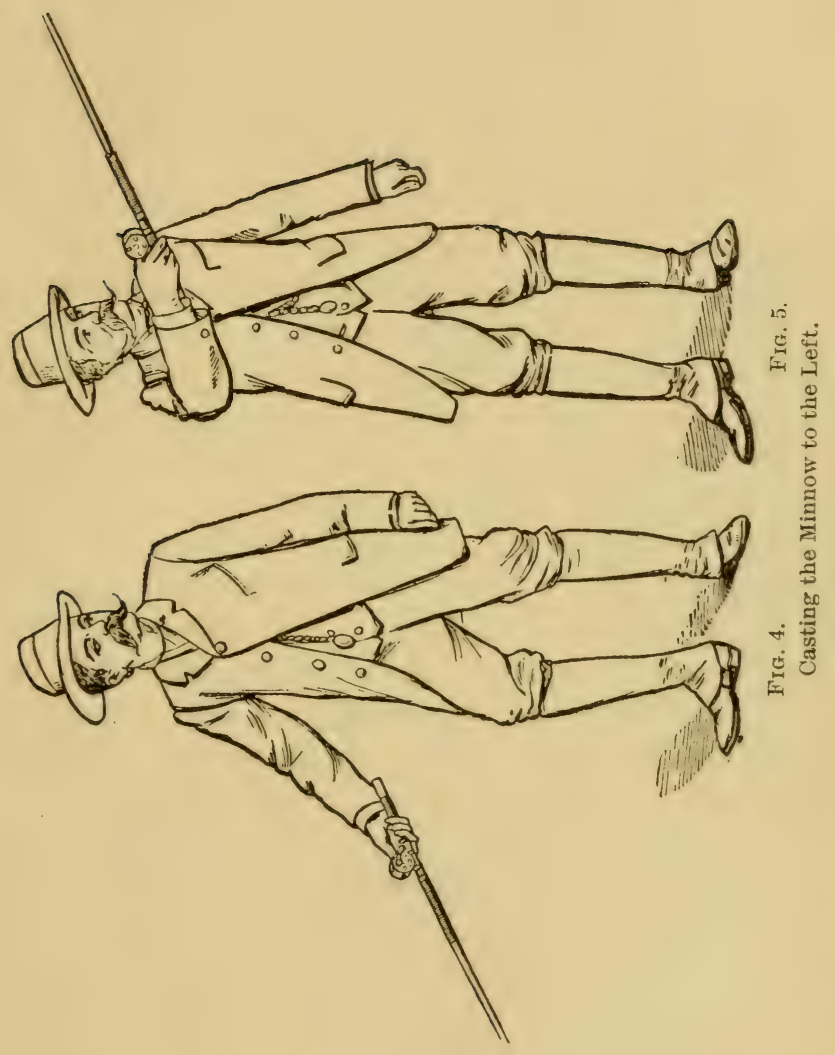


somewhat similar to the straight underhand pitching of a base-ball.

In making the cast, the right elbow should touch the borly, sweeping across it, and only leave it at the end of the cast, making the forearm do the work. At the end of the cast, the reel and thumb are upward, and the rod forms an angle of $30 \mathrm{deg}$. with the line of the shoulders $\mathrm{X} \mathrm{Z}$, and the minnow, instead of following the direction of the rod A D, as some might suppose, will, from the slight curve described by the rod during the cast, diverge toward the left, and drop at $\mathrm{X}$, when the thumb should immediately stop the reel by an increased pressure.

Casting to the right is just the reverse of the above proceeding. The angler being in the same position, bring: the right hand across, and touching the body, to a point in front of the left hip, the thumb and reel upward, but inclining toward the body, and the rod extending in the direction of the line A D, with the tip downward, as shown in figure 6 ; he now turns his face in the direction of the objective point $\mathrm{Z}$, inclines his body and advances his left foot in the direction of $\mathrm{D}$; and makes a cast from left to right, from below upward, and ends the cast with the right arm and rod fully extended in the direction of the line $\mathrm{A} \mathrm{C}$, as shown in figure $\%$, while the minnow takes its flight toward Z. This is a back-handed cast, and is somewhat analogous to the pitching of a quoit.

In making either cast the body should sway slightly and simultaneously with the rod arm, in the direction of the cast, to add force and steadiness; but on no account must the cast be made by main strength, as it requires but slight muscular exertion to cast forty yards; and on no account must the rod be carried further toward the line $\mathrm{X} \mathrm{Z}$ than an angle of thirty degrees, otherwise the bait will be thrown 


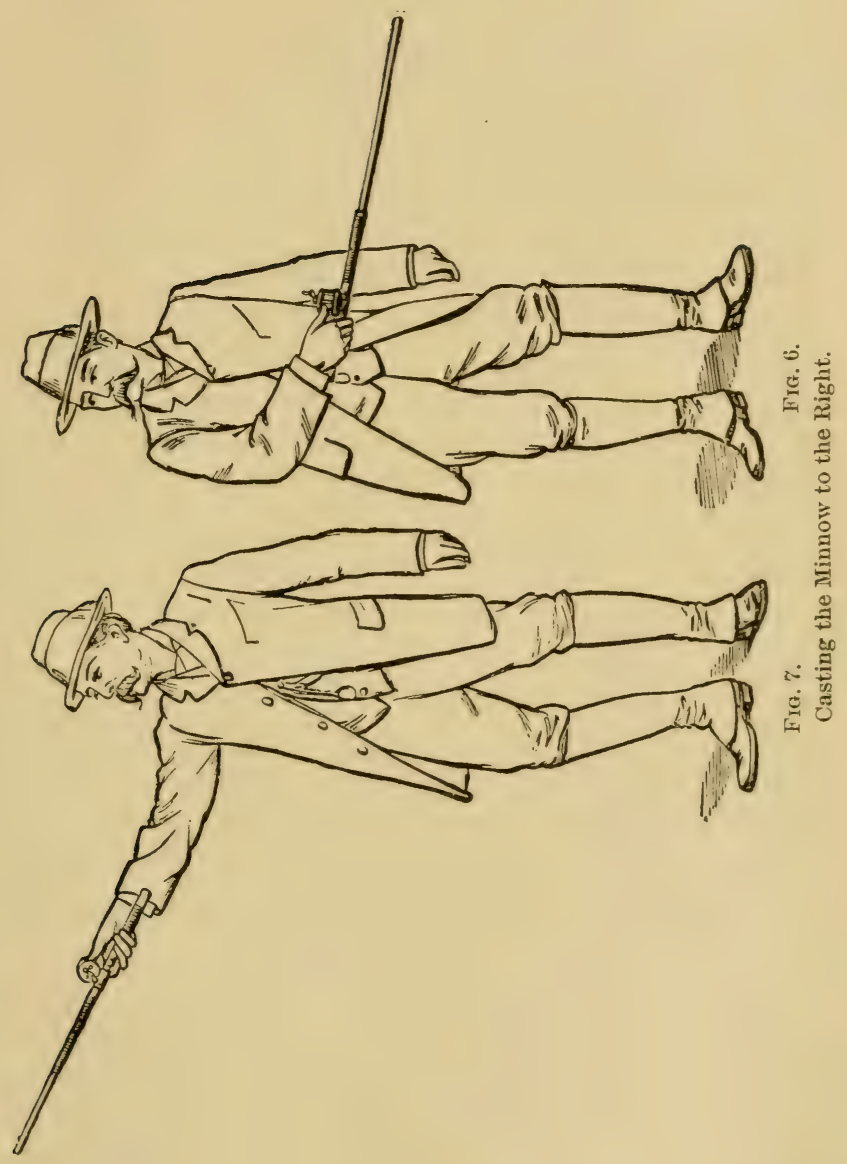


behind the angler. Particular care must be taken to give the bait an upward impulse as it leaves the rod.

The first cast that the beginner makes will be likely to throw the bait behind him, for reasons just given. He should, by all means, begin by making short casts, and lengthen them as he perfects himself by experience in managing the reel and controlling the cast. While but a few yards of line can be cast directly in front of the beginner, he should practice casting at various angles with the line $\mathrm{X} \mathrm{Z}$, to the left and right. He should avoid overhead casting, for that is the pot-fisher's method of throwing a bait, and is not only an awkward, but a very inefficient style of casting the minnow, and should not be practiced except where the reel is dispensed with, as in one mode of still-fishing.

At the beginning of the cast the thumb presses firmly upon the spool of the reel, until just before the tip of the rod gains its greatest extent or eleration, when the pressure is to be slightly relieved, so as to permit the release of the line, and allow the minnow to be projected in the direction of the cast. The exact time to lessen the pressure of the thumb and start the minnow on its flight, is almost a matter of intuition which can hardly be explained; how-. ever, the proper time is soon learned by practice, in which event, the "wrinkle" comes to be performed by the angler automatically, or, as it were, unconsciously.

The entire cast must be made so steadily and so regularly, and the rod held so firmly at the end of the cast, as to prevent entirely any undue swaying or bending of the rod, in order that the line may follow the direction of the minnow in its flight, smoothly and evenly, and untrammeled and unretarded by any vibratory motions of the rod. I trust I make myself understood here, for this is 
the most essential, and, at the same time, the most difficult feature, or portion, of the cast to explain, or acquire.

The thumb must be thoroughly educated to control the rendering of the line during the cast, and this can only be accomplished by continual and patient practice, in training the thumb to apply just the requisite amount of uniform pressure, to prevent the overrunning of the line, or back-lashing of the spool.

The beginner should make up his mind, in the first place, to keep his temper, and to exhibit no impatience at the frequent slipping of his thumb, and the consequent snarling and tangling of his line. The more calmly and philosophically he views these annoyances and perplexities, the sooner will he overcome the difficulties and become au fait in the management of the reel. The best instruction I can give him is to make the pressure of the thumb gentle, but firm and uniform, during the flight of the minnow, and to stop the revolving spool the moment the bait alights on the water by a stronger pressure.

These directions are as brief, plain and explicit, as it is possible to make them; they embody the main principles involved, and the novice, by a careful and practical application of them, can, by perseverance, soon become a good caster of the live minnow.

Should the angler be sitting in a boat, the directions just given must be somewhat modified to meet that condition; but they should be followed as closely as possible.

Casting the frog overhead, with a very short rod, as mentioned in Chapter Ix, is now practiced to some extent, but it does not appeal to the artistic angler, and requires no special directions. 


\section{General Instructions.}

If fishing from a boat, on a lake or large pond, the angler proceeds in his boat on the outside, or deep water side, of the fishing grounds, and casts in toward the feeding grounds, the oarsman rowing along rapidly or slowly, or holding the boat stationary, as circumstances demand. The boat being in deep water the fish are not so apt to see it, which is a great adrantage. The angler can cast in any direction and to any distance, greater or lesser, within the length of his line, as he may desire. He can cast astern and proceed as in trolling, or cast to either side, or forward, and by reeling in the line keep the bait in motion. It can readily be imagined how expert casting has so great an advantage over any other method of baitfishing, and that when once acquired it will never be relinquished for any other mode.

When a bass is hooked the boatman should pull at once for deep water, for the better management of the fish and to prevent its taking refuge among weeds, rocks, snags, etc. In deep water the fish has better play and more room, and the angler, having fewer difficulties to encounter, enjoys more thoroughly the ensuing contest and final capture and landing of his quarry.

If fishing from the banks of a stream, the angler should keep as near the level of the water as possible, or, still better, he should wade the stream when practicable. He should cast below the riffles, near gravelly bars, submerged roots or snags, weed patches and projecting rocks in the bed of the stream, and under shelving rocks on the banks. After striking a bass, he should lead him into deeper water if possible, or, at all events, away from dangerous places. After casting the minnow, and it alights at a favorable 


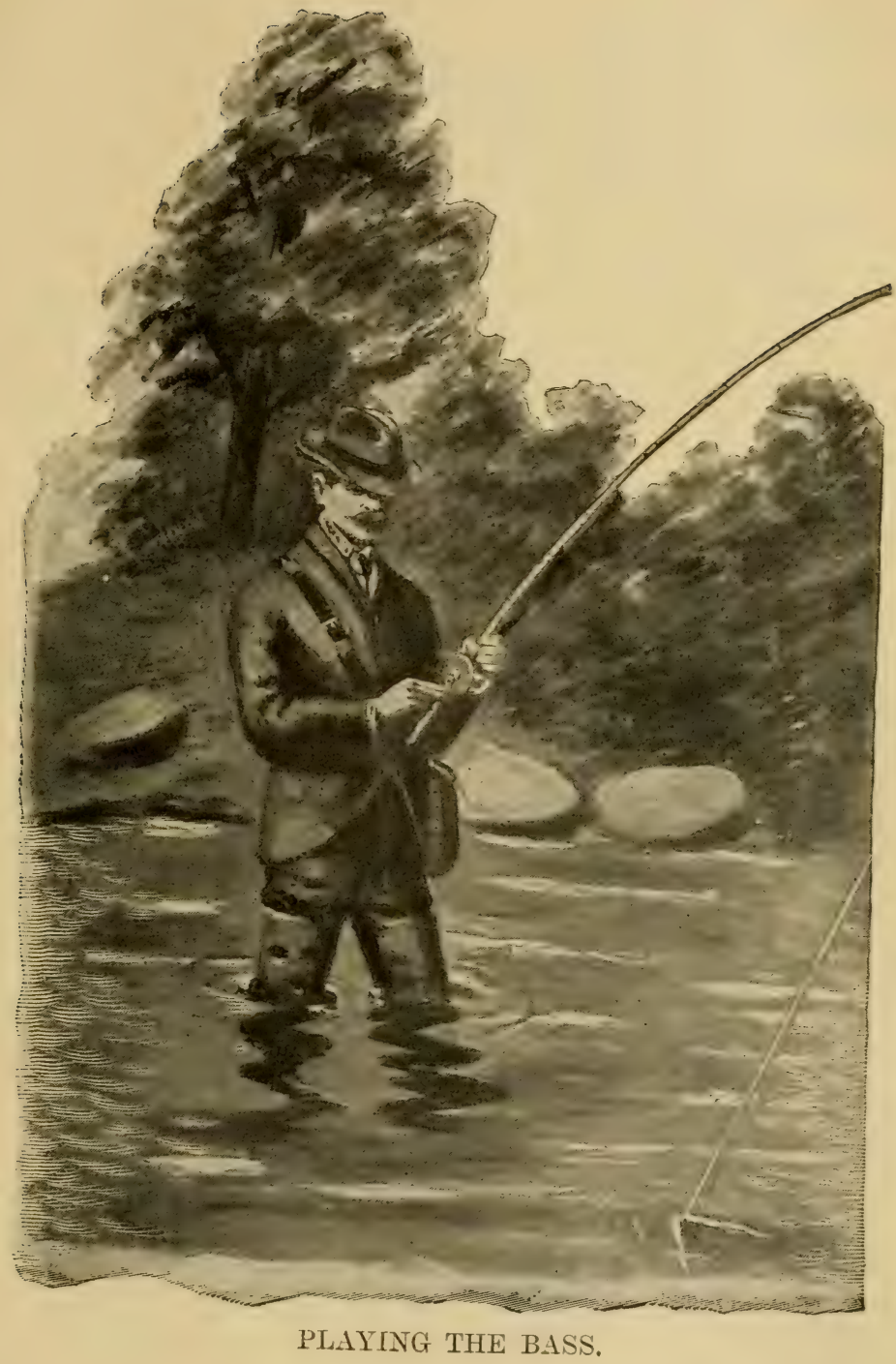



spot, it should be left for a longer or a shorter time, depending on the nature of the water fished, and upon the abundance, scarcity, and mood of the bass. As the line slackens, it should be slowly reeled until the entire line is retrieverl. Sometimes, when fish are plentiful and biting eagerly, it is best to make frequent casts. reeling in rapidly after each cast. especially in rather shallow water, so as to give a rapirl swimming motion to the bait.

When the bass takes the bait, the angler shonld let him have it from two to ten seconds. according to the mond of the fish. If he bites eagerly and wickedly, the angler may hook him at once: but if he seems shy, off his feed, and inclined to toy with the bait, let him have it a ferw seceonds: and give him line as he takes it, keeping the thumb upon the spool as a drag. howerer, so as to feel every motion of the fish. At the proper time the angler should cheek him by a stronger pressure of the thumb, when, if the bass pulls strongly and steadily, and sems inclined to run away with the bait. he should be hooked at once by at slight turning of the wrist. but not by a riolent jerk; or by " yanking" the rod.

If, howerer, upon checking the bals, he gives sereral tugs or a succession of slight jerkis. it is better to let him run a ferr seconds longer, for he has the bait crosswise in his mouth and does not feel the steel; finally, when he? pulls steadily, hook him as before described The bass should nerer be given time to gorge. or swallow, the bait.

From the time he first "bites" until he is in the landing-net, he should never be given an inch of slack line. under any circumstances. The rod must be held by the butt. with the thumb upon the reel, or. if the rod is held? in the left hand, the line must be held against the rorl, 
by the forefinger, which encircles it, and thus acts as a drag. The bass is, of course, hooked by the right, or rod hand, and the rod is held in that hand so long as the bass is inclined to pull steadily, or take line; but as soon as he shows a disposition to "let up," or turn toward the angler, the rod must be taken in the other hand, so as to leave the right hand free to use the reel. The bass should be made to feel, constantly. the suring of the rod, which should always maintain a curve. by the tip being held in an elevated position. The hass should fight for every inch of line, and the angler should take it again whenever possible. The fish must be killed on the rod.

should the bass break water, with a long line, merely let the rod straightem as he falls back. so as to slacken the line (but it should be recovered immediately when he strikes the water). for if he falls across a taut line he is almost sure to tear the hook out. If he breaks water with a short line, the rod may be elevated so as to keep the line above him, following him back as he falls into the water.

If there is danger of the bass getting to the weeds, or to the protection of snags, roots, rocks, ete. he must be stopped at all hazards. If the rod is a good one, and pliable, the angler must not hesitate to wive him the butt; this will bring him up standing. with no danger to a first-class rod; but if the rod is a stiff one, turning the butt to him will be most sure to break it; in this case it is best to keep the bass away from dangerous places by main strength and the natural bend of the rod. If fishing from a boat, great caution must be used to prevent the fish from running under it, as he will he sure to do if he has the opportunity; and should he suceeed. the rod must be quickly passed around the stern, or bow if the boat is not anchored, and 


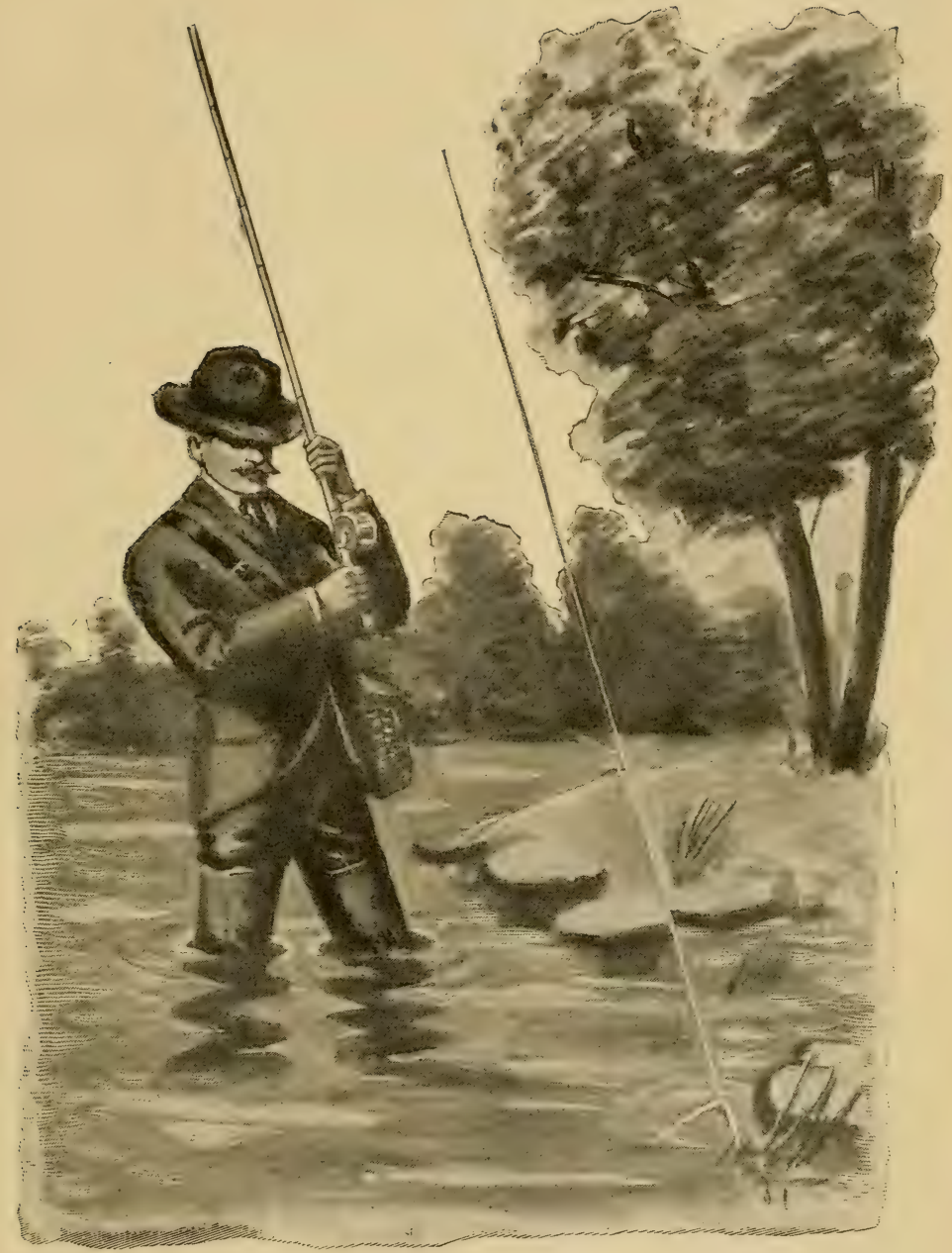

GIVING THE BUTT. 

the thumb at once released from the reel so as to allow the line to run out as rapidly as possible, otherwise a broken rod is the result.

When the fish is thoroughly exhausted, he should be landed, and not before. Most anglers attempt to land their fish too soon, thus curtailing their sport and endangering their tackle. The landing-net should be held several inches beneath the surface of the water, and held perfectly still, when the angler should bring the fish over it; then the net should be lifted quickly, and with one motion. The angler must never, himself, nor allow his assistant to, frighten the fish by lunging at it with the net, in attempting to secure it. More fish are lost in clumsy endeavor's to land them, than in any other way.

The angler should never be in too great a hurry to land his fish; for if he is well-hooked he can not get away, while if he is hooked in a thin or weak part of the mouth, there is a greater necessity that he should be gingerly played and tenderly handled, until he is completely "tuckered out," and turns up his side to the sun. There is never any thing gained by too great a hurry in bass fishing. On the contrary, "the more haste the less speed," is a maxim particularly applicable to this case.

In reeling in the line, whether playing a fish or retrieving the line, it should be guided on the spool of the reel by the left middle finger, when the reel is underneath the rod (as it always should be), or by the left thumb when the reel is used on top; it should be reeled on regularly from left to right, and from right to left, like sewing-cotton on a spool. This prevents that "bunching," or piling, and the subsequent tangling and snarling of the line, so common with beginners and careless anglers. It is just as 
easy to reel the line correctly, and in regular and uniform coils or turns, as to bunch it, if the novice begins right; after the habit is once acquired, he does it automatically or mechanically.

There are now reels made with automatic devices for level winding of the line, which is a boon to those who can not acquire the skill to guide the line with the finger or thumb. They are referred to in the chapter on reels. 

Copyright, $x 88_{3}$, by The Century Co.

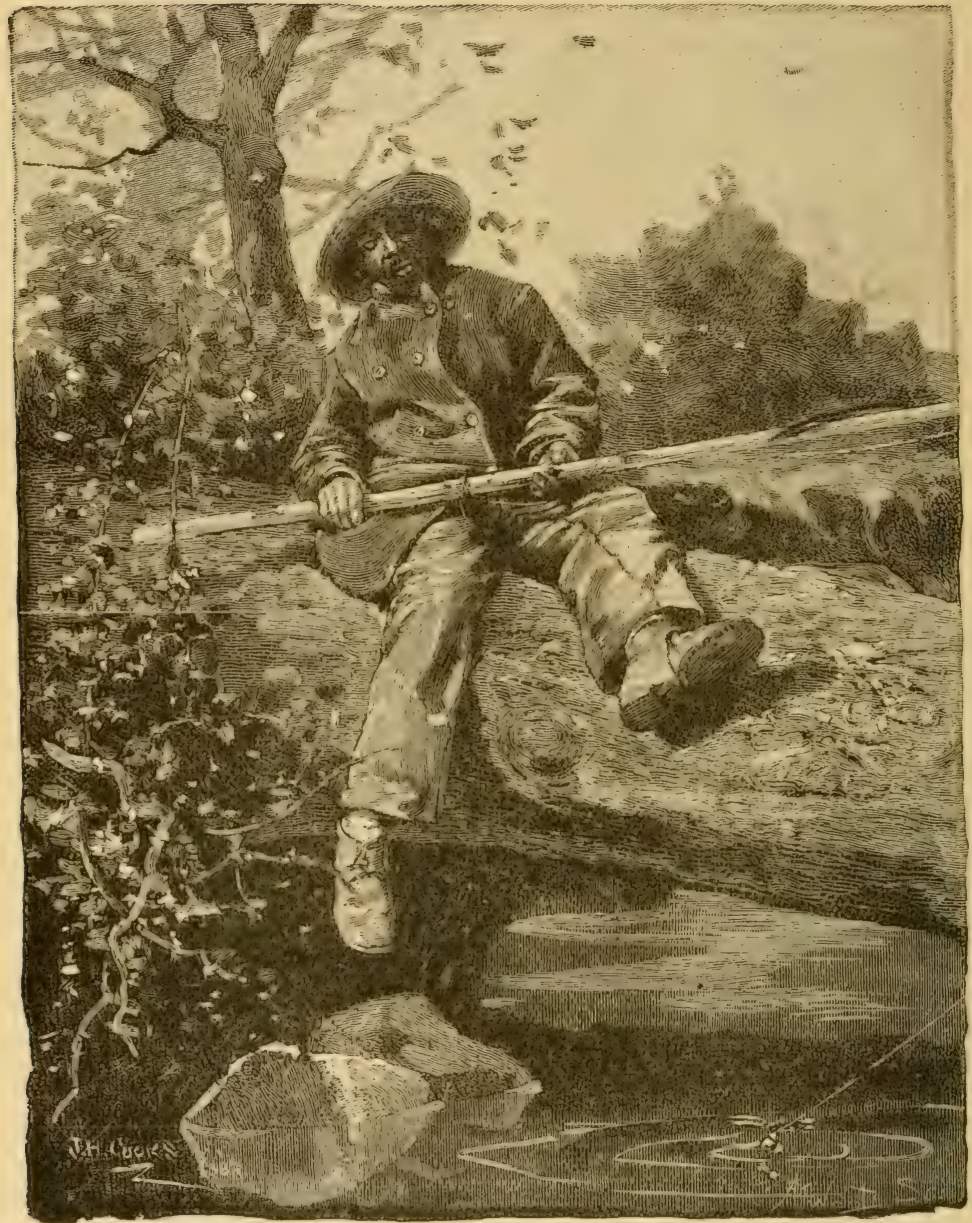

THE IDEAL STILL FISHER. 


\section{CHAPTER XXIII.}

\section{STILL-FISHING.}

"And if you rove for a perch with a minnow, then it is best to be alive, you sticking your hook through his back-fin; or a minnow with the hook in his upper lip, and letting. him swim up and down, about mid-water or a little lower, and you still keeping him to about that depth by a cork."-IzAAK WALTON.

Writat angler's heart does not leap when he thinks of his boyish experiences in angling! We were all "still-fishers" then. The boy who began fishing on a small trout stream, though, would not tarry long in one spot; he soon learned that he must be a roving fisherman to fill his string.

But the boy who began on "sunnies," or red-eyes, or "brim," or gudgeons, or even bull-heads or suckers, imlibed his first lessons in the virtue of patience during his pin-feather days of angling.

What finished, artistic fly-fisher but would gladly hark back to those golden days! What a monument of patience he was, and what a fatalist as to luck, and what a firm believer in the secret, unwritten mysteries of the art, as he sat motionless on a rock, or perched upon a gnarled root, or lay prone upon a grassy bank, watching his float with all the eagerness and expectancy of a kingfisher on his dead branch, or an osprey on his cliff!

And how well he knew every "hole," and every submerged rock, and every snag; and just "how deep" to place his float, and just how long to let it run before "yanking" the fish or his hook into the limb overhead, or into the bush behind him! 
And how well he knew every muskrat's run, and every kingfisher's perch, and erery bank-swallow's hole; and, though watching his "cork" nerer so intently, how he had an eye for every water-snake, and turtle, and bull-frog that stirred within ten rods of him!

And when an unlucky muskrat, or kingfisher, or snake, or turtle, or frog showed itself, how he would lay a rock on the butt of his "pole," and start in quest of it; and how these mammalian forays, and ornithic sallies, and reptilian assaults would rest him; and with what renewed zest he would repair to his fishing, and with what consummate and enduring faith he would spit on his hook, and resume his waiting and watehing!

Oh! bright, sunny, golden days of youth! How farhow very far we have traveled down the stream since then! We may look back, and through the gaps in the trees, and over the low hills catch a sparkle of the stream behind and above us; but, alas! we can never go back - never return! Our course is ever on, on - and down, down - and the stream is ever widening and growing deeper, until it will soon be lost in the great gulf of the unknown!

I have much sympathy, and great respect, if not downright enry for the still-fisher. There is a jurenility, and a childish faith in his methods that are totally unknown, or utterly lost to the blasé old hand at fly-fishing, or minnowcasting.

II is tastes are as simple, his expectations as great, his anticipations as easily satisfied, and his enjoyment as ample as in the pin-hook days of the best of us. He is, indeed, but a child of larger growth.

His life may have been saddened with the experience of time - his hands hardened with years of toil - his heart seared with the inhumanity of man - but he still retains 
the innocence and freshness of his youth when seated at the waterside with the "peeled sapling" in his stiffened hands - the voice of the stream whispering in his ears - its moist breath stealing through his grizzled locks - and its rippling smile flashing on his tired eyes!

Still-fishing is the most universal mode of angling for the black bass. As the name implies, it consists in throwing in the baited hook, and waiting patiently for "a bite," the angler, meanwhile, keeping himself and rod as still as possible. Fly-fishing is surface fishing; casting the minnow is both surface and mid-water fishing; while still-fishing combines mid-water and bottom fishing. In fly-fishing and casting the minnow the bait is kept in pretty constant motion, while in still-fishing the bait is left to itself, or "still," for a longer or shorter time. Still-fishing on streams is best practiced from the banks, while on lakes or large ponds a boat is necessary.

\section{TACKLE.}

Still-fishing is often practiced without a reel, and sometimes without a rod, a hand-line merely being used. When no reel is employed the rod should be quite long and light, the best being a cane pole from twelve to fifteen feet in length. When the reel is used (as it always ought to be) the rod recommended for casting the minnow is the best, though most still-fishers prefer a longer rod, say from ten to twelre feet, as they are not proficient in casting.

The length of the line for still-fishing depends upon the character of the rod. Where no reel is employed it should be of aloout the same length as the rod; when the angler uses a reel, but is indifferent at casting, a line of twentyfive yards is sufficient; but when the regular minnow-rod is used by a good caster, fifty yards, as in casting the min- 
now, should be used. The line in each instance being the same as recommended for casting the minnow, except where no reel is used, when the smallest size twisted silk line, No. 1 , is the best.

Still-fishers usually employ the float and sinker, and they may be used or not, according to circumstances, though one of the chicfest delights of the still-fisher is to watch the maneurers of his float. Where the stream is shallow and full of snags, or the bottom covered with moss or grass, a float is necessary; and where the current is quite swift, or the water deep, and the bait-minnow large and strong, a sinker must be used to keep it beneath the surface.

\section{Baits and Batting.}

While a minnow is the best bait for casting, other baits, as the helgramite, crawfish, frog, cricket, grasshopper, etc., are as good, and sometimes better, for still-fishing. As a rule, the bait that is the most plentiful in the waters fished will be found the most successful. The helgramite is a capital bait, either early or late in the season, when the bass are on the ripples on in shallow water. It is a flat, dark, repulsive-looking worm. some two or three inches long, and a half-inch wide (the larra of the horned cory(dalis), and is found under boulders. flat stones, decaying timbers, etc. in shallow streams. It is variously called helgramite, dobson. hellion, kill-devil, grampus, crawler, etc., and is best hooked by passing the hook under the cap covering the neck, from behind forward, bringing the hook out next to the head.

The crawfish, especially when casting its shell, when it is called "peeler" or "shedder," is a good bait. In its usual state it is best hooked through the tail; peelers can 
be hooked through the head or body. Grasshoppers, crickets, frogs, etc., are nsed with rarying suecess in still-fishing, and sometimes the humble "wum."

\section{General Instructions.}

As the still-fisher never casts his bait very far, it is highly important that he keep as still and motionless as posisile ; and, if fishing from a boat, must avoid striking it with his feet, his rod, or the oars, as such sounds are heard rery distinctly by the fish. He should fish toward the sun, so as to keep his shadow behind him. He should keep his line as taut as possible, with his thumb always upon the spool of the reel (if he uses one), and as the line becomes slack, should reel it in.

In fishing a lake or pond, the still-fisher anchors his boat in a farorable spot, which should be in rather deep water, just off a shoal or har. ledge of rocks or point of land, or near beds of rushes or lily-pads, so as to fisin between the boat and the feeding grounds, that is, between deep and shallow water. and near enongh to cast his bait quite up to the haunts of the bass, whenever necessary.

If his minnows are lively and strong, and carefully lookerl. it is artrisable not to make frecquent casts. but rather to suffer the bait to remain, so long as it keeps in motion. for a lively minnow will attract a bass anywhere within thirty feet, in tolerably clear water. If helgramites or crawfish are used for bait. they must loe kept gently moving, at times, by the rod.

The management of hooking, playing. and landing a bass is just the same as described in the preceding chapter, except where a reel is not used, in. which case the bass should be killed on the rod, all the same, though the angler must use a great deal of judgment in managing his rod, 
to thoroughly enjoy the sport, which is considerable where the rod is long, slender, and light.

He should lead his fish, at once, into deep water, where it must be held until tired out. It should be kept in midwater, not suffered to go to the bottom, nor encouraged to approach the surface. He should lead it to and fro, to the left and right. whenever possible, for by keeping the fish in constant motion it soon tires him out, and subserves, to some extent, the purposes and uses of a reel.

In still-fishing a stream. the angler should stand, or sit, as near the level of the water as possible, never fishing from a bold bank or other elevation. unless well screened from the observation of the fish. He should keep quiet and still, when he may possibly be mistaken for a stump or other inanimate olject. He should leave his bait in the water for long intervals. only moving it occasionally, by slow. cautious and gentle manipulations. and in every other respect remember that he is "still-fishing." and govern himself accordingly: for too much caution can not be exercised in this mode of angling.

The noisy "fishing party"." which indulges in loud talking. shouting. and laughter. and has a "good time" generally: no doubt thoroughly enjors itself in its own way, but will take but few fish; it is the "lone fisherman" who is always successful, for obvious reasons.

\section{A Retrospection.}

An old negro house-servant and a bright-eyed, flaxenhaired boy of eight summer's sat side by side under a milldam, on a Kentucky stream. fishing. The old man was engaged in earnest conversation. to which the lad was an eager listener, save when interrupted by the pulling out of a fish or the re-baiting of a hook: 
"Yaas, Percy Lee, it's jist wasteful 'stravagance for yo" paw to buy sich larish, shiny fish-poles an' silvah recl contrapshuns dat run riot wid his money. All de fish in do Elkhorn wouldn't 'gin to pay intrust on 'em. He's de beatenes' man for 'stravagance I ebber see.

“De bestes' fish-pole is de strettes' an' slimmes' ellum saplin' you kin fine; cut in de fall in de lite ob de moon, an' peeled in de shade, an' put up in de lof' nex' to de calbin chimbly all wintah. An' de bass an' chan'l-cat won't know wedder it cos' two cents or de price ob a yearlin' mule, case you yank 'em out so quick dey ain't got time to tink 'bout it."

"Yes, but Uncle Enoch, papa don't like to yank 'em out so quickly."

"No, honey, an' dat's wat beats me. He jis" goeș a-wadin' in de water - an' he'll done ketch his sleff o' rheumatiz one ob dese days-a-whippin' his lil' shiny switch, an' a-flippin' his fiddle-string line wid lil' teenty fedderflies, an' de bass ketch holt, an' ben' an twis' de lil' pole, an' run off wid de line - an' Mars' Dick wind 'em up agin, an' de bass pull out de line agin. an' jump out to see wat gwine to happen nex', an' dey hav' mo' fun dan a bag full o' monkeys at de circus."

"But papa says he used to fish with cane poles and minnows, Uncle Enoch."

"Yaas, Percy Lee, wen Mars' Dick was a lil" lam', jis" like yo-self, he use' to sot in dis same place wid me. an' laws-o'marcy wat gorms o' bass, an' new-lites, an' chan'l cats we use' to snek out! But aft-a-wile he growed up an' den he marri'd Mis' Alice, an' dat quiled his fishin'.

"An' den de wah cum on. an' yo' paw went away to fite wid de sogers, when yo' was a teenty lil' baby; an' Mis' 
Alice use' to cum heah a-fishin' wid me, an' Liza Jane wud brung de baby. But Mis' Alice nebber cud larn to fish; she jis' kep' me a-tellin' how yo' paw use' to fish when he was a lil' boy, an' wat he wud say, an' wat he wud do; an' she'd des go an' sot on dat ole sycamo' root - whar you settin' now - whar he use' to fish; an' de big tear-drops wud roll down her pink cheeks ebery time I ketch a fish, an' she wud run an' grab de baby - dat was you - an' hug you up, an' kiss you, and den want me to begin all ober agin. Iou see, honey, she was so chicken-hearted she cuchn't bar to see de recl-eres an' new-lites a-floppin' on de hook. In' no matter how offen I 'splained to her how Mars' Dick use' to ketch 'em, an' how I ketch 'em, she des was too tender-minded to larn.

"Den yo' jaw cum home aftah de wah, an' brung a lot o' highfalutin noshums wid him. An' de nex' summah a Yankee kurnel fum 'way up) norf cum a-risitin' an' he showed Mar', Dick how to fish wid shiney switch poles an' fedder-flies.

“An' now Mars' Dick drags Mis' Alice wid hirn, an' she goes trapesin' 'long de sho' wid de haskit - an' she'll ketch her deff o' dampness sum day, you hear me - an' she watches him sling dem fectler-flies, an' claps her han's an' lafis, an'sez: 'Good boy; well dun, Dick!'

"In wen de bass is tucker'd out Mars' Dick shuv a little roun' net under hims an'raps him on de haid, an' totes him a-sho'; an' den him an' Mis' Nlice sot dar an' look at it, an' yo' paw smoke his pipe, an' he tell. Mis' Alice 'bout de fish jis' lak I use' to talk to him when he was a lil' lam' like yo' ownself; an' dey dun spoon jis' as foolish as 'fo' dey was marri'd.

“An' Mis' Alice she meks de fedder flies fer Mars' Dick, now - she nebler did cotton to wums, an' crawfish, an' 
crawl-debbils - an' she nebber cries now when de bass snaps 'em. But, honey, he can't fool de chan'l-cat wid 'em; no, my young marstah, Mistah chan'l-cat is too wise in dis gen'ration o' vipers fer dat. He wants a fat soft craw, or a piece of fresh libber. Gib him vict'ry or gib him deff. "Cum, honey, we dun got a good mess o" pan-fish, less be gwine home; Mistah crow dun lite out fo' his roost long time ago." 


\section{CHAPTER XXIV.}

\section{TROLLING.}

"And then you are to know that your minnow must be so put on your hook that it must turn round when 'tis drawn against the stream."-IZAAK WALTON.

\section{Trolling WITH THE RoD.}

Troblise with the rod, and with the artificial fly, the live minnow, or the spoon for bait, is capital sport; and is a very popular style of angling on the lakes and lakelets of the western states. It is more en regle than still-fishing, and is, besides, more exciting sport, possessing advantages over the latter method in several respects.

The angler ean fish with a long line, even though he he indifferent at casting; for. as the boat moves along the line can be pulled off from the reel, yard by yard, with the hand, while the resistance of the bait, in the water, takes it from the rod. The bait being in constant motion is more likely to be seen and taken by the fish than in stillfishing; while the great length of line takes the bait so far from the boat as to remove or quiet any suspicions or apprehensions of danger on the part of the wily bass.

Then, the boat not being anchored, as in still-fishing, the boatman can faror the angler in many ways when playing or landing his fish. Then, again, in moving orer so much and so great a variety of ground, the angler is more apt to find where the bass are feeding, and thus to know just the character of the ground and depth of water to try successfully on each particular occasion. And, lastly, it 
secures a constant change of location, and adds enough of the spice of variety to satisfy the most impatient angler.

The minnow-casting rod, previously described, is the one best adapted to this or any other mode of bait-fishing, though any light and pliable rod, not exceeding ten feet in length, will answer. A stiff and unyielding rod should not be used, for the sudden and violent "bite" of the bass, in this method of angling, with the rod ever bent, and taut line, would be very likely to break it, unless the rod were of the hoop-pole pattern.

The only lines admissible here are the braided raw or boiled silk line, and the braided linen line; twisted lines can not be used at all on account of their kinking. The caliber should be a size larger than recommended for casting the minnow, which, in silk lines, would be sizes $\mathrm{F}$, or No. 4, and G, or No. 5 ; and, in linen lines, G, or No. 5. The length should be fifty yards.

It is best to use a leader about six feet long, with either flies, the minnow or spoon. The float should not be used. One or two swivels are necessary; but, usually, no sinker is required.

If artificial flies are used for the troll, a gut-leader, six feet in length, and two flies, may be employed; or, a ninefeet leader, and three flies, as preferred by some. The flies should be placed about three feet apart on the leader. An attractive combination of varieties in the flies should be observed.

A very good assortment would be for the tail-fly a "coachman;" for the first dropper a "grizzly king," and, lastly, an "Abbey." Another good troll would be a "professor " for tail-fly, a " Montreal " next, the third a "brown hackle." But, of course, other flies will be used by the angler as found more attractive and killing, for different 
water's often repuire different flies, in trolling as well as in fly-fishing.

Three split shot, No. 1, should be placed at equal distances along the leader, so as to keep the flies submerged from one to two feet below the surface. The boat should be propelled quite slowly in trolling with flies, so as to permit their sinking to the proper depth, and, likewise, to enable them to be easily seen by the fish.

If the first bass hooked takes an upper fly, hy playing him judiciously and cautiously, one, or even two, additional hass may often be induced to take the lower flies, though I do not advise this plan with a light rod; one at a time will afford better sport.

If a spoon-bait is to he the lure, only the smallest sizes, as fly-spoons, or trout-spoons, should be employed, with a single hook. Lsually, no sinker will be needed, but one or two swirels should always be used - one next to the spoon, and the other several feet above it. In trolling with the spoon, the boat should move at a sufficient rate of speed to anse the spoon to revolve rapidly a foot or two beneath the surface of the water.

In trolling with the live minnow, but one hook should be used. Give a wirle berth to the English abominations known as spinning-tackle, gangs, traces, etc., consisting of from three to a dozen hooks, arranged in groups of three, with single hooks for impaling the minnow. A single hook is sufficient for all purposes. The live or dead minnow may be hooked through the lips; or, perhaps, the best way for trolling. with a dead minnow, is to pass the hook through the mouth and out at the gill-opening, then carry it back and insert it just behind the dorsal fin; a needle armed with a strong thread is then passed through the lips of the minnow, and tightly tied to the snell, this obviates 
the use of the lip-hook; a minnow will spin as well hooked in this way as with the most approred spinning-tackle.

The angler, with his boatman, in trolling with the rod, proceeds in a boat orer the fishing-grounds, with from twenty to thirty yards of line out. The rod must be held? with the tip elevated, so as to keep it constantly curved, and the thumb should be applied to the spool of the reel so as to be ready at any moment for the violent rush of the bass, for he bites very wickedly at the moving bait. The fish must be hooked at once, though he usually fastens himself. If the angler has a long line out he must reel in his fish as soon as possible, until he has him within proper bounds, when he can kill him at his leisure. The manipulation of the bass after he is hooked is just the same as described in the chapter on casting the minnow, to which the reader is referred.

It is useless to troll in deep water. far from shore; it should only be practiced in water from three to ten feet deep, following the trend of the shore as far as possible, where the proper conditions exist, which are giren in a previous chapter.

\section{Trolling with the Hand-Line.}

Trolling with the hand-line is a rery tame and simple mode of angling; in fact, is the most simple method practiced, there being no skill, whatever, required in luring or in manipulating the hass after he is hooker. It is a very questionable style of sport, at best; and considered in this light, is exceedingly flat. and sarors strongly of pot-fishing. It is indulged in on lakes, ponds and hroard rivers. mostly by boys and those unfortunates who can not, or will not, learn to handle the rod. 
With a good breeze and a fast-sailing boat, trolling for bluefish, weak fish. Spanish mackerel, and other marine fishes, with hand-line and squid, is exciting sport; but, on the bosom of a quiet lake, trolling for black bass with hand-line and spoon is a cruel pastime and a wanton destruction of a nolle fish. It is only excusable when in camping out, without suitable tackle, and when, like the boy digging at the tenantless woodchuck hole, one is "out of meat," which. in southern parlance, constitutes "a ground-hog case "; in this event, perhaps, the end justifies the means.

The necessary tackle for this mode of angling consists of a strong hand-line of linen or cotton, from fifty to seventy-five yards long; braided lines are to be preferred, as they do not kink. The line should be large enough to prevent cutting the hands, and, at the same time, to withstand the dead strain of a lively fish. Sizes C, or No. 2, and D, or No. 3, are the best and most suitable.

Any of the numerous revolving spoon-baits, or spinners, will answer with or without the so-called "fly," or tuft of feathers, or braicl. for it is the loright metal spoon that lures the hass, and it can not he made more attractive for handtrolling by the addition of feathers, braid, etc.

The ordinary original tin or brass spoon, with single hook soldered on, is alonut as good as any of the later inventions. A single look is certainly preferable to the groups of two or three. misually attached to spoon-baits, the latter often being crushed or broken by the jaws of a large fish, to say nothing of their cruelty, as mentioned on a preceding page.

Small spoons are more suceessful than large ones, for bilack bass. In the absence of a spoon-bait, the floor of the mouth of the pickerel, cut into the semblance of a fish, 
is tough, white and glistening, and is a good substitute; a similar strip, cut from the belly or side of a fish, also answers a good purpose. One or two swirels should always be used with trolling-baits; a sinker is seldom necessary.

With this simple outfit, early in the season, hefore the aquatic weeds and grasses are fully grown, this morle of fishing is quite successful. The method of procedure is as follows:

The angler sits in the stern of the boat, and, while the oarsman rows at a moderate rate of speed along and orer the feeding-ground, he runs off forty to sixty yards of line; the spoon revolving gracefully beneath the surface proves an effective lure. A violent jerk on the line announces the fact that an unfortunate bass has "hooked himself;" often he will leap into the air, vainly endearoring to shake the glittering deception from his jaws, but his efforts usually serve to fix the several hooks more firmly in his mouth, and provided he does not erush them or tear them out and escape, he is "hauled in," hand nver hand, by muscle and main strength, without a single chance for his life - dragged to an ignoble death by a hand-line and spoon.

Many years ago I was attracted to Gogebic Lake and Eagle Waters in northern Wisconsin to inrestigate the socalled "razor back" black bass of Gogebic. which was sairl to be a new species, and the mascalonge of Eagle Waters. I found the former to be only small-mouth hass infected with tape worm, and the latter to be a true mascalonge.

At that time Gogebic Lake was somewhat famous on account of its great numbers of black bass, and the ease with which they could be caught. While there I witnessed scenes and heard of acts that should bring the blush of 
shame to the cheek of the most hardened; and yet they were perpetrated by men calling themselves anglers, or at least fishermen, for there is a difference in degree as well as in kind of those claiming allegiance to the "gentle" art.

On the first evening of my arrival I saw two large piles of black bass, enough to fill several barrels, burnt by the guides at the edge of the lake. Nine-tenths of them were caught with the hand-line and trolling-spoon by anglers Hearen, save the mark! - who were fishing for count, or rying with each other as to who should bring in the greatest number.

It is no excuse to say that the hass were there to be canght, or that the parties knew no better. They would have resented warmly any imputation that they were other than humane, conscientious sportsmen. I will give a scrap of conversation that I overheard on the hotel veranda that evening; the reater can then judge for himself and draw his own conclusions.

"Well, old man, what luck to-day?"

"Bully! I took in out of the wet a hundred and twentyfive hass, and would have had more but I lost all of my spoons. Then I went ashore and shot three or four 'porkies' with my pistol!"

Now here was a bloody-minded butcher who was not content, with the help of his boatman, with slaughtering over a hundred bass with the spoon, but who had the effrontery and insolenee to brag of it before gentlemen; and to cap the climax of his truculence he boasted of shooting several innocent porcupines, a harmless, clumsy animal that can not get out of one's way, and whose only means of defense is to hump up its back and erect its quills; an animal that a sportsman never thinks of molesting.

"Pshaw!" chimed in a young man, who with several 
companions had been camping down the lake for a week, "we shot nearly fifty in a week near our camp; they gnawed the axe-handle and chewed up a pair or two of boots, and we started in to clean 'em out!"

And these young men had probably time and again responded to the commandment, "Thou shalt not kill," with "Lord, have merey upon us, and incline our hearts to lieep this law."

Now, I do not pose as an example, or as being any better than my fellows, for I am not, but I do hold that the wanton lilling of the meanest creature is murder. At the same time, I can kill any animal - mammal, bird or fish with clean hands and with a clear conscience, when slone in a sportsmanlike manner, and when it can be utilized.

I assure the reader that the scrap of conversation given abore is a mild sample of what I actually heard that erening. Some boasted of killing even more bass than the individual mentioned, but I believe they added lying to their other accomplishments.

Then there were grouse and deer killed out of season does still in milk, and grouse-hens with half-grown bronds - but enough; these men were what they scemed, mere pretenders to the name of angler or sportsman, such as one is apt to meet at any summer hotel where there is fishing or shooting; men who under the guise of innocent sport indulge their thirst for hlood and murder; men who are set and confirmed in their ways, and for whom there is no hope of improvement or reform.

But there are new hands who do these things thoughtlessly, and by the force of bad example. and it is for their benefit that I have written what might otherwise be deemed out of place, here. 


\section{CHAPTER XXV.}

\section{SKITTERING AND BOBBING.}

"Then, if you get a grasshopper, put it on your hook, with your line about two yards long: standing behind a bush or tree, where his hole is, and make your bait stir up and down on the top of the water."-IZAAK WALToN.

\section{SkitTering.}

"Skitemering" is best practiced with a long and lighì natural cane roul. from twelve to fifteen feet long, and a strong line of nearly the same length. No reel is used, for, like "bohbing." this mole of fishing is only successful in grassy and weelly situations, where the water is comparatively shallow, notably, in the lagoons and bayous of the extreme south, and where the fish must be landed as soon as posible after being hookerl. To the end of thes line is attached a small trout-spoon, or the slitteringspoon, which is still smaller, being the smallest revolving spoon made.

The molus operandi is as follows: The angler stands in the bow of the boat. which is pardded or poled by the boatman as noisclessly as possible, just outside of or along the chammels of clear water. among the patches of rushes, lilypark or bonnets. 'The angler, by means of the long rod and short line, skitters or skips the spoon along the surface of the water with a jerky or vibratory motion, eausing it to spin and slance close up to the edges of the weeds, where it is viciously seized by the bass, who has been lying in wait among the water lettuce, or under the broad pads of the water-lily, for just such an opportunity. 
The angler has now no time to lose, but must rapidly draw the bass along the surface of the water to the boat, into which he must be lifted at once, for he is as good as gone if he gets below the surface, among the weeds; nor must he be allowed to leap into the air with so short a line, but he must be dragged quickly along the surface, with his head above the water, until the line can be taken hold of close to the hook, or the finger hooked in the gillopening, and the fish dexterously lifted over the side of the boat. A landing-net is seldom used.

In such situations, skittering is exciting sport, and is not without its attractions. The bright glancing spoon, the expert and skillful management of the rod, the mighty rush and splash of the bass as he snaps up the shining bauble, and his subsequent lashing and floundering as he is irresistibly drawn toward the boat, vainly endearoring to get either in or out of the water, and the final adroit manner of landing him, go far toward making this a legitimate sport, as it undoubtedly is, in the localities mentioned, inasmuch as reel-fishing can not be practiced for reasons before given.

\section{BoBBING.}

"Bobbing" is another style of angling peculiar to the section of country just mentioned, and though it can not be regarded as so artistic or legitimate, it is far more killing than skittering. It is a mode of fishing especially adapted to the waters of the Gulf states, where it is much practiced. The implements for bobbing are few and simple, consisting merely of a strong rod from twelve to fifteen feet in length, two or three feet of stout line, and the "bob," heretofore described in Chapter xvIr.

I can not explain this method of angling better than 
to quote from Bartram, whe wrote of the "trout" (black bass) of Florida and the way of taking them with the bob, in $1 \% 64$, as follows:

"They are taken with a hook and line, but without any bait. Two people are in a little canoe, one sitting in the stern to steer, and the other near the bow, having a rod ten or twelve feet in length, to one end of which, is tied a string line, about twenty inches in length, to which is fastened three large hooks, back to back. These are fixed rery securely, and tied with the white hair of a deer's tail, shreds of a red garter, and some parti-colored feathers, all which form a tuft or tassel nearly as large as one's fist, and entirely cover and conceal the hooks; that is called a 'bob.' The steersman paddles softly, and proceeds slowly along shore; he now ingenionsly swings the bob backwards and forwards, just above the surface and sometimes tips the water with it, when the unfortunate eheated trout instantly springs from under the reeds and seizes the exposed prey."

I have many times seen the bob used in Florida just as described by Bartram more than a century ago, and it is just as effective to-day as it was then. If there is any thing in the notion of certain angling authorities, that fish after a time become educated or accustomed to certain artificial baits, as flies, etc.-becoming fir'st suspicious, and finally refusing them altogether, then the black bass of Florida must be very dull of comprehension, must have sadly neglected their elucational privileges and opportunities, or else the said "theory," like many another from "across the herring pond," originated in the fertile brain of some unfortunate angler to account for an empty creel.

Once, when in Florida, two of us had gone several miles up a river one day for deer and turkeys. When the sun was nearly down we had one deer, and had located several more. and also had found a turliey-roost near by. We con- 
cluded, instead of returning down the river to camp, to build a fire and sleep under a tree, so as to be on the ground at daylight in the morning, with the strong probability of another deer or several turkeys.

We did not wish to cut into the venison, as we intended to give it to a "cracker" family near our camp, the head of said household being down with "the shakes." We had. only the liver of the deer for supper, and wishing to vary it with some other viand, concluded to try for a black bass in the river.

Happening to have a fish-hook in my pocket, I cut off a piece of the deer's tail, and made a "bob." Then, cutting a long, slender pole, and tying the bob to the end with a piece of strong twins some three feet long, we got into the boat, my comrade paddling and I manipulating the bob.

The sun was at the edge of the horizon, a huge ball of crimson fire, the atmosphere being somewhat smoky from fires kindled by the Indians to burn off the old grass in order to make a fresh "burn" for the deer to feed on.

The river expanded just above into quite a shallow lake, well grown with lily-pads, bonnets and saw-grass, through which meandered several channels of open water. As we approached the lake, toward the sun, it seemed that these channels were filled with liquid fire, and the occasional leaping of a mullet, or dropping in of a small alligator, served to heighten this effect, and to simulate sparks and flames. The pure white wings of the egret, as it flitted over the water, seemed like miniature sails on a rubescent sea.

As my companion noiselessly paddled the boat along the fringe of rank grasses and luxuriant aquatic regetation, I danced the bob along and over the water, now low, now high, and now dipping in the water - skimming. leaping 
and flying - till it seemed an uncanny thing, as indeed it was, a cervine ignis-fatuus, a hirsute will-o'-the-wisp.

Several bass rose to it, and swirled at it, until one more active than the rest grabbed it by a vicious lunge, and the hook was firmly implanted in his jaw. It was the work of but a minute to land him in the boat, and he was soon joined by another, when we repaired to our camp-fire which was now throwing a cheerful, ruddy light on the pines and palmettoes.

This was one of the occasions when the "bob," or the skittering-spoon, or the trolling-spoon may be legitimately nsed; for we not only took great pleasure in the novelty of the sport, but we enjoyed a rich repast that night after roasting the hass in their scales in the hot ashes, broiling the deer's liver on a split stick, grilling a few crackers of hard-tack, and making a cup of hot, strong coffee - leaving enough for a cold breakfast at daylight in the morning. 


\section{CHAPTER XXVI.}

\section{CONCLUDING REMARKS.}

THene is a right way, and, per contre, a wrong way, to do every thing. I have endearored in the preceding pages to point out the right way of doing things pertaining to angling, but I feel that my duty would be but half accomplished did I not give some advice relative to the proper use and care of fishing tackle, before taking leave of my reader. I am the more impelled to do this from the fact that I have seen so many fine and elegant rods, reels, and lines improvidently ruined, through sheer carelessness in most instances, and through ignorance in others.

Every angler should, himself, look after the welfare of his tackle, and not trust it to the care of guides, hoatmen, or servants. Every true angler should do this. con amore. as every true sportsman should. himself, clean his gum and feed his dogs at the close of a day's shooting, or every true sailor, himself. snug and stow his hoat when the anchor is dropped. As a good workman is known by his jealous care and skillful use of his tools. so is a good angler known by the way he uses and handles his tackle, a good sportsman by the way he uses and handles his gun and dogs, and a good sailor by the way he uses and handles his boat. It is, therefore, essential that the new hand should know the right way, to aroid the wrong way; not only on the score of the fitness of things. but on the score of economy. for more tackle is hopelessly ruined by a lack of proper care, than by the most severe, though judicious, use. 


\section{Care of the Rod.}

The right way to "joint up," or put a rod together, is to take the joints. or pieces. from the case, remove the plugs, or stoppers, and put them in the pocket; then attach the reel to the butt. and see that it fits fimly and securely. and will not be likely to work loose; next wipe the male, or inside ferrules ol the joints. to insure their being dry. (lean, and bright. and rub them on the hair, or with a rag, with a little vaseline or tallow on it, to prevent the ferrules sticking; then the tip and second piece are to be put together first, and the lutt last. Be particular in "jointing up)," to plare the stancling guicies, or rings, in a straight line with the reel (there are nstally small marlis or punetures on the male and fromale formules as a guide), and in fitting the joints, (lo so by inserting the smaller, or male ferrule into the laterer. or female ferrule, and push homes firmly, lut gently, and lo rery calrelul to avoid a twisting, or serewing motion. especially with split-bambon rods, for this is not only liable to warp the forrules. lunt also to separate the strips of such a roul. Alter the rod is properly jointed up. plater the hutt end carefully on the ground, leeve the line through the guides, or rings, and bring it down and tie it to one of the hats of the reel by a single? bow-knot. until reacly to attach the cast of flies. or the swivel and hook.

The wrong way to joint up a rod, and I will describe it as I have seem it Anne, many times, is to put the butt and second piece togrether first; then denp the butt end on the ground and shore it to one side. or behind you, and then put the tip on, the rod swaying and bending, in the meantime, rendering this somewhat difficult to do, but which is finally accomplished ly twisting or serewing it on, the hutt boring a hole in the ground, the while; and 
in case no one has stepped on your rod (which I have seen done more than once), hold the rod perpendicularly, and settle the joints by tamping the butt-end on a stone, or piece of wood. The reel is yet to be adjusted; to do which you may either rest the tip on the ground in front (using it as a boring instrument in this instance), or hold the rod horizontally with the butt against the pit of the stomach, to the great danger of some one stumbling over your rod, or of your striking it against a tree or rock while endeavoring to ship your reel; and yet I have seen this very scene played over and over again by those who called themselves anglers. To hold the rod across the body, sitting or standing, or perpendicularly, while adjusting the reel, is just as awkward and unsafe.

Remember, then, to remove the plugs and put them in the pocket; you will have them then whenever you unjoint your rod, for the separated joints should never be left a moment without the plugs in the female ferrules; in this way you will preserve the proper shape of the ferrules. and your rod will always go together and come apart easily, provided you keep them clean and smooth. Then, ship the reel; then put the smaller joints together first, and the butt piece last.

The right way to "unjoint," or take apart, the rod (I will spare the reader the infliction of a description of the wrong way) is first to remove the leader, or swivel and hook, reel the line on the spool slowly - I say slowly, for I have seen the tip of a rod snapped off while the wet line was being reeled rapidly, or in a hurry, by its catching in one of the rings, or clinging in a coil around the tip. The reel may next be unshipped, and the rod wiped perfectly dry; all sand, dirt, or fish-scales must be carefully rubbed off, and especially must the ferrules be ren- 
dered clean and bright, to prevent any foreign substance getting into them when the rod is being unjointed, for the smallest particle of grit or sand may spoil the fitting of the rod. The rod must now be taken apart in the reverse order in which it was put together; the butt first, and the smaller joints last; in unjointing, pull the joints apart by using gentle and steady force, in a straight line, with the hands close to the ferrules, when they will separate readily. Be particular about this, for I have seen an angler with the joint against his breast. his hands widely separated, pulling on the two pieces in a curred line, as if he would bend the rod around his body, which proceeding had a greater tendency to strain and warp the ferrules than to separate them.

Having taken apart the joints of the rod, the plugs are next to be inserted, and the reel unshipped. Examine each joint. or piece, and if bent, or warped, straighten it carefully, and place them in the case. large end down; in tying the case, tie it loosely, otherwise you may bend the small joints. Never put your rod away in a damp case; should it he wet, dry it thoroughly after reaching home.

When the rod is put together, never stand it in a corner, or lean it with the tip resting against any thing: better lay it down flat. In putting a rod away after the season, it should be laid on a shelf. or in a flat box. It should be kept in a cool room. of uniform temperature, and never in a room heated by a furnace or a stove. A dry atmosphere will cause the joints to shrink, and the ferrules to become loose, while a damp, or constantly changing atmosphere will cause them to twist and warp. The wrapping: of the guides, rings, or hand-piece should be frequently looked to, when in use, and the rod should be rarnished once or twice during the season. Coach varnish is good, 
but the best, perhaps, is a saturated solution of shellac in alcohol; it should be put on quite thin and evenly, and one or two coats applied as may be needed, using a soft rag or sponge; it soon dries and is perfectly waterproof. In Izaak Walton's day rods were painted, and he gives minute directions for preparing the sizing, the paint, and the manner of applying them. Wood, to preserve its elasticity, must be protected from the changes of the atmosphere.

\section{Care of the Reel.}

A fine reel should receive as much care as a watch, so far as this can be done, consistently, with its use. It should never be laid on the sand or bare ground, or exposed in any way to favor the introduction of sand or grit into the working parts. When not in use it should be kept in a box, or in a buckskin or chamois bag. At the beginning and end of each season it should be carefully taken apart, cleaned and oiled. After use; it should be always wiped clean, and rubbed with an oiled rag or chamois skin.

A first-class reel will last an angler his life-time, with proper care. Especially is a multiplying reel to be well cared for, as it is more complicated, and has more gearing than a click reel. The screw that holds the movalble handle to the crank should be frequently noticed, to see that it is firmly screwed in, otherwise it may come out in casting, and both screw and handle be lost. On this account, this screw should never be oiled. The drag, alarm, click, or by whaterer name the "brake" of a multiplying reel may be known, should be used only when really necessary, and as seldom as possible, for its frequent use wears out the gearing of the reel.

See that the reel fits your rod perfectly and tightly, so there will be no shaking, wabbling or coming loose during 
a severe strain. If the reel-plate fits the rod too loosely, place strips of parchment or card-board between the plate of the reel and the groore of the rod, until the reel-band will just slip over the plate and hold it firmly. If the reelplate is too long, or too thick for the reel-seat of the rod, one or the other, or both, must be cut to fit; at all erents, see that your reel fits its seat firmly and securely.

Always, if you can, use the reel "underneath," with the liandle to the right side, when reeling the line; and always turn the crank, in reeling, "away" from you, or in the direction that the hands of a watch move. It may seem unnecesiary to mention this latter precaution, but I have known it to be used the contrary way. When angling, and the fly or bait is in the water, never, for a moment, lay the rod down with a turn of the line around the crank of the reel to serve as a drag, for I have several times seen both rod and reel jerked overboard, and irretrievably lost, by just such inexcusable carelessness and stupidity, ant the savage "bite" of a big fish.

\section{Care of the Line.}

The line should be thoroughly dried, always, after use. This injunction is of the highest importance to the angler. The entire line - not merely the portion that may have been used - should be stretched between two trees, around pess or nails driven up for the purpose, or wound on a line drving-reel, and exposed to the sun and air; or, if at night, or if the day be damp), it should be coiled around the back of a chair, and placed near the fire. I can not impress the necesity of this care too strongly on the beginner, for he will see so many bad examples in those who ought to know hetter, but who habitually put away the reel and wet line, to the everlasting injury of both, because it is "too much 
trouble," or they are "too tired," to perform their bounden duty of drying their lines; such men are "pot-fishers," and will stand their rods, jointed, up in a corner all night. They are on a par with the " pothunter" who, after a hard day's tramp, permits his dogs to go supperlesis to hed, and his gun to remain foul until morning.

Silk lines are especially liable to mildew and rot if put away damp or wet. Eren waterpronf lines should have a good airing after use, or they will retain more or lesis (lampness which in the end will work their destruction. After ärying a line it should be rubbed or reeled through a woolen eloth to remove any sand, grit or mildew. The economy of this whole matter is one thing, and its expediency another; the value of a line may be a small affair, but the breaking away of a gool fish through a defective line is a serious event. I once knew a good fellow, but a poor angler, who, after a day's fishing, carefully dried a fifty-cent handlierehief for four it would mildew, while he left a three-dollar line, wet, on a twentydollar reel and a thirty-dollar rod, standing in the corner all night, because he was "going a-fishing again in the morning."

The line should be thoroughly tested at the beginning of the season, along its whole length; and, if not found fully up to the standard, should be rliscarlerl. It shoul:l also be tested. oceasionally, during the season; in fact, the better way is to test it always before using it. I line that will sustain a dearl weight of two pounds is strong enough, if used with a pliant rod. and no other should be used for black bass angling. By examining and testing the line, always, before using it, it may sare much mortification and many a fish. Though you can not lose a fish by the breaking of the line - for as Father Izaak says, "no 
man can lose what he never had "- you can lose your temper under such trying circumstances, which is worse.

It would be useless to give any directions for waterproofing lines, for it is a very difficult thing to do well; and, moreover, prepared lines are now so cheaply and well made that it will pay the angler to buy them, if he needs waterproof lines. If a line loses its color or tint, it can be soaked in strong green tea, or a weak solution of indigo, to be well-dried afterward. The take the kink, so far as it ean be done, out of laid or twisted lines, let them out their full length and draw them loosely through the water, without hook or sinker. from the stern of a boat as it is rowed along. or orer the lawn. to be then stretehed and dried. Never use a reel-line with a linot in it; better. by far, make some boy hapuy by giving it to him to catch perch and "sunnies."

\section{CARE OF OTHER TACKLE.}

Artificial flies should he closely looked after, summer and winter. to preserve them from their worst enemy - the moth. When put away for the winter. see that the flyhook, or other receptacle. is perfectly clean; dust out the leaves and pockets before putting the flies in. See that the flies are perfect in feather and snell; reject all that are much worn or seem moth-eatem, and those which have worn, frayed or otherwise imperfect snells. Place patchouly, or gum campliner. wrapped in paper, in the pockets and between the leares, and inclose the whole, securely, in cotton cloth.

Leaders should be carefully looked to, and only those that are perfect retained. Imperfect ones may be utilized for snells. Hooks slonld be kept sharpened, and free from rust; it is a good plan to wipe them, after use, with an 
oiled rag; those that are rusted should be thrown away. All tackle, in short, should loe kept neat and clean. It is a great pleasure to the angler to overhaul his tools and tackle several times during the winter, to see that every thing is all right. A little attention to these details, and a following of the advice given in this chapter, will more than repay the angler for the price of this book, and may inculcate habits of order and economy in the novice which will certainly promote his pleasure and happiness. and may save him many a dollar if applied to other wallis in life.

\section{PARTING WORDS.}

IF this book should be the means of making a single day happier in the life of any angler, or of making some crooked things straight to the young hand, or of saring the life of one bass that might have been otherwise killed by illegitimate means or sacrificed to unworthy motives. I shall be glad that it is written; for these considerations alone, and not for any personal profit or aggrandizement has it been penned.

And though there have been rods, and reels, and line: and other articles of tackle named for me by enthusiastic friends, the honor itself has been my only and sufficient recompense, for I assure the reader that I have never received, and would scorn to accept, any pecuniary fee or reward for any thing devised by myself, or made prominent by my efforts, for black bass fishing.

My sole aim and intention has been to elevate the black bass as a game-fish, and to provide suitable tackle for its pursuit and capture, and to inculcate a more healthful and humane and gentlemanly spirit among anglers. 
If I have succeeded, in the slightest degree, my work has proved, as Walton said of angling, "like virtue, a reward to itself."

And now, in taking leave of the angler, or of him who has mentally resolved to become an angler, and who has followed me through the pages of this book, I do so with regret; for it has been to me a labor of love to describe, in my way, the methods and the delights of angling. It has revived the memory of many happy days, spread orer many years of checkered sunshine and shadow. The bright pages in the book of memory stand out like the flashing stream in the bright sunlight, while the sorrows are hid in the deep shadows of its thickly-wooded glens.

"With thee conversing I forget all time." I live, again, in seenes forever past. but never to be forgotten; with rod and reel, again I wander along the upland streams, among the cedars and chinkipins, and on the tide-waters and saltmarshes of "My Maryland;" on Long Island's sea-girt shore; on the lroad bosom of the St. Lawrence, with its thousand emerald isles, and on the charming lakes of the Empire State: among the low green hills of "the valley." the broom-sedge of the "Piedmont" section, and on the broad bays of the "Old Dominion;" in the coves and bights of the stormy Huron, the treacherous Michigan, and the great inland sea. Superior, with its erystal waters, and great hills (rowned by the scarlet hanners of the mountain ash: by the pine-clad rivers of the "Old Nortl State;" along the rocky streams of Kientucky and Tennessee, fleckerl with the roseate tassels and snowy disks of the redbud and dogwood; among the moss-covered rocks of the highland rapids, and under the fragrant magnolia and feathery cypress of the silent estuaries of the "Palmetto State" and Georgia; on the clear, sparkling lakelets 
of Wisconsin, glinting and dancing amid fields of golden grain and broad green pastures, or hiding in sheltered nooks among the tamaracks and hack birches; on the broad Susquehamna, the blue Juniata, and among the hemlocks and maples of the Pennsylvania hills; under the moss-draped live-oak and stately palm, anid the orangegroves and myrtles, the mangrove and sea-grape. on the sluggish streams. the broad lagoons, and along the coralreefs and sumny keys of Florida; under the cool beeches and broad sycamore, the graceful elms and lofty cottonrood of the quiet streams of Ohio, Indiana. Illinois and Missouri; in the cold, crystal streams. gliding among the crerlasting hills, clothed with tangled forests of balsam and pine, in Michigan. It has taken me back even to the days of lang syne, when, with a bit of cock's hackle, tied on a pin-hook, and a willow wand for a rod. I first essayed the angler's art, and made sad haroe among the minnows, chubs and "gudgeons."

I can only hope that the reader may experience a tithe of the pleasure in perusing the foregoing pages, that I have done in penning then ; and he will please remember, that, though he may differ with me on each and every page. I will not quarrel with him; but, should we ever meet, as brothers of the angle, in some sequestered spot on lake or stream, we will, while smoking the pipe of peace, talk the matter over coolly, calmly and dispassionately. But he may rest assured, that, though all roads lead to Rome. and though there are many ways of catching a hass - I have traveled some of the roads, and tried most of the ways - if he faithfully follows in my footsteps. I trust he will never regret it, and never have cause to wish he had tried the other way. 
And now I leave you, with this injunction; and, though I have mentioned it before, I do so at parting, that it may be the more impressive:

ALWAYS KILL YOLF FISII AS SOON AS TAKEN FROM THE WATER; AND EVER BE SATISFIED WITH A MODERATE CREEL.

By so doing your angling days will be happy, and your sleep undisturbed; and you, and I, and the fish we may catch, can say, with the sweet singer of Israel:

"The lines are fallen to me in pleasant places."

It is with a sad leart, and an unwilling pen, that I now finish the concluding chapter of this book, for I feel that it is the last that will ever be added to it.

There is not much likelihood of there being any occasion for adding any thing to it during my life. and it is not at all likely that any one will add any thing to it after I am gone:

I feel like one who is making his last cast on a favorite pool that he will see no more forever. I pool that is endeared to him by the fondest associations. A pool whose coery ripple is a smile. whose erery changing mood is a look of gladness and delight, and whose steadily flowing current seems to beckon him to follow to

"The undiscovered country, from whose bourn No traveler returns." 


\section{INDEX}

TO

\section{SCIENTIFIC HISTORY OF THE BLACK BASS.}

Acanthopteri, 26.

Agassiz, Louis, 17, 18.

Aplesion, 27.

Aplites, 26.

Baird, Spencer F., 10.

Podianus, 26.

Bodianus achigan, 5, 26, 32, 36 .

Bose, M., 4, 15, 16, 18, 24.

Calliurus, 21, 26.

Calliurus punctulatus, 5, 26, $32,36$.

Centrarchidæ, 26.

Centrarchus, 27.

Centrarchus fasciatus, 9, 27, $32,37$.

Centrarchus obscurus, 9, 32, 38 .

Chronological catalogue, 32 .

Cichlidx, 27.

Cichla, 27.

Cichla fasciatus, $6,17,27,32,37$.

Cichla floridana, $6,32,42$.

Cichla minima, 6, 32, 37 .

Cichla ocellaris, 27.

Cichla ohiensis, 6, 32. 37 .

Cichla variabilis, $6,18,32,36$.

Contrasted differential characteristies, 29.

Cope, Edward D., 10, 16.

Cuvier, Baron, 6, 13, 18, 20, 21.

Cuvier \& Valenciennes, 6, 14, 19.

De Kay, James E., 9.

Differential characteristics, 29.

Dioplites, 27.

Dioplites nuecensis, 10, 11, 32, 44.

Dioplites salmoides, 11, 32, 41 .
Dioplites treculii, 11, 32, 44.

Dioplites variabilis, $11,32,36$.

Dolomieu, 21, 22, 38 .

Dolomieu, M., 5, 20, 22, 38 .

Etheostoma, 27.

Etheostoma calliura, 5, 27, 32, 36.

Garden, Dr. Alexander, 4.

Garlick, Dr. Theodatus, 10.

Generic characteristics. 28.

Gill, Dr. Theodore, 10, 13.

Girard, Dr. Charles, 10.

Goode, Dr. G. Brown, 11.

Grystes, 9, 13, 21, 27, 28.

Grystes fasciatus, $17,32,37$.

Grystes megastoma, 10, 32, 44 .

Grystes nigrieans, 10, 17, 32, $38,42$.

Grystes nobilis, 10, 32, 42 .

Grystes nuecensis, 10, 32, 44.

Grystes salmoeides, 37.

Grystes salmoides, 6, 9, 10, 14, $15,17,32,37,41$.

Grystes salmonoides, 32, 37.

Guinther, Dr. Albert C. L. G., 13.

Holbrook, Dr. John E., 9, 10, $16,17,18$.

Huro, 13, 27, 28.

Huro nigricans, 6, 9, 14, 27, $32,42$.

Jordan, Dr. David Starr, 11, $13,14,15,19$.

Kirtland, Dr. Jared P., 9.

Lacepédè, Count, 3, 4, 5, 15 , 1S, $19,20,21$.

Labre salmoïde, $4,6,24,36$. 
Labridæ, 26.

Labrus, 26.

Labrus auritis, 26.

Labrus irideus, 27.

Labrus mixtus, 26.

Labrus salmoides, 4, 12, 14, 15, $17,18,19,20,26,27,32,41$.

Lepomis, 26, 27.

Lepomis achigan, 10, 32, 36.

Lepomis flexuolaris, $5,27,32,36$.

Lepomis notata, $5,32,36$.

Lepomis pallida, 5, 27, 32, 42 .

Lepomis salmonea. 5, 27, 32, 36 .

Lepomis trifasciata, $5,32,36$.

Linnæus, 4.

Microptère dolomieu, le, 22, 26. 28 .

Micropterinæ, 26.

Micropterus, 5, 11, 20, 21, 26, 27. 28.

Micropterus achigan, 10, 32, 38.

Micropterus dolomiei, 35 .

Micropterus dolomieu. 5, 6, 11, $14,15,18,19,20,32,33,35$.

Micropterus dolomieu, synonomy, 35.

Micropterus fasciatus, 32,37 .

Micropterus floridanus, 11, 14, 32. 42.

Micropterus nigricans, $10,32,42$

Micropterus, nominal species, 32 .

Micropterus nuecensis, 11, 32. 44.

Micropterus pallidus, 11, 12, $32,42,43$.
Micropterus salmoides, 10, 11, $12,14,18,32,37,38,39,41$, 42.

Micropterus salmoides var achigan, 11 .

Micropterus salmoides var salmoides, 11.

Micropterus salmoides, synonomy, 41.

Micropterus salmonoides. 42.

Micropterus, synonomy, 26.

Micropterus, synopsis of species, 31.

Micropterus variabilis, 11,32 , 36.

Milbert, M., 6.

Nemocampsis, 27.

Rafinesque, C. S., 5, 14.

Rhegnopteri, 26.

Salmoides. 21.

Scientific history of the black bass, 3 .

Serranidæ, 26 .

Synonomy and references of Micropterus, 26.

Synonomy and references of M. dolomieu, 35 .

Synonomy and references of II. salmoides, 41.

Synopsis of species of Micropterus, 31.

Teleostei. 26.

Vaillant, Dr., 14, 18, 21.

Vaillant \& Bocourt, 11, 12, 13.

Valenciennes, M., 6. 


\section{Index to Life History and Angling.}

Aerating water, 270.

American silk-worm, 219.

Argling, as a recreation, 316 .

as an art, $311,312,313$.

best season for, 326 .

conditions for, 326 .

effect of wind on, 326, 328.

perfect day for, 331 .

philosophy of, 307 .

pleasures of, $313,314,315,318$. uncertainty of, 317 . youthful, 411.

Artificial baits, 258.

Artificial flies, 243, 254.

care of, 440.

hackles, 246, 248.

hooks for, 247.

Japanese, 257.

list of, 250, 251, 253, 253, 255, 256.

rules for, 245.

successful, 248.

table of, 249 .

winged, 246.

Artificial insects, 266.

minnows, 265.

A reminiscence, 380 .

A retrospection, 416 .

Ash, for rods, 129.

Au revoir, 444.

Bag, camping, 301.

Baits, 258.

bob, 268.

insects, 266.

mouse, 266.

natural, 268 .

spoons and spinners, 258.

Bait-fishing, 385 .

bobbing, 429 .

casting the minnow, 385 .

skittering, 428.
Bait-fishing - Continued. still-fishing, 411 . trolling, 420 .

Bait lines, 205, 206, 213, 214.

Bait rods, 145 .

Baits for still-fishing, 414.

Bamboo, Calcutta, 130.

Baskets, fish, 280, 281. slings, 281.

Bethabara for rods, 130 .

Biting of fish, 316. conditions which govern, 317.

Black bass as a game-fish, 338 . voracity of, 348 .

Boats, 301, 302.

Bob, 266, 267.

Bobbing, 429.

tackle and method, 430, 431. in Florida, 431.

Boots, rubber, 299.

Buckets, minnow, 286, 287.

Caliper, gauge, 298.

Camping bag, 301.

Cane for rods, 130.

Capture of the bass, 351, 352, 353, 354.

Care of minnows, $270,271$.

of tackle, 433,440 .

of flies, 440.

of leaders, 441 .

of lines, 438 .

of reels, 437 .

of rods, 434 .

Cases, rod, 300. reel, 300.

Casting lines, 219.

Casting the fly, 365 .

method of, $366,367,368,369$.

overhead, 368 .

sidewise, 369.

switch cast, 370 . 
Casting the minnow, 385 .

casting to left, 394.

casting to right, 395 .

general instructions, 400, 403.

longest casts, 390,391 .

making the east, 393, 398, 399 .

management of hooked fish, 403, 404,407 .

rigging the east, 393 .

tackle for, 387, 391, 392.

Cecropia silk-worm, 218.

Cells, pigment, 55, 56, 62.

Clearing rings, 294.

Click reel, 176 . construction of, 176,177 .

Coloration of black bass, 53 .

causes of, 55 .

changes in, 54 .

inconstancy of, 55 .

influence of age, 60 .

influence of breeding, 61 .

influence of environment, 62 .

influence of food, 56 .

influence of light, 60.

influence of season, 59, 61 .

influence of water, 59.

involuntary, 62 .

voluntary, 63.

Colorists, 244.

Coming bass rod, 148.

Concluding remarks, 433.

Conditions governing biting of fish, 316.

change of location, 324, 325.

condition of water, $320,321,324$.

electricity, 336.

fear of enemies, 321.

hunger, 319.

influence of moon. 330.

of rain, 333,334 .

of season, 326 .

signs of the zodiac, 330 .

state of atmosphere, 326 .

state of wind, $32 \pi, 328,329$.

time of day. 335 .

thunder, 336.

Corks, 287, 289.

Corydalis, $271,272$.

Crawfish, 273, 414.

live-box for, 287 .
Creels, 280.

Crickets, 274, 414.

live-box for, 287.

Culture of black bass, 79 .

Diflerences, specific, 45 .

Disgorgers, 295.

Distribution, geographical, 64 .

by transplanting, 67 .

effect of climate on, 65,66 .

effect of food, 67 .

of physical features, 65 .

of waters, 66 .

original habitat, 65 .

Do fishes sleep, 110.

Drag handle, 188.

Drver, line, 297.

Extractor, hook, 295.

Feeding and fasting of fish, 320,322 , 323.

Ferrules, rod, 161, 162, 163, 173.

Fish baskets, 280, 281.

Fish hooks, 230, 234, 236.

Aberdeen, 232.

ancient, 230.

barbless, 237 .

Carlisle, 232.

English, 230.

eyed, 237, 238, 239.

Japanese, 235.

Limerick, 232.

O'Shaughnessy, 232.

Redditch, 231.

sproat, 312.

system of numbering, 239 .

Fishing lines, 205.

Fishing reels, 174, 183.

Fishing rods, 127 .

essential qualities, 127.

material for, 129.

Flies, artificial, 243, 254.

hackles, 246.

hooks for, 247.

lists of, $250,251,252,253$.

palmers, 246.

rules for, 245 .

successful, 248.

table of, 249.

winged, 246.

Floats, 288, 289.

Fly-books, 276, 277, 278. 
Fly-boxes, 278, 279.

Fly-fishing, 357.

casting the fly, 361 .

hints and advice, 360, 362, 374, $375,376,379,380$.

literature of, 359 .

on lakes, 362.

on streams, 361.

pleasures of, 358 .

rules for, 377,378 .

where to cast, 379 .

Fly-lines, 210, 212, 213.

Fly-rods, 167, 168, 169, 170, 171.

Henshall, 172.

Food and growth, 80.

Food of black bass, 80 .

of adults, 80,81 .

of young, 80,81 .

S. A. Forbes on, 80 .

Formalists, 244.

Frogs, 274, 414.

live-box for, 287.

Frog-casting rod, 166.

Gameness of black bass, 50, 338, 340 . opinions on, $339,342,344,345$.

Gauge, caliper, 298.

General and specific features, 45.

Geographical distribution, 64.

Gogebic Lake, 425.

Grasshoppers, 274, 414.

live-box for, 287.

Greenheart for rods, 129.

Growth of black bass, 82 .

in Florida, 86, 87.

in New Jersey, 83.

in New York, 83, 84 .

in Ontario, 85, 86.

in the north and west, 82 .

in the south, 82 .

in Wisconsin, S3.

Gut, silk-worm, 216, 217, 218.

Habits of black bass, 74 .

food and growth, 80 .

guarding eggs and fry, ' 76 .

hibernation, 87, 90.

nesting, 75,78 .

spawning and hatching, 74,75 , 76.

Habitat, 50, 64, 65, 66 .

Hackles, 246, 248.
Hand-line trolling, 423.

tackle for, 424 .

instructions for, 425 .

Hatehing, 74, 76.

Hearing, sense of, 100, k01.

B. B. Redding on, 103, 104 。

Dr. Edw. D. Cope on, 104.

Dr. J. Zenneck on, 107。

H. G. Parker on, 105, 106.

Sir Herbert Maxwell on, 108.

Helgramites, 271, 414.

live-box for, 287.

Henshall bait rod, 132, 149, 150, 151, $154,157,338,389$.

ash and lancewood, 151, 156.

bethabara, 155 .

specifications for, 151, 152, 153, 155.

split-bamboo, 155.

steel, 166.

Henshall fly-rod, 172.

specifications for, 173.

Hibernation, Sī, 90.

in Lake Erie, 91.

in Minnesota, 88.

in New York, 88, 89.

in West Virginia, 89.

in Wisconsin, 87 .

Hook extractors, 295.

Hooks, 230, 234, 236.

Aberdeen, 232.

ancient, 230.

barbless, 237.

Carlisle, 232.

English, 230.

eyed, 237, 238, 239.

Japanese, 235.

Limerick, 232.

O'Shaughnessy, 232。

Redditch, 237.

Sproat, 232.

system of numbering, 239.

Hooks, tying to snells, 241 .

Ideal still-fisher, 409.

Implements, miscellaneous, 276 .

Insects, artificial, 266.

Intelligence and special senses, 92.

Dr. Francis Day on, 92。

hearing, 100 . 
Intelligence and special sensesContinued. sight, 93 .

smell, taste and touch, 109.

Introduction of black bass in Massachusetts, 68.

in Connecticut, 68.

in England, 114, 117.

in Germany, 118, 119.

in Holland, 119.

in Maine, 69.

in Maryland, 69.

in New Hampshire, 68.

in New York, 68.

in Pennsylvania, 69 .

in Rhode Island, 69.

in Scotland, 119.

in Virginia, 69.

Instructions for casting the fly, 372 . for bobbing, 429 .

for casting the minnow, 393.

for skittering, 428.

for still-fishing, 415,416 .

for striking and playing, 373 .

for trolling, 423, 424 .

Jam knots, 239.

Japanese flies, 257.

Kendal hook scale, 239.

Kentucky reel, origin of, 183.

Knife and screwdriver combined, 297.

Knots, 225, 228.

becket hitch, 226.

common, 226.

for tying leaders, 229.

invisible, 242.

jam, 239.

loop, 226.

reef, 227.

tiller hitch, 226.

water, $226,227$.

Landing-nets, 281, 282, 283.

Leaders, 219.

eare of, 441.

color for, $220,221$.

loops for, 222.

testing, 223 .

tying, 223.

Leader-boxes, 278, 279.

Level-winding reels, 187.

Line dryer, 297.
Lines, 205.

bait-casting, 205, 207, 208.

care of, 438, 439 .

dressed silk, 206, 209, 212.

enameled, 210.

fly, 210.

hair, 21 ?.

linen, 207, 211.

metal-center, 213.

raw silk, 205, 209, 212.

sea-grass, 214.

tapered, 211.

trolling, 215 .

twisted silk, 213.

waterproof, 212.

Little giant rod, 163.

specifications for, 165 .

Live-box, 287.

Markings of black bass, 54,55 .

Meek, B. F., portrait of, 198.

Metal-centered line, 213.

Milam, B. C., portrait of, 199.

Minnow-buckets, 286, 287.

Minnow-nets, 283, 285.

Minnows, 268, 414, 416.

artificial, 265.

eare of, 270.

how to bait with, 269 .

natural, 268, 269.

phantom, 265.

preserved, 271.

Minnow-traps, 284, 285.

Miscellaneous implements, 276.

Mouse as bait, 266 .

Multiplying reels, 179. construction of, $179,180$.

Names, vernacular, 50. confusion of, 51 . distinctive, 52 .

Natural baits, 268. crawfish, 273.

crickets, 274 .

frogs, 274 .

grasshoppers, 274.

helgramites, 271.

minnows, 268.

shrimps, 275.

Nets, landing, 281, 282, 283. minnow, 283.

Non-dowel joint, 160, 162. 
Old time rods, 146.

Origin of black bass fishing, 190 . of Kentucky reel, 189.

of split-bamboo rod, 134 .

Falmers, 246.

Pants, wading, 299.

Parting words, 441.

Phantom minnows, 265.

Phillippe, Samuel, portrait of, 135.

Philosophy of angling, 307.

Pigment cells, 55, 56, 62.

Pilot, 263.

Playing a bass, 273.

Pond cuiture, 79.

Portrait of B C. Milam, 199.

of B. F. Meek, 198.

of Samuel Phillippe, 135.

of J. L. Sage, 202.

Pot-fishers, 426.

Pot-hunters, 426.

Potomac river, stocking of, 69 .

Baltimore American on, 72 .

Edw. Stabler on, 71.

John Eoff on, 70.

W. W. Shriver on, 70.

Preserved minnows, 271 .

Range of black bass, 46,64 .

Redditch scale for hooks, 239.

Reel, care of, 437.

Reels, 174, 183, 185.

click, 176.

drag-handle, 188.

epicycloidal, 201.

Kentucky, origin of, 183.

level-winding, 187.

wooden spool, 201.

Reel cases, 300 .

Reminiscence, a, 380 .

Retrospection, a, 416 .

Rigging the cast, 363, 364 .

Rings, clearing, 294 .

Rod, care of, 434, 436.

jointing and unjointing, 435 .

Rod cases, 300 .

Rods, 127.

ash and lancewood, 151.

bait, 145 .

bethabara, 155

cedar, 128.
Rods - Continued.

coming bass rod, 148 .

fly, 167 .

frog-casting, 165.

Henshall, 132, 134.

improvements in, 131 .

little giant, 163 .

materials for, $128,129,130$.

mountings, 161, 164 .

old time, 146.

steel, 166.

typical, 149.

Rubber boots, 299 .

Rules for flies, 245.

Sage, J. I., portrait of, 202.

Screwdriver and knife, 297.

Shoes, wading, 299.

Shrimps, 275.

Sight, sense of, 93, 94, 95, 96, 97, 98, $99,100$.

Silk lines, 205, 206.

Silk-worm gut, 216. native, $217,218$.

Single-hook spoons, 261, 262, 263, 264.

Sinkers, 290, 291.

Skittering, 42. .

tackle and instructions, 429.

Sleep, do fishes? 110.

Slings, baskets, 281.

Smell, sense of, 109.

Snelling hooks, 240 .

Snells, 224.

gut, 224.

gimp, 224.

Snoods, 224.

Snyder, George, inventor of Kentucky reel, 191.

his gaff-hook, 204.

Sparvning, 74.

in Florida, '77。

in Ohio, 77 .

Specific differences, 45 。

Fred Mather on, 49.

in Arkansas, 45.

in color, 46,47 .

in fins, 47,48 。

in Florida, 45 .

in mouth, 48 .

in scales, 48 . 
Specific differenees - Continued.

in Texas, 45.

in Wisconsin, 57 .

Split-bamboo rods, 133, 155.

in England, 138.

origin of, $13 \mathrm{~s}$.

round and hexagonal, 143, 144.

Spinners, weedless, 264.

Spoon-baits, 258.

Spoons, trolling, 258, 259, 260.

original, 258.

single-hook, 259.

triple-hook, 259, 260,261，262, 263.

Standard Henshall rod, 154, 156, 157.

Steel rod, 166.

Still-fisher, the ideaI, 4ĩ2.

Still-fishing, 411 .

baits and baiting, 414 .

instructions, 415,416 .

tackle, 413.

Stocking waters, 68, 69, 111, 112, $113,114$.

transportation, $115,116,117$.

Striking, 373.

Sumny days of youth, 412.

Swivels, 291.

Takkle-books, 279, 280.

Tackle for bait-fishing, 387 .

for fty-fishing, 363 .

for trolling, 421.

still-fishing, 413.

Take-apart reels, 182, 184.

Tapered lines, 211.

Taste, sense of, 109.
The capture of the bass, 351.

Tools, tackle and implements, 123.

Touch, sense of, 107, 109.

Transportation of bass 115, 116, 117.

Traps, minnow, 284, 285.

Trolling, 420.

instructions, 423.

tackle for, 421, 422, 424 .

with hand-line, 424.

with the rod, 420 .

Trolling baits, $25 \mathrm{~s}$.

Trolling lines, 215.

Trolling-spoons, 259.

Trout, brook, decline of, $341,342$. causes of, 346,347 .

Turn-a-frog, 264.

$\checkmark$ enus and Cupid fishing, 125.

Vernacular names, 50.

Wading boots, 299.

pants, 299.

shoes, 299.

Waterproof lines, 212.

Weedless spimners, 264.

Weight, maximum, 85, 86.

Wood for rods, 129.

ash, 129 .

bamboo, 130.

bethabara, 130 .

cane or reed, 130.

greenheart, 129.

lancewood, 129.

Words, parting, 441.

Ye old Kentucky Angler, 306.

Youthful angling, 411.

Ye Sunberry Fisher, 256. 







\section{LIBRARY OF CONGRESS}

